PRICILA HAUK TEODORO

\title{
CARACTERIZAÇÕES BIOLÓGICAS DAS PROTEÍNAS LipL32 E HIyX DE LEPTOSPIRA INTERROGANS SOROVAR COPENHAGENI
}

Tese de Doutorado apresentada ao Programa de Pós-Graduação Interunidades em Biotecnologia USP/Instituto Butantan/ IPT, como pré-requisito para a obtenção do Título de Doutor em Biotecnologia. 


\title{
CARACTERIZAÇÕES BIOLÓGICAS DAS PROTEÍNAS LipL32 E HlyX DE LEPTOSPIRA INTERROGANS SOROVAR COPENHAGENI
}

\author{
PRICILA HAUK TEODORO
}

Tese de Doutorado apresentada ao Programa de Pós-Graduação Interunidades em Biotecnologia USP/Instituto Butantan/IPT, como pré-requisito para a obtenção do Título de Doutor em Biotecnologia.

Área de concentração: Biotecnologia

Orientador: Dr. Paulo Lee Ho 
DADOS DE CATALOGAÇÃO NA PUBLICAÇÃO (CIP)

Serviço de Biblioteca e Informação Biomédica do Instituto de Ciências Biomédicas da Universidade de São Paulo

(C) reprodução total

Teodoro, Pricila Hauk.

Caracterizações biológicas das proteínas LipL32 e HlyX de

Leptospira interrogans sorovar Copenhageni / Priscila Hauk Teodoro.

-- São Paulo, 2009.

Orientador: Paulo Lee Ho.

Tese (Doutorado) - Universidade de São Paulo. Instituto de Ciências Biomédicas. Programa de Pós-Graduação Interunidades em Biotecnologia USP/IPT/Instituto Butantan. Área de concentração: Biotecnologia. Linha de pesquisa: Genoma funcional de Leptospira interrogans sorovar Copenhageni.

Versão do título para o inglês: Biology characterization of LipL32 and HlyX proteins of Leptospira interrogans sorovar Copenhageni.

Descritores: 1. Microbiologia médica 2. Bactérias espiroquetas 3. Leptospira 4. Leptospirose 5. Proteínas recombinantes 6. Proteínas de matriz extracelular I. Ho, Paulo Lee II. Universidade de São Paulo. Instituto de Ciências Biomédicas. Programa de Pos-Graduação em Biotecnologia III. Título. 
Candidato(a):

Título da Tese:
Pricila Hauk Teodoro.

Caracterizações biológicas das proteínas LipL32 e HlyX de Leptospira interrogans sorovar Copenhageni.

Paulo Lee Ho.

Orientador(a):

A Comissão Julgadora dos trabalhos de Defesa da Tese de Doutorado, em sessão pública realizada a

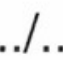
...................., considerou

\section{( ) Aprovado(a) \\ ( ) Reprovado(a)}

Examinador(a): Assinatura:

Nome:

Instituição:

Examinador(a): Assinatura:

Nome:

Instituição:

Examinador(a): Assinatura:

Nome:

Instituição:

Examinador(a): Assinatura:

Nome:

Instituição:

Presidente: Assinatura:

Nome:

Instituição: 


\section{CERTIFICADO}

Certificamos que o Protocolo para uso de animais em experimentação $n^{\circ} 256 / 06$, sobre o projeto intitulado "Desenvolvimento de vacinas contra a leptospirose", sob a responsabilidade de Paulo Lee Ho está de acordo com os Princípios Éticos na Experimentação Animal adotado pelo Colégio Brasileiro (COBEA) e foi aprovado pela COMISSÃO DE ÉTICA NO USO DE ANIMAIS DO INSTITUTO BUTANTAN (CEUAIB) em reunião de 14/03/2006.

São Paulo, 17 de março de 2006.

De acordo:

Dr. Otávio Mercadante

Diretor do Instituto Butantan 
Aos meus avós paternos Helmuth "in memorium" e Otília Hauk pelo amor, apoio e principalmente por SEMPRE apostarem em mim, incondicionalmente. 


\section{AGRADECIMENTOS}

Ao meu orientador, Dr. Paulo Lee Ho pela confiança depositada em mim para a realização deste projeto de pesquisa.

Ao Dr. Shaker Chuck Farah por me ajudar com os estudos estruturais de LipL32. Obrigada pelo tempo dispensado à mim e ao meu projeto de pesquisa.

Ao meu amor Mairan Macedo Teodoro, que tanto admiro, por entender minhas questões, dividir meus anseios, aturar meu imediatismo e por ser tão especial para mim!

Aos meus pais, Vitor e Leatrice Hauk pelo apoio constante durante esta dura caminhada e por entenderem a minha ausência.

Aos meus irmãos, avós e demais familiares por acreditarem no meu potencial.

Às pesquisadoras do Instituto Butantan, Dra. Angela Silva Barbosa e Dra. Patricía Antonia Estima Abreu pelas discussões, pelas dicas, pelos experimentos que me ajudaram a realizar e por serem tão generosas. Quero que saibam que são especiais para mim.

À Dr. Maria Leonor Sarno de Oliveira por me apoiar em momentos difíceis no Laboratório de Biotecnologia Molecular I e me ajudar a realizar e interpretar experimentos realizados com animais.

Ao Dr. Inácio de Loiola Meirelles Junqueira de Azevedo por me ajudar na clonagem do gene hlyX de $L$. interrogans sorovar Copenhageni.

Aos meus amigos, colegas e técnicos do laboratório de Biotecnologia Molecular I e dos demais laboratórios do Instituto Butantan, meu muitíssimo obrigada pela convivência, por me ensinar, discutir protocolos e pelo empréstimo de reagentes e equipamentos.

A todos da Faculdade de Medicina Veterinária e Zootecnia da USP que participaram e ajudaram nos ensaios de imunização e desafio em modelo de estudo animal

A todos os meus professores desde o ensino fundamental até a pós-graduação que levaram a missão de ensinar à sério. Nunca esquecerei dos professores que contribuiram e dos que ainda contribuirão para a minha formação.

À Cristiane Rodrigues Guzzo, por me ensinar e ajudar na resolução da estrutura de LipL32. Obrigada pela amizade e pelo zêlo!

À Sílvia Bazan por ser uma das únicas pessoas que consegue entender como me sinto, provavelmente por nos identificarmos muito, pela lealdade e verdadeira amizade.

À todos os funcionários do Instituto Butantan que foram gentis, prestativos e generosos comigo, pois acho que aprendemos muito uns com os outros, e isto é muito construtivo.

Aos meus colegas do laboratório do prof. Dr. Shaker Chuck Farah, do Instituto de Química da USP por terem me recebido com tanto carinho.

Ao Laboratório Nacional de Luz Síncrotron (LNLS) e seus funcionários pelo serviço prestado.

À Fundação de Amparo à Pesquisa do Estado de São Paulo (FAPESP) pelo apoio financeiro.

Á Fundação Butantan, pela infra-estrutura permitindo o desenvolvimento do projeto. 
"No meio do caminho tinha uma pedra tinha uma pedra no meio do caminho tinha uma pedra no meio do caminho tinha uma pedra" (....) Carlos Drummond de Andrade (em "No meio do Caminho") 


\section{RESUMO}

Hauk P. Caracterizações biológicas das proteínas LipL32 e HlyX de Leptospira interrogans sorovar Copenhageni [Tese (Doutorado em Biotecnologia)]. São Paulo: Instituto de Ciências Biomédicas da Universidade de São Paulo; 2009.

Leptospirose é uma zoonose causada pela espiroqueta pertencente ao gênero Leptospira. LipL32 é um antígeno de superfície altamente conservado somente entre as espécies de leptospiras patogênicas e é expresso em altos níveis tanto in vitro com in vivo. HlyX é relatada como sendo uma proteína que possui um provável peptídeo sinal e cinco tetratricopeptídeos repetidos (TPR) em sua sequência de aminoácidos. Neste trabalho, mostrou-se que HlyX é expressa somente em cepas patogênicas, não sendo detectada a sua expressão na cepa saprofítica. HlyX foi reconhecida somente por soros de pacientes da fase convalescente da doença. Em constraste, LipL32 foi reconhecida por soros de pacientes colhidos tanto na fase aguda quanto na fase convalescente da infecção. Nossos resultados de immunoblot indicam que os domínios imunodominantes da proteína são os fragmentos C-terminal e intermediário. Uma resposta IgM foi detectada exclusivamente contra o fragmento C-terminal de LipL32 em ambas as fases da infecção. Com relação à capacidade de LipL32 e HlyX de interagir com componentes de matriz extracelular (CME), foi observada uma interação específica e dose-dependente de LipL32 e HlyX com colágeno tipo IV e fibronectina plasmática. O fragmento C-terminal de LipL32 é responsável por esta interação. Tanto a heparina quanto a gelatina foram capazes de inibir a ligação de LipL32 à fibronectina plasmática de forma dose-dependente, indicando que os domínios de ligação à heparina $(30 \mathrm{kDa})$ e gelatina $(45 \mathrm{kDa})$ da fibronectina estão envolvidos nesta interação. Por outro lado, apenas o domínio de ligação à heparina participa da interação da fibronectina com a proteína HlyX. A capacidade protetora das duas proteínas estudadas foi avaliada através de ensaios de imunização e desafio realizados em modelo animal (hamsters). A proteína HlyX induziu altos títulos de anticorpos IgG (1:128.000), mas somente a co-administração HlyX e LipL32 e a proteína LipL32 pura conferiram proteção, $100 \%$ e $80 \%$ respectivamente. HlyX não foi capaz de conferir proteção quando administrada apenas com o adjuvante $\mathrm{Al}(\mathrm{OH})_{3}$. Em conclusão, os resultados indicam que o domínio C-terminal de LipL32 é reconhecido desde o início da infecção e este domínio é responsável por mediar a interação de LipL32 com CME. Os dados obtidos com HlyX demonstram um possível papel desta proteína na patogênese, pelo fato de ser expressa e conservada em cepas patogênicas, e também por interagir com CME. Porém, apesar de HlyX apresentar altos títulos de anticorpos IgG, não conferiu atividade protetora quando administrada individualmente.

Palavras-chave: Leptospirose. Leptospira interrogans sorovar Copenhageni. Antígenos. LipL32. HlyX. Adesinas. Componentes de matriz extracelular. 


\begin{abstract}
Hauk P. Biology characterization of LipL32 and HlyX proteins of Leptospira interrogans sorovar Copenhageni [Ph.D. thesis (Biotechnology)]. São Paulo: Instituto de Ciências Biomédicas da Universidade de São Paulo; 2009.

Leptospirosis, a spirochaetal zoonotic disease caused by Leptospira, has been recognized as an important emerging infectious disease. LipL32 is a surface lipoprotein which is highly conserved among pathogenic Leptospira species and is also expressed at high levels either during cultivation and natural infection. Regarding HlyX, it has been annotated as a protein containing a signal peptide and five tetratricopeptide repeats (TPR). Immunoblot analyses concerning HlyX distribution on Leptospira spp. indicate that this protein is expressed exclusively by pathogenic species. Moreover, HlyX was only recognized by sera of patients in the second week of leptospirosis infection. In contrast, LipL32 was recognized by acute and convalescent sera from leptospirosis patients. Our immunoblot results indicate that both the C-terminal and the intermediate domains of LipL32 are recognized by sera of patients. An IgM response was detected exclusively against the LipL32 C-terminus in both the acute and convalescent phases of illness. Concerning the capacity of LipL32 and HlyX to interact with extracellular matrix (ECM) components, a dose-dependent specific binding of LipL32 and HlyX to collagen IV and plasma fibronectin was observed. The LipL32 binding capacity could be attributed to the C-terminal portion of this molecule. Both heparin and gelatin could inhibit LipL32 binding to fibronectin in a concentration-dependent manner, indicating that the $30-\mathrm{kDa}$ heparin- and the $45-\mathrm{kDa}$ gelatin-binding domains of fibronectin are involved in this interaction. However, HlyX binding to fibronectin could only be inhibited by heparin in a concentration-dependent manner. We also evaluated whether HlyX and LipL32 could induce protective immunity against the challenge with a homologous serovar in hamsters. Although high anti-HlyX $(\operatorname{IgG})$ titers $(1: 128,000)$ have been achieved upon immunization, no protection was observed. However, a combined HlyX and LipL32 immunization could induce a protective response $(100 \%)$. The protection observed for LipL32 immunization was $80 \%$. Altogether, the results provide evidence that the LipL32 C-terminus is recognized early in the course of infection and is the domain responsible for mediating interaction with ECM proteins. HlyX protein may contribute to the pathogenesis of the disease by interacting with host proteins. However, HlyX is not a protective antigen when administered alone.
\end{abstract}

Keywords: Leptospirosis. Leptospira interrogans serovar Copenhageni. Proteins. LipL32. HlyX. Adhesins. Extracellular matrix components. 


\section{LISTA DE FIGURAS}

Figura 1 - Taxonomia das espiroquetas.

Figura 2 - Comparação entre a arquitetura das membranas de bactérias Gram-negativas e de espiroquetas

Figura 3 - Esquema ilustrando a membrana externa, cilindro celular protoplasmático e o flagelo periplasmático das espiroquetas.

Figura 4 - Leptospiras analisadas por microscopia eletrônica.

Figura 5 - Modelo da exportação de lipoproteínas em espiroqueta..

Figura 6 - Sequência de aminoácidos da LipL32.

Figura 7 - Sequência de aminoácidos de HlyX.

Figura 8 - Representação esquemática dos vetores de expressão em E. coli. 40

Figura 9 - Sequência de nucleotídeos e aminoácidos de HlyX 44

Figura 10 - Sequência de nucleotídeos e aminoácidos de LipL32. 45

Figura 11 - Amplificação dos genes hlyX e lipL32. 60

Figura 12 - Purificação de LipL32 6xHis. 63

Figura 13 - Purificação do fragmento intermediário de LipL32.

Figura 14 - Purificação do fragmento C-terminal de LipL32

Figura 15 - Purificação de HlyX renaturada. 65

Figura 16 - Purificação do fragmento N-terminal de LipL32 66

Figura 17 - Purificação de LipL32, através de cromatografia catiônica (SP-sepharose) e cromatografia hidrofóbica (Phenyl sepharose). 67

Figura 18 - Purificação de LipL32 Se-M, através de cromatografia catiônica (SP-sepharose). 68

Figura 19 - Purificação de LipL32 através de cromatografia hidrofóbica (Phenyl sepharose). 68

Figura 20 - Confirmação da identidade das proteínas purificadas...... 69

Figura 21 - Especificidade dos anticorpos gerados contra os fragmentos de LipL32. 70 
Figura 22 - Pesquisa de anticorpos IgM e IgG gerados contra as proteínas HlyX e LipL32 utilizando soros de pacientes com leptospirose.

Figura 23 - Fragmentos de LipL32 recombinante e a reatividade com soro de camundongos e com soro de pacientes com leptospirose.

Figura 24 - Espectros de dicroísmo circular das proteínas recombinantes HlyX, LipL32 6xHis e LipL32.

Figura 25 - Ligação de LipL32 6xHis e HlyX recombinantes a componentes de matriz extracelular e proteínas plasmáticas.

Figura 26 - Ligação de LipL32 6xHis e de seus fragmentos C-terminal e intermediário em fibronectina plasmática (molécula inteira e seus fragmentos proteolíticos, F30 e F45) e ao colágeno tipo IV em função da concentração de proteínas.

Figura 27 - Ligação de HlyX à fibronectina plasmática (molécula inteira e seu fragmento proteolítico, F30, mas não ao F45) e ao colágeno tipo IV em função da concentração.

Figura 28 - Inibição da ligação de LipL32 aos fragmentos proteolíticos F30 e F45 e ao colágeno tipo IV pelo fragmento C-terminal de LipL32.

Figura 29 - Inibição da ligação de LipL32 aos fragmentos proteolíticos de fibronectina plasmática F30 e F45 por heparina e gelatina, respectivamente.

Figura 30 - Inibição da ligação de HlyX ao domínio de ligação da fibronectina plasmática a heparina. 84

Figura 31 - Títulos de anticorpos IgG gerados contra a proteína HlyX, obtidos em um único experimento realizado

Figura 32 - Títulos de anticorpos IgG gerados contra a proteína LipL32, obtidos em um único experimento realizado. 86

Figura 33 - Títulos de anticorpos IgG gerados contra o fragmento C-terminal de LigA, obtidos em um único experimento realizado..

Figura 34 - Análise da porcentagem de sobrevivência dos grupos de animais vacinados: salina, bacterina, C-terminal LigA, HlyX, LipL32 e HlyX co-adminstrada com LipL32. 88 


\section{LISTA DE TABELAS}

Tabela 1 - Oligonucleotídeos utilizados para a amplificação dos genes hlyX, lipL32 6xHis, lipL32 e seus fragmentos $\mathrm{N}$-terminal, intermediário e C-terminal.

Tabela 2 - Massas moleculares e pontos isoelétricos (pIs) das proteínas recombinates 62

Tabela 3 - Títulos de MAT, início dos sintomas, sorovar infectante, e detecção de anticorpos nas amostras de soros de 12 pacientes com leptospirose.

Tabela $4-K_{d}$ s relativas à ligação de LipL32, do fragmento C-terminal de LipL32 e de HlyX à fibronectina plasmática e ao colágeno tipo IV.

Tabela 5 - Avaliação do desafio animal quanto ao número de animais sobreviventes e a presença de leptospiras no fígado dos animais vacinados (portadores). 


\section{LISTA DE ABREVIATURAS E ACRÔNIMOS}

Amp - ampicilina

AP-1 - Ativador de proteína-1 (fator de transcrição)

BSA - albumina bovina sérica

$\mathrm{Clo} / \mathrm{Cm}^{\mathrm{R}}$ - cloranfenicol/resistência a cloranfenicol

CME - Componentes de matriz extracelular

DNA - ácido desoxirribonucléico

dNTPs - deoxinucleotídeos trifosfato

DO - densidade óptica

ECM - Extracellular matrix components

EDTA - ácido etileno diamino tetracético

ELISA - Enzyme-Linked Immunosorbent Assay (ensaio imunoenzimático)

EMJH - Meio Ellinghausen-McCullough-Johnson-Harris

ExPASy - Expert Protein Analysis

F30 - fragmento proteolítico de fibronectina plasmática purificado que possui $30 \mathrm{kDa}$ domínio de ligação a heparina

F45 - fragmento proteolítico de fibronectina plasmática purificado que possui $45 \mathrm{kDa}-$ domínio de ligação a gelatina

iNOS - Óxido nítrico sintetase induzível

IPTG - isopropiltiogalactosídeo

$\mathrm{kDa}-10^{3}$ Dalton

$k d$ - constante de dissociação

LPS - lipopolissacarídeo

MAT - título de aglutinação microscópica 
MCP-1 - Proteína quimioatraente de monócitos

NCBI - National Center for Biotechnology Information (Centro Nacional para Informação em Biotecnologia)

$\mathrm{NF}-\mathrm{\kappa B}$ - fator-кB nuclear

$\mathrm{pb}$ - pares de base

PBS - Phosphate buffer saline (tampão fosfato-salina)

PBS-T - tampão fosfato contendo tween 20

PCR - Polymerase Chain Reaction (reação em cadeia da polimerase)

$\mathrm{pI}$ - ponto isoelétrico

PMSF - Phenylmethylsulfonyl fluoride

OPD - o-diidrocloreto fenilenodiamina

RANTES - Regulation on activation, normal $T$ cell expressed and secreted

RNA - ácido ribonucléico

SDS - dodecil sulfato de sódio

SDS-PAGE - eletroforese em gel de poliacrilamida com SDS

SMART - Simple Modular Architecture Research Tool

TAE - tampão tris-acetato e EDTA

TLR-2 - Toll Like Receptor Type 2

TNF- $\alpha$ - fator de necrose tumoral $\alpha$ 


\section{SUMÁRIO}

1 INTRODUÇÃO

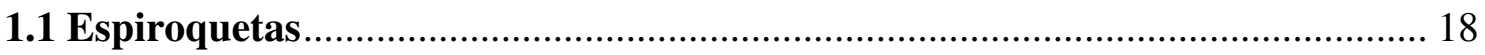

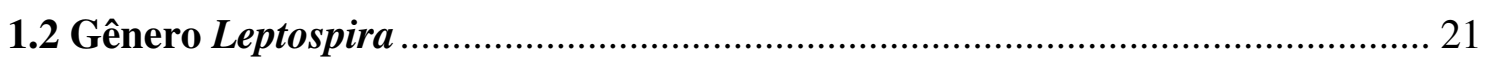

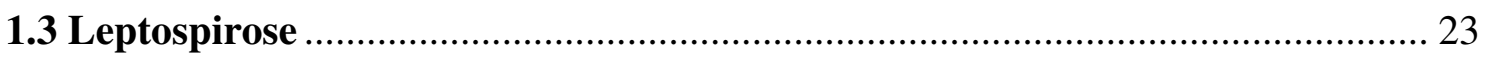

1.3.1 Diagnóstico laboratorial ............................................................................... 25

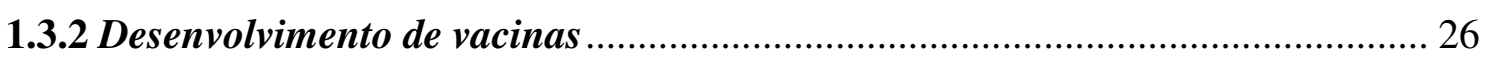

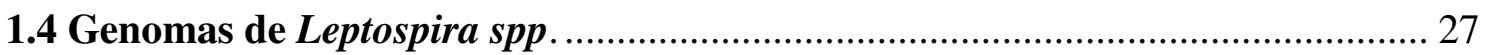

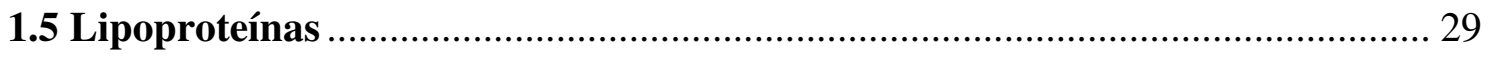

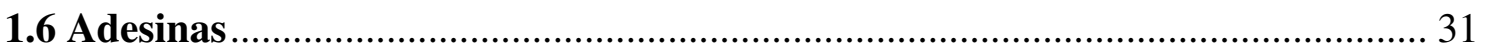

1.7 As proteínas LipL32 e HlyX de Leptospira …………………………………….... 32

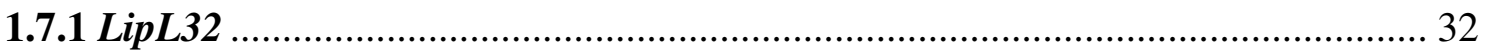

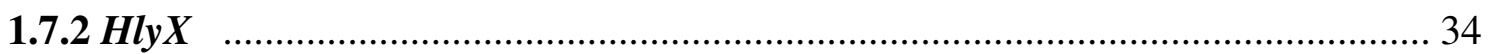

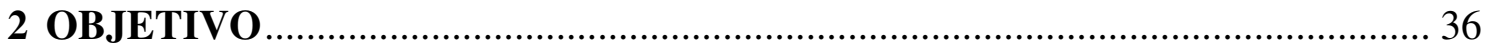

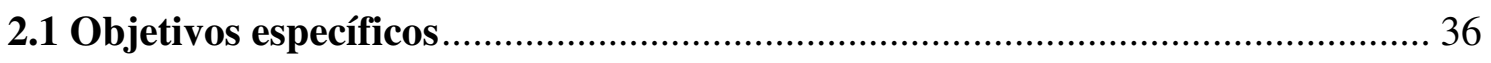

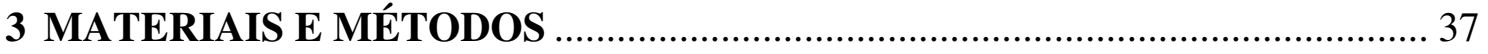

3.1 Lista de soluções e meios de cultura …………………………………………..... 37

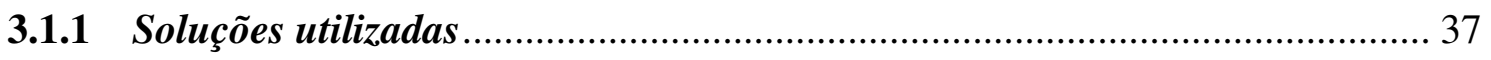

3.1.2 Meios de cultura utilizados ............................................................................ 38

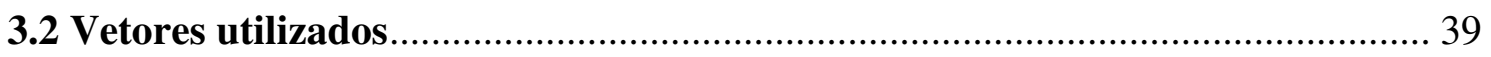

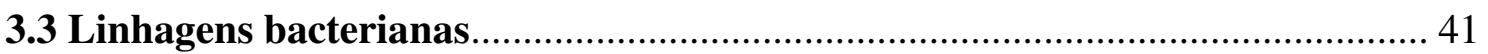

3.4 Soros de pacientes com leptospirose ………………………………………….... 41

3.5 Amplificação dos genes hlyX, lipL32 e dos fragmentos, N-terminal, intermediário e C-terminal de LipL32 ………………………………………….... 42

3.6 Subclonagem dos produtos da PCR ………………………………………....... 46

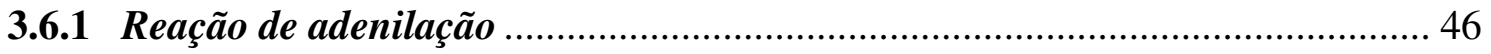

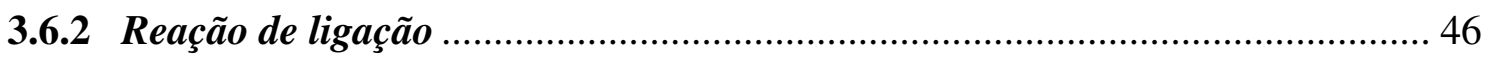

3.7 Transformação de bactérias competentes ............................................................. 47

3.8 Análise dos clones positivos através de extração com fenol-clorofórmio ……... 47 
3.8.1 Purificação dos plasmídeos

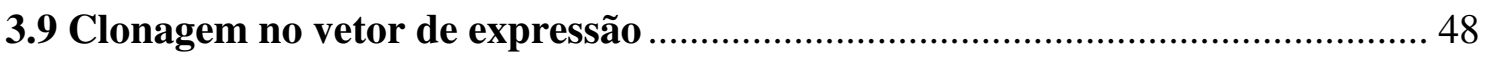

3.10 Expressão das proteínas recombinantes em $E$. coli

3.10.1 Expressão de LipL32 6xHis, LipL32 e do fragmento C-terminal de LipL32 em E. coli BL21 (SI).

3.10.2 Expressão de LipL32 com selênio-metionina (Se-M) em meio mínimo (M9 ON) 50

3.10.3 Expressão de HlyX e dos fragmentos $N$-terminal e intermediário de LipL32 em E.coli BL21(DE3) Star [plysS].... 50

3.11 Purificação das proteínas recombinantes. 51

3.11.1 Purificação da proteína HlyX após renaturação protéica 51

3.11.2 Purificação dos fragmentos de LipL32 e de LipL32 6xHis, através de cromatografia de afinidade a metais bivalentes ...................................................... 52

Purificação do fragmento N-terminal de LipL32 em condições desnaturantes...... 52

Purificação dos fragmentos intermediário e C-terminal da proteína LipL32 e LipL32 6xHis 52

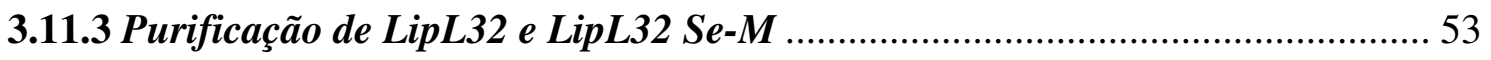

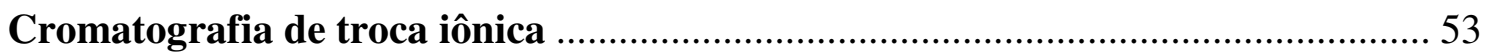

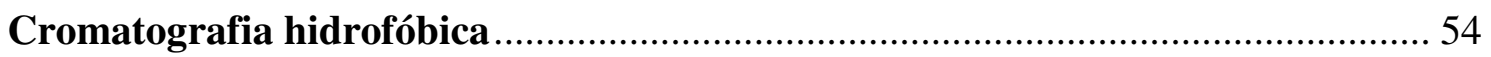

3.12 Eletroforese em gel de poliacrilamida com dodecil sulfato de sódio (SDS-

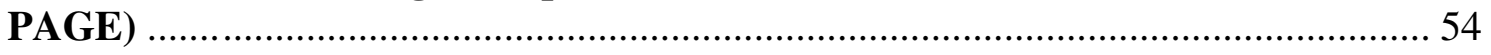

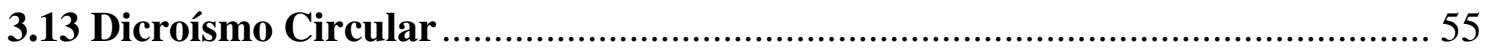

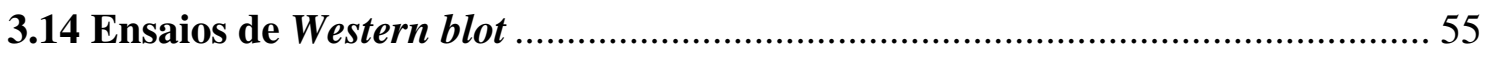

3.14.1 Produção de anticorpos gerados contra as proteínas purificadas .................... 55

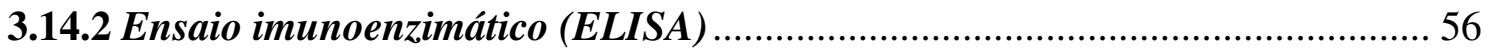

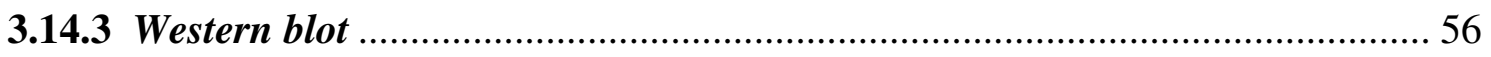

3.15 Ensaio de ligação das proteínas LipL32 6xHis e HlyX a componentes de

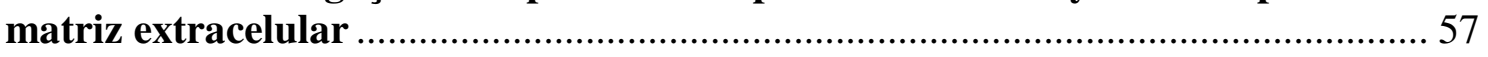

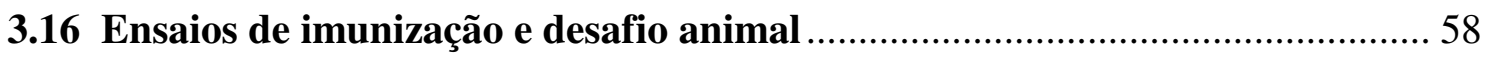

3.16.1 Ensaios de imunização ativa com as proteínas LipL32 e/ou HlyX e desafio

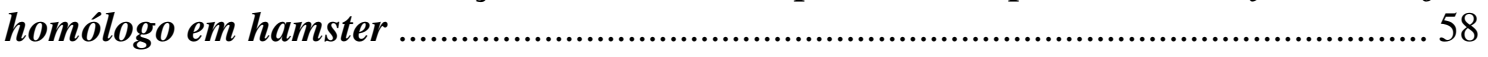

3.16.2 Determinação dos títulos de anticorpos IgG gerados contra LipL32 e HlyX... 59 
4.1 Amplificação dos genes $h l y X$, lipL32 e dos fragmentos correspondentes ao Nterminal, intermediário e C-terminal de LipL32

4.2 Expressão das proteínas recombinantes.

4.3. Purificação das proteínas recombinantes através de cromatografia de afinidade a metais bivalentes ou cromatografia de troca iônica e hidrofóbica....... 62

4.3.1 Purificação das proteínas expressas na forma solúvel, LipL32 6xHis e os fragmento intermediário e C-terminal de LipL32.

4.3.2 Purificação das proteínas expressas em corpúsculos de inclusão, HlyX e o fragmento $\mathrm{N}$-terminal de LipL32

4.3.3 Purificação de LipL32 e LipL32 Se-M através de cromatografia de troca iônica e hidrofóbica 66

4.4 Análises de Western blot

4.4.1 Análise da conservação da expressão de LipL32 e HlyX em Leptospira sp. e caracterização dos fragmentos derivados de LipL32

4.4.2 Detecção de anticorpos IgM e IgG dirigidos contra LipL32 e HlyX em soro de pacientes diagnosticados com leptospirose ............................................................ 70

Mapeamento do fragmento imunodominante de LipL32 ..................................... 71

4.5 Análise da estrutura secundária de HlyX, LipL32 6xHis e LipL32 ................... 74

4.6 As proteínas LipL32 e HlyX interagem com proteínas do hospedeiro .............. 76

4.6.1 As proteínas LipL32 e HlyX interagem com colágeno tipo IV e fibronectina

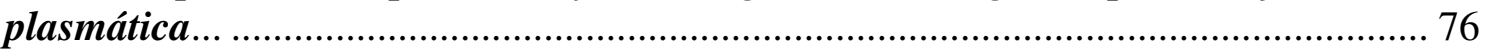

4.6.2 O fragmento C-terminal compete com LipL32 pela ligação ao colágeno tipo IV e à fibronectina plasmática

4.6.3 Competição de LipL32, do fragmento C-terminal de LipL32 e de HlyX com os

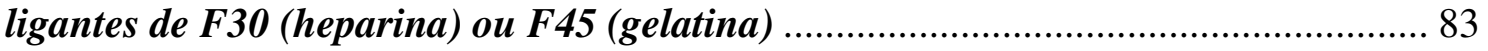

4.7 Ensaio de proteção contra desafio homólogo .................................................. 85

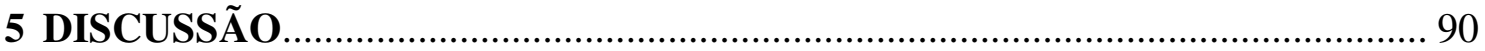

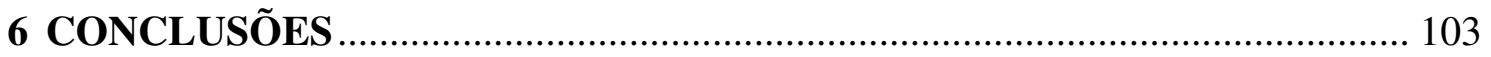

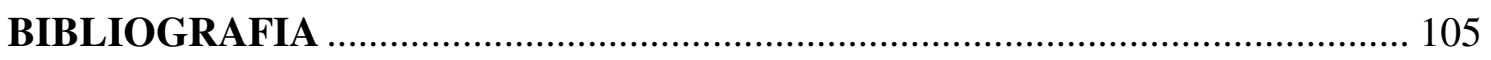

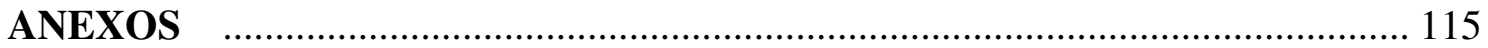




\section{INTRODUÇÃO}

\subsection{Espiroquetas}

As espiroquetas pertencem a um grupo de bactérias que possuem motilidade e morfologia típicas, distinguindo-se assim das demais bactérias. Possuem forma helicoidal e são flexíveis. Dentro do grupo das espiroquetas existem variações nas dimensões das células, que vão desde 0,09 a $0,75 \mu \mathrm{m}$ de diâmetro e 3 a $500 \mu \mathrm{m}$ de comprimento (Johnson, et al., 1977).

Estas bactérias pertencem à classe das Spirochaetes, ordem Spirochaetales, e estão divididas em três famílias. A primeira família, Spirochaetaceae, contém espécies do gênero Borrelia, Brevinema, Cristipira, Spirochaeta, Spironema e Treponema. A segunda família, Brachyspiraceae, contém o gênero Brachyspira (Serpetulina). A terceira família, Leptospiraceae, contém espécies dos gêneros Leptonema e Leptospira. Novas espécies de espiroquetas, que não puderam ser cultivadas in vitro até o momento, têm sido identificadas da cavidade oral humana, no intestino de cupins, e associadas a outros hospedeiros ou, ainda, de vida livre (Paster e Dewhirst, 2000). Na figura 1 está representado um esquema simplificado da taxonomia das espiroquetas.

Os habitats das espiroquetas são diversos, pois podem se estabelecer em ambientes como lama, águas de esgoto, trato digestivo de moluscos, e em túbulos renais de mamíferos (Charon, et al., 2002). Algumas espiroquetas podem causar doenças (Johnson, et al., 1977). Os gêneros Treponema, Leptospira e Borrelia contêm espécies patogênicas sendo o ser humano um dos possíveis hospedeiros (Paster e Dewhirst, 2000). Treponema pallidum é o agente causador da sífilis (Johnson, et al., 1977) e algumas espécies de Borrelia podem causar a doença de Lyme, transmitida pelo carrapato (Hengee, et al., 2003). Leptospiras podem causar a leptospirose, uma síndrome sistêmica consistindo de sintomas similares àqueles apresentados por outras doenças tropicais. Alguns casos também podem levar a meningite, danos hepáticos e falha renal representando a forma grave da doença (síndrome de Weil) (Palaniappan, et al., 2007). 


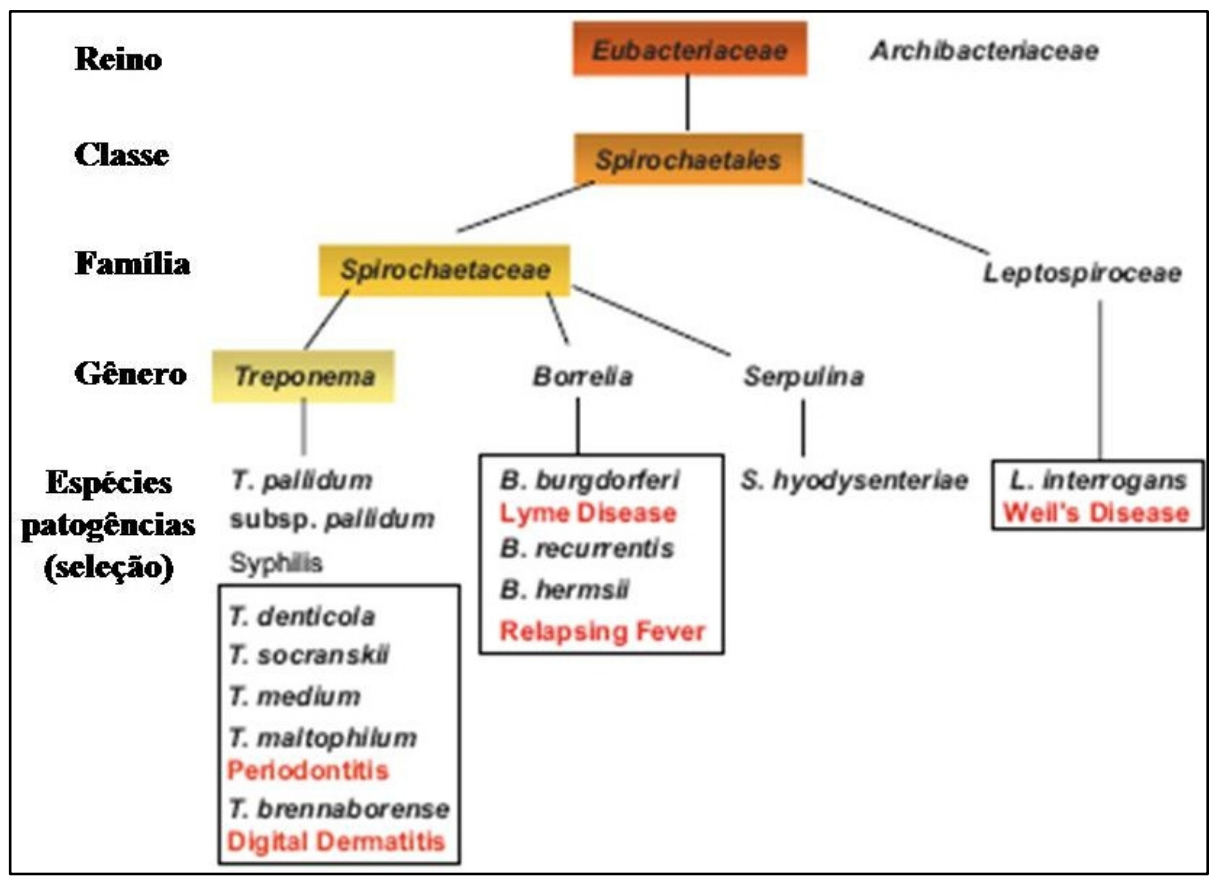

Figura 1 - Taxonomia das espiroquetas. A figura apresenta uma versão simplificada da taxonomia das espiroquetas focando nos gêneros importantes do ponto de vista clínico. Nos quadrados do organograma estão assinaladas em vermelho as doenças causadas pelas bactérias. Modificada de Schröder e colaboradores, 2008.

A organização e a composição da estrutura celular das espiroquetas são bastante semelhantes às das bactérias Gram-negativas, como por exemplo o padrão de organização das duas membranas. Por causa desta similaridade vários trabalhos postularam a presença de lipopolissacarídeos (LPS) em espiroquetas, que é um constituinte típico da parede das células das Gram-negativas, embora provas formais não existissem (Dahle, et al.,1996; Habicht, et al.,1986; Walker, et al.,1999). Entretanto, recentemente, através dos sequenciamentos dos genomas das espiroquetas, esta questão pôde ser esclarecida. Para Treponema e Borrelia, os genes de síntese de LPS estão ausentes, portanto a presença de LPS está excluída nestes gêneros (Frase, et al.,1997; Frase, et al., 1998; Norris e Weinstock, 2000; Seshadri, et al., 2004; Takayama, et al.,1987). Leptospira, em contraste, contém LPS com composição química única, quando comparado aos das demais Gram-negativas. Exibe na porção do lipídio A uma composição de ácidos graxos incomum e um único resíduo de fosfato metilado (Nahori, et al., 2005; Que-Gewirth, et al., 2004; Werts, et al., 2001). Estudos mostraram que os LPS de leptospiras ativam macrófagos através de CD14 e principalmente via receptores tipo Toll 2 (TLR-2) (Werts, et al., 2001). É importante ressaltar que embora Treponema e Borrelia não possuam LPS em sua composição celular, diferentemente da Leptospira, estas bactérias possuem outros glicolipídeos, como aqueles contendo diacilglicerol, encontrados em espécies de Treponema, e com funções similares ao ácido lipoteicóico (LTA) de bactérias 
Gram-positivas. Em Borrelia também são encontrados glicolípideos, porém de menor massa molecular (Shröder, et al., 2008). Na figura 2 podem ser visualizadas as diferenças entre a estrutura celular das bactérias Gram-negativas e das espiroquetas.

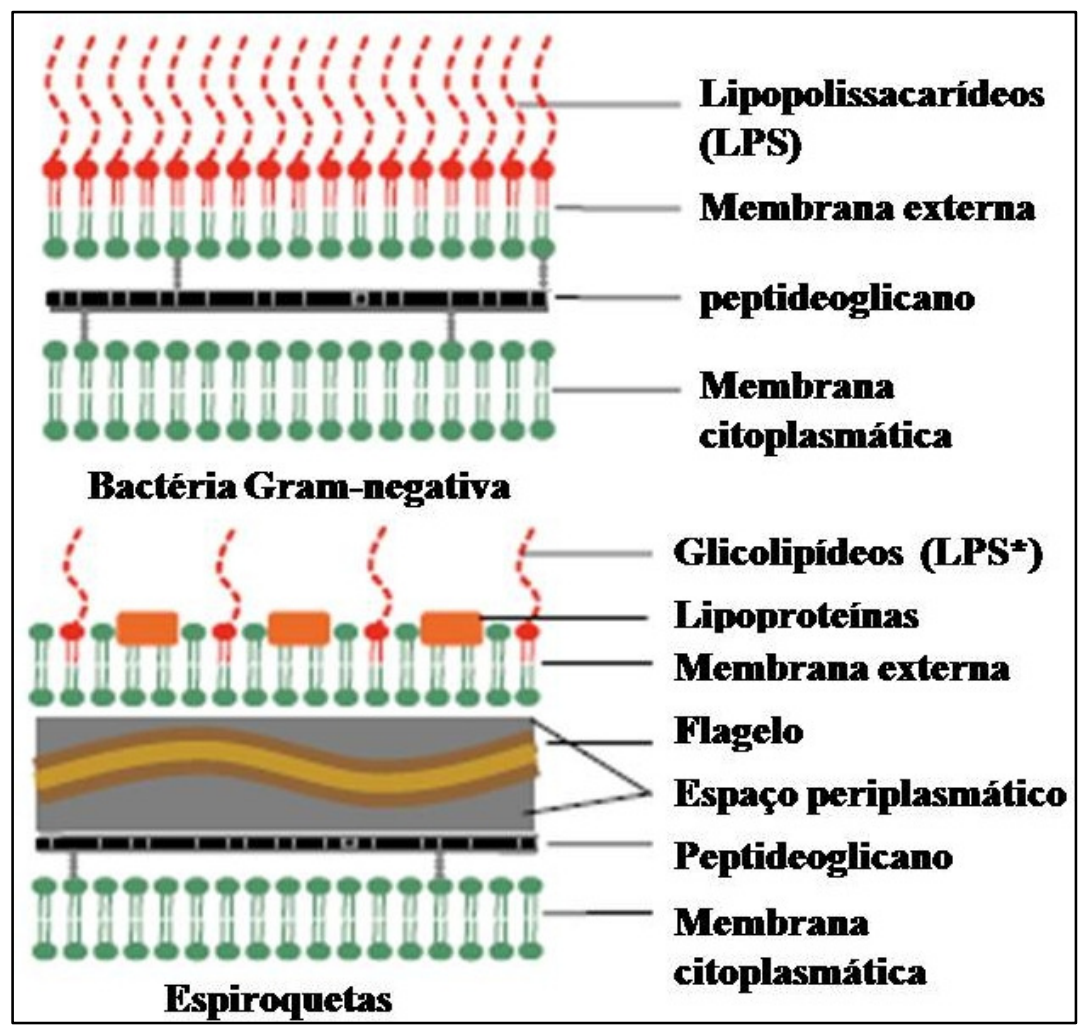

Figura 2 - Comparação entre a arquitetura das membranas de bactérias Gram-negativas e de espiroquetas. Bactérias Gram-negativas possuem duas membranas externas e uma pequena camada de peptideoglicano. A membrana externa é composta por LPS. As espiroquetas também exibem duas membranas, mas a membrana externa não está aderida à camada de peptideoglicano e o espaço periplasmático contem o flagelo. A membrana externa contém várias lipoproteínas e glicolipídeos. Os LPS* estão presentes em Leptospira e ausentes em Borrelia e Treponema. Modificada e extraída de Shröder e colaboradores, 2008.

Com relação à motilidade das espiroquetas, estas possuem flagelos periplasmáticos que são similares em muitos aspectos aos flagelos externos de bactérias com formato bastonete. Cada flagelo periplasmático está anexo subterminalmente em uma das pontas e se extende ao longo da célula em direção à outra ponta, conforme respresentado na figura 3. As espécies de espiroquetas possuem flagelos periplasmáticos que variam de acordo com o tamanho, número e com a sobreposição do flagelo periplasmático ao centro da célula (Charon, et al., 2002). 


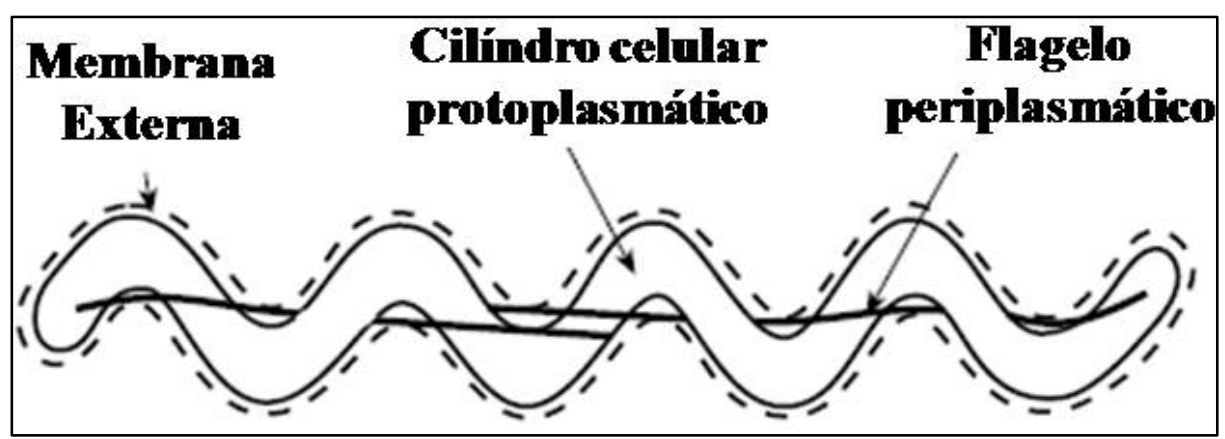

Figura 3 - Esquema ilustrando a membrana externa, cilindro celular protoplasmático e o flagelo periplasmático das espiroquetas. Adaptada de Charon e colaboradores, 2002.

\subsection{Gênero Leptospira}

Leptospiras são espiroquetas aeróbicas obrigatórias com membrana citoplasmática e parede celular de peptideoglicano, envolvida por uma membrana externa contendo porinas que permitem a troca de soluto entre o espaço periplasmático e o ambiente (Murphy, et al., 1980; Haake, 2000). As leptospiras normalmente possuem largura da ordem de $0,1 \mu \mathrm{m}$ e de 6 a $20 \mu \mathrm{m}$ de comprimento (Figura 4). Nos tecidos e dentro de fagócitos, estes organismos podem assumir uma aparência esférica ou granular. A forma delgada e helicoidal permite a sua passagem para dentro dos tecidos. Possuem dois flagelos periplasmáticos, cada um ligado subterminalmente em cada ponta, que se prolonga em direção ao centro da célula sem sobreposição (Goldestein, et al., 1994; Schmid, et al., 1989).

Leptospiras são incapazes de sintetizar ácidos graxos e na natureza somente se reproduzem dentro de seus hospedeiros, que incluem mamíferos, répteis e anfíbios (Murphy, et al., 1980). Preferem ambientes quentes, com $\mathrm{pH}$ neutros ou levemente alcalinos e podem sobreviver em água fresca ou solo úmido por meses (Kuriakose, et al., 1997; Simpson, et al., 1998). Recentemente foi demonstrado por Ristow e colaboradores (2008) que tanto as espécies de leptospiras saprofíticas como as patogênicas são capazes de formar biofilmes. A maioria produz biofilmes in vitro em superfícies abióticas, como vidro e poliestireno. A formação de biofilmes pela espécie saprófita L. biflexa também foi observada em condições com baixa disponibilidade de nutrientes, em tubos de vidro com água mineral natural. A formação de biofilmes é consistente com a vida saprofítica em água e pode contribuir para a sobrevivência das cepas patogênicas em diferentes ambientes e também na colonização do hospedeiro (Ristow, et al., 2008). 


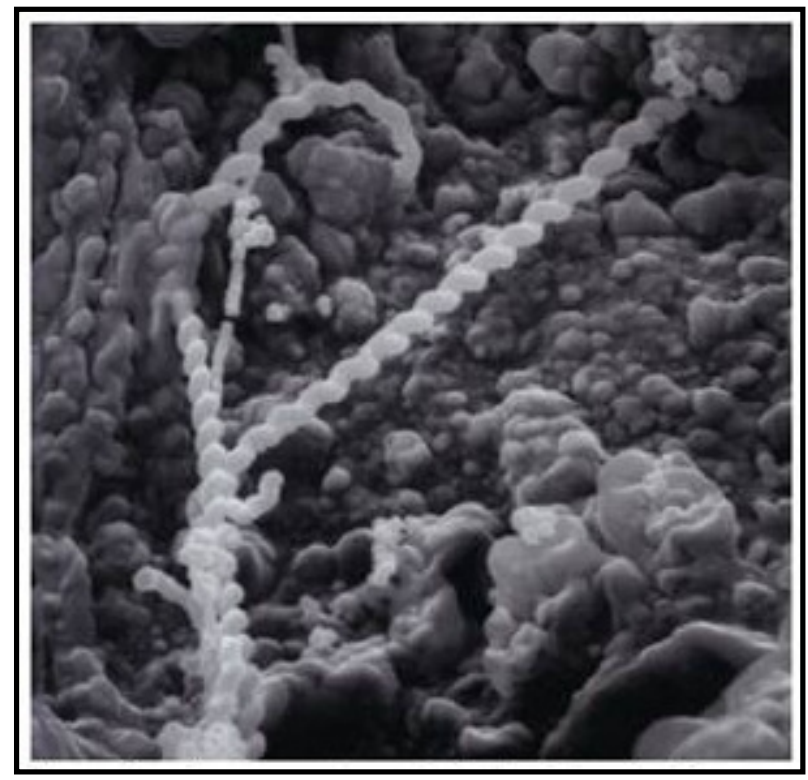

Figura 4 - Leptospiras aderidas ao epitélio da conjuntiva de equino, analisadas por microscopia eletrônica. Retirada de Bharti e colaboradores, 2003.

Tradicionalmente, as espécies de Leptospira têm sido divididas e classificadas dentro de mais de 250 sorovares de acordo com o teste de aglutinação microscópica (MAT). Utilizando-se o MAT, os sorovares são classificados dentro de sorogrupos determinados pelos antígenos que são compartilhados (sorogrupo-específicos) (Faine, et al., 1999), podendo muitas vezes ocorrer reações cruzadas entre diferentes sorovares.

Estudos genéticos, baseados em hibridação por homologia de DNA, têm permitido melhorar a precisão no delineamento das espécies dentro do gênero Leptospira (Yasuda, et al., 1987; Brenner, et al., 1999). Desta forma, os sorovares são encontrados em mais de uma espécie, como definido pela homologia genética, ilustrando a variabilidade na expressão do genoma desta bactéria. Atualmente existem 17 espécies genômicas (genomo-espécies): L. alexanderi, L.biflexa, L. borgpetersenii, L. fainei, L. inadai, L. interrogans, L. kirshneri, L. noguchii, L. santarosai, L. weilii, L. meyeri e L. wolbachii, e as genomoespécies 1, 2, 3, 4 e 5, ainda sem denominação (Bharti, et al., 2003). 


\subsection{Leptospirose}

A leptospirose é uma zoonose de importância global, causada pela infecção por espécies de leptospiras patogênicas (Vinetz, et al., 2001; Levett, 2001). As leptospiras infectam mamíferos, répteis e anfíbios, e estes animais servem como hospedeiros de manutenção para os mais de 250 sorovares do gênero Leptospira. Os ratos e outros roedores são a fonte de infecção mais importante para humanos. Um animal infectado pode permanecer assintomático e continuar expelindo leptospiras infectantes na urina por toda a sua vida (Murphy, et al., 1980). A infecção de animais de importância econômica, como por exemplo bovinos e suínos, representa um grande impacto na produção de leite e carne.

Os seres humanos são usualmente infectados através do contato com solo ou água contaminados com urina, tecidos de animais infectados ou mordidas de rato (Lecour, et al., 1989; Everard, et al., 1995). Desta forma, veterinários, agricultores, pessoas encarregadas da limpeza de esgotos e saneamento, e outros trabalhadores que mantêm contato com animais, solo, água e limpeza de áreas, estão freqüentemente expostos a uma possível infecção por leptospiras. Outro fator que tem desencadeado aumento no risco de infecção por leptospiras são habitações aglomeradas, aumentando assim a população de animais domésticos e roedores (Plank e Dean, 2000).

A apresentação clínica da leptospirose, em seres humanos, é bifásica, com uma fase aguda ou septicêmica que dura cerca de uma semana, seguida por uma fase imune, caracterizada pela produção de anticorpos e excreção de leptospiras na urina. Muitas das complicações da leptospirose estão associadas à localização das leptospiras dentro dos tecidos durante a fase imune, ou seja, durante a segunda semana da doença (Levett, 2001). Aproximadamente $90 \%$ dos casos identificados são moderados. Porém, sem o tratamento, que é baseado no uso de antibióticos orais como doxiciclina ou eritromicina, a fase septicêmica geralmente evolui para a fase imune, sendo neste caso o medicamento de escolha penicilina intravenosa (World Health Organization, 2003). Durante a septicemia (leptospiremia), as bactérias podem ser encontradas no sangue, no fluído da medula cerebral, no humor aquoso, e na maioria dos tecidos (Van Crevel, et al., 1994; MacClain, et al., 1984). A febre pode desaparecer de 1 a 3 dias antes do início da fase imune que pode durar de 4 a 30 dias. Durante a fase imune, as leptospiras desaparecem do sangue, mas podem ser recuperadas do humor aquoso, rins e urina. A leptospiúria pode persisitir por meses (Van Crevel, et al., 1994; MacClain, et al., 1984). 
Historicamente, a icterícia tem sido considerada o critério para a distinção entre as formas moderada e grave (síndrome de Weil), que é caracterizada por uma combinação da diminuição da atividade hepática e renal, hemorragia e colapso vascular (Murphy, et al., 1980). No fígado, as leptospiras podem induzir a apoptose dos hepatócitos, o que poderia limitar a resposta inflamatória, permitindo a proliferação dos microrganismos neste órgão (Merien, et al., 1998).

A maioria das mortes por leptospirose está diretamente relacionada ao comprometimento renal (Arean, et al., 1962), e neste caso, além dos antibióticos se faz necessária uma terapia de suporte, que consiste principalmente na diálise, importante na insuficiência renal, desequilíbrio hidroeletrolítico e hemorragia (WHO, 2003). Pacientes com falha renal aguda possuem alta excreção de sódio e potássio, que aumentam e caem concomitantemente (Seguro, et al., 1990). A patogênese renal pode envolver uma endotoxina de Leptospira conhecida como glicolipoproteína (GLP), que inibe a ATPase sódio/fosfato (Burth, et al., 1997).

Nos últimos anos, a hemorragia pulmonar também tem se apresentado como uma importante forma de manifestação clínica da leptospirose. Afetando cerca de $70 \%$ dos pacientes esta vem sendo considerada em alguns países como uma da principais causas de morte (Bharti, et al., 2003; Levett, 2001; Seijo, et al., 2002).

No Brasil, a média do número de casos de leptospirose relatados em humanos, referente aos anos de 1997 a 2008, é de aproximadamente 3.233 por ano (segundo dados divulgados pelo Ministério da Saúde em 20/01/2009). Porém, estes números números não refletem em nada a realidade desta doença no país. As diversas apresentações clínicas da leptospirose juntamente com o baixo índice de suspeita frequentemente resultam em um diagnóstico errado (Ko, et al.,1999). Em regiões tropicais, a leptospirose é mais comumente confundida com a dengue. Estas duas infecções são virtualmente indinstingíveis nos estágios iniciais (febre, dor de cabeça e mialgias estão presentes em ambas) e além disso possuem igual distribuição temporal devido às condições climáticas. Em 1996, a área urbana de Salvador, no Brasil, teve epidemias de dengue e leptospirose concomitantes e cerca de $42 \%$ dos pacientes foram inicialmente diagnosticados, erroneamente, com dengue (Ko, et al., 1999). 


\subsubsection{Diagnóstico laboratorial}

Ainda não existe nenhum teste diagnóstico para a leptospirose que seja sensível, específico, de baixo custo, rápido e amplamente disponível.

O teste de referência recomendado pela Organização Mundial de Saúde (OMS) para o diagnóstico sorológico de leptospirose é o teste de aglutinação microscópica (MAT) (WHO, 2003), onde o soro do paciente reage com uma suspensão viva ou inativada de Leptospira. Após a incubação, a mistura soro-antígeno é examinada ao microscópio de campo escuro para a observação da aglutinação e para a determinação dos títulos de diluição. Porém, a interpretação deste teste é complicada pela alta proporção de reações cruzadas que ocorrem entre diferentes sorogrupos, especialmente em amostras colhidas na fase aguda da doença (Levett, 2001). Assim, este ensaio acaba tornando-se complexo, de difícil controle, padronização, leitura, interpretação, e a sua utilização na identificação de sorovares ainda é controversa (Levett, et al., 2003).

Outro grande problema com este ensaio é a dificuldade para manter culturas de sorovares, pois existe a chance de contaminação entre os mesmos, sendo preciso um controle periódico, além de representar sério risco de contaminação local (WHO, 2003; Bajani, et al., 2003). Pela complexidade do teste de microscopia de aglutinação, têm sido desenvolvidos testes rápidos para a observação de anticorpos na fase aguda da infecção como o uso de testes de ELISA para IgM. Técnicas aplicadas para a detecção de anticorpos contra leptospiras incluem: imunofluorescência, imunoensaio e imunoeletroforese (Levett, 2001). Métodos moleculares estão sendo desenvolvidos, principalmente baseados em desenho de primers, uso de PCR e análise de restrição. Vários pares de primers para a detecção por PCR de Leptospira têm sido descritos, freqüentemente baseados nos genes 16S ou 23S rRNA e em elementos repetitivos (Heinemann, et al., 2000; Levett, 2001). No entanto, estes testes diagnósticos ainda estão sendo padronizados e não são aceitos como métodos de referência (Bajani, et al., 2003; Levett, 2001), pois apesar de serem altamente sensíveis e específicos, eles não têm sido sistematicamente comparados entre si e com o teste padrão (MAT) (Bajani, et al., 2003). 


\subsubsection{Desenvolvimento de vacinas}

Os estudos realizados até o momento indicam que a imunidade para Leptospira parece ser humoral e sorovar específica (Faine, et al., 1999). Desta maneira, a imunização utilizando-se leptospiras inativadas ou atenuadas protege somente contra o sorovar homólogo ou antigenicamente similar. As vacinas devem consequentemente conter sorovares representativos daqueles presentes na população a ser imunizada (Faine, et al., 1999). Este tipo de imunização tem sido usada há muitos anos com a finalidade de induzir imunidade em animais e humanos. As primeiras vacinas eram compostas de suspensões de leptospiras mortas cultivadas em meio contendo soro, e efeitos colaterais eram comuns. Vacinas modernas preparadas usando meio livre de proteína geralmente não possuem efeitos adversos (Faine, et al., 1999). Existem estudos sobre o desenvolvimento de vacinas contra a leptospirose humana em países como Cuba, Rússia, China e França (Martínez-Sánchez, et al., 1998; Ikoev, et al., 1999; Yan, et al., 2003; Rodriguez-Gonzales, et al., 2004), com preparações semelhantes às bacterinas veterinárias. Vacinações realizadas na China, Vietnam e Japão com sorovares específicos endêmicos destas localidades após episódios de enchentes, aparentemente obtiveram sucesso (Faine, et al., 1982; Faine, et al., 1999).

Embora útil para animais, esta abordagem não é recomendável para seres humanos, constantemente expostos a numerosos sorovares através das diversas ocupações e viagens. Além do mais, a variação não acontece somente nas diferentes regiões, mas também ao longo do tempo (Lecour, et al., 1989; Trevejo, et al., 1998; Van Crevel, et al., 1994; Park, et al., 1989; Caldas, et al., 1978; Sehgal, et al., 1995), fazendo-se desejável uma vacina de amplo espectro (Plank e Dean, 2000). Ainda, a imunidade gerada pelas vacinas celulares não induz memória, havendo a necessidade de vacinações anuais ou bianuais e reações locais são comuns após as vacinações (Haake, et al.,1999). Atualmente tem sido priorizado o desenvolvimento de vacinas com componentes bem definidos, com o objetivo de alcançar máxima proteção por tempo prolongado e com mínimos efeitos adversos (McBride, et al., 2005).

Foram encontrados anticorpos em soros de pacientes com leptospirose que se ligam a diferentes proteínas de membrana externa e do espaço periplasmático, bem como a lipopolissacarídeos (LPS). A variação entre os LPS dos sorovares de Leptospira, representa um desafio para o desenvolvimento de uma vacina uniforme aplicável em seres humanos (Haake, et al., 1999). Portanto, acredita-se que os esforços para a obtenção de uma vacina eficaz devam se concentrar em proteínas de membrana externa que sejam conservadas nos 
sorovares patogênicos e que sejam imunodominantes. Pesquisas voltadas para este propósito estão sendo realizadas (Haake, et al., 1999). Os genomas de 4 sorovares patogênicos e de 1 sorovar saprofítico, foram sequenciados (Ren , et al., 2003; Nascimento, et al., 2003; Bulach, et al., 2006; Picardeau, et al., 2008). As informações provenientes destes genomas representam uma importante contribuição para o estudo da biologia do microrganismo e abre perspectivas para estudos de genoma funcional. A vacinologia reversa (Rappuoli e Covacci, 2003) tem sido útil para a descoberta de potenciais candidatos vacinais contra a meningite e pneumonia, através da informação genômica de Neisseria meningitides (Pizza, et al., 2000) e Streptococcus pneumoniae (Wizemann, et al., 2001). As informações genômicas obtidas com o sequenciamento dos genomas de Leptospira (Gamberini, et al., 2005) também vêm auxiliando na busca de candidatos a vacina e ao diagnóstico da leptospirose.

\subsection{Genomas de Leptospira spp.}

A recente utilização de técnicas moleculares utilizadas no refinamento da taxonomia do gênero Leptospira tem revelado extensas diversidades genéticas dentro deste gênero, que possui mais de 12 espécies patogênicas e saprofíticas reconhecidas (Brenner, et al., 1999; Levet, 2001). A análise dos genomas de Leptospira revelou diferenças entre as espécies patogênicas e saprofíticas, sugerindo prováveis funções biológicas de diversas proteínas, além de adicionar informações sobre a relação deste microrganismo com o ambiente.

Até então, foi realizado o sequenciamento do genoma de 5 sorovares pertencentes a 3 espécies de Leptospira, sendo 2 espécies patogênicas e 1 espécie saprofítica, L. interrogans sorogrupo Icterohaemorrhagiae sorovar Lai (Ren, et al., 2003), L. interrogans sorovar Copenhageni (Nascimento, et al., 2003), L. borgpetersenii sorovar Hardjo (Bulach, et al., 2006) e L. biflexa sorovar Patoc (Picardeau, et al., 2008).

O genoma da L. interrogans sorogrupo Icterohaemorrhagiae sorovar Lai consiste de dois cromossomos, sendo o maior de 4,33 Mpb e o menor de $359 \mathrm{Kpb}$, com um total de 4.768 genes preditos (Ren, et al., 2003). O sequenciamento do genoma da L. interrogans sorovar Copenhageni mostrou que esta cepa também possui dois cromossomos circulares: o cromossomo maior posssui 4,27 $\mathrm{Mpb}$ e o cromossomo menor possui $350 \mathrm{Kpb}$, aproximadamente (Nascimento, et al., 2004). A comparação realizada entre os dois sorovares de L. interrogans revelou que, apesar das similaridades genéticas gerais, existem significantes diferenças estruturais, incluindo uma inversão no cromossomo maior e grandes variações no número e distribuição de elementos de sequências de inserção (Nascimento, et al., 2004). 
Foram identificadas diferenças entre o sorovar Lai e Copenhageni em genes envolvidos na biossíntese da cadeia $\mathrm{O}$ de lipopolissacarídeos, oferecendo um importante começo para a elucidação da complexidade dos antígenos polissacarídicos presentes na superfície deste microorganismo. Estas diferenças podem estar associadas à adaptação destes sorovares em diferentes hospedeiros (Nascimento, et al., 2004).

O genoma de L. borgpetersenii sorovar Hardjo é aproximadamente $700 \mathrm{Kpb}$ menor quando comparado ao genoma de L. interrogans e possui uma menor densidade codificante resultante da presença de sequências de inserção, refletindo-se em uma redução do genoma (Bulach, et al., 2006). A perda de função de gene não é aleatória, mas é centrada na diminuição da sinalização ambiental e no transporte e utilização de metabólitos. Estas características distinguem L. borgpetersenii de L. interrogans, sendo esta útima uma espécie que possui um menor decaimento genético e que sobrevive a extensivas passagens por ambientes aquáticos e no hospedeiro mamífero, diferentemente da primeira que parece estar se tornando dependente do hospedeiro (Bulach, et al., 2006). O genoma de L.biflexa, que é a espécie saprofítica de vida livre presente em ambientes aquáticos, possui 3.590 genes codificadores de proteínas distribuídos através de três "replicons" circulares: o cromossomo maior possui 3,6 Mpb, o segundo replicon tem $278 \mathrm{kpb}$ e também carrega genes essenciais e o terceiro replicon possui $74 \mathrm{Kpb}$ (Picardeau, et al., 2008).

As análises comparativas realizadas entre as sequências dos genomas apontaram evidências de que L. biflexa é um excelente modelo para o estudo de evolução de Leptospira, devido aos 2052 genes (61\%) representarem um genoma ancestral que existiu antes da divergência das espécies patogênicas e saprofíticas. As comparações realizadas entre o genoma da L. biflexa e o genoma das duas espécies de Leptospira patogênica sequenciadas revelaram que aproximadamente um terço dos genes da L. biflexa estão ausentes em Leptospira patogênica (Picardeau, et al., 2008). Em constraste, os genomas das espécies de Leptospira patogênica analisadas sofreram frequentes rearranjos, muitas vezes envolvendo recombinação entre sequências de inserção. A identificação de genes comuns para as duas espécies patogênicas, L. interrogans e L. borgpetersenii, mas ausente em L. biflexa, é indicativa do papel destes genes na patogênese. Diferenças nas capacidades de percepção ambiental de L. biflexa, L. borgpetersenii e L. interrogans sugerem um modelo que postula que a perda das funções da transdução de sinal em L. borgpetersenii tem diminuído a sua sobrevivência fora do hospedeiro mamífero, enquanto L. interrogans tem conservado funções sensoriais ambientais que facilitam a transmissão da doença através da água (Picardeau, et al., 2008). 


\subsection{Lipoproteínas}

Lipoproteínas de superfície estão envolvidas na interação entre patógeno e hospedeiro. Sinais ambientais podem regular a expressão das lipoproteínas e estas ainda podem ser reguladas no hospedeiro, sofrendo variação antigênica como uma estratégia para evadir ao sistema imune. Lipoproteínas também estão envolvidas na patogênese da doença através de sua habilidade em desencadear uma resposta inflamatória no hospedeiro (Haake, 2000).

O sequenciamento dos genomas das espiroquetas Treponema pallidum e Borrelia burgdorferi revelaram ortológos de genes codificantes de todos os componentes essenciais da maquinaria secretória (Fraser, et al., 1997; Fraser, et al., 1998). Segundo a revisão de Duong (1997), que compara os genes da maquinaria das espiroquetas e de Escherichia coli, as lipoproteínas emergentes do ribossomo ligam-se através do peptídeo sinal às partículas contendo Ffh, dirigindo-os ao complexo de pré-proteína translocase presente na membrana citoplasmática.

Como observado na figura 5, as prolipoproteínas são secretadas ao longo da membrana citoplasmática através do complexo de proteínas translocase, que consiste de um canal transmembrana SecYE contendo SecA no lado citoplasmático e SecDF no lado periplasmático da membrana citoplasmática. A secreção através do complexo translocase envolve um ciclo dependente de energia, no qual a SecA liga-se ao peptídeo sinal, impulsionando-o através do canal transmembrana (Wu, 1996).

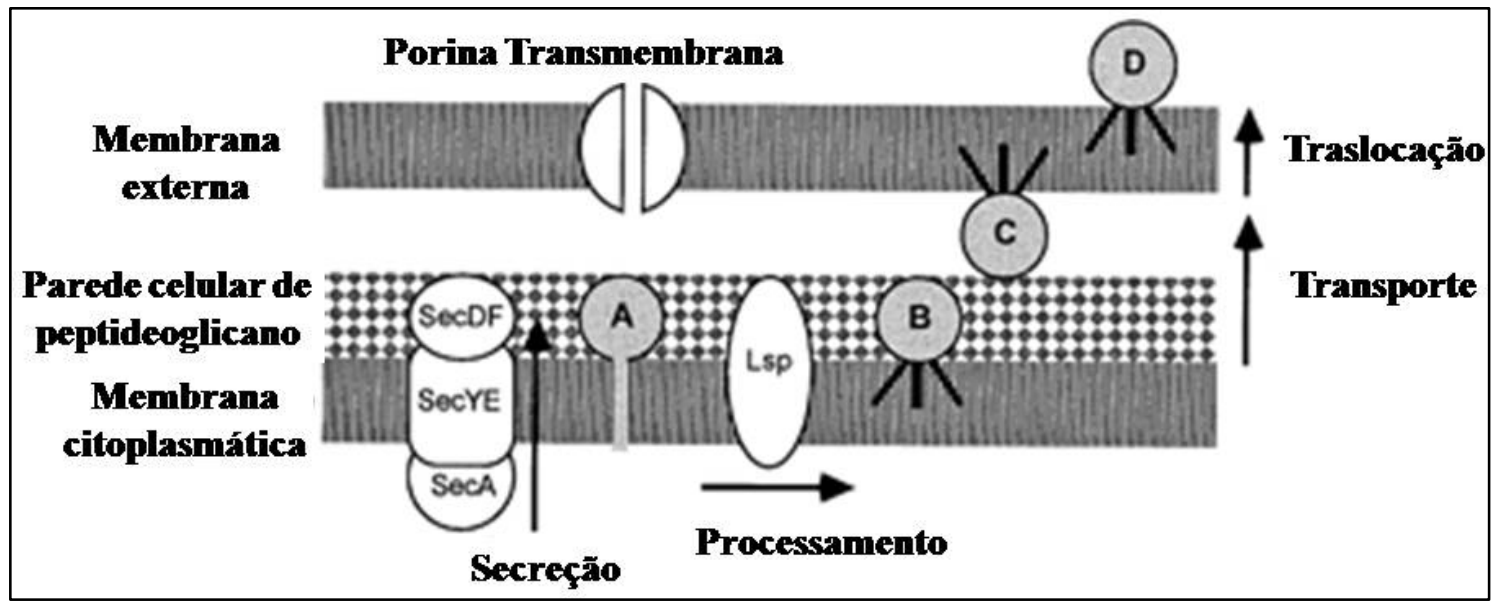

Figura 5 - Modelo da exportação de lipoproteínas em espiroqueta. O modelo acima basea-se no que está estabelecido sobre exportação de lipoproteínas de bactéria e os ortólogos de proteínas secretórias em genomas de espiroquetas. O mecanismo pelo qual as lipoproteínas de espiroquetas são expostas não foi demonstrado experimentalmente. A, prolipoproteína (com peptídeo sinal) imediatamente após a secreção; B, sub-superfície da lipoproteína no folheto externo da membrana citoplasmática; C, sub-superfície da lipoproteína no folheto interno da membrana externa; D, lipoproteína exposta na superfície no folheto externo da membrana externa; Lsp, prolipoproteína peptidase sinal. Adaptada de Haake, 2000. 
Depois disso, a SecA volta a ligar-se à próxima parte da proteína que está sendo secretada. Este ciclo continua até a proteína inteira ter sido completamente transportada através da membrana citoplasmática. É muito provável que lipoproteínas, bem como todas as outras proteínas com peptídeo sinal, sejam secretadas desta maneira (Wu, 1996). Após a secreção através da membrana citoplasmática, as proteínas são lipidadas e clivadas no resíduo de cisteína no sítio sinal de processamento de lipoproteína.

O processamento de lipoproteína é uma via de biossíntese de três passos que ocorre no lado periplasmático da membrana citoplasmática e envolve três enzimas separadas localizadas na membrana (Wu, 1996). Homólogos para todas as três enzimas requeridas para a biossíntese em E. coli têm sido encontrados tanto em Treponema pallidum como em Borrelia burgdorferi. Os detalhes do processamento foram originalmente testados em E. coli para a lipoproteína mureína e são presumivelmente similares em outras bactérias Gram-negativas e também em espiroquetas. A primeira das três enzimas na via de processamento de lipoproteína é a fosfotidilglicerol prolipoproteína diacilglicerol transferase (Lgt). Esta enzima transfere um grupo diacilglicerol (contendo dois ácidos graxos) do fosfotidilglicerol para o átomo de enxofre da cisteína. A segunda enzima na via é a prolipoproteína peptidase sinal (Lsp), que remove proteolíticamente o peptídeo sinal, fazendo da cisteína o novo aminoácido N-terminal. A terceira enzima é um fosfolipídeo: apolipoproteína transacilase (Lnt) que transfere um terceiro ácido graxo proveniente de um fosfolipídeo de membrana para o átomo de nitrogênio da cisteína. Após o processamento, as lipoproteínas terão três ácidos graxos ligados ao resíduo de cisteína (Haake, 2000).

Os estudos do sequenciamento dos genomas de espiroquetas têm revelado um grande número de genes codificantes para possíveis lipoproteínas (Frase, et al., 1997; Fraser, et al., 1998). A presença de um resíduo de Cys após um peptídeo sinal é uma evidência sugestiva de que uma proteína é lipidada. Em espiroquetas, a variabilidade de aminoácidos no sítio de clivagem da peptidase da lipoproteína sinal, incluindo a posição -3 em relação a cisteína, faz com que o reconhecimento dos sítios de clivagem da peptidase da lipoproteína sinal seja menos preciso do que nas demais bactérias (Haake, 2000). Para definir o lipobox das espiroquetas, Haake (2000) reuniu dados presentes na literatura para identificar lipoproteínas de espiroquetas, para as quais evidências experimentais de modificação de lipídios estavam disponíveis. Vinte e seis sequências foram obtidas das lipoproteínas produzidas pelas espécies de Leptospira, Treponema, Borrelia e Brachyspira. 
A sequência encontrada para o lipobox de espiroquetas foi: -Leu(Ala,Ser)-4Leu(Val,Phe,Ile)-Ile(Val,Gly) $)_{-2}$-Ala(Ser,Gly) ${ }_{-1}$-Cys $_{+1}$ (Haake, 2000). São exemplos de lipoproteínas de Leptospira (Setubal, et al., 2006), LipL32 (Haake, et al., 2000), LipL41 (Haake, et al.,1999), LipL21 (Cullen, et al.,2003), OmpL1 (Haake, et al.,1999), Loa22 (Ristow, et al.,2007), e Lsa24 (Barbosa, et al.,2006).

\subsection{Adesinas}

A capacidade das espiroquetas de aderir à superfície de células eucarióticas e a proteínas de matriz extracelular é essencial para a patogênese da leptospirose (Haake, 2000). O início da infecção requer a aderência das bactérias a células não fagocíticas ou a componentes de matriz extracelular, e muitos microorganismos entram nas células do hospedeiro após a ligação a estruturas específicas de superfície. As bactérias expressam moléculas de adesão associadas à superfície, geralmente chamadas de adesinas, que reconhecem receptores e células eucarióticas, proteínas ou carboidratos dos componentes de matriz extracelular (Preissner e Chhatwal, 2005). A matriz do tecido conjuntivo e as superfícies das células do hospedeiro servem como suporte para a infiltração de bactérias patogênicas durante a invasão e colonização, particularmente sob condições de injúria ou trauma. Moléculas de adesão encontradas na matriz extracelular ou na lâmina basal, como colágeno, fibronectina, laminina e outras proteínas de matriz, assim como proteínas do plasma (Haake, 2000) ou receptores de adesão e integrinas presentes nas células do hospedeiro, podem interagir diretamente com a bactéria através de suas adesinas de superfície e facilitar a entrada de patógenos para dentro dos tecidos (Preissner e Chhatwal, 2005). Em Leptospira foram encontradas adesinas que interagem com componentes de matriz extracelular, sendo elas Lsa24 (LenA ou LfhA) (Barbosa, et al., 2006), Lig (A e B) (Choy, et al., 2007), a família de proteínas parálogas Len (B, C, D, E e F) (Stevenson, et al., 2007) e LipL32 (Hoke, et al., 2008; Hauk, et al., 2008). A proteína Lsa24 foi descrita como sendo uma adesina capaz de se ligar a laminina, preferencialmente aos resíduos de açúcar desta molécula (Barbosa, et al., 2006). As proteínas LigA e LigB são proteínas expressas na superfície, em condições de alta osmolaridade, e possuem domínios imperfeitos de imunoglobulina. Estas proteínas mostraram ser capazes de aderir tanto a colágeno tipo IV como a fibronectina plasmática (Choy, et al., 2007). As proteínas Len (A, B, C, D, E e F) pertencem a uma família de proteínas de membrana externa, similares a endostatinas, que se ligam a laminina. As proteínas LenA e LenB também ligam-se ao fator $\mathrm{H}$, um importante regulador da via alternativa do sistema 
sistema complemento. As Len (B, C, D e F) exibiram afinidade por fibronectina. (Stevenson, et al., 2007).

\subsection{As proteínas LipL32 e HlyX de Leptospira}

\subsubsection{LipL32}

Muitas das proteínas da membrana externa das espiroquetas são lipoproteínas. A membrana externa de leptospira possui um perfil relativamente complexo de proteínas, sendo a mais abundante, a lipoproteína de superfície LipL32 (Cullen, et al., 2005; Haake, et al., 2000). Em uma comparação utilizando-se as seqüências de aminoácidos da LipL32 de seis espécies de Leptospira, encontrou-se $97,8 \%$ de similaridade e nenhuma outra seqüência com homologia significativa a LipL32 foi identificada no banco de dados do Genbank, definindo a alta especificidade para estas bactérias (Haake, et al., 2000). Porém, recentemente foi encontrada uma proteína ortóloga de LipL32 no genoma de Pseudoalteromonas tunicata. Esta proteína apresenta similaridades funcionais e reatividade cruzada com LipL32 (Hoke, et al., 2008).

A sequência de aminoácidos de LipL32 é compatível com as regras que caracterizam as lipoproteínas procarióticas (Hayashi e Wu, 1990; Pusgley, et al., 1993). O peptídeo sinal de LipL32 possui uma região amino-terminal básica (incluindo lisinas nas posições 2 e 3), uma região hidrofóbica (posição de aminoácidos 4 a 19) seguido por um sítio de clivagem de peptidase sinal, I-T-A-C (Haake, et al., 2000) (Figura 6).

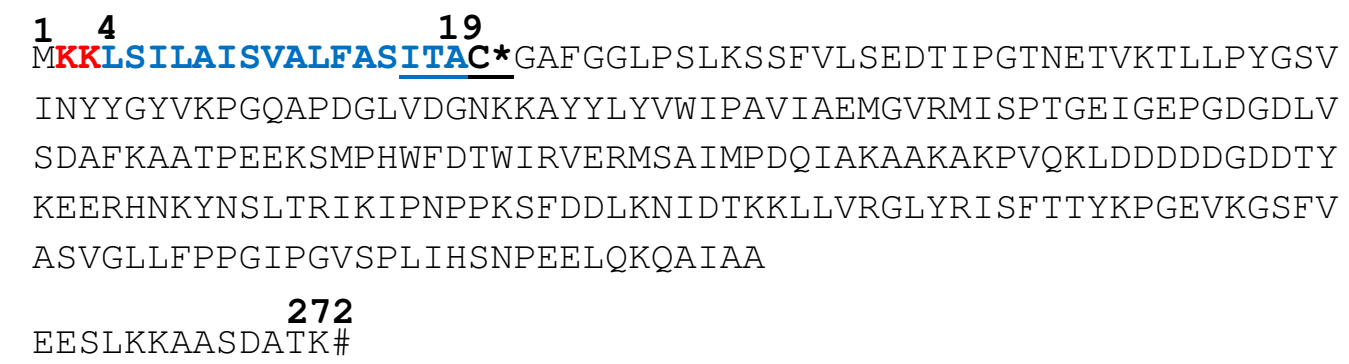

Figura 6 - Sequência de aminoácidos da LipL32. A posição de aminoácidos 1 a 20 representa a sequência sinal. Em vermelho estão indicados os aminoácidos básicos da sequência sinal, duas lisinas nas posições 2 e 3. Em azul está representada a região hidrofóbica, posições 4 a 19 aa. A sequência sublinhada refere-se ao sítio de reconhecimento para clivagem pela peptidase sinal. C* na posição 20 aa representa a cisteína lipidada (Haake, et al. ,2000). 
A proteína LipL32 é altamente expressa nas espécies patogênicas de Leptospira, tanto in vitro como in vivo, mas a sua expressão não foi detectada nas espécies saprofíticas (Haake, et al., 2000; Guerreiro, et al., 2001). Recentemente, o sequenciamento do genoma de $L$. biflexa mostrou a ausência do gene que codifica LipL32 nesta espécie saprofítica (Picardeau, et al., 2008).

Estudos envolvendo células de túbulo proximal renal de camundongos mostraram que LipL32 induziu um aumento significativo na expressão de TLR2 (Toll Like Receptor type 2) nestas células e que estes receptores são requeridos para a resposta inflamatória precoce (Werts, et al., 2001; Yang, et al., 2006). Outros estudos realizados com estas mesmas células mostraram que quando tratadas com LipL32, elas apresentaram uma resposta inflamatória, verificada através da produção de transcritos de MCP-1 (proteína-1 quimioatraente de monócitos), RANTES (expresso e secretado por célula $\mathrm{T}$ normal, regulada por ativação), iNOS (óxido nítrico sintetase), TNF- $\alpha$ (fator de necrose tumoral $\alpha$ ), aumento na ligação nuclear de NF-кB (fator-кB nuclear) e do fator de transcrição AP-1 (proteína ativadora -1) (Yang, et al., 2002). Portanto, sugere-se que a proteína LipL32 seja o componente de membrana externa mais abundante que deflagra in vivo o quadro clínico de nefrite túbulointersticial (efeito citotóxico) após a infecção por Leptospira (Yang, et al., 2002).O papel da LipL32 na patogênese da leptospirose requer investigação detalhada, pois LipL32 também demonstrou induzir TNF- $\alpha$ em células monocíticas humanas (Yang, et al., 2002). Immunoblottings realizados para a pesquisa de anticorpos gerados contra proteínas de leptospiras em soros de pacientes com leptospirose indicaram a presença de anticorpos IgG contra LipL32 durante a infecção. Nestes ensaios, extratos totais de isolados clínicos de $L$. interrogans foram utilizados e anticorpos IgM produzidos contra LipL32 não foram encontrados (Guerreiro, et al., 2001).

Recentemente, estudos usando lipL32 mutante de Leptospira interrogans (obtida por mutagênese realizada através de transposon) mostraram que a proteína codificada por este gene, embora presente somente em leptospiras patogênicas, parece não participar da infecção em modelo animal, seja na fase aguda ou na fase crônica da doença (Murray, et al., 2008). Curiosamente, estudos realizados com outra proteína de membrana externa de Leptospira (Loa22), presente tanto em cepas patogênicas como naquelas de vida livre (Picardeau, et al., 2008), mostraram que esta proteína é imprescindível para a virulência da bactéria (Ristow, et al., 2007). 
O alto grau de conservação de LipL32 entre as diferentes espécies de Leptospira patogênicas indica que a estratégia de sorodiagnóstico baseado neste antígeno pode ser efetiva em qualquer caso de infecção, independente do sorovar, e específica para o diagnóstico da leptospirose (Guerreiro, et al., 2001). Ensaios baseados em ELISA, utilizando LipL32 recombinante, mostraram que este antígeno, sendo imunodominante, pode ser útil para o diagnóstico de leptospirose humana (Flannery, et al., 2001; Haake, et al., 2000). O uso da proteína recombinante para a detecção diagnóstica da doença canina através de ELISA mostrou uma atividade específica de anticorpos presentes nos soros dos cães infectados contra este antígeno. Este ensaio demonstrou ser sensível, específico e exato, quando comparado ao método diagnóstico padrão, o teste de aglutinação microscópica (MAT) (Dey, et al., 2004).

Componentes de proteínas da membrana externa de Leptospira representam potenciais candidatos vacinais (Haake, et al., 2000) e, sendo LipL32 a proteína de superfície mais abundante e ainda presente somente em leptospiras patogênicas, foi considerada uma promissora candidata a antígeno vacinal (Cullen, et al., 2005; Branger, et al., 2005). A atividade protetora de LipL32 foi avaliada através de imunizações nas quais diferentes formas de apresentação do antígeno foram utilizadas: adenovírus (Branger, et al.,2001); vacina de DNA e LipL32 recombinante associada a hidróxido de alumínio (Branger, et al.,2005) e Mycobacterium bovis (BCG) (Seixas, et al.,2007). Estas imunizações induziram proteção parcial contra Leptospira interrogans em modelo de desafio animal (Branger, et al., 2001; Branger, et al., 2005; Seixas, et al., 2007).

\subsubsection{HlyX}

A proteína HlyX codificada pelo gene LIC10325 de L. interrogans sorovar Copenhageni foi anotada como uma hemolisina pela homologia com o gene correspondente de L. borgpetersenii sorovar Hardjo sorotipo hardjobovis, segundo informações do Genbank. O gene LIC10325 possui ainda um ortólogo (LA0378) em L. interrogans sorovar Lai que possui domínios tetratricopeptídeos.

Estudos realizados por Zhang e colaboradores (2005) com E. coli expressando HlyX (LA0378) bem como ensaios realizados pela nossa equipe com a proteína recombinante purificada (Hauk, et al., 2005) mostraram uma atividade hemolítica em placas de ágar sangue de ovelha. Porém, estudos posteriores feitos em nosso laboratório com a proteína purificada não confirmaram esta atividade (Hauk, et al., 2008). Hoje, sabe-se que a atividade hemolítica 
observada pode ser atribuída à presença de contaminação com Triton X-114, utilizado para remover o LPS da proteína HlyX (Hauk, et al., 2008).

Os domínios tetratricopeptídeos são sequências degeneradas de 34 aminoácidos repetidos. Estão envolvidos no controle do ciclo celular, repressão da transcrição, inibição de proteínas quinases, na interação proteína-proteína, entre outras funções (Lamb, et al., 1995). A proteína HlyX possui um peptídeo sinal (posições dos resíduos, 1 a 25 aa) (Figura 7) indicando possivelmente que é secretada ou que seja dirigida para domínios transmembrana, sendo assim, potencialmente exposta ao reconhecimento do sistema imune do hospedeiro. Logo, a proteína HlyX representa um potencial antígeno vacinal para leptospirose, justificando desta forma o interesse por mais estudos relacionados a expressão e caracterização desta proteína.

Informações obtidas a partir do sequenciamento do genoma de L. biflexa indicaram a presença do gene que codifica a proteína HlyX na cepa saprofítica (Picardeau, et al., 2008).

\section{1}

MNRSIILITGFLFICAGLLTAVYQTTIQDEDSKRKNVLEKIKEGEEYLKQTNSKA AEKAVDIFSELSAREIPEEHSFRVKYDMGRALERNQDSLLALGIYRELNQKEGLS

\section{$116 \quad$ TPR1 $148 \quad 152$}

RDERSKVAYSMGNLLLQLNRDEEGKGHLEEVLRISADSKLRSNALSAIADYYMKK TPR2 185

GNYDLSRKNYVLALQEDPENVKARVRWGKSLRRMGKDWSAYDVYDDYAQAGFYFD
231
TPR3
$268 \quad 264$

PEKEKVSSEFRSGILEKARQLYVRKQYYGAIDTFKKALDMGVSSKAEEQALFYIA

\section{$\begin{array}{llll}\text { TPR4 } & 301 & 304 & \text { TPR5 }\end{array}$}

ESYEAIGKSDSALQYLNRVLGNQDGSLDQTALFRKGTIYFKSGKYERAAALFQEA

337

TDKYPDSPVGRKASAWKKESLDQVEDNLHYKQEDKEKSKEDLET

EKLD*

Figura 7 - Sequência de aminoácidos de HlyX. A posição de aminoácidos 1 a 25 , representa a sequência sinal, predita pelo programa computacional SMART. As sequências em vermelho, azul, alaranjado, roxo e cinza estão representando os cinco tetratricopeptídeos presentes na proteína. 


\section{OBJETIVO}

Caracterizar o papel biológico das proteínas LipL32 e HlyX de Leptospira interrogans sorovar Copenhageni

\subsection{Objetivos específicos}

- Obter as proteínas LipL32 e HlyX recombinantes purificadas através da de histidina fusionada no $\mathrm{N}$-terminal das proteínas recombinantes;

- Obter LipL32 sem cauda de histidina para estudos de estrutura tridimensional (cristalografia);

- Caracterizar a atividade biológica de adesina de LipL32 e HlyX;

- Mapear domínios da proteína LipL32 para realizar estudos de imunodominância e atividade biológica;

- Avaliar LipL32 e/ou HlyX como possíveis candidados vacinais contra a leptospirose. 


\section{MATERIAIS E MÉTODOS}

\subsection{Lista de soluções e meios de cultura}

\subsubsection{Soluções utilizadas}

1) Solução tampão TAE (Tris-Acetato-EDTA) 10x: Tris base 400 mM, Ácido acético 190 mM e EDTA 10 mM, pH 7,6.

2) Ficoll Dye 10x: Azul de bromofenol 0,2\% (m/V), xileno cianol 0,42\% (m/V) e glicerol $50 \%(\mathrm{~V} / \mathrm{V})$.

3) Solução tampão de amostra para SDS-PAGE 10x: Tris-HCl 1 M, pH 6,8, SDS 10\% (m/V), azul de bromofenol 0,5\% (m/V), glicerol 50\% (V/V) e $\beta$-mercaptoetanol 1,43 M.

4) Solução tampão de lavagem dos corpúsculos de inclusão (1 M uréia): Tris-HCl 50 mM, pH 8,0, $\mathrm{NaCl} 500 \mathrm{mM}$, uréia $1 \mathrm{M}$ e $\beta$-mercaptoetanol $10 \mathrm{mM}$.

5) Solução tampão de solubilização dos corpúsculos de inclusão (8 M uréia): Tris-HCl 50 $\mathrm{mM}, \mathrm{pH} 8,0, \mathrm{NaCl} 500 \mathrm{mM}$, uréia $8 \mathrm{M}$ e $\beta$-mercaptoetanol $10 \mathrm{mM}$.

6) Solução tampão de ligação à coluna I (solução de equilíbrio): Tris-HCl 150 mM, pH 8,0.

7) Solução tampão de ligação à coluna II (solução de equilíbrio): 20 mM trietanolamina, pH 7,8 .

8) Solução tampão de diálise: Tris-HCl 150 mM, pH 8,0.

9) Solução tampão Tris-glicina 5x: Tris base 1,5\% (m/V), glicina 9,4\% (m/V) e SDS 0,5\% $(\mathrm{m} / \mathrm{V})$.

10) Solução corante de SDS-PAGE: Comassie Blue Brillant $0,25 \%(\mathrm{~m} / \mathrm{V})$, etanol $40 \%(\mathrm{~V} / \mathrm{V})$ e ácido acético $10 \%(\mathrm{~V} / \mathrm{V})$.

11) Solução descorante de SDS-PAGE: Etanol 30\% (V/V) e ácido acético 10\% (V/V).

12) Solução secante de SDS-PAGE: Etanol 50\% (V/V) e ácido acético 10\% (V/V).

13) PBS (Solução tampão fosfato): $\mathrm{NaCl}$ 1,37 M, KCl 27 mM, Na $\mathrm{HPO}_{4} 100$ mM, $\mathrm{KH}_{2} \mathrm{PO}_{4}$ $14 \mathrm{mM}, \mathrm{pH} 7,4$.

14) PBS-T: PBS e Tween ${ }^{\circledR} 200,05 \%$ (V/V).

15) Solução tampão carbonato-bicarbonato: $\mathrm{Na}_{2} \mathrm{CO}_{3} 50$ mM e $\mathrm{NaHCO}_{3} 50 \mathrm{mM}$, pH 9,6.

16) Solução tampão citrato-fosfato: Citrato de sódio $100 \mathrm{mM}$ e fosfato de sódio monobásico $\left(\mathrm{NaH}_{2} \mathrm{PO} 4\right) 300 \mathrm{mM}$.

17) Solução tampão de transferência de Western blot 5x: Tris-glicina 5x e SDS $10 \%(\mathrm{~m} / \mathrm{V})$. 


\subsubsection{Meios de cultura utilizados}

1) Meio líquido 2YT: Triptona $1,6 \%(\mathrm{~m} / \mathrm{V})$, extrato de levedura $1 \%(\mathrm{~m} / \mathrm{V})$ e $\mathrm{NaCl} 0,5 \%$ $(\mathrm{m} / \mathrm{V})$.

2) Meio sólido 2YT-ágar: meio 2YT e bactoágar 1,5\% (m/V).

3) Meios sólido ou líquido 2YT-amp: meio 2YT-ágar ou 2YT e $100 \mu \mathrm{g} / \mathrm{mL}$ de ampicilina.

4) Meio sólido ou líquido 2YT-amp/clo: meio 2YT-ágar ou 2YT e $100 \mu \mathrm{g} / \mathrm{mL}$ de ampicilina e $30 \mu \mathrm{g} / \mathrm{mL}$ de cloranfenicol

5) Meio líquido 2YT/ON: Triptona $1,6 \%(\mathrm{~m} / \mathrm{V})$ e extrato de levedura $1 \%(\mathrm{~m} / \mathrm{V})$.

6) Meio sólido 2YT/ON-ágar: meio 2YT/ON e bactoágar 1,5\% (m/V).

7) Meio sólido ou líquido 2YT/ON-amp: meio 2YT/ON-ágar ou 2YT/ON e 100 g/mL de ampicilina.

8) Meio líquido M9/ON: $\mathrm{Na}_{2} \mathrm{HPO}_{4}$ 0,3 M, $\mathrm{KH}_{2} \mathrm{PO} 40,17 \mathrm{M}, \mathrm{MgSO}_{4} 1 \mathrm{M}$, glicose $20 \%, \mathrm{CaCl}_{2}$ $1 \mathrm{M} \mathrm{e} \mathrm{NH}_{4} \mathrm{Cl} 0,5 \mathrm{M}$.

9) Meio líquido EMJH (Difco®-USA): Di-sódio fosfato 0,1\% (m/V), fosfato de sódio monobásico $0,03 \%(\mathrm{~m} / \mathrm{V}), \mathrm{NaCl} 0,1 \%(\mathrm{~m} / \mathrm{V})$, cloreto de amônio $0,025 \%(\mathrm{~m} / \mathrm{V})$ e tiamina $0,0005 \%(\mathrm{~m} / \mathrm{V})$.

10) Meio líquido EMJH enriquecido: EMJH base $0,23 \%(\mathrm{~m} / \mathrm{V})$, peptona $0,03 \%(\mathrm{~m} / \mathrm{V})$, extrato de carne $0,02 \%(\mathrm{~m} / \mathrm{V})$, soro de coelho estéril $10 \%$, L-asparagina $0,015 \%(\mathrm{~m} / \mathrm{V}), \mathrm{CaCl}_{2}$ $0,001 \%(\mathrm{~m} / \mathrm{V}), \mathrm{MgCl}_{2}$ 0,001\% (m/V), piruvato de sódio 0,001\% (m/V). 


\subsection{Vetores utilizados}

Os vetores utilizados para as subclonagens de produtos de PCR foram: $\mathrm{pCR}^{\mathrm{R}} 4 \mathrm{Blunt}-$ TOPO (Invitrogen ${ }^{\circledR}$ ), pENTR TOPO (Invitrogen ${ }^{\circledR}$ ) e pGEM-T easy $\left(\right.$ Promega $\left.^{\circledR}\right)$. Os vetores de expressão em E. coli utilizados neste trabalho foram pDEST17 (Invitrogen ${ }^{\circledR}$ ) e pAE (Ramos, et al.,2004) (Figura 8).

Anteriormente a este trabalho, lipL32 já havia sido clonada por Gamberini e colaboradores (2005), utilizando-se o sistema Gateway (Invitrogem). O vetor pENTR TOPO contendo lipL32 foi transferido por recombinação para o vetor de expressão pDEST17 $\left(\right.$ Invitrogen ${ }^{\circledR}$ ), pela ação da LR clonase. O vetor pDEST17 contém o promotor do fago T7 (T7), sítio de ligação de ribossomo (RBS), códon ATG de iniciação e sequência codificante para seis histidinas (6xHis), que são fusionadas na porção $\mathrm{N}$-terminal da proteína recombinante, facilitando a purificação desta através de cromatografia de afinidade a metais bivalentes. Dois sítios de recombinação, a $t \mathrm{R} 1$ e at $t \mathrm{R} 2$, flanqueiam o gene de resistência a cloranfenicol. Estas sequências são trocadas pelas sequências, a $t \mathrm{~L} 1$ e a $t \mathrm{~L} 2$, presentes no “clone de entrada" pela reação com a enzima LR clonase. As sequências de DNA clonadas no pDEST17 podem ser expressas pela ação da T7 RNA polimerase em E. coli.

O vetor de expressão pAE, desenvolvido por Ramos e colaboradores (2004) possui a origem de replicação do vetor pUC18, sendo também constituído pelo promotor do fago T7, um sítio de ligação de ribossomo (RBS), sequência codificadora para seis histidinas, sítio múltiplo de clonagem (MCS) e terminador de transcrição (T7 term). Este vetor possui sequência codificadora para $\beta$-lactamase, conferindo resistência à ampicilina. A presença da cauda de histidina neste vetor também é utilizada como estratégia de purificação através de cromatografia de afinidade a metais bivalentes. 


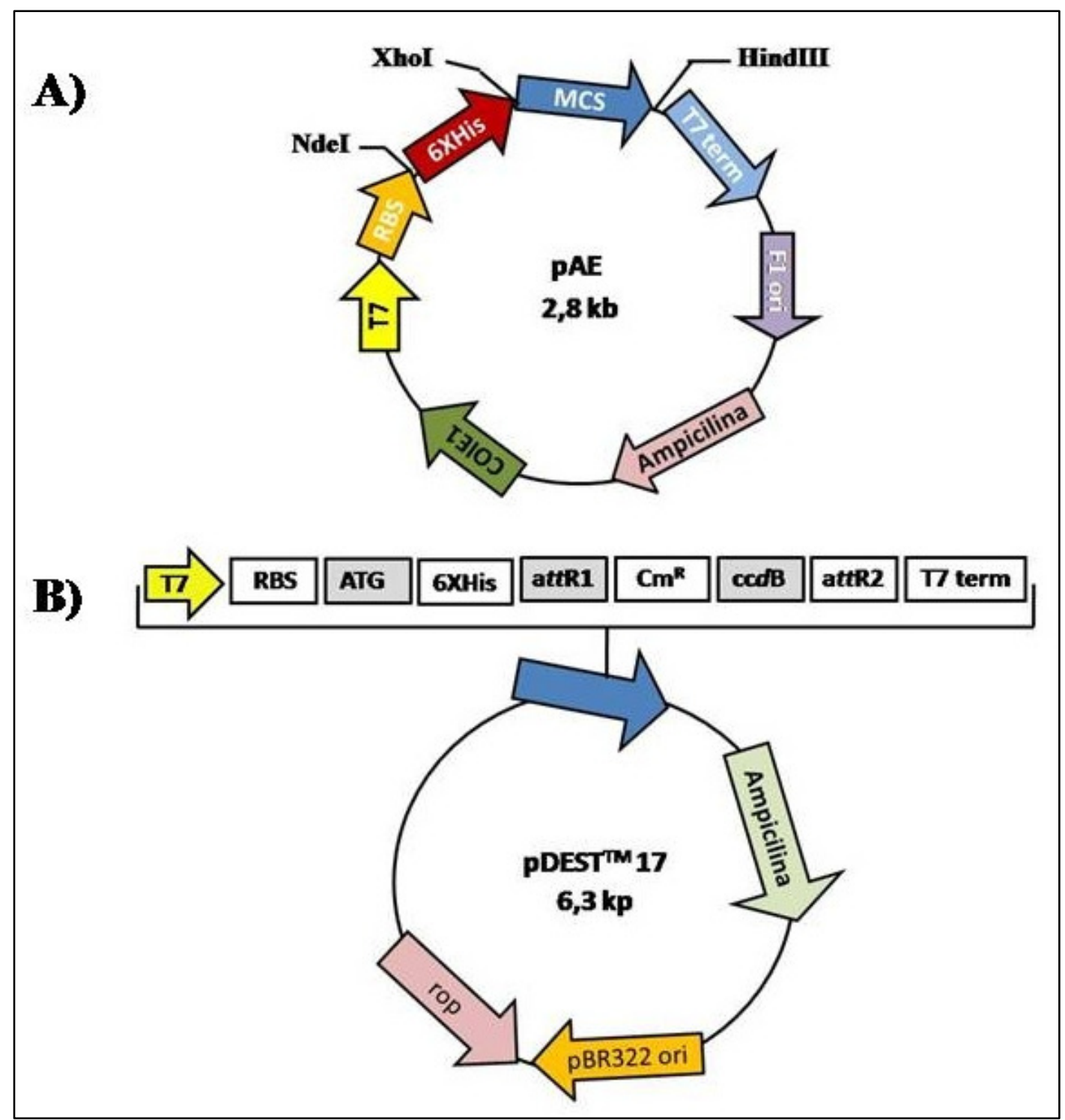

Figura 8 - Representação esquemática dos vetores de expressão em E. coli, pAE (A) e pDEST ${ }^{\mathrm{TM}} 17$ (B). Ambos os vetores adicionam uma sequência contendo seis resíduos de histidinas no Nterminal da proteína recombinante. $O$ vetor $\mathrm{pAE}$ adiciona a sequência: MHHHHHHLE e o vetor $\mathrm{pDEST}^{\mathrm{TM}} 17$ adiciona a sequência: MSYYHHHHHHLESTSLYKKAGSAAAPF no N-terminal da proteína heteróloga. 


\subsection{Linhagens bacterianas}

As cepas de Leptospira $^{(1)}$ (L. interrogans sorovares Canicola, Pyrogenes, Pomona, Autumnalis, Hardjo, Brastilava, Copenhageni e Icterohaemorragiae, L. biflexa sorovar Patoc e L. kirchneri) foram cultivadas por 7 dias a $28{ }^{\circ} \mathrm{C}$ sob condições aeróbicas em meio líquido EMJH enriquecido. A linhagem virulenta L. interrogans sorovar Copenhageni (ATCC BAA1198) também foi cultivada nas condições citadas acima, porém para que a virulência desta linhagem fosse mantida foram necessárias passagens periódicas por hamsters.

A linhagem Escherichia coli $\mathrm{DH} 5 \alpha^{\mathrm{TM}}\left(\right.$ Invitrogen $\left.^{\circledR}\right)$ foi utilizada para as subclonagens dos produtos de PCR e para as clonagens dos genes de interesse no vetor de expressão. E. coli DH5 $\alpha$ foi cultivada em meio 2 YT-amp a $37^{\circ} \mathrm{C}$ por $16 \mathrm{~h}$.

Para a etapa de expressão das proteínas recombinantes foram utilizadas as cepas de $E$. coli BL21 SI $\left(\mathrm{Gibco}_{\mathrm{BRL}}{ }^{\circledR}\right)$ ou E. coli BL21 (DE3) star [plysS] $\left(\right.$ Novagen $\left.^{\circledR}\right)$. E. coli BL21 SI foi cultivada em meio 2 YTON-amp a $30{ }^{\circ} \mathrm{C}$ por 16 h; já a E. coli BL21 (DE3) star [plysS] foi cultivada em meio 2 YT-amp/clo a $37^{\circ} \mathrm{C}$ por $16 \mathrm{~h}$.

A cepa E. coli BL21(SI) contém o gene da T7 RNA polimerase sob o controle da ação do promotor proU de E. coli responsivo a osmolaridade, induzível por $\mathrm{NaCl}$ (Bhandari e Gowrishankar, 1997). E. coli BL21 (DE3) star [plysS] possui o promotor induzível por IPTG e um plasmídeo (pLysS) que confere resistência a cloranfenicol e produz T7 lisozima que se liga a T7 RNA polimerase, reduzindo os níveis basais de expressão do gene de interesse, sendo desta forma apropriado para a expressão de proteínas tóxicas. Esta cepa possui o lisógeno do $\lambda$ DE3 que carrega uma cópia cromossomal do gene T7 RNA polimerase que está sob o controle do promotor lacUV5.

\subsection{Soros de pacientes com leptospirose}

Os soros de pacientes diagnosticados com leptospirose foram obtidos da coleção de soros do Instituto Adolfo Lutz, São Paulo, Brasil. Duas amostras de soro correspondendo à fase aguda e à fase convalescente da infecção foram colhidas de 12 pacientes. Todos os pacientes foram hospitalizados com sintomas de leptospirose. Os dados referentes aos soros

\footnotetext{
${ }^{(1)}$ As cepas de Leptospira foram gentilmente fornecidas pelo Dr Sílvio Arruda Vasconcellos, da Faculdade de Medicina Veterinária e Zootecnia da Universidade de São Paulo (USP).
} 
dos pacientes, títulos de MAT, início dos sintomas e sorovar infectante estão disponíveis na tabela 3 .

\subsection{Amplificação dos genes $h l y \mathrm{X}$, lipL32 e dos fragmentos, N-terminal, intermediário e C-terminal de LipL32}

Os genes hlyX e lipL32(2) foram amplificados por PCR utilizando-se como molde o DNA genômico de L. interrogans sorovar Copenhageni (linhagem Fiocruz L1-130). Para as amplificações foram utilizados $50 \mu \mathrm{l}$ de reação contendo $20 \mathrm{mM}$ de cada oligonucleotídeo, $200 \mathrm{mM}$ de cada dNTP e cerca de $60 \eta \mathrm{g}$ de DNA genônico, $1 \mu 1$ de Platinum Pfx DNA polimerase $400 \mathrm{U} / \mu \mathrm{l}$, tampão da $P f x$ DNA polimerase $1 \mathrm{X}$ (fornecido pelo fabricante pronto para uso) e $50 \mathrm{mM} \mathrm{MgSO}_{4}$.

A reação de amplificação de $h l y \mathrm{X}$ foi realizada com temperatura de desnaturação de $94{ }^{\circ} \mathrm{C}$ durante 7 min e 30 ciclos de: $94{ }^{\circ} \mathrm{C}$ por $30 \mathrm{~s} ; 47{ }^{\circ} \mathrm{C}$ por $30 \mathrm{~s} ; 68{ }^{\circ} \mathrm{C}$ de 2 min, finalizando com $68{ }^{\circ} \mathrm{C}$ durante 5 min. Para as reações de amplificação de lipL32 e seus fragmentos foi utilizada a mesma condição, ou seja, temperatura de desnaturação de $95{ }^{\circ} \mathrm{C}$ durante 3 min e 35 ciclos de: $95{ }^{\circ} \mathrm{C}$ por $30 \mathrm{~s} ; 50{ }^{\circ} \mathrm{C}$ por $30 \mathrm{~s} ; 68{ }^{\circ} \mathrm{C}$ de $1 \mathrm{~min}$, finalizando com $68{ }^{\circ} \mathrm{C}$ durante 2 min.

Os fragmentos do gene lipL32 também foram amplificados por PCR, porém o DNA molde utilizado foi a construção lipL32/pGEM-T easy, obtida na subclonagem. Para a amplificação dos fragmentos do gene lipL32 que correspondem aos fragmentos protéicos de interesse, $\mathrm{N}$-terminal, intermediário e C-terminal, foram utilizadas as mesmas condições de amplificação utilizadas para lipL32. Todos os oligonucleotídeos utilizados nas reações de amplificação estão presentes na tabela 1 .

Nas figuras 9 e 10 estão representadas as sequências nucleotídicas e de aminoácidos, nas quais estão demonstradas as regiões dos genes hlyX, lipL32 e os fragmentos de lipL32 (N-terminal, intermediário e C-terminal), respectivamente, que foram amplificadas e posteriormente clonados.

\footnotetext{
(2) lipL32 está sendo novamente clonada para que possa ser expressa sem a fusão de seis histidinas no Nterminal. A ausência da cauda de histidina é importante em estudos de estrutura terciária.
} 
Tabela 1 - Oligonucleotídeos utilizados para a amplificação dos genes hlyX, lipL32 6xHis, lipL32 e seus fragmentos N-terminal, intermediário e C-terminal.

\begin{tabular}{|c|c|}
\hline Primers & Sequência \\
\hline HlyX $_{F}$ & 5'-TACTCGAGGTGTATCAAACTACGATTCAAGAC-3' \\
\hline HlyX $_{R}$ & 5'-AAGAATTCTCAATCCAATTTTTCGGTTTCC-3' \\
\hline LipL32 6xHis ${ }_{\mathrm{F}}{ }^{*}$ & 5'-CACCGGTGCTTTCGGTGGTCTG-3' \\
\hline LipL32 $6 \mathrm{xHis}_{\mathrm{R}}{ }^{*}$ & 5' - ATTACTTAGTCGCGTCAGAAGC-3' \\
\hline LipL32 $2_{F}$ & 5'--CTCGAGCATATGGGTGCTTTCGGTGGTCTG-3' \\
\hline LipL32 ${ }_{R}$ & 5'-AAGCTTACTTAGTCGCGTCAGAAGC-3' \\
\hline $\mathrm{N}$-terminal ${ }_{F}$ & 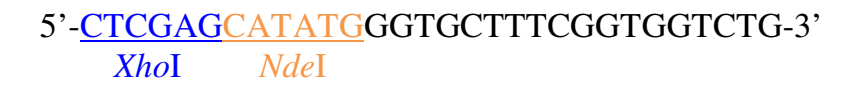 \\
\hline $\mathrm{N}_{\text {-terminal }} \mathrm{R}$ & 5'- $\frac{\text { AAGCTTTTAAGCGATTACGGCAGGAAT-3' }}{\text { HindIII }}$ \\
\hline Intermediário $_{\mathrm{F}}$ & 5'-CTCGAGATGGAAATGGGAGTTCGTATG-3' \\
\hline Intermediário $_{R}$ & 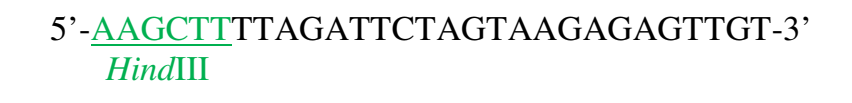 \\
\hline C-terminal $F$ & 5'- $\frac{\text { CTCGAGATGAAGATCCCTAATCCTCCA-3' }}{\text { XhoI }}$ \\
\hline C-terminal $\mathrm{R}_{\mathrm{R}}$ & 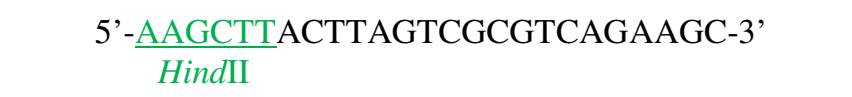 \\
\hline
\end{tabular}

*Oligonucleotídeos desenhados por Gamberini, et al., 2005, com a inserção de 4 bases (CACC) "foward" com o objetivo de permitir a clonagem direcional no sistema Gateway (Invitrogen ${ }^{\circledR}$ ). O produto de PCR gerado contendo as 4 bases (CACC) na região 5' é reconhecido por uma sequência "overhang" (GTGG) presente no vetor pENTR TOPO (vetor de subclonagem), sob a ação da topoisomerse, que anela as bases complementares adicionadas e estabiliza o produto de PCR na orientação correta. 
HlyX $\mathrm{X}_{\mathrm{F}}:$ ' '-TACTCGAGGTGTATCAAACTACGATTCAAGAC-3' XhoI

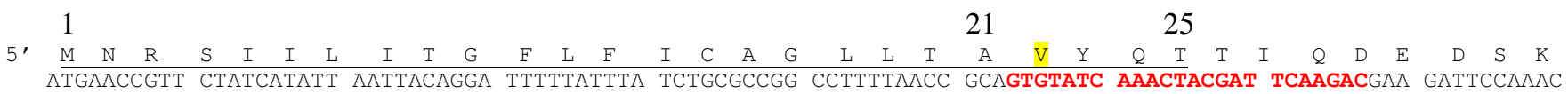

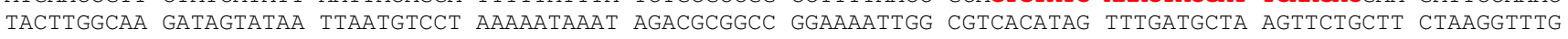

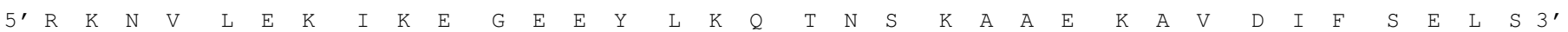

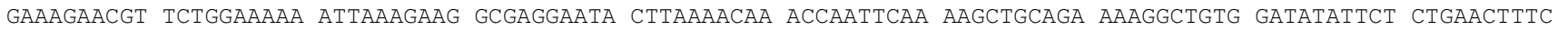

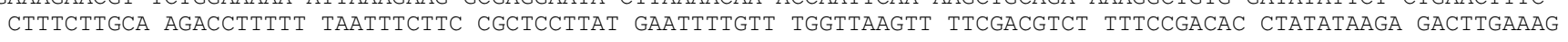

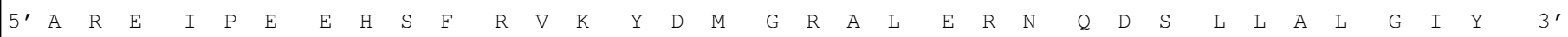

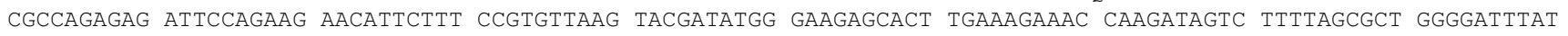

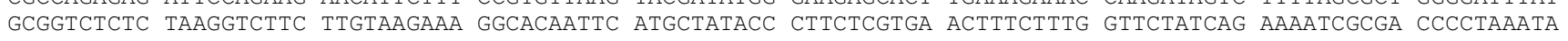

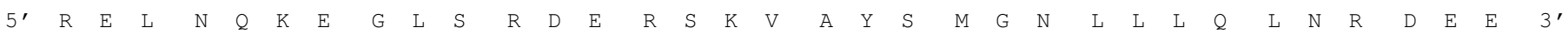

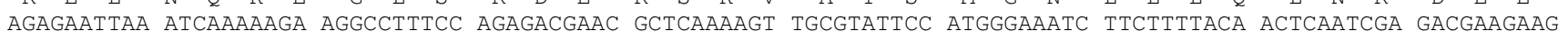

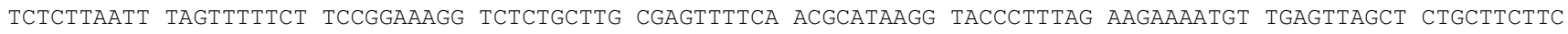

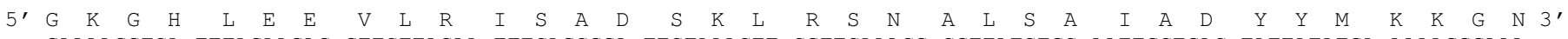

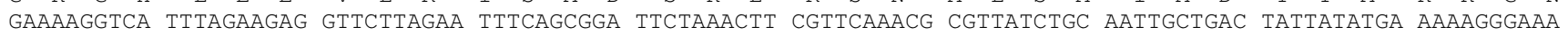

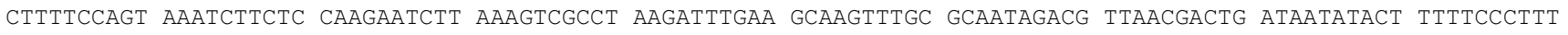

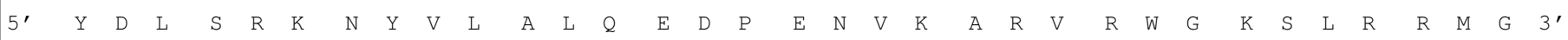
TTATGATCTT TCTCGCAAAA ATTACGTCCT CGCCCTCCAG GAAGATCCTG AAAATGTAAA AgCCAGAgTT CGTTGGGGAA AATCTTTACG CAGAATGGGT

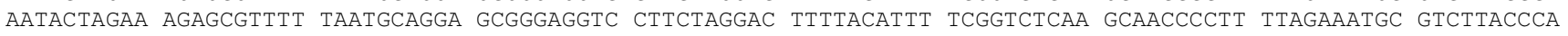

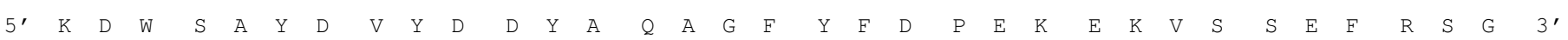

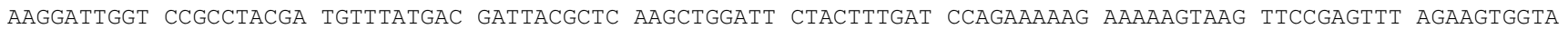

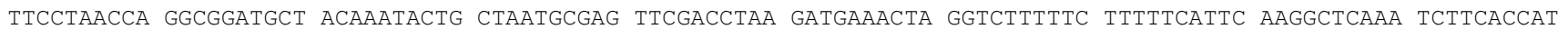

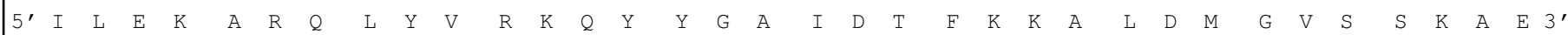

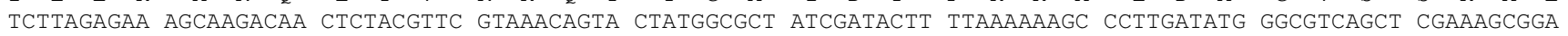
AGAATCTCTT TCGTTCTGTT GAGATGCAAG CATTTGTCAT GATACCGCGA TAGCTATGAA AATtTTtTCG GGAACTATAC CCGCAGTCGA GCTTTCGCCT

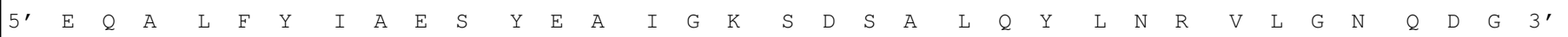

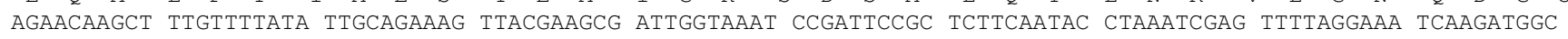
TCTTGTTCGA AACAAAATAT AACGTCTTTC AATGCTTCGC TAACCATTTA GGCTAAGGCG AGAagtTATG GATTTAGCTC AAAATCCTTT AgtTCTACCG

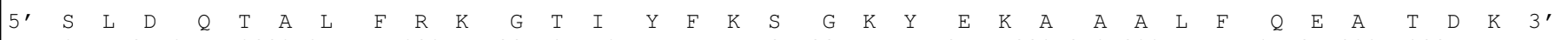

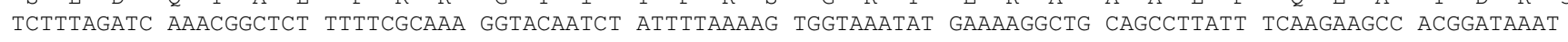

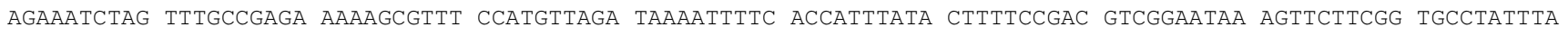

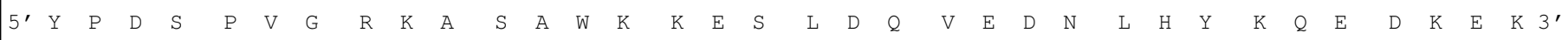

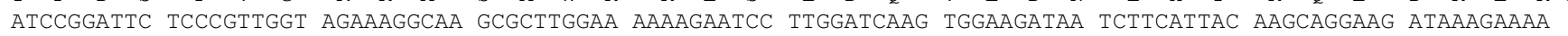

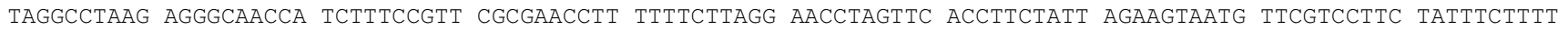

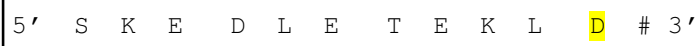

AAgTAAAgAg GATCTAGAAA CCGAAAAATT GGATTGA

TTCATTTCTC CTAGATCTTT GGCTTTTTAA CCTAACT

HlyX $\mathrm{R}_{\mathrm{R}}$ 3'- СтTTGGCTTTTTAACCTAACTCTTAAGAA-5'

Figura 9 - Sequência de nucleotídeos (1137 pb) e aminoácidos de HlyX (378 aa), e os oligonucleotídeos utilizados na amplificação do gene. A sequência sinal predita pelo programa computacional SMART está sublinhada. A amplificação de $h l y \mathrm{X}$ foi realizada a partir da posição 22 aa, excluindo-se grande parte da provável sequência sinal. 


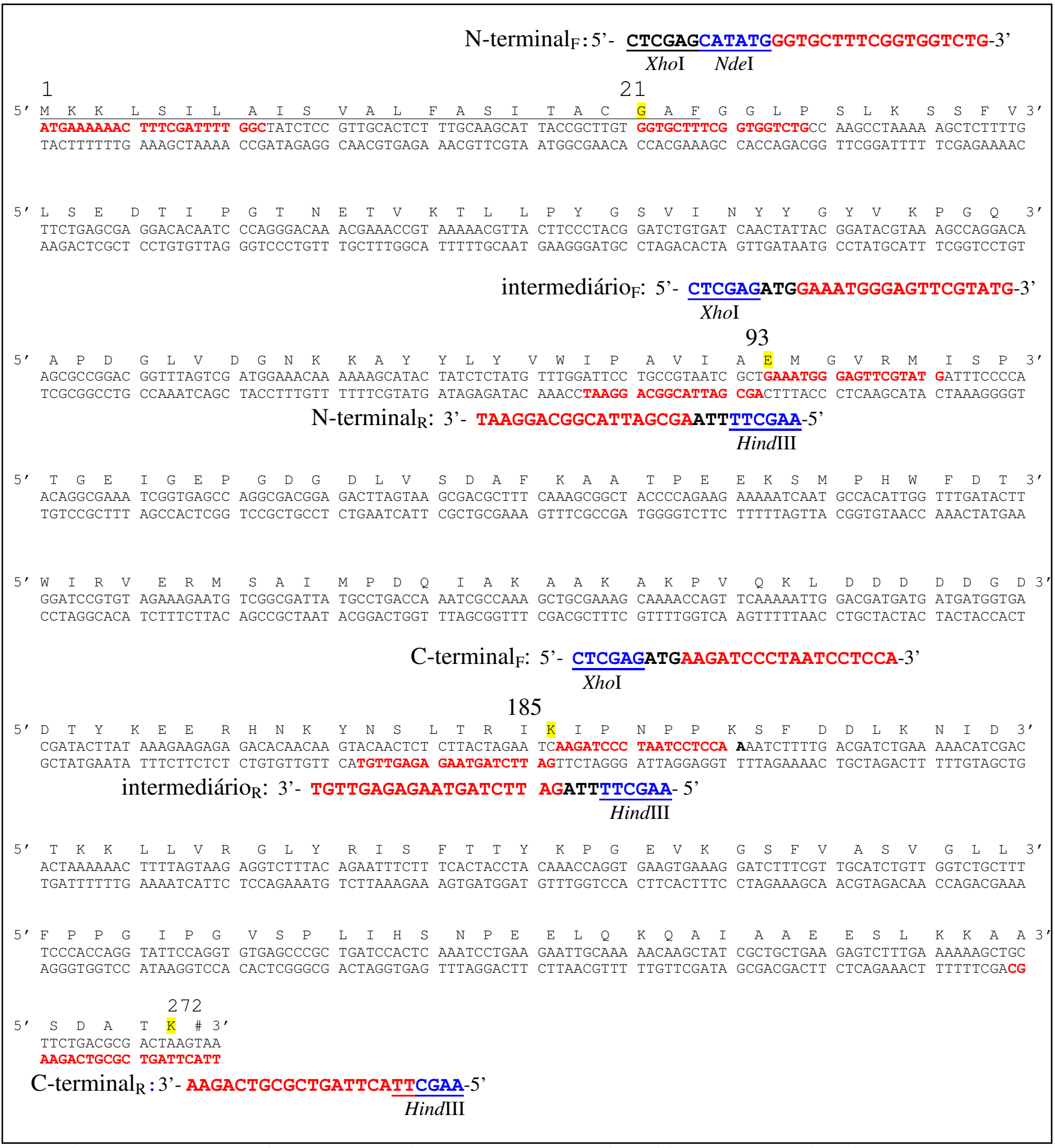

Figura 10 - Sequência de nucleotídeos (819 pb) e aminoácidos (272 aa) de LipL32, e os oligonucleotídeos utilizados nas amplificações de LipL32 e seus fragmentos. Na figura pode ser visualizado o esquema de amplificação de lipL32 e seus fragmentos, Nterminal, intermediário e C-terminal. Para lipL32 a amplificação foi realizada utilizando-se oligonucleotídeos a partir da posição 21 aa, excluindo-se a região do "lipobox", que termina na cisteína. Para o mapeamento de LipL32, foram desenhados três pares de oligonucleotídeos. Foram amplificados segmentos de DNA correspondentes a região $\mathrm{N}$-terminal, aminoácidos 21 a 92 aa, para a região do fragmento intermediário de 93 a 184 aa e para a região C-terminal de 185 a 272 aa. 


\subsection{Subclonagem dos produtos da PCR}

Para a subclonagem, os produtos da PCR foram ligados nos vetores disponíveis no laboratório. O produto da amplificação de hlyX foi ligado ao vetor $\mathrm{pCR}^{\mathrm{R}} 4 \mathrm{Blunt}-\mathrm{TOPO}$ e os demais produtos, lipL32 e seus fragmentos, foram ligados no vetor pGEM-T easy. Para a reação de ligação dos insertos aos vetores de subclonagem, os produtos de PCR foram submetidos a uma migração eletroforética em um gel de agarose 1\%, tampão TAE 1X e brometo de etídio 0,5 g/L (Sambrook, et al., 1989). Após a migração, as bandas referentes aos fragmentos amplificados foram purificadas do gel utilizando-se o kit "GFX ${ }^{\mathrm{TM}}$ Gel Band Purification" (GE HealthCare ${ }^{\circledR}$ ). Após a purificação das bandas, somente hlyX pôde ser submetido à reação de ligação no vetor $\mathrm{pCR}^{\mathrm{R}} 4 \mathrm{Blunt}-\mathrm{TOPO}$. Os demais insertos precisaram ser submetidos a uma reação de adenilação, pois o vetor pGEM-T easy, no qual foram ligados, é fornecido pelo fabricante na forma linear, com um resíduo de timidina nas extremidades 3'. Diferentemente da Taq polimerase que faz a adenilação na extremidade 3', a Platinum Pfx DNA polimerase, não apresenta esta atividade, requerendo esta reação adicional.

\subsubsection{Reação de adenilação}

Para cada reação de $50 \mu 1$ foram utilizados cerca de $50 \eta \mathrm{g}$ de lipL32 e seus fragmentos correspondentes ao N-terminal, intermediário e C-terminal, tampão da Taq polimerase 1X, $\mathrm{MgCl}_{2} 50 \mathrm{mM}$, dATP $20 \mathrm{mM}, 2$ unidades (U) de Taq polimerase e 0,5 $\mu \mathrm{lde} \mathrm{H}_{2} \mathrm{O}$. As reações de adenilação foram realizadas a $72{ }^{\circ} \mathrm{C}$ por $30 \mathrm{~min}$, utilizando-se um termociclador.

\subsubsection{Reação de ligação}

Cerca de $50 \eta \mathrm{g}$ de hlyX, lipL32 e seus fragmentos foram incubados a $16^{\circ} \mathrm{C}$ por 16 horas com $25 \eta \mathrm{g}$ do $\mathrm{pCR}^{\mathrm{R}} 4 \mathrm{Blunt}-\mathrm{TOPO}$ para $h l y \mathrm{X}$ e $25 \eta \mathrm{g}$ do vetor pGEM-T para os insertos adenilados, $1 \mu \mathrm{L}$ de $\mathrm{T}_{4}$ DNA ligase $400 \mathrm{U} / \mu \mathrm{L}$ (Invitrogen ${ }^{\circledR}$ ) na presença da solução tampão fornecida pelo fabricante da enzima num volume total de $20 \mu \mathrm{L}$. 


\subsection{Transformação de bactérias competentes}

As bactérias $E$. coli quimiocompetentes (competência por $\mathrm{Ca}^{2+}$ ) foram preparadas de acordo com o protocolo previamente descrito (Sambrook, et al., 1989). Foram adicionados a $50 \mu \mathrm{l}$ de bactérias competentes $E$. coli $\mathrm{DH} 5 \alpha, 20 \mu \mathrm{l}$ do produto da reação de ligação. A mistura foi incubada em gelo por 30 minutos e em seguida submetida a choque térmico de 42 ${ }^{\circ} \mathrm{C}$ por 2 minutos. Após 5 minutos no gelo, adicionaram-se $300 \mu \mathrm{l}$ de meio $2 \mathrm{YT}$ e deixou-se incubando a $37{ }^{\circ} \mathrm{C}$ por 50 minutos. O volume total dessa mistura foi dividida e plaqueada em meio sólido (2YT-ágar) contendo $100 \mu \mathrm{g} / \mathrm{ml}$ de ampicilina. As placas contendo as bactérias com plasmídeo foram incubadas por 16 horas a $37^{\circ} \mathrm{C}$.

\subsection{Análise dos clones positivos através de extração com fenol-clorofórmio}

Os clones resistentes a ampicilina foram selecionados e inoculados em $3 \mathrm{ml}$ de meio 2YT contendo ampicilina. Retirou-se uma alíquota de $200 \mu \mathrm{l}$ de cultura, crescida por 16 horas. Centrifugou-se por 4 minutos a $13.400 \mathrm{X} \mathrm{g}$ e descartou-se o meio de cultura. Adicionou-se ao precipitado bacteriano $40 \mu \mathrm{l}$ de Ficoll Dye 2x, $15 \mu \mathrm{l}$ de uma solução 1:1 de fenol:clorofórmio $(\mathrm{V} / \mathrm{V})$. A mistura foi agitada por 1 minuto e centrifugada por 1 minuto a $13.400 \mathrm{X}$ g. Foram aplicados em um gel de agarose $1 \%(\mathrm{~m} / \mathrm{V}) 10 \mu \mathrm{l}$ do sobrenadante dessa mistura, contendo DNA genômico e plasmidial e RNA.

A banda do plasmídeo do controle negativo (plasmídeo sem inserto) deve ter maior mobilidade que os plasmídeos dos clones positivos, devido à diferença de massa molecular entre eles. Portanto, os clones que migraram menos em relação ao controle negativo, foram escolhidos para serem purificados (Beuken, et al., 1998). Após a purificação dos plasmídeos estes foram sequenciados pelo método de terminação da cadeia (Sanger, et al., 1977), usando o sequenciador de DNA ABI 3100 (Applied Biosystems do Brasil) ou submetidos a análise de restrição com endonucleases.

\subsubsection{Purificação dos plasmídeos}

Para a purificação dos plasmídeos a partir dos clones positivos foram utilizados os mesmos cultivos, usados para a pesquisa de clones positivos. A fração de cultura restante contendo os clones positivos escolhidos foi aliquotada e o precipitado bacteriano foi obtido 
por centrifugação com posterior descarte do meio. As etapas subseqüentes foram realizadas usando o kit "Promega's Wizard Plus Miniprep" conforme instruções do fabricante.

\subsection{Clonagem no vetor de expressão}

Para a clonagem dos insertos no vetor pAE, foi necessário submeter os plasmídeos positivos e o vetor pAE vazio à digestão com enzimas de restrição que "flanqueiam" os insertos de interesse. Para $h l y \mathrm{X}$ foi realizada a digestão do clone positivo obtido da subclonagem e do vetor pAE vazio com as enzimas de restrição XhoI e EcoRI, inseridas pelo primer foward e primer reverse, respectivamente. Os fragmentos do gene lipL32, N-terminal, intermediário e C-terminal foram todos desenhados com oligonucleotídeos contendo os sítios de restrição XhoI no primer foward e HindIII no primer reverse, portanto o produto destas subclonagens foram digeridos com estas enzimas, assim como o pAE vazio.

Com relação a lipL32, o primer foward foi desenhado com dois sítios de restrição para permitir que a proteína pudesse ser clonada com e sem a sequências codificadora das seis histidinas presentes no vetor pAE. Portanto, o primer foward, possui os sítios XhoI e NdeI, em virtude do vetor pAE possuir no sítio mútiplo de clonagem (MCS) a sequência nucleotídica CATATG (NdeI). Desta forma, lipL32/pGEM-T easy e o vetor pAE vazio foram digeridos com as enzimas XhoI e HindIII, esta última adicionada pelo primer reverse ao produto de PCR. Os produtos das digestões com as endonucleases foram submetidos a eletroforese em um gel de agarose $1 \%$, para cortar a banda relativa ao fragmento linearizado com o tamanho esperado. Foram realizados novamente os passos 3.6.2 (ligação dos insertos agora no vetor de expressão) e 3.7. A confirmação das clonagens no pAE foi feita através da comparação da mobilidade, por eletroforese em gel de agarose, dos plasmídeos e do vetor pAE vazio (Beuken, et al., 1998), como descrito no item 3.8.

Os DNAs de alguns clones de cada construção foram purificados e seqüenciados com oligonucleotídeos adequados para verificar se a clonagem ocorreu do modo esperado. Após a confirmação dos clones positivos com as diferentes construções estas foram transformadas em cepas de E. coli utilizadas para expressão de proteínas. A construção lipL32/pAE precisou ainda ser submetida a uma nova digestão com a enzima $N d e$ I para a remoção das seis histidinas presentes na construção. 


\subsection{Expressão das proteínas recombinantes em $E$. coli}

\subsubsection{Expressão de LipL32 6xHis, LipL32 e do fragmento C-terminal de LipL32 em E. coli BL21 (SI)}

Bactérias competentes E. coli BL21(SI) foram transformadas com as construções lipL32/pDEST17, lipL32/pAE ou C-terminal_lipL32/pAE, semelhantemente ao realizado com a linhagem bacteriana DH5 $\alpha$, exceto pelo fato de que tanto em meio sólido (2YTONágar-amp) quanto em meio líquido (2YTON-amp), a linhagem bacteriana (SI) cresceu a $30^{\circ} \mathrm{C}$ em meio sem $\mathrm{NaCl}$, pois este é o indutor do promotor desta cepa de expressão. Foi escolhida uma das inúmeras colônias resistentes à ampicilina e esta foi inoculada em $50 \mathrm{ml}$ de meio líquido 2YTON (meio 2YT sem $\mathrm{NaCl}$ ) contendo $100 \mu \mathrm{g} / \mathrm{ml}$ de ampicilina (2YTON-amp), incubada a $30^{\circ} \mathrm{C}$ por 16 horas sob agitação. Os $50 \mathrm{ml}$ de cultura crescida durante $16 \mathrm{~h}$ ( préinóculo ) foram adicionados em 1 litro de meio 2 YTON e crescidos a $30{ }^{\circ} \mathrm{C}$ sob agitação.

Quando a $\mathrm{OD}_{600}$ atingiu 0,6 (aproximadamente 3 horas de crescimento), aliquotou-se 1 $1 \mathrm{ml}$ de cada cultura (para análise do ponto não induzido por SDS-PAGE) e em seguida foi adicionado $300 \mathrm{mM} \mathrm{NaCl}$ na cultura de células. Procedeu-se então a uma incubação de 3 horas a $30{ }^{\circ} \mathrm{C}$ sob agitação. Foi aliquotado $1 \mathrm{ml}$ de cada cultura para o ponto induzido ser analisado por eletroforese. As amostras de $1 \mathrm{ml}$ que foram aliquotadas para a verificação da expressão foram centrifugadas para a remoção do meio de cultura e ressuspendidas em $100 \mu 1$ de água e $25 \mu 1$ de tampão SDS 5X. As amostras foram agitadas vigorosamente e os extratos gerados foram aquecidos a $96{ }^{\circ} \mathrm{C}$ por 30 minutos para a degradação do DNA genômico bacteriano. Os lisados foram analisados por SDS-PAGE $15 \%$ para as construções lipL32/pDEST17 e lipL32/pAE. Para a construção C-terminal_lipL32/pAE, os lisados foram analisados por SDS-PAGE 18\%. As culturas de 1 litro de células foram centrifugadas por 10 minutos a $3786 \mathrm{X}$ g e os precipitados bacterianos obtidos foram ressuspendidos em $100 \mathrm{ml}$ de tampão 150 mM Tris-HCl, pH 8.0, agitados vigorosamente até a homogeneização, e logo em seguida congelados a $-20{ }^{\circ} \mathrm{C}$ para facilitar o rompimento das células bacterianas. Após o descongelamento das misturas, estas foram lisadas por pressão no French Pressure ${ }^{\circledR}$.

Os lisados foram centrifugados, para separar a fração solúvel e insolúvel de proteínas. Em todas as expressões das construções realizadas somente a fração solúvel foi coletada, os corpúsculos de inclusão foram descartados. 


\subsubsection{Expressão de LipL32 com selênio-metionina (Se-M) em meio mínimo (M9 ON)}

Para a expressão de LipL32 contendo metioninas marcadas com selênio, bactérias competentes E. coli BL21(SI) contendo o plasmídeo lipL32/pAE foram crescidas em $5 \mathrm{ml}$ de meio 2 YT ON contendo $100 \mu \mathrm{g} / \mathrm{ml}$ por $16 \mathrm{~h}$ a $30{ }^{\circ} \mathrm{C}$ (pré-inóculo). Após $16 \mathrm{~h}$ de cultivo, o pré-inóculo foi centrifugado a $8.400 \mathrm{X}$ g por $5 \mathrm{~min}$. O precipitado bacteriano foi ressuspendido em $1 \mathrm{ml}$ de meio M9 (meio mínino) $\mathrm{ON}$ (sem $\mathrm{NaCl}$ ) e então adicionaram-se $500 \mu \mathrm{l}$ da supensão bacteriana para cada 1 litro de meio de cultura M9 sem sal, contendo 100 $\mu \mathrm{g} / \mathrm{ml}$, que foi cultivado a $30{ }^{\circ} \mathrm{C}$ sob agitação. Quando a $\mathrm{OD}_{600}$ atingiu 0,8 (aproximadamente 17 horas de crescimento), adiciononaram-se às culturas $100 \mathrm{mg} / \mathrm{ml}$ de lisina (Sigma), 100 $\mathrm{mg} / \mathrm{ml} \mathrm{de} \mathrm{fenilalanina} \mathrm{(Sigma),} 100 \mathrm{mg} / \mathrm{ml} \mathrm{de} \mathrm{treonina} \mathrm{(Sigma),} 50 \mathrm{mg} / \mathrm{ml} \mathrm{de} \mathrm{isoleucina}$ (Sigma), $50 \mathrm{mg} / \mathrm{ml}$ de valina (Sigma) e $60 \mathrm{mg} / \mathrm{ml}$ de selênio-metionina (Sigma). Após $15 \mathrm{~min}$ da adição dos aminoácidos, foi adicionado $300 \mathrm{mM}$ de $\mathrm{NaCl}$ na cultura de células. Procedeuse então a uma incubação de 3 horas a $30{ }^{\circ} \mathrm{C}$ sob agitação. Os passos subsequentes foram realizados de forma semelhante ao realizado no item 3.10.1.

\subsubsection{Expressão de HlyX e dos fragmentos N-terminal e intermediário de LipL32 em E.coli BL21(DE3) Star [plysS]}

Bactérias competentes E.coli BL21(DE3) Star [plysS] foram transformadas com as construções $h l y X / p A E$, N-terminal_lipL32/pAE ou intermediário_lipL32/pAE.

A transformação nas células competentes foi realizada de forma semelhante a da linhagem bacteriana DH5 $\alpha$, apenas com a exceção da forma pela qual as colônias foram selecionadas, pois a seleção neste caso deve ser baseada na resistência à ampicilina e ao cloranfenicol. A colônia escolhida foi inoculada em $50 \mathrm{ml}$ de meio líquido 2YT contendo 100 $\mu \mathrm{g} / \mathrm{ml}$ de ampicilina e $30 \mu \mathrm{g} / \mathrm{ml}$ cloranfenicol, incubada a $37{ }^{\circ} \mathrm{C}$ por 16 horas sob agitação. A cultura crescida por $16 \mathrm{~h}$ ( pré inóculo ) foi adicionada para 1 litro de cultura 2 YT e crescida a $37{ }^{\circ} \mathrm{C}$ sob agitação. Os passos subsequentes da expressão e tratamento final da cultura e precipitado bacteriano foram realizados de forma semelhante à realizada no item 3.10.1, com a única exceção de que o indutor adicionado quando a $\mathrm{OD}_{600}$ atingiu 0,6 foi 1,2 mM de IPTG.

O tratamento do precipitado bacteriano foi posteriormente tratado para a separação do sobrenadante, lavagem dos corpúsculos de inclusão com as soluções $1 \mathrm{M}$ e $8 \mathrm{M}$ uréia (lavagem e solubilização das proteínas insolúveis, respectivamente). As proteínas HlyX e o 
fragmento N-terminal de LipL32 foram expressas em sua maior parcela em forma de corpúsculos de inclusão (proteínas insolúveis). Já o fragmento intermediário de LipL32 foi encontrado na fração solúvel.

\subsection{Purificação das proteínas recombinantes}

\subsubsection{Purificação da proteína HlyX após renaturação protéica}

Os corpúsculos de inclusão, obtidos através do tratamento do precipitado bacteriano, foram lavados primeiramente com $20 \mathrm{ml}$ de uma solução contendo $50 \mathrm{mM}$ Tris- $\mathrm{HCl}, \mathrm{pH} 8,0$, 0,5 M NaCl, $5 \mathrm{mM} \beta$-mercaptoetanol e $1 \mathrm{M}$ uréia (solução $1 \mathrm{M}$ uréia). Os corpúsculos de inclusão foram solubilizados por 16 horas em $20 \mathrm{ml}$ de uma solução contendo $50 \mathrm{mM}$ Tris$\mathrm{HCl}, 0,5 \mathrm{M} \mathrm{NaCl}, 5 \mathrm{mM} \quad \beta$-mercaptoetanol, $8 \mathrm{M}$ uréia (solução $8 \mathrm{M}$ ). Para a renaturação protéica foi utilizada uma solução de 4 litros contendo $50 \mathrm{mM}$ de Tris-HCl $1 \mathrm{M}, \mathrm{pH}$ 8,0, 500 $\mathrm{mM} \mathrm{NaCl}$ e $5 \mathrm{mM}$ imidazol (solução de renaturação proteíca), onde foram gotejados os $20 \mathrm{ml}$ da solução $8 \mathrm{M}$ uréia, contendo os corpúsculos de inclusão solubilizados. Após o gotejamento da solução, os 4 litros de solução de renaturação ficaram durante $16 \mathrm{~h}$ a $18{ }^{\circ} \mathrm{C}$.

Para a purificação de HlyX foi utilizada a cromatografia de afinidade a metais bivalentes, pelo fato da proteína possuir uma cauda de seis histidinas adicionadas pelo vetor de expressão pAE, na sua porção N-terminal. A coluna $(1 \mathrm{~cm}$ de diâmetro) contendo $5 \mathrm{ml}$ da resina chelating sepharose (GE HealthCare ${ }^{\circledR}$ ) foi preparada com uma solução $300 \mathrm{mM} \mathrm{NiSO}_{4}$, lavada com $10 \mathrm{ml}$ de $\mathrm{H}_{2} \mathrm{O}$ para a remoção do excesso da solução de níquel e posteriormente equilibrada com o tampão de equilíbrio (solução de renaturação protéica). A solução foi então adsorvida pela coluna, com o auxílio da bomba peristáltica, com fluxo de 3,5 ml/min. Com o propósito de remover HlyX da coluna cromatográfica, esta foi lavada com incrementos na concentração de imidazol. Foram realizadas lavagens com soluções contendo 5, 20, 40 e 60 mM imidazol em 150 mM Tris-HCl, pH 8,0. Após as lavagens a proteína foi eluída da coluna com $25 \mathrm{ml}$ de uma solução contendo $1 \mathrm{M}$ imidazol em $150 \mathrm{mM}$ Tris-HCl, pH 8.0. A presença de proteína recombinante foi observada por SDS-PAGE $15 \%$.

As lavagens e frações eluídas nas quais encontrou-se proteína foram dialisadas em 2 litros de solução de 150 mM Tris-HCl, pH 8,0. As soluções de diálise foram renovadas a cada 24 horas, por 3 dias consecutivos, para que todo o imidazol fosse removido, e a solução de diálise equilibrada com a amostra. 
3.11.2 Purificação dos fragmentos de LipL32 e de LipL32 6xHis, através de cromatografia de afinidade a metais bivalentes

\section{Purificação do fragmento N-terminal de LipL32 em condições desnaturantes}

O tratamento do sedimento bacteriano da expressão do fragmento N-terminal de LipL32 foi realizado de forma similar ao item 3.11.1. Os $20 \mathrm{~mL}$ da solução $8 \mathrm{M}$ uréia contendo os corpúsculos de inclusão solubilizados foram adsorvidos pela coluna cromatográfica de dimensões e resina iguais ao item 3.11.1, previamente carregada com uma solução $300 \mathrm{mM} \mathrm{NiSO}_{4}$, e equilibrada com a solução de equilíbrio na qual o sedimentado bacteriano foi solubilizado, que neste caso foi a solução $8 \mathrm{M}$ uréia. Todo o volume da solução contendo os corpúsculos de inclusão solubilizados foi passado pela resina da coluna com o auxílio de uma bomba peristáltica, com fluxo de 1,0 $\mathrm{ml} / \mathrm{min}$. Com o propósito de remover proteínas contaminantes de E. coli da coluna, esta foi lavada com incrementos na concentração de imidazol. Foram realizadas lavagens com 10 volumes de soluções contendo 5, 20, 40 e $60 \mathrm{mM}$ imidazol, $8 \mathrm{M}$ uréia e $150 \mathrm{mM}$ Tris- $\mathrm{HCl} \mathrm{pH}$ 8,0. Após as lavagens foram utilizados $25 \mathrm{ml}$ de uma solução contendo $1 \mathrm{M}$ imidazol, $8 \mathrm{M}$ uréia e 150 Tris- $\mathrm{HCl} \mathrm{pH} 8,0$ para a eluição do fragmento $\mathrm{N}$-terminal. A presença de proteína recombinante foi observada por SDS-PAGE 18\%. As lavagens e frações eluídas nas quais encontrou-se proteína foram agrupadas e armazenadas a $4{ }^{\circ} \mathrm{C}$.

Purificação dos fragmentos intermediário e C-terminal da proteína LipL32 e

\section{LipL32 6xHis}

Os sobrenadantes obtidos através do tratamento dos sedimentados bacterianos das expressões dos fragmentos intermediário e C-terminal de LipL32 e de LipL32 6xHis foram adsorvidos pela mesma coluna cromatográfica do item anterior, previamente carregada com uma solução $300 \mathrm{mM} \mathrm{NiSO}$, e equilibrada com as soluções de equilíbrio na qual os sedimentados bacterianos foram homogeneizados, $150 \mathrm{mM}$ Tris- $\mathrm{HCl} \mathrm{pH} 8,0$. Todo o volume das soluções de sobrenadante $(100 \mathrm{ml})$ foi passado pela resina da coluna com o auxílio de uma bomba peristáltica, com fluxo de 1,0 ml/min. Com o mesmo objetivo de remover proteínas contaminantes de E. coli da coluna realizados na purificação da proteína HlyX e do fragmento N-terminal de LipL32, em cada purificação a coluna foi lavada com incrementos na concentração de imidazol. Foram realizadas lavagens com 10 volumes das soluções contendo 
5, 20, 40 e $60 \mathrm{mM}$ imidazol em $150 \mathrm{mM}$ Tris-HCl pH 8,0. Após as lavagens as proteína foram eluídas da coluna com $25 \mathrm{ml}$ de uma solução contendo $1 \mathrm{M}$ imidazol na mesma solução das lavagens. A presença das proteínas recombinantes foi observada por SDS-PAGE 18\% para os fragmentos de LipL32 e SDS-PAGE 15\% para LipL32 6xHis, devido à diferença das massas moleculares dos fragmentos e da proteína inteira. As lavagens e frações eluídas nas quais foram encontradas as proteínas foram dialisadas em 2 litros de solução de diálise $(150 \mathrm{mM}$ Tris- $\mathrm{HCl} \mathrm{pH}$ 8,0). As soluções de diálise foram renovadas a cada 24 horas, por 3 dias consecutivos, para que todo o imidazol fosse removido, e a solução de diálise equilibrada com a amostra. Após a diálise as proteínas purificadas foram armazenadas a $-20^{\circ} \mathrm{C}$.

\subsubsection{Purificação de LipL32 e LipL32 Se-M}

Para purificar as proteínas LipL32 e LipL32 Se-M, ambas sem a cauda de histidina, foram utilizadas as mesmas técnicas cromatográficas descritas abaixo.

\section{Cromatografia de troca iônica}

O sobrenadante do lisado bacteriano obtido na expressão foi adsorvido pela coluna (1 cm de diâmetro) cromatográfica de troca iônica preeenchida com $5 \mathrm{ml}$ da resina aniônica QSepharose (GE HealthCare ${ }^{\circledR}$ ), previamente equilibrada com uma solução $20 \mathrm{mM}$ trietanolamina, pH 7,8 (solução de equilíbrio) na qual o precipitado bacteriano foi homogeneizado. Todo o volume da solução de sobrenadante $(100 \mathrm{ml})$ foi passado pela coluna cromatográfica com o auxílio de uma bomba peristáltica, com fluxo de 1,0 ml/min. Após a passagem pela troca aniônica, a fração não adsorvida foi submetida a uma cromatografia catiônica SP-Sepharose (GE HealthCare ${ }^{\circledR}$ ), utilizando-se uma coluna de iguais dimensões e volume de resina e equilibrada com a mesma solução mencionada acima. Todo o volume da solução da fração não adsorvida pela cromatografia aniônica $(100 \mathrm{ml})$ foi passado pela resina da coluna com o auxílio de uma bomba peristáltica, com fluxo de 1,0 ml/min. Para remover LipL32 da coluna, esta foi submetida a um gradiente crescente e descontínuo de $\mathrm{NaCl}$. Foram realizadas lavagens com soluções contendo $0,1,0,3,0,5,0,7,1,0,1,5$ e 2,0 $\mathrm{M} \mathrm{NaCl}$ em solução $20 \mathrm{mM}$ trietanolamina, $\mathrm{pH}$ 7,8. A presença de proteína recombinante foi observada por SDS-PAGE $15 \%$ e as alíquotas nas quais foram encontradas menos contaminantes foram separadas para outra etapa cromatográfica. 


\section{Cromatografia hidrofóbica}

A cromatografia hidrofóbica foi utilizada para que os demais contaminantes remanescentes da purificação catiônica fossem eliminados da preparação. As amostras mais purificadas foram reunidas e $\mathrm{NaCl}$ foi adicionado já que a cromatografia hidrofóbica baseia-se no efeito "salting-out". As amostras passaram a ter uma concentração de $3 \mathrm{M} \mathrm{NaCl}$ para que LipL32 fosse adsorvida pela resina Phenyl-Sepharose (GE HealthCare ${ }^{\circledR}$ ). A coluna cromatográfica de $1 \mathrm{~cm}$ de diâmetro, contendo $5 \mathrm{ml}$ da resima Phenyl sepharose, foi previamente equilibrada com uma solução $3 \mathrm{M} \mathrm{NaCl}, 20 \mathrm{mM}$ trietanolamina, $\mathrm{pH}$ 7,8. Todo o volume da amostra foi passado pela resina da coluna com o auxílio de uma bomba peristáltica, com fluxo de 1,0 ml/min. A remoção de LipL32 da coluna, foi realizada utilizando-se um gradiente decrescente e descontínuo de $\mathrm{NaCl}$. Foram realizadas coletas com soluções contendo 2,5, 2,0, 1,5, 1,0, 0,7, 0,5, 0,3, 0,1 M NaCl em solução $20 \mathrm{mM}$ trietanolamina, $\mathrm{pH} 7,8$. Foram também realizadas coletas com $20 \mathrm{mM}$ trietanolamina, $\mathrm{pH}$ 7,8 e $\mathrm{H}_{2} \mathrm{O}$. A presença de proteína recombinante foi observada por SDS-PAGE 15\%. As amostras eluídas nas quais encontrou-se a proteína purificada foram dialisadas em 2 litros de solução de diálise (20 mM trietanolamina, pH 7,8). As soluções de diálise foram renovadas a cada 24 horas, por 3 dias consecutivos, para que todo o $\mathrm{NaCl}$ fosse removido, e a solução de diálise equilibrada com a amostra. Após a diálise as amostras foram armazenadas a $4{ }^{\circ} \mathrm{C}$.

\subsection{Eletroforese em gel de poliacrilamida com dodecil sulfato de sódio (SDS-PAGE)}

As eletroforeses foram realizadas de acordo com protocolos previamente descritos (Laemmli, 1970; Sambrook, et al., 1989). Os géis de poliacrilamida utilizados possuíam 5\% de bisacrilamida/acrilamida no gel de empilhamento e $15 \%$ ou $18 \%$ no gel de resolução para LipL32 e HlyX ou fragmentos N-terminal, intermediário e C-terminal de LipL32, respectivamente, preparados a partir de uma solução de acrilamida $29 \%$ (m/V) e bisacrilamida $1 \%(\mathrm{~m} / \mathrm{V})$. As eletroforeses foram realizadas a $25 \mathrm{~mA}$ por gel em tampão trisglicina 1X. Os géis de resolução foram corados com solução corante, por $16 \mathrm{~h}$ a temperatura ambiente, descorados com solução descorante, incubados com solução secante, e envolvidos em papel celofane para secagem. 


\subsection{Dicroísmo Circular}

A caracterização da estrutura secundária das proteínas HlyX, LipL32 6xHis e LipL32 foi realizada através de dicroísmo circular, utilizado-se o espectropolarímetro modelo J-810 (Jasco Inc.) conectado ao sistema Peltier Jasco PFD-425S para o controle de temperatura. Foram mensurados comprimentos de onda de 190 a 260 nm, utilizando-se célula de quartzo com $1 \mathrm{~mm}$ de caminho óptico, por nove vezes consecutivas, a temperatura de $20^{\circ} \mathrm{C}$, em intervalo de $0,5 \mathrm{em} 0,5 \mathrm{~nm}$, e velocidade de $50 \mathrm{~nm} / \mathrm{min}^{3}$

Para o ensaio a proteína HlyX encontrava-se na concentração de $10 \mu \mathrm{M}$ em $10 \mathrm{mM}$ tampão fosfato, pH 7,4 e as proteínas LipL32 6xHis e LipL32 em uma concentração $10 \mu \mathrm{M}$ em 10 mM TrisHCl, pH 8,0. A concentração de proteínas foi estimada através de leitura óptica de $280 \mathrm{~nm}$, considerando-se os coeficientes de extinção molar de LipL32 6xHis (34990 $\left.\mathrm{M}^{-1} \mathrm{~cm}^{-1}\right)$, LipL32 (27681 $\left.\mathrm{M}^{-1} \mathrm{~cm}^{-1}\right)$ e HlyX $\left(46510 \mathrm{M}^{-1} \mathrm{~cm}^{-1}\right)$, baseados na seqüência de aminoácidos da proteína recombinante esperada ou também através de comparação densitométrica com uma curva de BSA (Bovine Serum Albumin) em SDS-PAGE.

\subsection{Ensaios de Western blot}

Para os ensaios de immunoblotting foi necessária a geração de anticorpos contra as proteínas purificadas, a produção de extratos de diferentes cepas de Leptospira e a obtenção de soros de pacientes ${ }^{(4)}$ com leptospirose confirmada.

\subsubsection{Produção de anticorpos gerados contra as proteínas purificadas}

Seis grupos de camundongos, cada grupo contendo 10 animais, Balb/C fêmeas de 5 a 8 semanas foram imunizados intraperitonealmente com $10 \mu \mathrm{g}$ de HlyX, LipL32 6xHis, fragmento $\mathrm{N}$-terminal, intermediário e C-terminal ou LipL32 e incorporadas em $\mathrm{Al}(\mathrm{OH})_{3}$. As imunizações foram realizadas em um período de 4 semanas, com reforço de doses toda a semana. Os camundongos foram sangrados pelo plexo retrorbital, uma vez a cada semana e o sangue foi incubado por $30 \mathrm{~min}$ a $37^{\circ} \mathrm{C}$. Logo em seguida, o sangue foi acondicionado por 30

(3) O espectropolarímetro, pertencente ao Laboratório de Biofísica Molecular, Departamento de Química, FFCLRP-USP, Ribeirão Preto, sob responsabilidade do Prof. Dr. Richard John Ward foi gentilmente emprestado para que fossem realizadas as análises de estrutura secundária.

(4) Os soros de pacientes com leptospirose fazem parte da coleção de soros sob responsabilidade da Dra Eliete Caló Romero, do Instituto Adolfo Lutz 
min a $4{ }^{\circ} \mathrm{C}$ para a retenção do coágulo. Em seguida, o coágulo foi removido, procedeu-se à centrifugação, o soro foi coletado do sobrenadante e armazenado a $-20{ }^{\circ} \mathrm{C}$.

\subsubsection{Ensaio imunoenzimático (ELISA)}

Foram utilizadas placas de microtítulo (Maxisorp-NUNC ${ }^{\circledR}$ ) cujos poços foram revestidos com $1 \mu \mathrm{g} / \mathrm{mL}$ de cada proteína purificada em $0,05 \mathrm{M}$ de tampão carbonatobicarbonato, $\mathrm{pH} 9,6$ a $4{ }^{\circ} \mathrm{C}$. As placas foram lavadas três vezes com 0,05\% Tween 20/ Tampão fosfato salina, pH 7,4 (PBS-T). Foram adicionados $100 \mu$ de tampão de bloqueio (10\% leite desnatado Molico ${ }^{\circledR}$ em PBS-T), e a placa foi incubada a $37{ }^{\circ} \mathrm{C}$ durante $1 \mathrm{~h}$. Após a remoção do tampão de bloqueio com três lavagens de PBS-T, diluições dos soros contendo anticorpos gerados em camundongos contra as proteínas purificadas, em $1 \%$ de albumina de soro bovino (BSA) e tampão PBS-T foram adicionados à placa contendo a proteína correspondente ao soro. As placas foram incubadas a $37{ }^{\circ} \mathrm{C}$ por $1 \mathrm{~h}$. Após as lavagens, diluições apropriadas de anti-IgG de camundongo gerada em cabra conjugada a peroxidase (Sigma) foram adicionadas às placas e incubadas durante $1 \mathrm{~h}$ a $37{ }^{\circ} \mathrm{C}$. As placas foram reveladas pela adição de $100 \mu \mathrm{l}$ de uma solução contendo 8 mg de OPD em $20 \mathrm{ml}$ de tampão citrato-fosfato $0,2 \mathrm{M}, \mathrm{pH} 5,0$ na presença de $10 \mu \mathrm{l}$ of $\mathrm{H}_{2} \mathrm{O}_{2}$. A reação foi interrompida pela adição de $50 \mu \mathrm{l}$ de $4 \mathrm{M} \mathrm{H}_{2} \mathrm{SO}_{4}$, e absorbância foi mensurada em comprimento de onda de 492 nm.

\subsubsection{Western blot}

As proteínas recombinantes e extratos de Leptospira (descritos no item 3.4) foram fracionados em SDS-PAGE $15 \%$ e $18 \%$ e eletrotransferidos a $350 \mathrm{~mA}$ para membranas de nitrocelulose em solução tampão de transferência, através de sistema de transferência úmida Biorad (Biorad Biosystems). As membranas foram incubadas com $10 \%(\mathrm{~m} / \mathrm{V})$ de leite desnatado Molico $^{\circledR}$ em PBS-T, e após três lavagens de 10 min com PBS-T, elas foram incubadas com diluições adequadas de anticorpos policlonais anti-HlyX, anti-LipL32 6xHis, anti-N-terminal, anti-intermediário, anti-C-terminal e anti-LipL32, produzidos em camundongos, em leite desnatado Molico ${ }^{\circledR}$-PBS-T 5\% por $1 \mathrm{~h} 30 \mathrm{~min}$.

Seguindo uma repetição de lavagens com PBS-T como descrito acima, as membranas foram incubadas com diluições apropriadas de anti-IgG de camundongo gerada em cabra 
conjugada a peroxidase (Sigma) em 5\% leite desnatado Molico ${ }^{\circledR}$-PBS-T por 1 h, lavadas e reveladas com reagente ECL (GE Healthcare). Alternativamente, $2 \mu \mathrm{g}$ de HlyX, LipL32 $6 \mathrm{xHis}$ e seus fragmentos foram fracionadas em $15 \%$ e $18 \%$ SDS-PAGE, transferidos e incubados com soros de pacientes diagnosticados com leptospirose (fase aguda e fase covalescente). Para estes blots foram utilizados anticorpos anti-IgM (cadeia $\mu$-específico) e anti-IgG (cadeia $\delta$-específico) de humanos gerados em cabra conjugados a peroxidase (Sigma).

\subsection{Ensaio de ligação das proteínas LipL32 6xHis e HlyX a componentes de matriz extracelular}

Os ensaios de ligação foram realizados segundo um protocolo já descrito (Cameron, 2003), com algumas modificações. Placas de ELISA com superfícies altamente aderentes (Nunc-Immuno Plate MaxiSorp Surface) foram revestidas com $1 \mu \mathrm{g}$ de laminina, colágeno Tipo I, colágeno Tipo IV, fibronectina celular, fibronectina plasmática, e fetuína (controle negativo, proteína glicosilada) diluídos em $100 \mu \mathrm{l}$ de PBS. As placas foram mantidas a $37^{\circ} \mathrm{C}$ por $2 \mathrm{~h}$. Os poços foram lavados três vezes com PBS-0,05\% Tween 20 (PBST). O bloqueio foi feito com $200 \mu \mathrm{l}$ de BSA $1 \%$ por 1 h a $37^{\circ} \mathrm{C}$, seguido de uma incubação a $4{ }^{\circ} \mathrm{C}$ por toda a noite.

Um micrograma de proteína recombinante diluída em PBS foi adicionado a cada poço. Após um período de incubação de $1 \mathrm{~h} 30 \mathrm{~min}$ a $37^{\circ} \mathrm{C}$, os poços foram lavados seis vezes com PBST. As proteínas aderidas foram detectadas pela adição de anti-soros correspondentes produzidos em camundongos em diluições 1:10.000 seguida de uma incubação com anticorpo anti-IgG de camundongo conjugado a peroxidase (1:5.000). Após três lavagens com PBST, foi adicionado OPD (0,04\%) diluído em tampão citrato-fosfato ( $\mathrm{pH} 5,0)$ e $0,01 \%$ de $\mathrm{H}_{2} \mathrm{O}_{2}$. Após 15 min, a reação foi interrompida pela adição de $50 \mu 1$ de $\mathrm{H}_{2} \mathrm{SO}_{4} 8 \mathrm{M}$. A absorbância a $492 \mathrm{~nm}$ foi determinada em um leitor de microplacas (Labsystems Uniscience, Multiskan $\mathrm{EX})$.

Para as análises estatísticas, a ligação de HlyX e LipL32 aos componentes de matriz extracelular foi comparada às suas ligações com fetuína (controle negativo) através do teste $t$ de Student. Nos experimentos de dose-dependência, LipL32 6xHis e os fragmentos intermediário e C-terminal foram adicionados em concentrações variando-se de 0 a $4 \mu \mathrm{M}$ em 
$100 \mu 1$ de PBS em poços revestidos com fibronectina plasmática, seus fragmentos ligantes de heparina (F30) e gelatina (F45) e colágeno tipo IV.

Para os experimentos de dose-dependência de ligação de HlyX a fibronectina plasmática, F30 e colágeno tipo IV, as concentrações variam de 0 a $2 \mu \mathrm{M}$. Ensaios de competição envolvendo F30, F45 e colágeno tipo IV foram realizados variando-se a concentração dos fragmentos C-terminal e intermediário de 0 a $7 \mu \mathrm{M}$ na presença de $1,5 \mu \mathrm{M}$ de LipL32 6xHis. Para avaliar se moléculas de heparina (Liquemine, Roche ${ }^{\circledR}$ ) e de gelatina (Sigma) poderiam competir pelos domínios de ligação da fibronectina plasmática, F30 e F45, respectivamente, com LipL32 6xHis e o fragmento C-terminal, incubou-se $2 \mu \mathrm{M}$ de proteína recombinante na presença de heparina ( 0 a 500 UI) ou gelatina ( 0 a $50 \mu \mathrm{g})$. A competição entre HlyX e heparina pela ligação ao domínio F30 também foi realizada com uma concentração fixa de $2 \mu \mathrm{M}$ de HlyX na presença de concentrações crescentes de heparina ( 0 a 500 UI). A detecção das proteínas aderidas foi realizada como descrito anteriormente, no ensaio de ligação das proteínas recombinantes aos componentes de matriz extracelular.

\subsection{Ensaios de imunização e desafio animal}

\subsubsection{Ensaios de imunização ativa com as proteínas LipL32 e/ou HlyX e desafio homólogo em hamster}

Hamsters (Mesocricetus auratus) recém-desmamados fêmeas pesando entre 80 a $120 \mathrm{~g}$ foram divididos em 5 grupos de 10 animais. Os grupos foram imunizados duas vezes em intervalos de 2 semanas com injeções subcutâneas de $50 \mu \mathrm{g}$ de LipL32 recombinante, $50 \mu \mathrm{g}$ de HlyX recombinante, uma combinação de HlyX e LipL32 (50 $\mu$ g de cada), $50 \mu \mathrm{g}$ do fragmento C-terminal de LigA (resíduos de aa 817-1224 aa), bacterina (108 células/dose) ou salina, usando nas preparações hidróxido de alumínio como adjuvante (para cada $1 \mu \mathrm{g}$ de proteína recombinante, $10 \mu \mathrm{g} \mathrm{Al}^{+3}$ ). A preparação da bacterina foi realizada de acordo com o protocolo descrito por Silva e colaboradores (2007). Para a obtenção de soro, o sangue foi coletado do plexo retrorbital dos animais nos dias 0 (pré-imune) e 30.

Os animais vacinados foram desafiados intraperitonealmente com aproximadamente $10^{5}$ leptospiras (L. interrogans sorovar Copenhageni, linhagem ATCC BAA-1198). O número de leptospiras injetadas nos hamsters vacinados para o desafio animal foi estimado a partir do cálculo da $\mathrm{LD}_{50}$ (aproximadamente 170 leptospiras). Para o cáculo foram preparados inóculos 
contendo diluições do macerado do fígado dos hamsters infectados necropsiados cultivados em meio EMJH enriquecido em uma temperatura de $28^{\circ} \mathrm{C}$. Após cultivo de 2 semanas, os inóculos contendo as diferentes diluições foram injetados em grupos de animais sadios para verificação da diluição mínima capaz de levar ao óbito $50 \%$ dos animais infectados $\left(\mathrm{DL}_{50}\right)$. O cálculo da $\mathrm{LD}_{50}$ foi baseado no método de Reed-Muench (Reed e Muench, 1938).

Após o desafio a sobrevivência foi monitorada e animais que sobreviveram até o dia 58 foram sacrificados e tiveram seus fígados coletados para análise quanto à presença de leptospiras, através do cultivo do macerado do fígado cultivado em meio EMJH enriquecido a $28^{\circ} \mathrm{C}$.

\subsubsection{Determinação dos títulos de anticorpos IgG gerados contra LipL32 e HlyX}

Foram utilizadas placas de microdiluição (Maxisorp-NUNC) que foram incubadas a 4 ${ }^{\circ} \mathrm{C}$ com $1 \mu \mathrm{g} /$ poço de LipL32, HlyX e fragamento C-terminal de LigA purificadas em 0,05 M de tampão carbonato-bicarbonato, $\mathrm{pH}$ 9,6. As placas foram lavadas três vezes com 0,05\% Tween 20/Tampão fosfato salina, pH 7,4 (PBS-T). Adicionou-se $100 \mu \mathrm{l}$ de tampão de bloqueio ( $10 \%$ leite desidratado sem gordura em PBS-T), e as placas foram incubadas a $37{ }^{\circ} \mathrm{C}$ durante 1h. Após a remoção do tampão de bloqueio com três lavagens de PBS-T, diluições de soros coletados dos animais imunizados como descrito no item anterior, em 1\% BSA e tampão PBS-T, foram adicionadas às placas que foram incubadas a $37{ }^{\circ} \mathrm{C}$ por $1 \mathrm{~h}$. Após as lavagens, diluições apropriadas de anticorpo monoclonal anti-IgG de Hamster gerado em cabra conjugada a peroxidase (Sigma) ou anticorpo policlonal anti-IgG de Hamster gerado em coelho (Sigma) foram adicionadas nas placas e incubadas durante $1 \mathrm{~h}$ a $37^{\circ} \mathrm{C}$.

Nas placas onde adicionou-se anticorpo policlonal anti-IgG de Hamster gerado em coelho, foi realizada uma etapa adicional de incubação com diluição apropriada de anticorpo anti-IgG de coelho conjugado a peroxidase (Sigma) durante $1 \mathrm{~h}$ a $37^{\circ} \mathrm{C}$. As placas foram reveladas pela adição de $100 \mu \mathrm{l}$ de uma solução contendo 8 mg de OPD em $20 \mathrm{ml}$ de tampão citrato-fosfato $0,2 \mathrm{M}, \mathrm{pH} 5,0$ na presença de $10 \mu \mathrm{l}$ of $\mathrm{H}_{2} \mathrm{O}_{2}$. A reação foi interrompida pela adição de $50 \mu \mathrm{l}$ de $4 \mathrm{M} \mathrm{H}_{2} \mathrm{SO}_{4}$, e a absorbância foi mensurada em comprimento de onda de $492 \mathrm{~nm}$. A análise estatística da produção de anticorpos nos animais foi feita pelo teste de Mann-Whitney. 


\subsection{Amplificação dos genes $h l y \mathrm{X}$, lipL32 e dos fragmentos correspondentes ao N- terminal, intermediário e C-terminal de LipL32}

Os genes hlyX e lipL32 foram amplificados por PCR a partir do DNA genômico de $L$. interrogans sorovar Copenhageni, linhagem L1-130 da Fiocruz-Bahia (Ko, et al., 1999; Nascimento, et al., 2003). Nas figuras 11A e 11B podem ser verificados os produtos das PCRs de aproximadamente 1,1 Kpb para hlyX e 759 pb para lipL32, respectivamente. Os fragmentos de lip $\mathrm{L} 32$ correspondentes ao N-terminal, intermediário e C-terminal da proteína foram amplificados por PCR a partir do vetor de subclonagem pGEM-T easy contendo lipL32. Na figura 11B podem ser observados os produtos das amplificações dos fragmentos $\mathrm{N}$-terminal, intermediário e C-terminal que correspondem a 222 pb, 288 pb e 276 pb, respectivamente. E. coli $\mathrm{DH} 5 \alpha$ quimicompetentes foram transformadas com as construções obtidas nas subclonagens ( $h l y \mathrm{X} / \mathrm{pCR}^{\mathrm{R}} 4 \mathrm{Blunt}-\mathrm{TOPO}$ e lip $\mathrm{L} 32$ ou fragmentos N-terminal, intermediário e C-terminal/pGEM-T), e as bactérias recombinantes, resistentes à ampicilina, foram selecionadas para a extração plasmidial. Os genes hlyX, lipL32 e fragmentos de lipL32 foram sequenciados e tiveram a sequência confirmada. Todas as construções obtidas nas subclonagens foram devidamente digeridas e os genes de interesse liberados e ligados no vetor de expressão em E. coli, pAE.

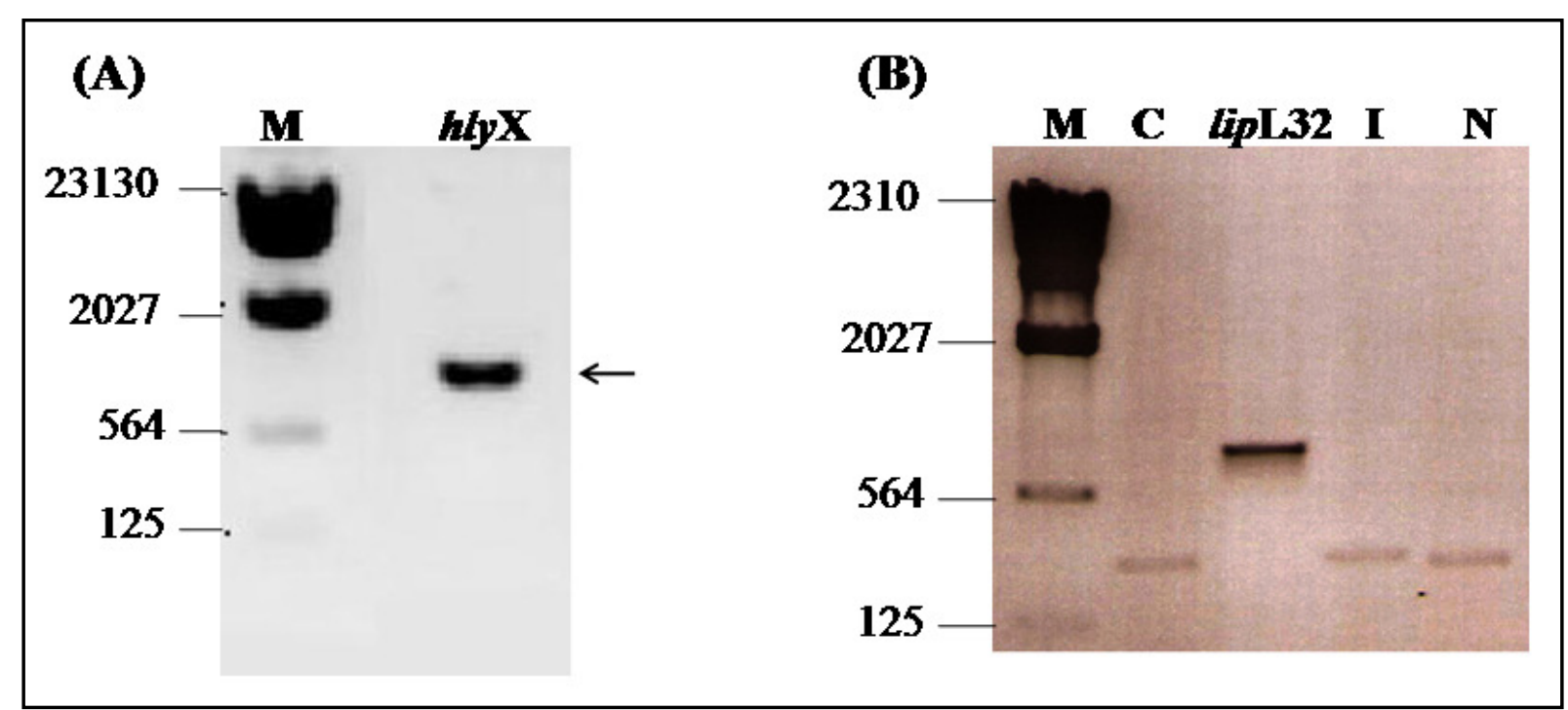

Figura 11 - Amplificação dos genes hlyX (A) de 1,1 kb e lipL32 (B) de 759 pb. Em B, pode-se verificar as amplificações dos fragmentos de lipL32, correspondente ao $\mathrm{N}$-terminal $(\mathrm{N})$ de 222 pb, intermediário (I) de 288 pb e C-terminal (C) de 276 pb. 


\subsection{Expressão das proteínas recombinantes}

As expressões das proteínas recombinantes de interesse foram testadas nas cepas $E$. coli BL21 (SI) cultivada em meio 2YT ON-amp a $30{ }^{\circ} \mathrm{C}$ ou E. coli BL21 (DE3) star [plysS] cultivada em meio 2 YT-amp/clo a $37^{\circ} \mathrm{C}$. Os resultados obtidos utilizando-se as duas cepas de expressão mostraram que a proteína HlyX mostrou ser expressa somente na cepa E. coli BL21 (DE3) star [plysS] em maiores níveis na forma insolúvel. A cepa de expressão E. coli BL21 (DE3) star [plysS] tranformada com a construção hlyX_pAE não foi capaz de formar unidades formadoras de colônias (UFCs).

As proteínas LipL32 6xHis, LipL32 e LipL32 Se-M foram expressas em ambas as cepas testadas predominantemente na forma solúvel (sobrenadante) e em quantidades semelhantes entre si. Com relação a análise das expressões dos fragmentos de LipL32, Nterminal, intermediário e $\mathrm{C}$-terminal foi possível verificar que o tanto o fragmento $\mathrm{N}$-terminal como o intermediário foram expressos em maiores quantidades na cepa E. coli BL21 (DE3) star [plysS], diferentemente do fragmento C-terminal que obteve melhores níveis de expressão com a cepa E. coli BL21 (SI) (dados comparativos não mostrados). Quanto a forma de expressão, solúvel ou insolúvel, ambos os fragmentos intermediário e C-terminal foram expressos na forma solúvel, diferentemente do fragmento $\mathrm{N}$-terminal que obteve sua maior expressão em forma de corpúsculos de inclusão.

As expressões das proteínas recombinantes podem ser visualizadas nos géis SDSPAGE juntamente com as respectivas purificações, no item 4.3.

As massas moleculares e os pontos isoelétricos (pIs) teóricos das proteínas recombinantes expressas foram calculados, através da sequência de aminoácidos de cada proteína, em programa disponível no site: http://www.expasy.ch. Os valores obtidos estão na tabela 2. 
$\underline{\text { Tabela } 2 \text { - Massas moleculares e pontos isoelétricos (pIs) das proteínas recombinates }}$

\begin{tabular}{ccccc} 
Proteínas & $\begin{array}{c}\text { Massas } \\
\text { moleculares } \\
\text { (kDa) }\end{array}$ & $\begin{array}{c}\text { Pontos } \\
\text { Isoelétricos }\end{array}$ & $\begin{array}{c}\mathbf{N}^{\circ} \text { de } \\
\text { aminoácidos }\end{array}$ & $\begin{array}{c}\text { Sequências } \\
\text { correspondentes }\end{array}$ \\
\hline HlyX & 42,3 & 6,31 & 366 & $22-378$ aa \\
LipL32 6xHis & 30,7 & 6,84 & 280 & $21-272$ aa \\
LipL32 & 27,6 & 5,81 & 252 & $21-272$ aa \\
N-terminal & 8,78 & 6,96 & 80 & $21-92$ aa \\
Intermediário & 11,69 & 5,45 & 102 & $93-184$ aa \\
C-terminal & 10,7 & 9,29 & 97 & $185-272$ aa \\
\hline
\end{tabular}

4.3 Purificação das proteínas recombinantes através de cromatografia de afinidade a metais bivalentes ou cromatografia de troca iônica e hidrofóbica

\subsubsection{Purificação das proteínas expressas na forma solúvel, LipL32 6xHis e os fragmento intermediário e C-terminal de LipL32}

As purificações das proteínas LipL32 6xHis e dos fragmentos intermediário e Cterminal foram realizadas dos sobrenadantes de culturas induzidas, através de cromatografia de afinidade. Nos géis de SDS-PAGE $15 \%$ e $18 \%$ respectivamente, foram observadas bandas com massas moleculares de aproximadamente 30,7 kDa (Figura 12), 11,7 kDa (Figura 13) e $10,7 \mathrm{kDa}$ (Figura 14) correspondentes às proteínas LipL32 6xHis e os fragmentos intermediário e C-terminal purificados, respectivamente.

LipL32 6xHis foi encontrada tanto na lavagem $60 \mathrm{mM}$ imidazol (Figura 12A) como nas frações de $1 \mathrm{M}$ imidazol (Figura 12B), porém nas frações eluídas onde a proteína estava mais concentrada, foi verificada a presença de contaminantes de E. coli. Sendo assim, somente a lavagem $60 \mathrm{mM}$ imidazol e as frações eluídas, 1 a 4 com $1 \mathrm{M}$ imidazol, contendo LipL32 em melhores condições de pureza, foram reunidas para uso posterior.

O fragmento intermediário de LipL32 foi eluído na lavagem $40 \mathrm{mM}$ imidazol (Figura 13A) e nas eluições $1 \mathrm{M}$ imidazol (Figura 13B). Somente a lavagem $40 \mathrm{mM}$ imidazol foi utilizada, devido a presença de muitos contaminantes em praticamente todas as eluições realizadas com $1 \mathrm{M}$ imidazol. 
A eluição do fragmento C-terminal de LipL32 ocorreu na lavagem $60 \mathrm{mM}$ imidazol e nas eluições com $1 \mathrm{M}$ imidazol onde houve intensa contaminação de proteínas de E. coli e as maiores quantidades de eluição deste fragmento (Figura 14). Desta forma, somente a lavagem $60 \mathrm{mM}$ imidazol e as frações 1 a 6 na concentração $1 \mathrm{M}$ imidazol foram selecionadas para serem reunidas e processadas.

Todas as purificações de LipL32 6xHis e dos fragmentos intermediário e C-terminal foram armazenadas a $-20^{\circ} \mathrm{C}$.

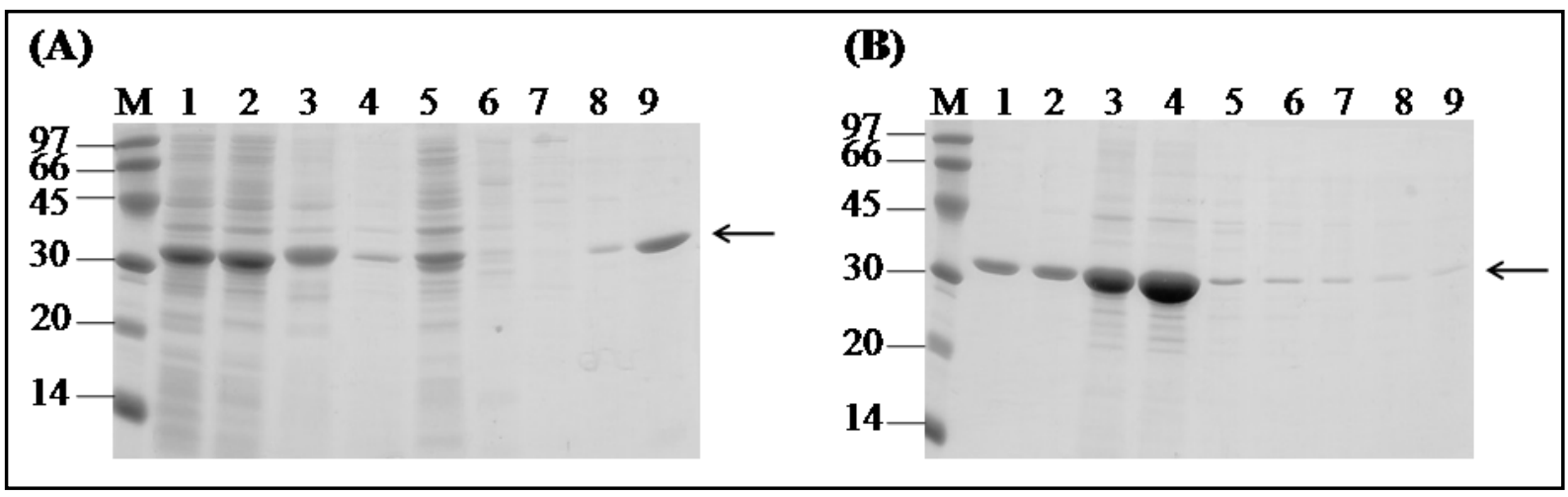

Figura 12 - SDS-PAGE 15\% da purificação de LipL32 6xHis a partir da fração solúvel de extratos de E. coli recombinante induzida. (A) $\mathrm{M}$ se refere ao padrão de massa molecular, poço 1 se refere ao extrato de E. coli BL21 (SI) induzida, 2 ao sobrenadante, 3 ao corpúsculo de inclusão solubilizado em solução $8 \mathrm{M}$ uréia, 4 a lavagem do corpúsculo de inclusão em solução $1 \mathrm{M}$ uréia, 5 é a fração não adsorvida à coluna de $\mathrm{Ni}^{2+}$ sepharose, 6 a 9 às lavagens com 5, 20, 40 e $60 \mathrm{mM}$ imidazol, respectivamente. (B) M é o padrão de massa molecular, 1 a 9 referem-se às frações ímpares 1-17 eluídas da coluna de $\mathrm{Ni}^{2+}$ sepharose. A banda correspondente a LipL32 6xHis (30,7 kDa) está indicada pela seta.

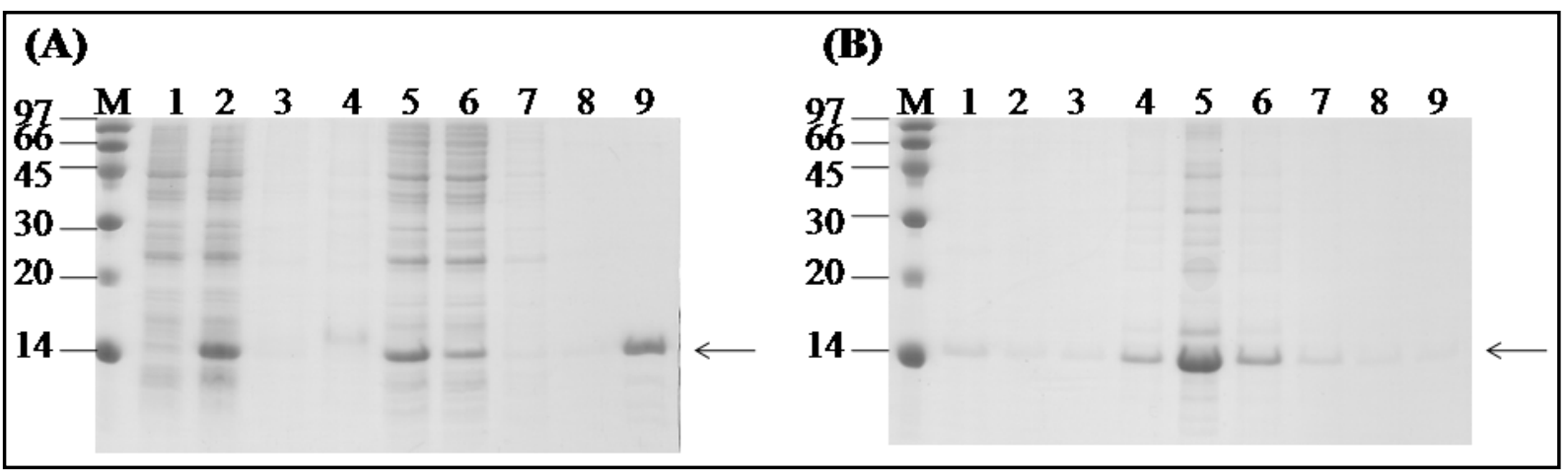

Figura 13 - SDS-PAGE 18\% da purificação do fragmento intermediário de LipL32 a partir da fração solúvel de extratos de E. coli induzida. (A) refere-se ao marcador de massa molecular, 1 ao extrato de $E$. coli recombinante não induzida, 2 ao extrato de $E$. coli recombinante induzida, 3 à lavagem dos corpúsculos de inclusão com solução $1 \mathrm{M}$ uréia, 4 aos corpúsculos de inclusão solubilizados em solução $8 \mathrm{M}$ uréia, 5 ao sobrenadante, 6 a fração não adsorvida na coluna, 7-9 referem-se às lavagens com 5, 20 e $40 \mathrm{mM}$, respectivamente. (B) M indica o marcador de massa molecular, 1 a lavagem $60 \mathrm{mM}$ imidazol, 2-9 referemse às frações ímpares 1-15 eluídas da coluna $\mathrm{Ni}^{2+}$ sepharose com $1 \mathrm{M}$ imidazol. A banda referente ao fragmento intermediário $(11,7 \mathrm{kDa})$ está indicada pela seta. 


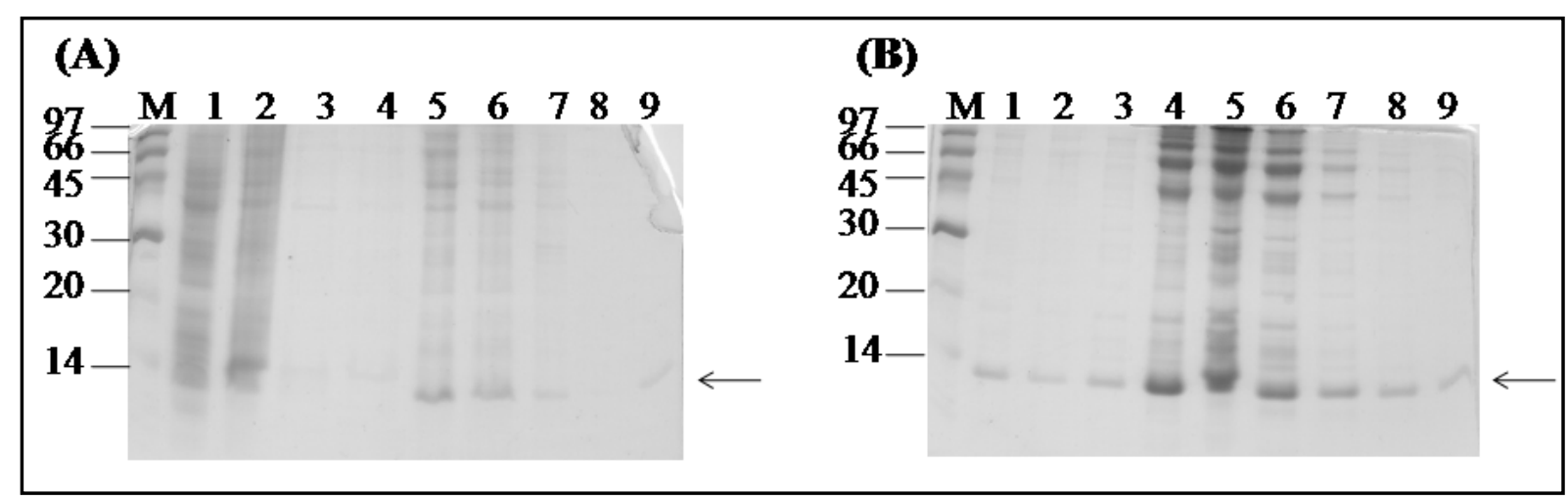

Figura 14 - SDS-PAGE $18 \%$ da purificação do fragmento C-terminal de LipL32 a partir da fração solúvel de extratos de E. coli recombinante induzida. (A) M indica o marcador de massa molecular, poço 1 refere-se ao extrato de $E$. coli recombinante não induzida, 2 ao extrato de $E$. coli induzida, 3 à lavagem do corpúsculo de inclusão com solução $1 \mathrm{M}$ uréia, 4 à solubilização dos corpúsculos de inclusão com solução $8 \mathrm{M}$ uréia, 5 à fração solúvel, 6 à fração não adsorvida, 7-9 referem-se às lavagens com 5, 20 e $40 \mathrm{mM}$, respectivamente. (B) $\mathrm{M}$ refere-se ao marcador de massa molecular, 1 à lavagem $60 \mathrm{mM}$ imidazol, 2-9 indicam às frações ímpares 1 a 15 eluídas da coluna $\mathrm{Ni}^{2+}$ sepharose, com $1 \mathrm{M}$ imidazol. A banda correspondente ao fragmento C-terminal de LipL32 (10,7 kDa) está indicada pela seta.

\subsubsection{Purificação das proteínas expressas em corpúsculos de inclusão, HlyX e o fragmento}

\section{N-terminal de LipL32}

A proteína HlyX e o fragmento N-terminal de LipL32 foram purificados a partir da expressão destas proteínas na fração insolúvel solubilizadas em solução $8 \mathrm{M}$ uréia.

Previamente ao processo de purificação da proteína HlyX esta foi renaturada conforme o item 3.11.1. Na figura 15, pode-se verificar que a maior fração de HlyX (42,3 kDa) foi eluída nas lavagens 40 e 60 mM imidazol. Houve também eluição de HlyX nas frações eluídas com $1 \mathrm{M}$ imidazol, mas em pouca quantidade e impura. Após a diálise das lavagens contendo HlyX foi necessária a adição de 1 mM PMSF, para impedir a ação de proteases. 


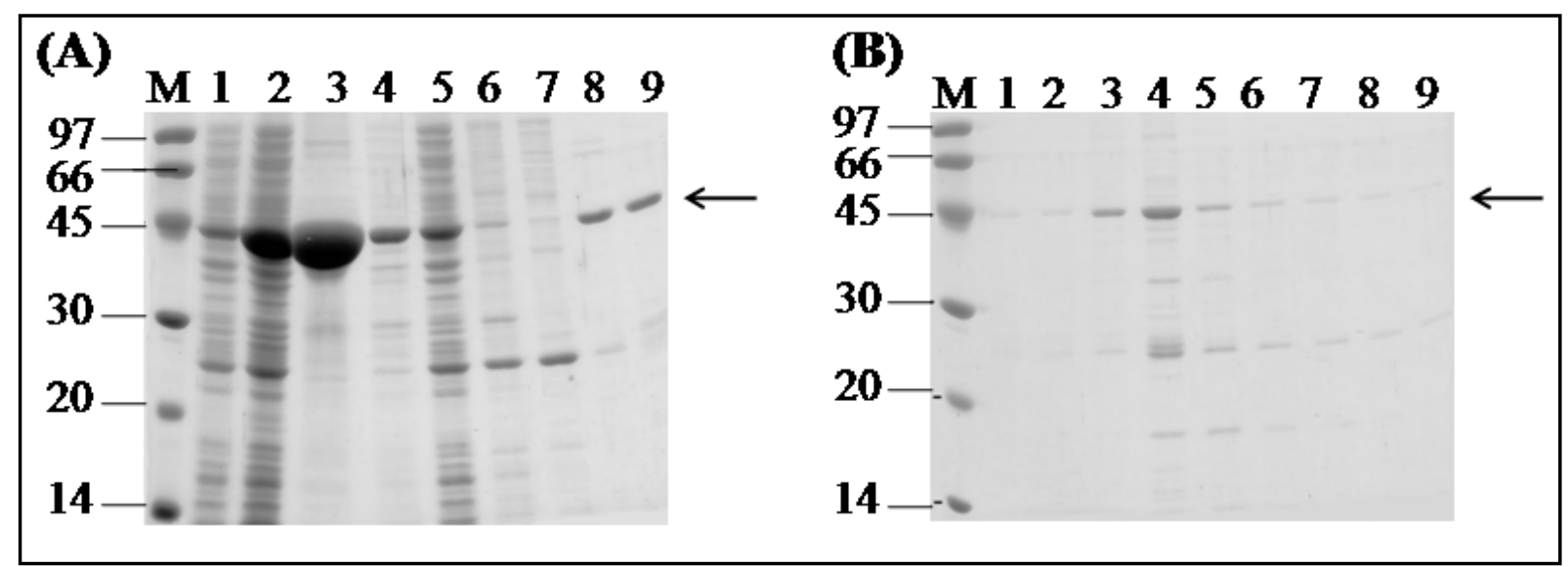

Figura 15 - SDS-PAGE 15\% da purificação de HlyX renaturada, a partir do corpúsculo de inclusão obtidos de extratos de E. coli recombinante induzida. (A) M indica o marcador de massa molecular, poço 1 refere-se ao extrato de E. coli recombinante não induzido, 2 ao extrato de $E$. coli recombinante induzido, 3 ao corpúsculo de inclusão solubilizado em solução 8 M uréia, 4 a lavagem do corpúsculo de inclusão em 1 M uréia, 5 à fração solúvel, 6-9 referem-se as lavagens com 5, 20, 40 e $60 \mathrm{mM}$ imidazol, respectivamente. (B) M indica o padrão de massa molecular, 1-9 referem-se às frações 1 a 17 eluídas da coluna de $\mathrm{Ni}^{2+}$ sepharose, com $1 \mathrm{M}$ imidazol. A banda correspondente à HlyX (42,3 kDa) está indicada pela seta.

Quanto a purificação do fragmento N-terminal esta foi realizada em condições desnaturantes a partir da solubilização do corpúsculo de inclusão na solução $8 \mathrm{M}$ uréia. $\mathrm{Na}$ figura 16, pode-se observar que parte do fragmento N-terminal de LipL32 (8,9 kDa) foi eluído nas lavagens 40 e $60 \mathrm{mM}$ imidazol. A proteína também foi eluída nas frações de $1 \mathrm{M}$ imidazol (Figura 16B), porém nestas eluições as proteínas encontravam-se com contaminantes de $E$. coli. Sendo assim, somente as frações (lavagens 40 e $60 \mathrm{mM}$ imidazol) que possuíam o fragmento N-terminal purificado foram agrupadas e armazenadas a $4{ }^{\circ} \mathrm{C}$. 


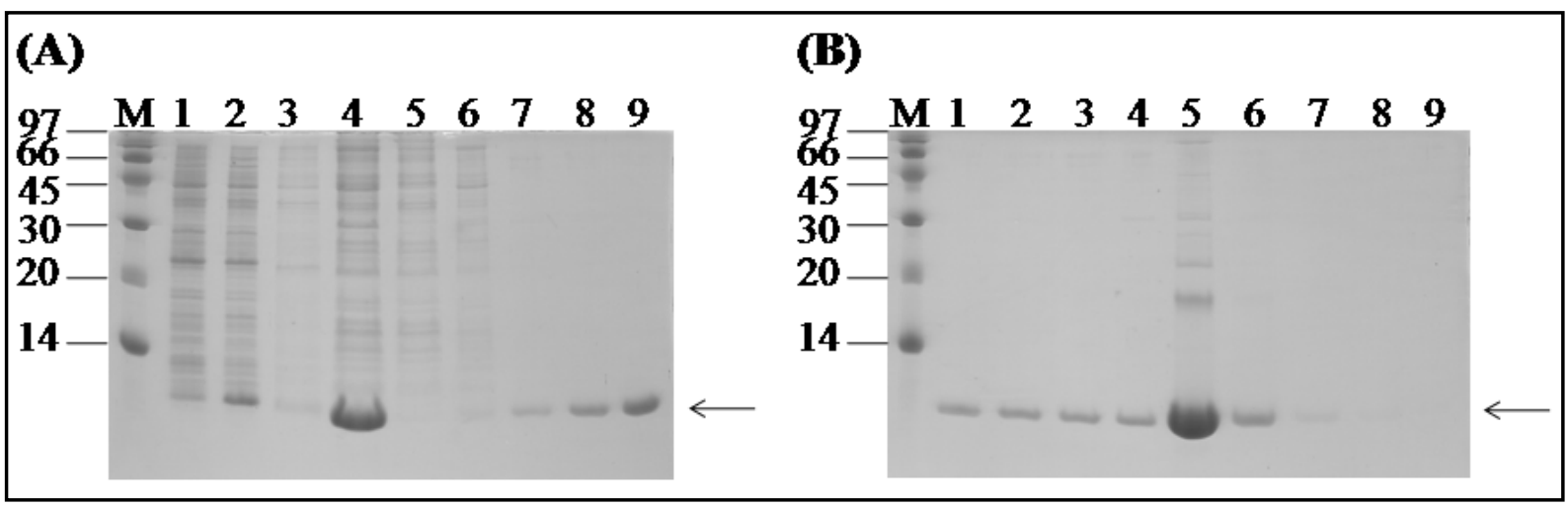

Figura 16 - SDS-PAGE 18\% da purificação do fragmento N-terminal de LipL32 em condições denaturantes, a partir dos corpúsculos de inclusão, solubilizados em solução $8 \mathrm{M}$ uréia, obtidos de extratos de E. coli recombinante induzida. (A) M refere-se ao marcador de massa molecular, 1 ao extrato de $E$. coli recombinante não induzido, 2 ao extrato de $E$. coli recombinante induzido, 3 à lavagem dos corpúsculos de inclusão com $1 \mathrm{M}$ uréia, 4 aos corpúsculos de inclusão solubilizados em solução $8 \mathrm{M}$ uréia, 5 à fração não adsorvida à coluna, 6-9 às lavagens com 5, 20, 40 e 60 mM imidazol. (B) M refere-se ao marcador de massa molecular, 1-9 indica às frações ímpares 1 a 17 eluídas da coluna $\mathrm{Ni}^{2+}$ sepharose. $\mathrm{O}$ fragmento $\mathrm{N}$-terminal $(8,9 \mathrm{kDa})$ está indicado pela seta.

\subsubsection{Purificação de LipL32 e LipL32 Se-M através de cromatografia de troca iônica e hidrofóbica}

Para a purificação das proteínas LipL32 e LipL32 Se-M a partir da fração solúvel, foram utilizadas cromatografias de troca iônica ( $Q$-sepharose e $S P$-sepharose) e hidrofóbica (Phenyl sepharose), pela ausência da cauda de histidina nestas proteínas que tem como objetivo estudos de estrutura tridimensional.

A resina aniônica ( $Q$-sepharose) foi utilizada apenas para a clarificação da amostra e eliminação de proteínas contaminates de E. coli que persistiam nos demais passos de purificação. Com relação a proteína LipL32 foi possível observar no gel de SDS 15\% (Figura 17) uma banda purificada que corresponde a aproximadamente a massa molecular teórica $(27,6 \mathrm{kDa})$ de LipL32 recombinante. Na figura 17A é possível verificar que apesar da baixa força iônica (20 mM trietanolamina, pH 7,8) da solução que contém a proteína recombinante, a eficiência da ligação de LipL32 à resina catiônica (SP-sepharose) foi baixa, pois LipL32 foi eluída já na primeira lavagem com $0,1 \mathrm{M} \mathrm{NaCl}$ em $20 \mathrm{mM}$ trietanolamina, pH 7,8 e grande parte da proteína recombinante pode ser encontrada na fração não adsorvida à coluna cromatográfica.

A partir da proteína purificada presente na lavagem $0,1 \mathrm{M} \mathrm{NaCl}$ em $20 \mathrm{mM}$ trietanolamina, $\mathrm{pH} 7,8$, obtida através da cromatografia catiônica, foi realizado o segundo passo de purificação de LipL32, que utilizou a cromatografia hidrofóbica (Phenyl sepharose). 
Para ser submetida à passagem pela coluna hidrofóbica foi necessário um acréscimo na concentração de $\mathrm{NaCl}$ na amostra, que passou de $0,1 \mathrm{M}$ para $3 \mathrm{M} \mathrm{NaCl}$. Na figura $17 \mathrm{~B}$ é possível verificar que a proteína liga-se fortemente à resina Phenyl sepharose nestas condições. A proteína LipL32 começou a ser eluída da coluna hidrofóbica após uma drástica diminuição de $\mathrm{NaCl}$ na coluna, $0,1 \mathrm{M} \mathrm{NaCl}$ em $20 \mathrm{mM}$ trietanolamina, $\mathrm{pH}$ 7,8. Nas lavagens onde não havia a presença de $\mathrm{NaCl}$ (20mM trietanolamina, $\mathrm{pH}$ 7,8 e água) a proteína ainda continuou a ser eluída pela diminuição das interações hidrofóbicas de LipL32 com a resina Phenyl sepharose.

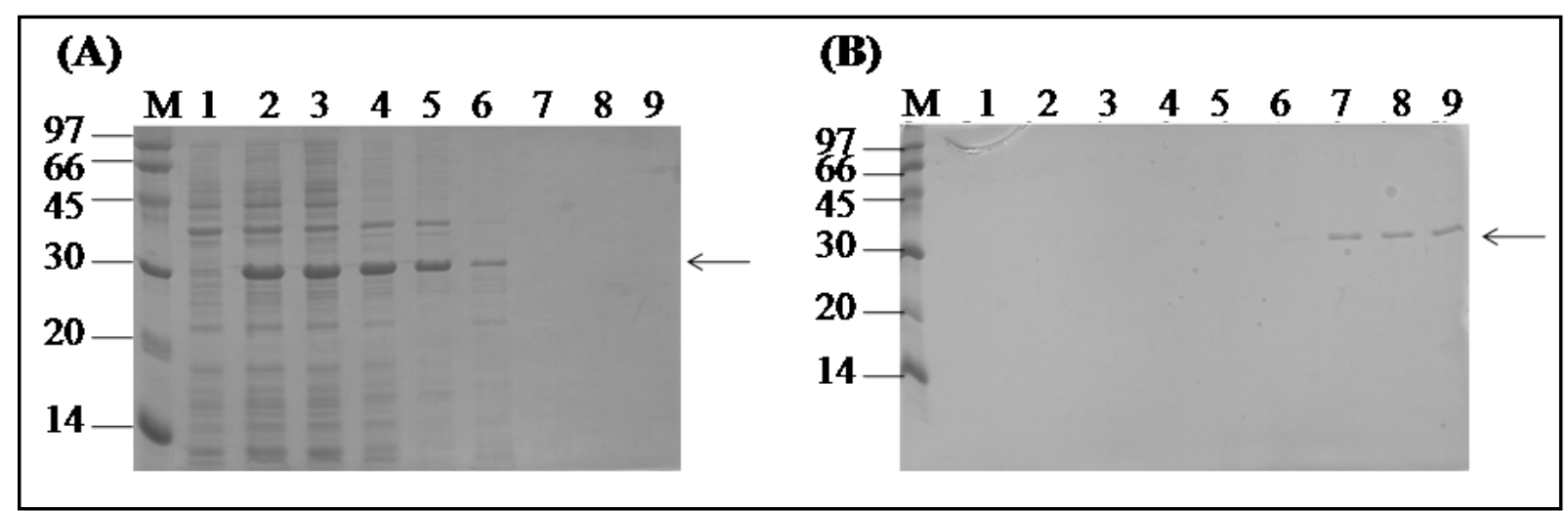

Figura 17 - SDS-PAGE 15\% da purificação de LipL32 a partir da fração solúvel de extratos de E. coli recombinante induzida. (A) refere-se a purificação realizada através da cromatografia catiônica (SP-sepharose); M refere-se ao marcador de massa molecular, 1 ao extrato de $E$. coli recombinante não induzido, 2 ao extrato de $E$. coli recombinante induzido, 3 à fração não adsorvida a resina $Q$-sepharose (amostra de entrada), 4 à fração não adsorvida ( $S P$ sepharose), 5-8 às lavagens $0,1,0,3,0,5$ e $0,7 \mathrm{NaCl}$, respectivamente e 9 à lavagem $1 \mathrm{M}$ $\mathrm{NaCl}$. (B) refere-se à purificação de LipL32, através da cromatografia hidrofóbica (Phenyl sepharose) a partir da lavagem $0,1 \mathrm{M} \mathrm{NaCl}$. $\mathrm{M}$ indica o marcador de massa molecular, 1-7 refere-se às lavagens $2,5 \mathrm{M}, 2,0 \mathrm{M}, 1,5 \mathrm{M}, 1,0 \mathrm{M}, 0,5 \mathrm{M}, 0,3 \mathrm{M}, 0,1 \mathrm{M} \mathrm{NaCl}$, respectivamente, 8 e 9 às eluições com $20 \mathrm{mM}$ trietanolamina, $\mathrm{pH} 7,8$ e àgua, respectivamente. A banda correspondente à LipL32 (27,5 kDa) está indicada pela seta.

LipL32 Se-M foi purificada de forma similar a LipL32, porém na figura 18A é possível visualizar um padrão de bandas contaminantes mais intenso na lavagem $0,1 \mathrm{M} \mathrm{NaCl}$ em 20 mM trietanolamina, pH 7,8, quando comparado com a purificação de LipL32 expressa em meio 2 YT ON com a resina $S P$-sepharose. Na figura $18 \mathrm{~A}$ pode-se observar que existem proteínas contaminantes na preparação com mais afinidade pela resina $S P$-sepharose do que a proteína recombinante, LipL32 Se-M. Apesar da intensa quantidade de bandas contaminantes presentes na eluição da proteína encontrados no primeiro passo de purificação (cromatografia catiônica) (Figura 18A), a purificação realizada na cromatografia hidrofóbica resultou em um grau de purificação satisfatório (Figura 19). Na figura 19A pode-se observar que LipL32, 
contendo metioninas marcadas com selênio, permanece interagindo fortemente com a coluna hidrofóbica, pois praticamente toda a proteína liga-se à coluna.

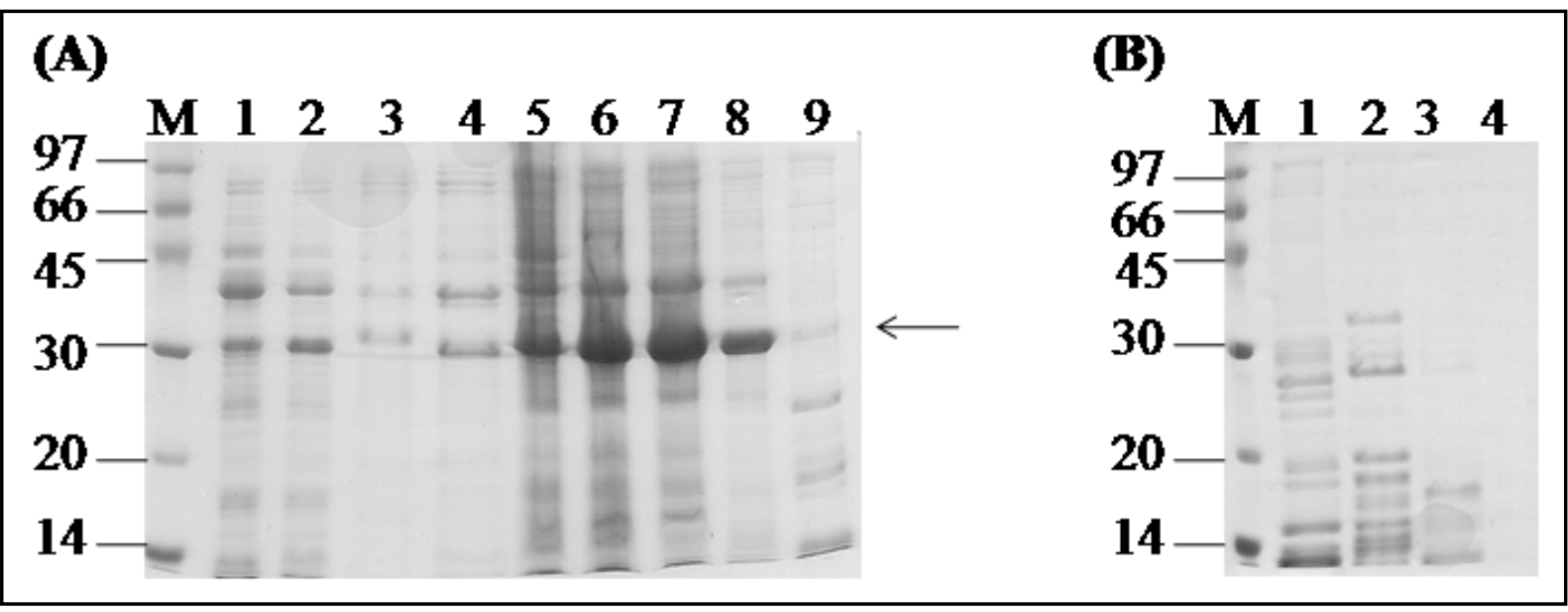

Figura 18 - SDS-PAGE 15\% da purificação de LipL32, através de cromatografia catiônica (SPsepharose) a partir da fração solúvel de E. coli recombinante induzida em meio mínimo (M9 ON), com adição de selênio metionina. $M$ indica o marcador de massa molecular, poço 1 refere-se ao extrato de $E$. coli recombinante não induzida, 2 ao extrato de $E$. coli recombinante induzida, 3 à lavagem do corpúsculo de inclusão com solução $1 \mathrm{M}$ uréia, 4 à solubilização do corpúsculo de inclusão com solução $8 \mathrm{M}$ uréia, 5 à fração solúvel, 6 à fração não adsorvida na resina $Q$-sepharose (amostra de entrada para a purificação), 7 à fração não adsorvida na $S P$-sepharose, 8 e 9 às lavagens com $0,1 \mathrm{M}$ e $0,3 \mathrm{M}$, respectivamente. (B) $\mathrm{M}$ indica o marcador de massa molecular e 1-4 correspondem às lavagens $0,5,0,7,1,0$ e 2,0 M NaCl em 20mM trietanolamina, $\mathrm{pH} 7,8$.

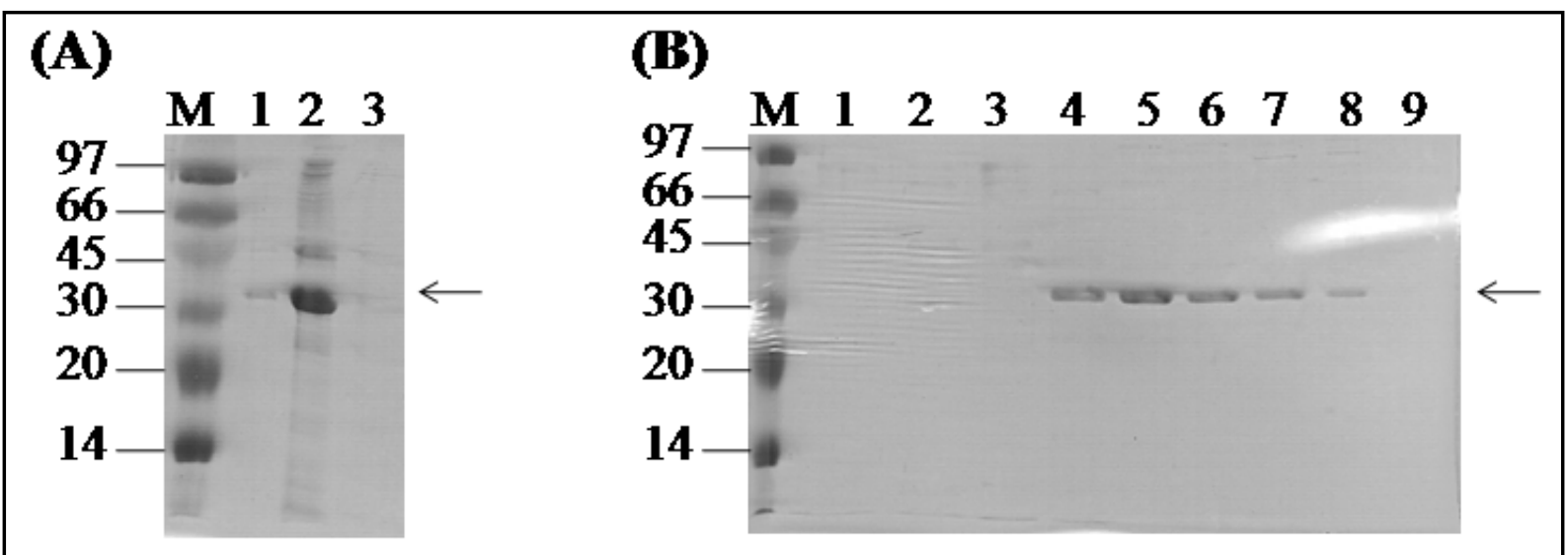

Figura 19 - SDS-PAGE 15\% da purificação de LipL32 através de cromatografia hidrofóbica (Phenyl sepharose), a partir da lavagem $0,1 \mathrm{M} \mathrm{NaCl}$ obtida na cromatografia catiônica ( $S P$ sepharose). (A) M indica a massa molecular, 1 refere-se à eluição com água, 2 à amostra de entrada $(0,1 \mathrm{M} \mathrm{NaCl})$ e 3 indica à fração não adsorvida. (B) $\mathrm{M}$ refere-se à massa molecular, 1-7 correspondem às lavagens 2,5, 2,0, 1,5, 1,0, 0,5, 0,3, 0,1 M NaCl em 20 $\mathrm{mM}$ trietanolamina, $\mathrm{pH} 7,8,8$ à lavagem $20 \mathrm{mM}$ trietanolamina, $\mathrm{pH}$ 7,8 e 9 ao poço sem amostra. 


\subsection{Análises de Western blot}

\subsubsection{Análise da conservação da expressão de LipL32 e HlyX em Leptospira sp. e caracterização dos fragmentos derivados de LipL32}

Para a análise da conservação das proteínas LipL32 e HlyX em Leptospira sp. foram utilizados os anticorpos gerados contra todas as proteínas purificadas, conforme item 3.14.1.

Com relação a conservação da expressão de LipL32 e HlyX em Leptopsira sp. foram visualizadas bandas correspondentes aos tamanhos esperados para estas proteínas em todos os extratos de sorovares patogênicos de L. interrogans testados (sorovares Canicola, Grippotyphosa, Pyrogenes, Pomona, Autumnalis, Hardjo, Bratislava, Copenhageni e Icterohaemorrhagiae) mas não no sorovar saprofítico, não patogênico L. biflexa sorovar Patoc (Figura 20). No caso de LipL32, foram utilizados anticorpos gerados contra LipL32 6xHis e LipL32.

Anticorpos foram gerados contra os fragmentos de LipL32, N-terminal, intermediário e C-terminal (Figura 21B) e mostraram ser específicos contra cada um dos fragmentos respecivamente (Figura 21). Estes anticorpos também reconheceram a proteína LipL32 nos extratos de Leptospira de diferentes sorovares patogênicos mas não na espécie saprofítica, $L$. biflexa (Figura 21B).

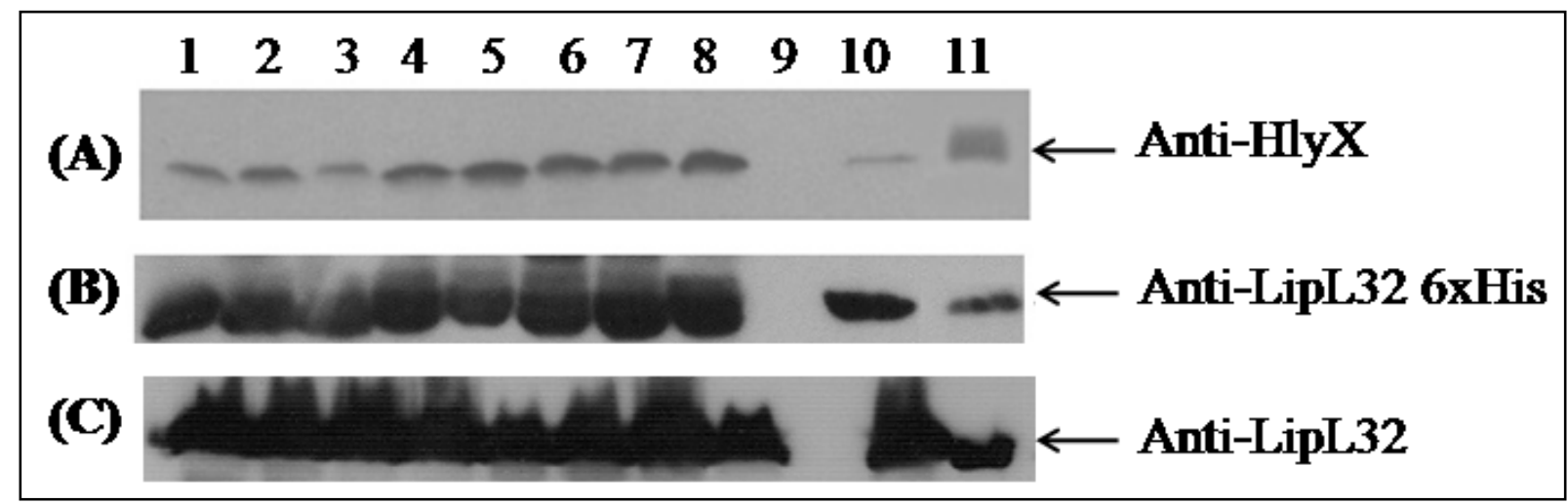

Figura 20 - Confirmação da identidade das proteínas purificadas através dos extratos celulares de diferentes sorovares de Leptospira interrogans analisados com anticorpos gerados contra as proteínas recombinantes, HlyX, LipL32 6xHis e LipL32. 1, Icterohaemorrhagiae; 2, Copenhageni; 3, Bratislava; 4, Hardjo; 5, Autumnalis 6, Pomona; 7, Pyrogenes; 8, L. kirchneri sorovar Grippotyphosa; 9, L. biflexa sorovar Patoc; 10, Canicola;11A, HlyX; 11B, LipL32 6xHis; 11C, LipL32. 


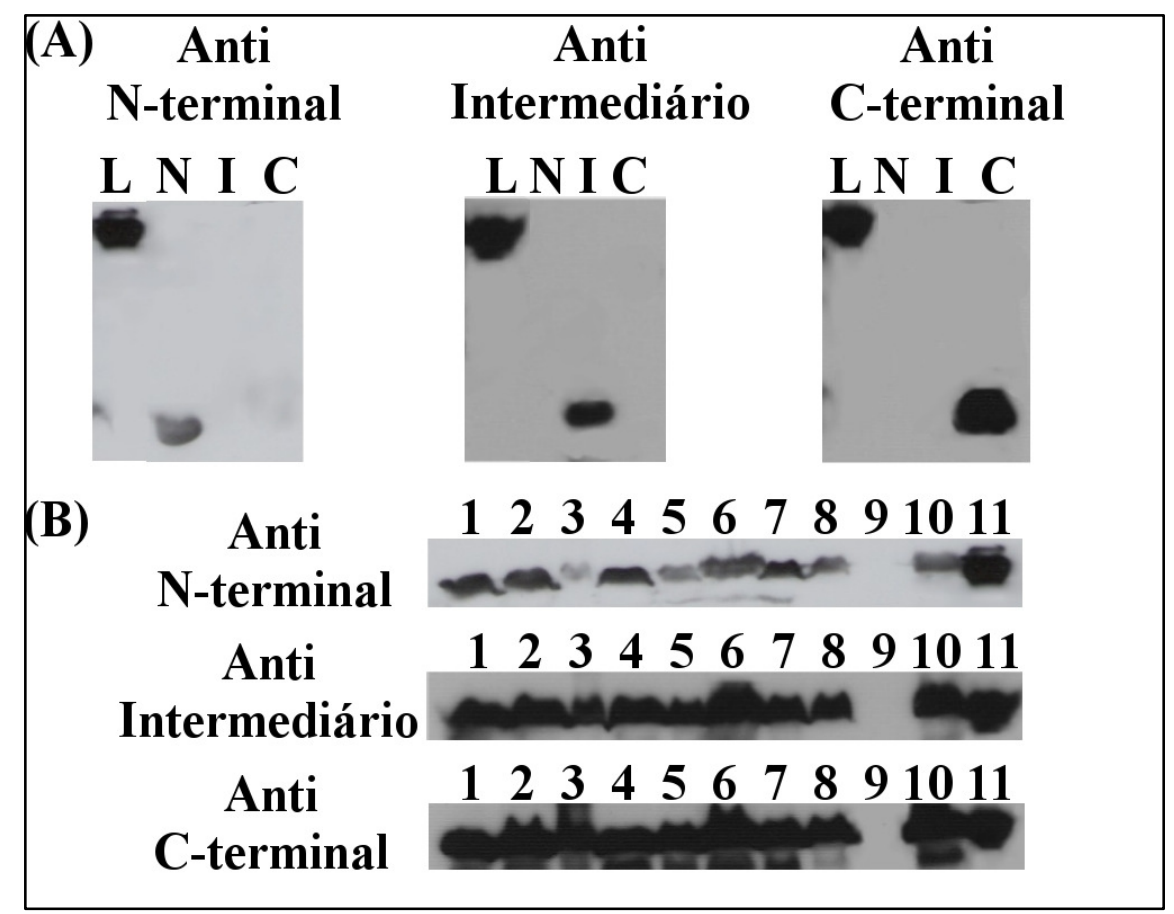

Figura 21 - Especificidade dos anticorpos gerados contra os fragmentos de LipL32. Soros de camundongos Balb/C fêmeas imunizados com os fragmentos de LipL32 reconheceram o fragmento correspondente (N, N-terminal; I, intermediário; C, C-terminal), bem como LipL32 (L, LipL32) (A), e LipL32 nativa dos extratos totais of L. interrogans sorovares Icterohaemorrhagiae (poço 1), Copenhageni (poço 2), Bratislava (poço 3), Hardjo (poço 4), Autumnalis (poço 5), Pomona (poço 6), Pyrogenes (poço 7), and Canicola (poço 8) and L. kirchneri sorovar Grippotyphosa (poço 10). Os soros também reconheceram a proteína recombinante (poço 11) mas não reagiram com o extrato total de L. biflexa sorovar Patoc (poço 9) (B).

\subsubsection{Detecção de anticorpos IgM e IgG dirigidos contra LipL32 e HlyX em soro de pacientes diagnosticados com leptospirose}

As análises de Western blot, demonstraram a presença de anticorpos $\operatorname{IgM}$ e $\operatorname{IgG}$ dirigidos contra LipL32 respectivamente, na fase aguda e na fase convalesente da doença. $\mathrm{Na}$ figura 22 pode-se verificar o reconhecimento de LipL32 por soros de pacientes com leptospirose confirmada, utilizando-se anti-IgM e anti-IgG.

Com relação aos resultados obtidos com a proteína HlyX foram observados somente anticorpos IgG dirigidos contra a proteína HlyX somente nos soros de pacientes coletados na segunda semana da doença (fase convalescente), com títulos de aglutinação microscópica de 25.600; 6.400, 3.200 e 1.600 (Figura 22). Não foram detectados anticorpos IgM dirigidos contra HlyX nos soros testados. 


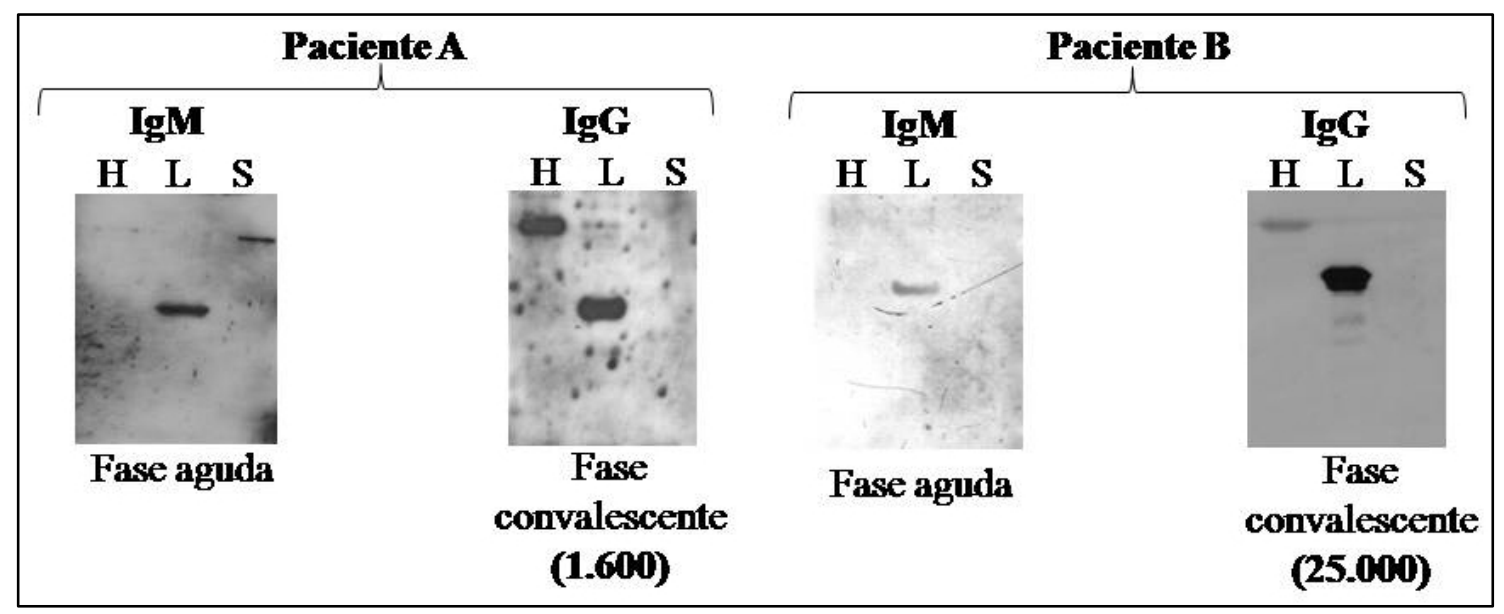

Figura 22 - Pesquisa de anticorpos IgM e IgG gerados contra as proteínas HlyX e LipL32. HlyX, H; LipL32 6xHis, L e Sm14, S (proteína ligante de ácidos-graxos de Schistosoma mansoni, usada como controle negativo), utilizando soros de pacientes com leptospirose (Paciente A e B). Os títulos de aglutinação microscópica dos soros de pacientes da fase aguda da doença não são detectáveis. Para a fase convalescente os títulos foram 1.600 para o paciente A e 25.600 para o paciente $\mathrm{B}$.

\section{Mapeamento do fragmento imunodominante de LipL32}

A partir dos resultados obtidos no item 4.4.2 foram realizadas análises utilizando-se a mesma técnica de detecção de anticorpos, Western blot, para o mapeamento da porção imunodominante da proteína LipL32. Para definir o fragmento imunodominante de LipL32, primeiramente utilizou-se o anticorpo gerado em camundongos contra LipL32 6xHis, conforme descrito no item 3.14.1, e o anticorpo anti-IgG de camundongo para a detecção. Os anticorpos gerados em camundongos contra a proteína inteira mostraram que o fragmento intermediário e C-terminal de LipL32 são os fragmentos com maior imunoreatividade (Figura 23A). A seguir, foram realizados ensaios utilizando-se soros de pacientes com leptospirose confirmada através de diagnóstico laboratorial (MAT positivo). Foram utilizados 12 pares de soros de pacientes, fases aguda (MAT negativo) e convalescente da infecção (MAT positivo), com diferentes títulos (Tabela 3). Em todos os casos foi detectada uma resposta IgM exclusivamente contra o fragmento $\mathrm{C}$-terminal, tanto na fase aguda como na fase covalescente (Tabela 3, Figura 23B).

Com relação à resposta $\operatorname{IgG}$ na fase aguda, o fragmento C-terminal foi reconhecido pelos anticorpos presentes no soros de 5 pacientes, e o fragmento intermediário reagiu com anticorpos IgG presentes em uma amostra de soro (Tabela 3). Durante a fase convalescente, anticorpos IgG de quase todas as amostras de soro reconheceram o fragmento intermediário, e anticorpos presentes em 5 das 12 amostras reconheceram o fragmento C-terminal (Tabela 3, 
Figura 23B). Em nenhuma das amostras de soro de paciente foi possível detectar anticorpos IgM e IgG contra o fragmento N-terminal de LipL32.

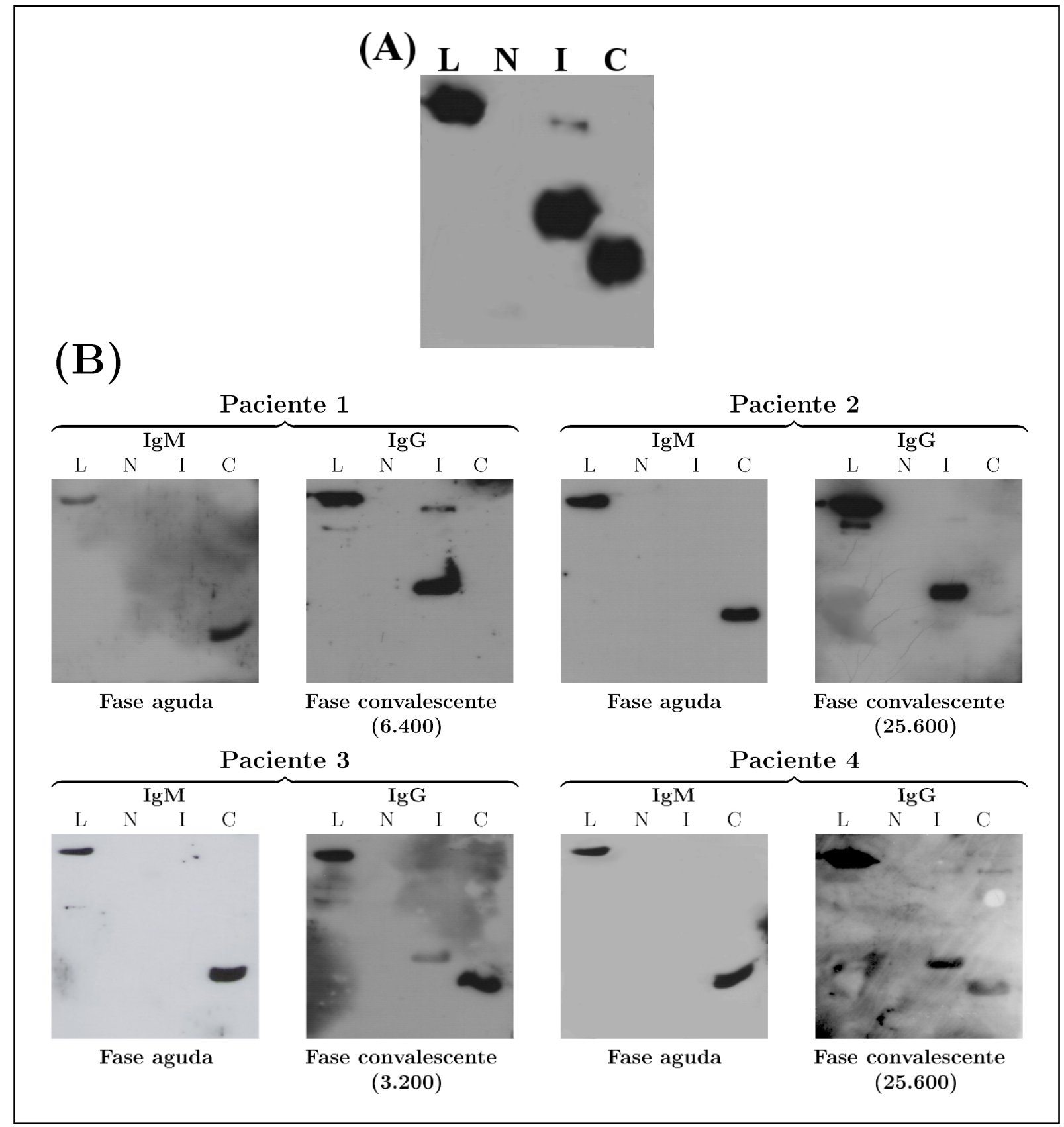

Figura 23 - Fragmentos de LipL32 recombinante e a reatividade com soro de camundongos (A) e com soro de pacientes com leptospirose (B). Análises de imunoblotting com os fragmentos de LipL32, N-terminal (N), intermediário (I), C-terminal (C), e LipL32 6xHis (L), utilizandose $2 \mu \mathrm{g}$ de cada proteína recombinante. As membranas de nitrocelulose foram incubadas com soro de camundongos imunizados com LipL32 6xHis recombinante (A) ou com soros obtidos de 4 pacientes com leptospirose 1 a 4 (Tabela 3) durante a fase aguda e convalescente da doença (B). Os blots foram realizados com anti-IgG de camundongo gerado em cabra conjugado a peroxidase (A) ou anti-IgM humano gerado em cabra conjugado a peroxidase (fase aguda) e anti- IgG humano gerado em cabra conjugado a peroxidase (fase convalescente) (B). Os títulos de MAT estão indicados para cada paciente. 
Tabela 3 - Títulos de MAT, início dos sintomas, sorovar infectante, e detecção de anticorpos nas amostras de soros de 12 pacientes com leptospirose ${ }^{\text {a }}$.

\begin{tabular}{|c|c|c|c|c|c|c|c|c|c|c|c|c|c|c|c|c|c|c|c|c|}
\hline \multirow{3}{*}{ Paciente } & \multicolumn{8}{|c|}{ Soros com reatividade IgM } & \multicolumn{8}{|c|}{ Soros com reatividade IgG } & \multirow{3}{*}{$\begin{array}{c}\text { Inverso } \\
\text { títulos } \\
\text { MAT } \\
\end{array}$} & \multirow{2}{*}{\multicolumn{2}{|c|}{$\begin{array}{l}\text { Dias após o início dos } \\
\text { sintomas }\end{array}$}} & \multirow{3}{*}{ Reatividade sorovar Leptospira } \\
\hline & \multicolumn{4}{|c|}{ Fase aguda } & \multicolumn{4}{|c|}{$\begin{array}{c}\text { Fase } \\
\text { convalescente }\end{array}$} & \multicolumn{4}{|c|}{ Fase aguda } & \multicolumn{4}{|c|}{$\begin{array}{c}\text { Fase } \\
\text { convalescente }\end{array}$} & & & & \\
\hline & $\mathbf{L}$ & $\mathbf{N}$ & $\mathbf{I}$ & $\mathbf{C}$ & $\mathbf{L}$ & $\mathbf{N}$ & $\mathbf{I}$ & $\mathbf{C}$ & $\mathbf{L}$ & $\mathbf{N}$ & I & $\mathbf{C}$ & $\mathbf{L}$ & $\mathbf{N}$ & $\mathbf{I}$ & $\mathbf{C}$ & & MAT(-) & MAT(+) & \\
\hline 1 & + & - & - & + & + & - & - & + & + & - & - & - & + & - & + & - & 6.400 & $\begin{array}{c}\text { Não } \\
\text { conhecido }\end{array}$ & $\begin{array}{c}\text { Não } \\
\text { conhecido }\end{array}$ & Icterohaemorrhagiae/Copenhageni \\
\hline 2 & + & - & - & + & + & - & - & + & + & - & - & + & + & - & + & - & 25.600 & 6 & 23 & Autumnalis \\
\hline 3 & + & - & - & + & + & - & - & + & + & - & - & - & + & - & + & - & 3.200 & 2 & 9 & Cynopteri \\
\hline 4 & + & - & - & + & + & - & - & + & + & - & - & + & + & - & + & + & 3.200 & 4 & 30 & Icterohaemorrhagiae \\
\hline 5 & + & - & - & + & + & - & - & + & + & - & - & - & + & - & + & + & 25.600 & 1 & 17 & Cynopteri \\
\hline 6 & + & - & - & + & + & - & - & + & + & - & - & - & + & - & + & - & 1.600 & 11 & 17 & Vários sorovares/inconclusivo \\
\hline 7 & + & - & - & + & + & - & - & + & + & - & - & - & + & - & + & - & 3.200 & 13 & 21 & Icterohaemorrhagiae \\
\hline 8 & + & - & - & + & + & - & - & + & + & - & - & + & + & - & - & - & 3.200 & 5 & 11 & Icterohaemorrhagiae/Copenhageni \\
\hline 9 & + & - & - & + & + & - & - & + & + & - & - & + & + & - & + & + & 1.600 & 6 & 14 & Copenhageni \\
\hline 10 & + & - & - & + & + & - & - & + & + & - & + & + & + & - & + & + & 1.600 & 4 & 9 & Copenhageni \\
\hline 11 & + & - & - & + & + & - & - & + & + & - & - & - & + & - & - & - & 6.400 & 4 & 17 & Autumnalis \\
\hline 12 & + & - & - & + & + & - & - & + & + & - & - & - & + & - & + & + & 6.400 & 6 & 31 & Icterohaemorrhagiae/Copenhageni \\
\hline
\end{tabular}

${ }^{a}$ L, LipL32 6xHis; N, N- terminal; I, intermediário; C, C-terminal 


\subsection{Análise da estrutura secundária de HlyX, LipL32 6xHis e LipL32}

As proteínas recombinantes HlyX, LipL32 6xHis e LipL32 apresentam as seguintes estruturas secundárias, segundo predições realizadas pelo programa Expasy: HlyX possui $56 \%$ de estrutura $\alpha$ - hélice, $2 \%$ de folha $\beta$-pregueada e $42 \%$ de estrutura randômica, enquanto LipL32 6xHis possui 63\% de estrutura randômica, $13 \%$ de folha $\beta$-pregueada e $23 \%$ de $\alpha$ hélice e LipL32 possui $60 \%$ de estrutura randômica, $15 \%$ de folha $\beta$-pregueada e $25 \%$ de $\alpha$ hélice. As análises de dicroísmo circular confirmam a predominância da estrutura $\alpha$-hélice em HlyX e a presença das estruturas $\alpha$ - hélice, folha $\beta$-pregueada e randômica para LipL32 6xHis e LipL32. No caso de LipL32 6xHis a predição do programa ExPASy estimou uma porcentagem maior de dobramentos randômicos (3\%) quando comparada com LipL32. Este aumento na porcentagem dos dobramentos randômicos são provenientes da sequência fusionada pelo vetor pDEST17 (Invitrogen). Dentre os 27 aminoácidos inseridos pelo vetor pDEST17 na região N-terminal de LipL32 6xHis, 22 aminoácidos estavam preditos para formação de estrutura randômica. Os resultados obtidos por dicroísmo circular com as proteínas LipL32 6xHis e LipL32 corroboram com a predição do programa ExPASy. A proteína LipL32 6xHis mostrou mais dobramentos aleatórios do que LipL32. Além disso, indica que o processo de renaturação da proteína HlyX foi bem sucedido. 


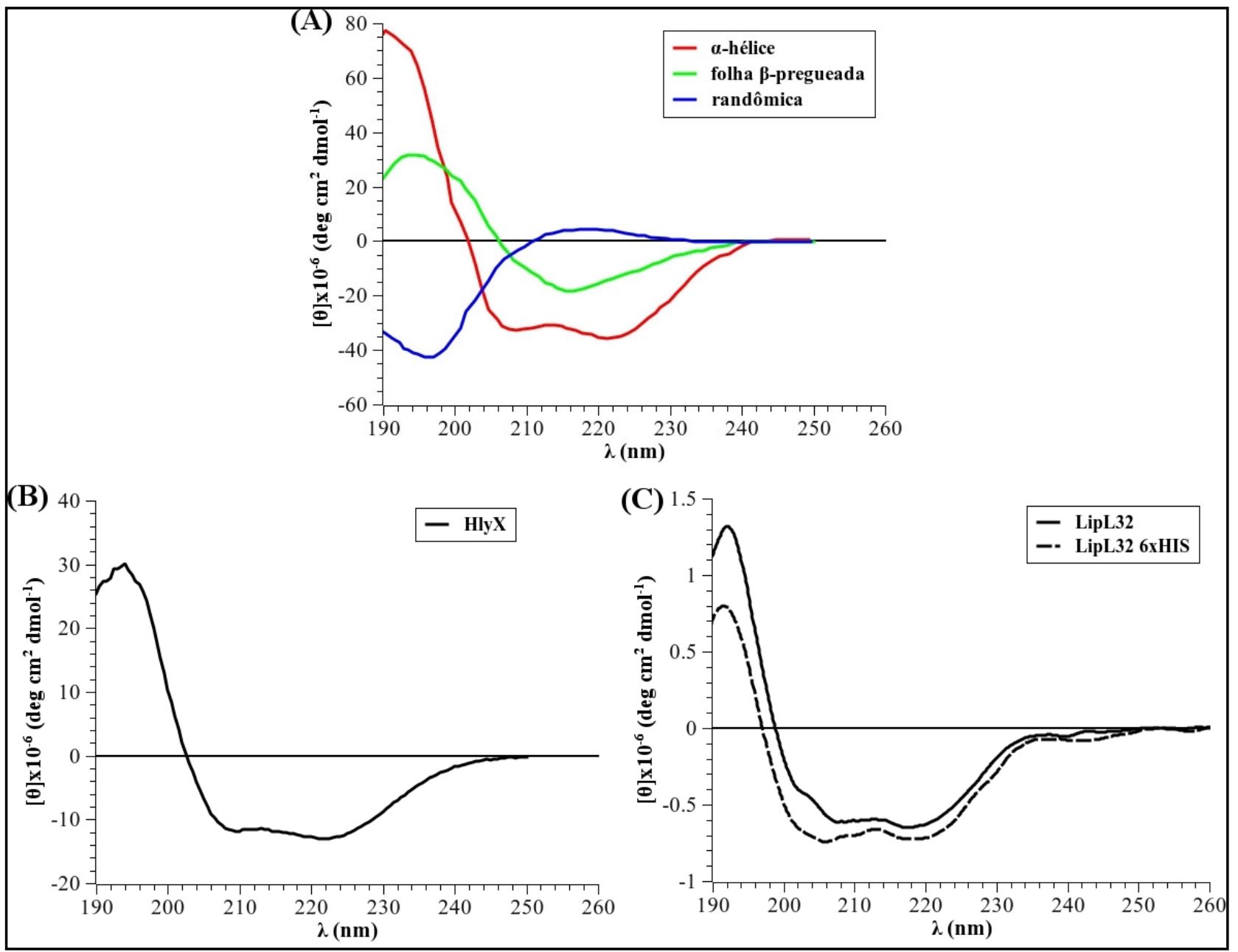

Figura 24 - Espectros de dicroísmo circular das proteínas recombinantes HlyX e LipL32 6xHis. Em (A) estão dispostas as curvas típicas de estrutura secundária de proteínas. A curva representada pelo espectro (B) representa a média das medidas da amostra de HlyX renaturada e (C) as médias das medidas obtidas com LipL32 6xHis e LipL32, ambas solúveis. As leituras foram obtidas através do espectropolarímetro, modelo J-810 (Jasco Inc.). 


\subsection{As proteínas LipL32 e HlyX interagem com proteínas do hospedeiro}

\subsubsection{As proteínas LipL32 e HlyX interagem com colágeno tipo IV e fibronectina plasmática}

Sendo LipL32 a proteína de superfície mais expressa durante a infecção, e HlyX uma proteína que possui domínios tetraticopeptídeos de interação proteína-proteína. Foram realizados experimentos para verificar se estas proteínas poderiam interagir com proteínas da matriz extracelular do hospedeiro, como laminina-1, colágeno tipo I, colágeno tipo IV, fibronectina celular e fibronectina plasmática.

As proteínas de matriz extracelular foram imobilizadas em placas de microtítulo, e as adesões de LipL32 6xHis e HlyX foram analisadas através de um método baseado em ELISA, descrito no item 3.15. Como mostrado na figura 25, tanto LipL32 6xHis como HlyX exibiram um significante nível de ligação a colágeno tipo IV $(P<0.0001)$ e a fibronectina plasmática $(P<0.0001)$. A proteína HlyX também exibiu ligação para colágeno tipo I $(P<0.0001)$ e para laminina-1 $(P<0.0001)$, mas optou-se por estudar as interações desta proteína com colágeno tipo IV e fibronectina plasmática, pois estas interações apresentaram-se mais intensas. A ligação de LipL32 às demais macromoléculas testadas não diferiu significativamente de sua ligação com fetuína, proteína utilizada como controle negativo (Figura 25). Também não foi detectada adesão da proteína codificada por LIC11030 ${ }^{(5)}$, utilizada como controle negativo, aos componentes de matriz extracelular (Figura 25).

Uma ligação dose-dependente à fibronectina plasmática e ao colágeno tipo IV foi observada quando se utilizaram concentrações cresentes de LipL32 (0 a $4 \mu \mathrm{M})$ e HlyX (0 a 2 $\mu \mathrm{M})$, mantendo-se fixas as quantidades de fibronectina plasmática e colágeno tipo IV $(1 \mu \mathrm{g})$ (Figuras 26A e 26D e 27A e 27D).

\footnotetext{
${ }^{(5)}$ A proteína codificada por LIC11030 foi gentilmente cedida pela Dr. Angela Silva Brarbosa. Esta proteína é predita como sendo uma proteína de membrana externa e foi purificada em condições semelhantes às da proteína LipL32.
} 


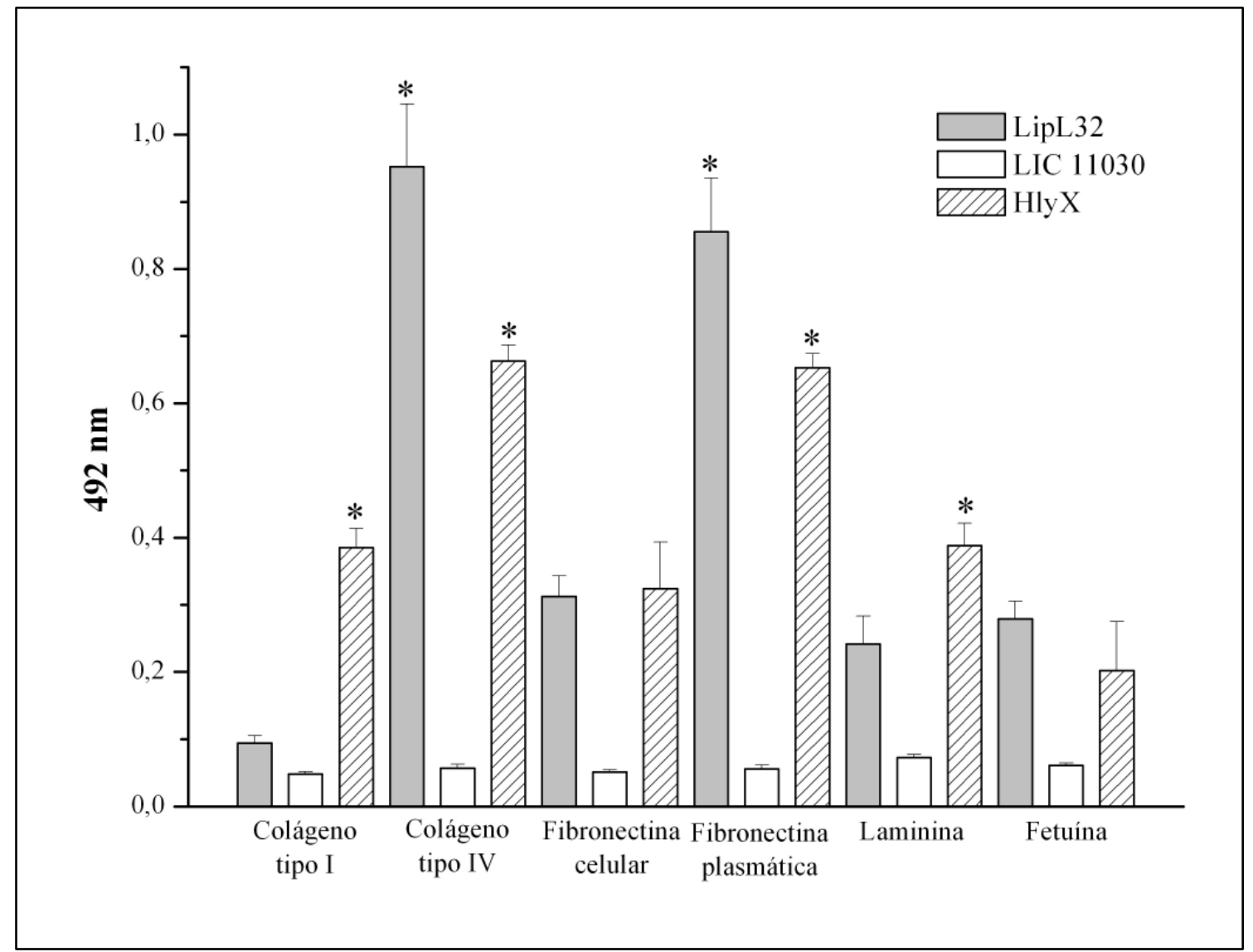

Figura 25 - Ligação de LipL32 6xHis e HlyX recombinantes a componentes de matriz extracelular e proteínas plasmáticas.Os poços foram revestidos com $1 \mu \mathrm{g}$ de laminina, colágeno tipo I, colágeno tipo IV, fibronectina celular, fibronectina plasmática, e fetuína, utilizada como proteína controle negativo. A adesão das proteínas recombinantes foi avaliada por um método baseado em ELISA. Um micrograma de cada proteína recombinante foi adicionada por poço. As densidades ópticas foram determinadas a $492 \mathrm{~nm}$. Os dados representam a média \pm o desvio padrão de 3 experimentos independentes, cada um realizado em triplicata. Para as análises estatísticas, a adesão de LipL32 6xHis e HlyX às macromoléculas foram comparadas com a ligação das proteínas recombinantes à fetuína através do $t$ teste $(*, P<0.0001)$. 
Foram realizados também experimentos para verificar se LipL32 6xHis e HlyX mostrariam adesões específicas aos fragmentos proteolíticos de fibronectina plamática F30 (30 kDa - domínio de ligação a heparina) e F45 (45 kDa - domínio de ligação a gelatina). Os resultados indicam que LipL32 6xHis interage com ambos os domínios da fibronectina testados de forma dose-dependente (Figura 26B, 26C) e HlyX interage somente com o domínio de ligação a heparina (F30) (Figura 27B), também de maneira dose-dependente. A ligação de HlyX ao domínio de ligação a gelatina (F45) não foi observada (Figura 27C).

Para se mapear a região de LipL32 responsável pela atividade de ligação ao componentes de matriz extracelular, foram realizados ensaios com os fragmentos C-terminal e intermediário. Como o fragmento N-terminal de LipL32 está em condições denaturantes (solução $8 \mathrm{M}$ uréia), este não foi incluído nos ensaios. Como mostrado na figura 26, o perfil de ligação do fragmento C-terminal à fibronectina plasmática e ao colágeno tipo IV assemelha-se ao perfil de ligação exibido por LipL32 6xHis a estas macromoléculas, indicando que a interação de LipL32 6xHis com a matriz é mediada pela sua porção Cterminal. $\mathrm{O}$ fragmento intermediário não foi capaz de aderir à fibronectina e ao colágeno tipo IV, mesmo em altas concentrações (Figura 26). 

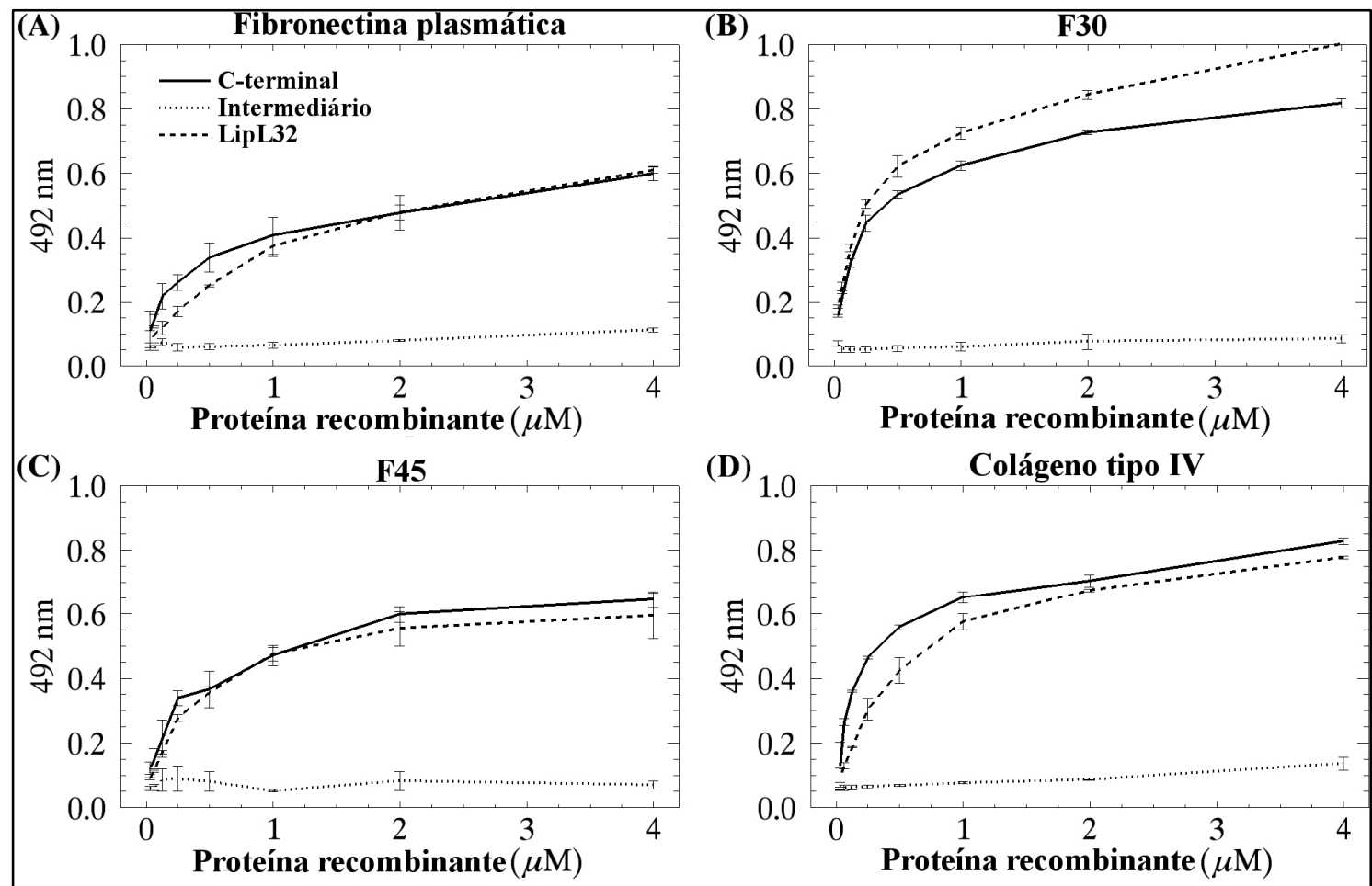

Figura 26 - Ligação de LipL32 6xHis e de seus fragmentos C-terminal e intermediário em fibronectina plasmática (molécula inteira e seus fragmentos proteolíticos, F30 e F45) e ao colágeno tipo IV em função da concentração de proteínas. A, ligação à fibronectina plasmática; B, ligação ao F30; C, ligação ao F45; D, ligação ao colágeno tipo IV. As concentrações de proteínas recombinantes variaram de 0 a $4 \mu \mathrm{M}$. Cada ponto representa a média dos valores de absorbância a $492 \mathrm{~nm} \pm$ o erro padrão de três experimentos independentes. 


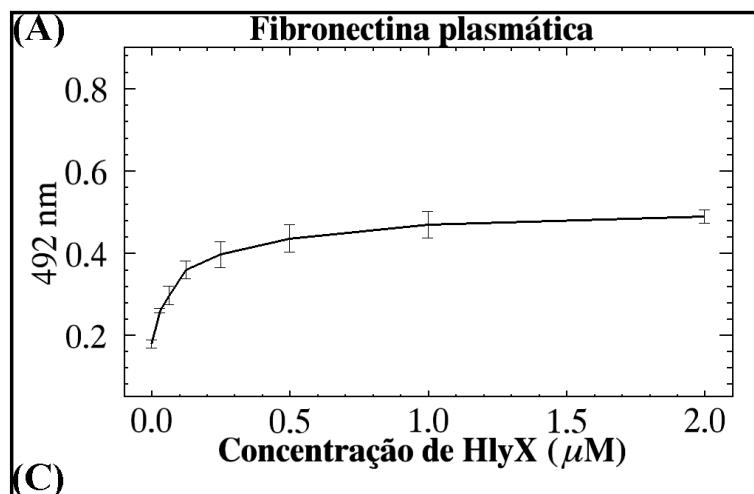

(C)

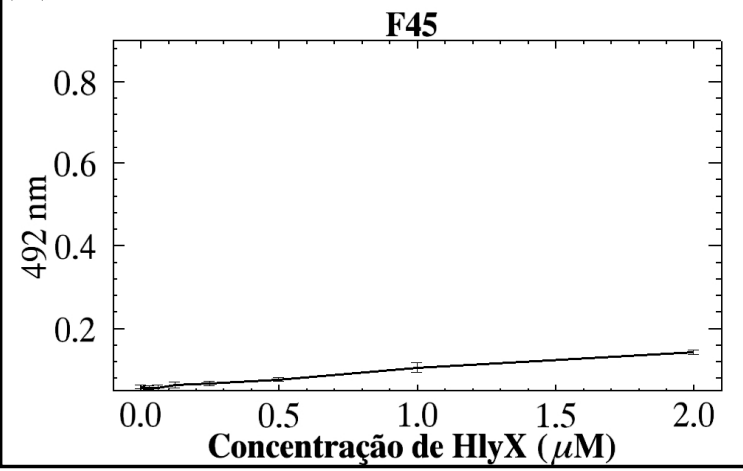

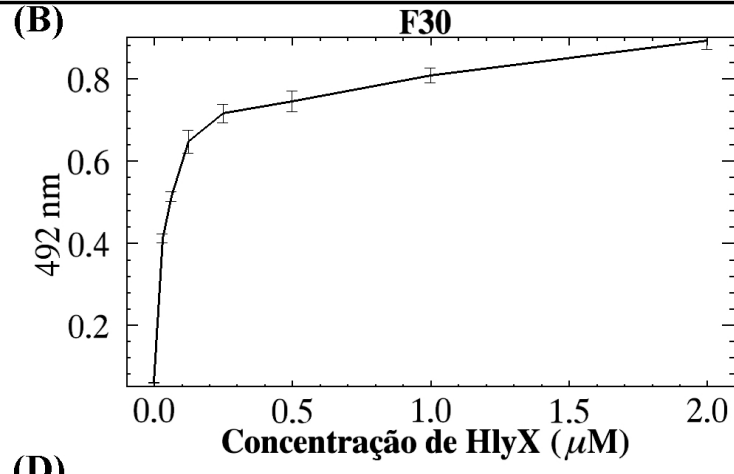

(D)

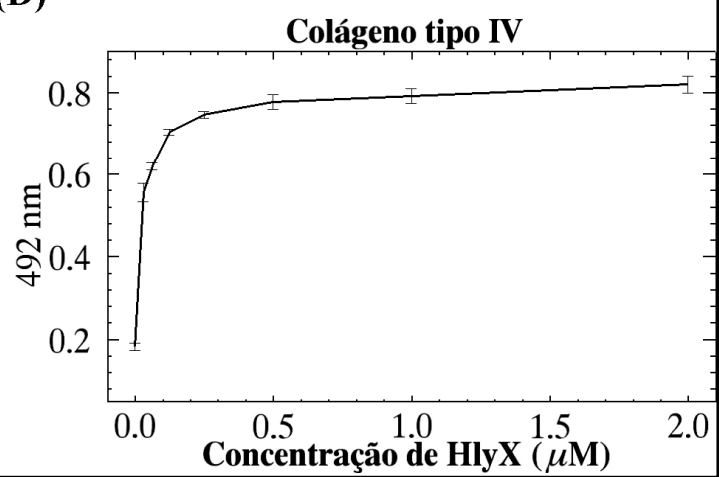

Figura 27 - Ligação de HlyX à fibronectina plasmática (molécula inteira e seu fragmento proteolítico, F30, mas não ao F45) e ao colágeno tipo IV em função da concentração. A, ligação à fibronectina plasmática; B, ligação ao F30; C, ligação ao F45; D, ligação ao colágeno tipo IV. As concentrações da proteína recombinante variaram de 0 a $2 \mu \mathrm{M}$. Cada ponto representa a média dos valores de absorbância a $492 \mathrm{~nm} \pm$ o erro padrão de três experimentos independentes.

Os $K_{d}$ s aparentes para a ligação de LipL32 e HlyX a fibronectina plasmática e colágeno tipo IV estão apresentados na tabela 4 . O valor da $K_{d}$ obtidos para a ligação de LipL32 à fibronectina plasmática foi de 99 nM e para a ligação de LipL32 aos domínios F30 e F45 os valores de $K_{d}$ s alcançaram os valores de 107 e $138 \mathrm{nM}$, respectivamente. Valores similares foram encontrados para o fragmento C-terminal. Já os $K_{d}$ s obtidos para colágeno tipo IV em relação a LipL32 e seu fragmento C-terminal alcançaram valores de 167 e 156 nM, respectivamente. A proteína HlyX apresentou baixos valores de $K d$ s aparentes quando comparada a LipL32 (Tabela 4). A ligação de HlyX a fibronectina plasmática e seu domínio F30 alcançou valores de 25 e $51 \mathrm{nM}$, respectivamente. $\mathrm{O}$ valor da $K_{d}$ obtido para a ligação com colágeno tipo IV, mostrou uma alta afinidade, $14 \mathrm{nM}$. A análise das $K_{d} \mathrm{~s}$ encontrados para a ligação das proteínas LipL32 e HlyX, para as moléculas estudadas, permite afirmar que a afinidade da proteína HlyX é maior quando comparada à de LipL32 (Tabela 4). 
Tabela $4-K_{d}$ s relativas à ligação de LipL32, do fragmento C-terminal de LipL32 e de HlyX à fibronectina plasmática e ao colágeno tipo IV. O valor entre parênteses representa o erro padrão experimental.

\begin{tabular}{ccccc}
\hline Proteínas & \multicolumn{4}{c}{$K_{d}(\mathbf{n M})$} \\
\cline { 2 - 5 } ligantes & Fibronectina Plasmática & F30 & F45 & Colágeno tipo IV \\
\hline LipL32 & $\mathbf{9 9}( \pm \mathbf{1 1})$ & $\mathbf{1 0 7}( \pm \mathbf{5})$ & $\mathbf{1 3 8}( \pm \mathbf{1 1})$ & $\mathbf{1 6 7}( \pm \mathbf{1 2})$ \\
C-terminal & $\mathbf{9 6}( \pm \mathbf{5})$ & $\mathbf{1 0 9}( \pm \mathbf{4})$ & $\mathbf{1 0 1}( \pm 7)$ & $\mathbf{1 5 6}( \pm \mathbf{6})$ \\
HlyX & $\mathbf{2 5}( \pm \mathbf{1})$ & $\mathbf{3 3}( \pm \mathbf{1})$ & ND $^{*}$ & $\mathbf{1 4}( \pm \mathbf{1})$ \\
\hline
\end{tabular}

ND* Não determinado.

4.6.2 O fragmento C-terminal compete com LipL32 pela ligação ao colágeno tipo IV e à fibronectina plasmática

De acordo com os resultados descritos acima, o fragmento C-terminal de LipL32 ligase a ambos os domínios de fibronectina, F30 e F45, e ao colágeno tipo IV de forma dosedependente. Com a intenção de identificar a região envolvida nesta interação, ensaios de competição foram realizados usando-se concentrações crescentes dos fragmentos C-terminal ou intermediário (0 to $7 \mu \mathrm{M})$ na presença de uma concentração fixa de LipL32 $(1,5 \mu \mathrm{M})$.

A ligação aos componentes de matriz extracelular foi realizada essencialmente como descrito acima. Anticorpos anti-intermediário de LipL32 foram utilizados quando quantidades crescentes de fragmento C-terminal foram usados no ensaio de competição e anticorpos antiC-terminal foram utilizados quando quantidades crescentes de fragmento intermediário foram usados com o mesmo propósito. Essa estratégia permitiu detectar a ligação de LipL32 a componentes de matriz em ambos os casos. Uma inibição dose-dependente da ligação de LipL32 a colágeno tipo IV, F30 e F45 foi alcançada quando quantidades crescentes do fragmento C-terminal foram usadas, indicando que este domínio compete pela ligação de LipL32 a estes componentes de matriz extracelular. Além disso, a inibição da ligação não ocorreu aumentando-se as quantidades do fragmento intermediário (Figura 28). 


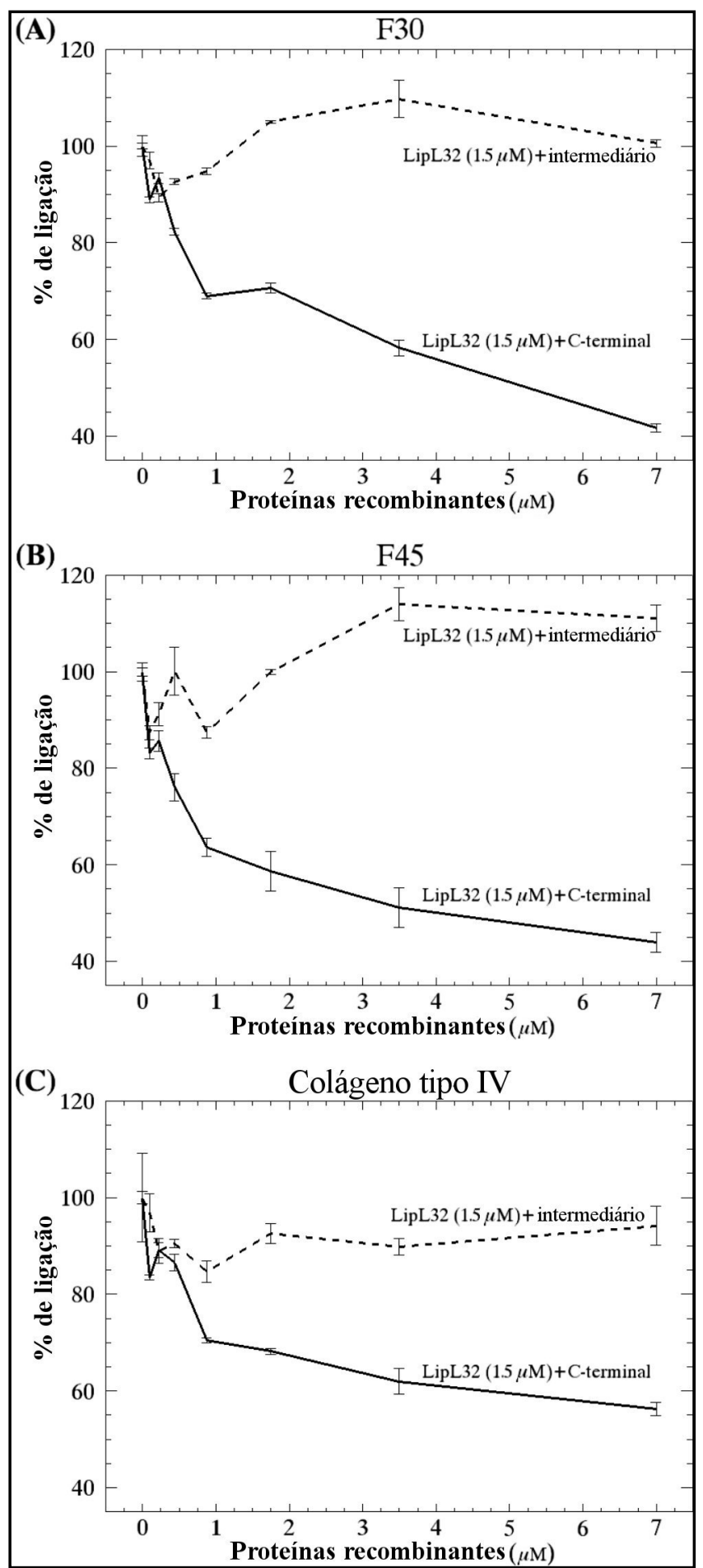

Figura 28 - Inibição da ligação de LipL32 aos fragmentos proteolíticos F30 e F45 e ao colágeno tipo IV pelo fragmento C-terminal de LipL32. Os poços foram revestidos com F30 (A), F45 (B), ou colágeno tipo IV (C), e concentrações crescentes dos fragmentos C-terminal ou intermediário $(0$ to $7 \mu \mathrm{M})$ foram adicionadas na presença de uma concentração fixa de LipL32 $(1,5 \mu \mathrm{M})$. As densidades ópticas foram determinadas a $492 \mathrm{~nm}$. Os dados representam a média \pm o erro padrão de três experimentos independentes, cada experimento foi realizado em triplicata. 


\subsubsection{Competição de LipL32, do fragmento C-terminal de LipL32 e de HlyX com os ligantes de F30 (heparina) ou F45 (gelatina)}

Como já mencionado, F30 e F45 são fragmentos proteolíticos de fibronectina que contêm domínios que se ligam a heparina e gelatina, respectivamente. Com os domínios de fibronectina imobilizados, utilizou-se $2 \mu \mathrm{M}$ de LipL32 ou do fragmento C-terminal na presença de quantidades crescentes de heparina ( 0 a 500 UI) ou gelatina (0 a $50 \mu \mathrm{g}$ ). Para os ensaios envolvendo a proteína HlyX, também foram utilizados $2 \mu \mathrm{M}$ de proteína na presença de quantidades crescentes de heparina ( 0 a 500 UI). Tanto a heparina quanto a gelatina foram capazes de inibir a ligação de LipL32 e do fragmento C-terminal aos domínios F30 e F45 de maneira dose-dependente (Figura 29).

O padrão de inibição obtido com gelatina foi bastante similar quando se utilizou LipL32 intacta ou o fragmento C-terminal, e uma inibição quase completa foi observada com baixas concentrações de gelatina (Fig. 29B). Entretanto, a heparina não foi capaz de inibir completamente a interação de LipL32 a F30, embora a ligação do fragmento C-terminal a este domínio tenha sido abolido com sucesso. É possível que a interação de LipL32 com fibronectina envolva outras regiões da molécula (Figura 29A).

De fato, como demonstrado na figura 26B a ligação de LipL32 em F30 foi significativamente maior do que a exibida pelo fragmento C-terminal. Em conclusão, LipL32 interage com fibronectina principalmente através de sua porção C-terminal, e a ligação coincide susbstancialmente ou se co-localiza com os sítios de ligação a heparina e gelatina.

Os resultados obtidos com a proteína HlyX, mostraram que a ligação da proteína ao domínio de heparina é específico, pois a heparina em concentrações crescentes, conseguiu inibir a ligação de HlyX ao domínio F30 (Figura 30). 

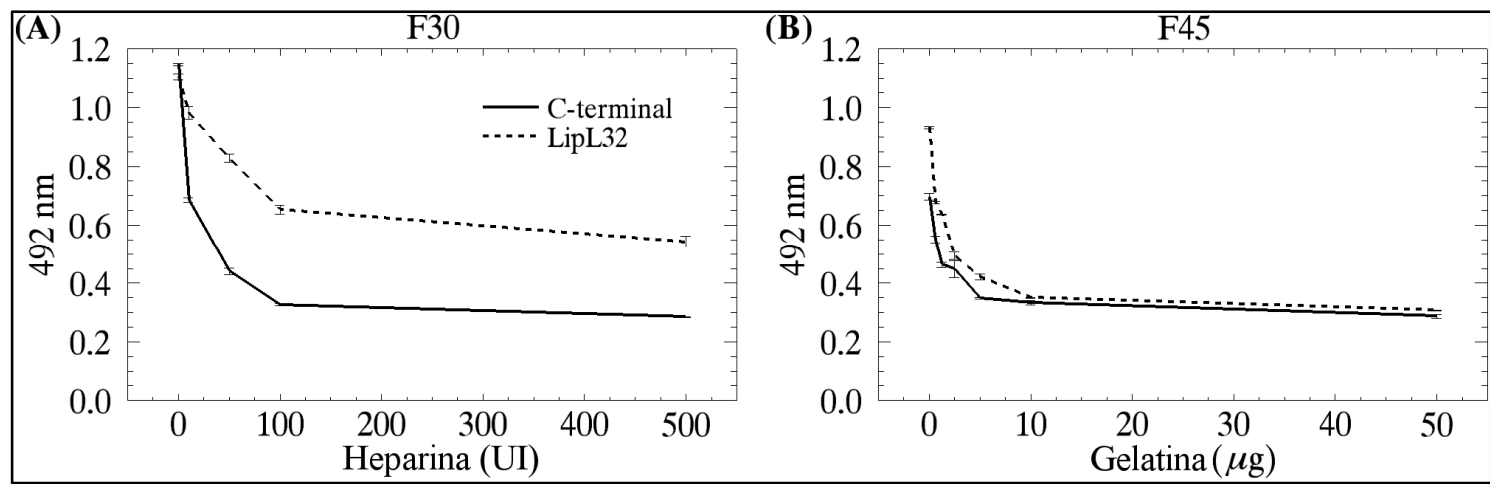

Figura 29 - Inibição da ligação de LipL32 aos fragmentos proteolíticos de fibronectina plasmática F30 e F45 por heparina e gelatina, respectivamente. A ligação de LipL32 e seu fragment Cterminal $(2 \mu \mathrm{M})$ a F30 (A) e F45 (B) foi realizada na presença de quantidades crescentes de heparina (0 a $500 \mathrm{UI})$ ou gelatina $(0$ to $50 \mu \mathrm{g})$. As densidades ópticas foram determinadas a $492 \mathrm{~nm}$. Os dados representam a média \pm o erro padrão de três experimentos independentes.

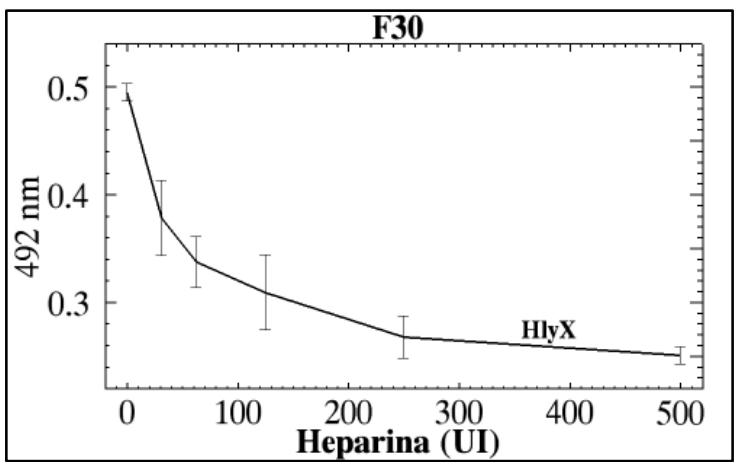

Figura 30 - Inibição da ligação de HlyX ao domínio de ligação da fibronectina plasmática a heparina. A ligação de HlyX $(2 \mu \mathrm{M})$ a F30 (A) foi realizada na presença de quantidades crescentes de heparina ( 0 a 500 UI). As densidades ópticas foram determinadas a $492 \mathrm{~nm}$. Os dados representam a média \pm o erro padrão de três experimentos independentes. 


\subsection{Ensaio de proteção contra desafio homólogo}

Nos ensaios de imunização e desafio em modelo animal utilizados para leptospirose, a proteína HlyX foi injetada subcutâneamente em hamsters para verificar se o antígeno possuía habilidade de conferir proteção em hamsters infectados com a cepa virulenta, Leptospira interrogans sorovar Copenhageni. As análises dos ensaios de níveis de IgG por ELISA de um único experimento realizado independentemente, mostram que as proteínas HlyX, LipL32 e o fragmento C-terminal de LigA (resíduos de aa 817-1224 aa) geraram títulos de anticorpos, respectivamente em torno de 1:128.000 (Figura 31), 1:16.000 (Figura 32) e 1:64.000 (Figura 33). A dispersão dos títulos de IgG obtidos com os soros individuais dos animais de cada grupo vacinado e a mediana de títulos de $\operatorname{IgG}$ de cada grupo vacinado estão mostrados nas figuras 31,32 e 33 .

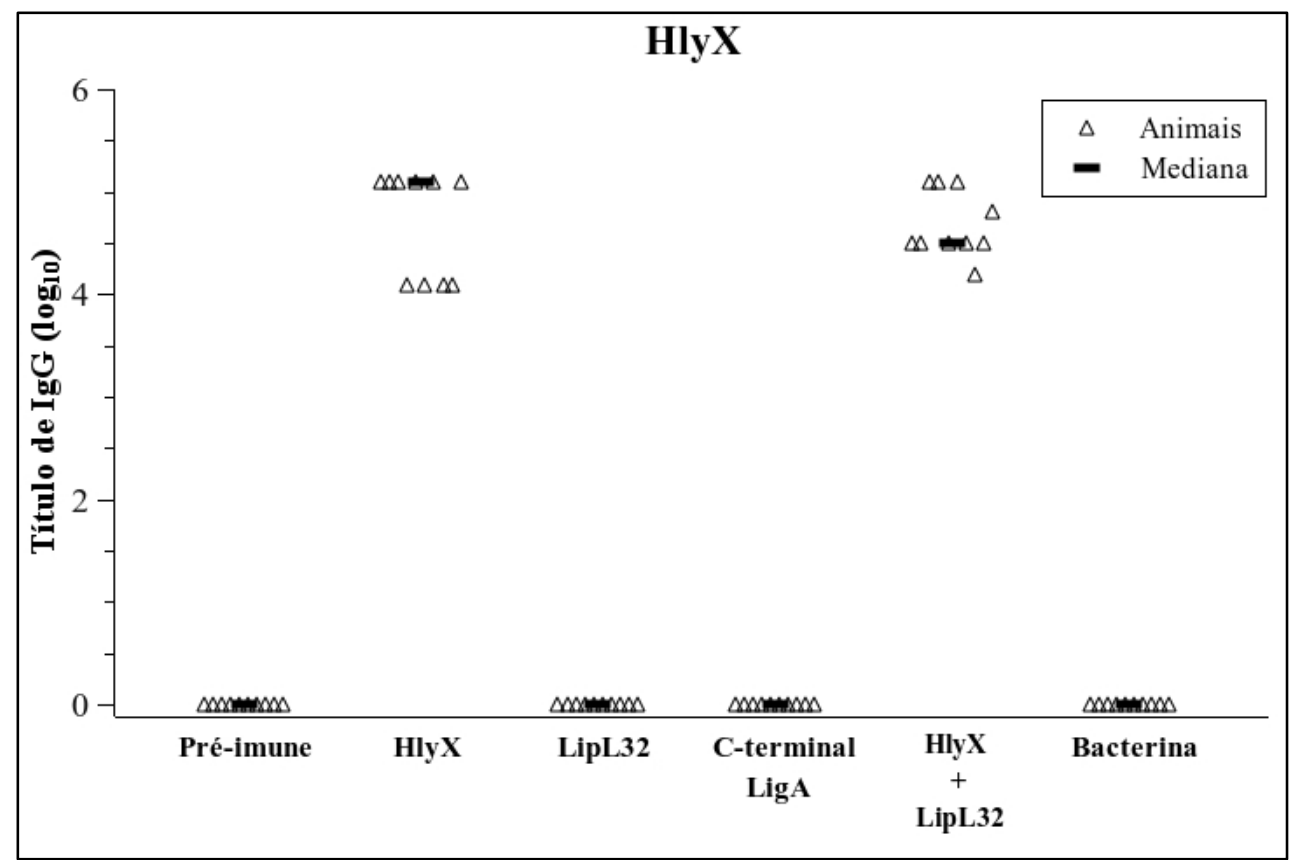

Figura 31 - Títulos de anticorpos IgG gerados contra a proteína HlyX, obtidos em um único experimento realizado. Neste gráfico os títulos de $\mathrm{IgG}$ anti-HlyX observados nos animais individualmente estão representados pelos triângulos e a mediana destes valores estão indicadas pelos traços em negrito. 


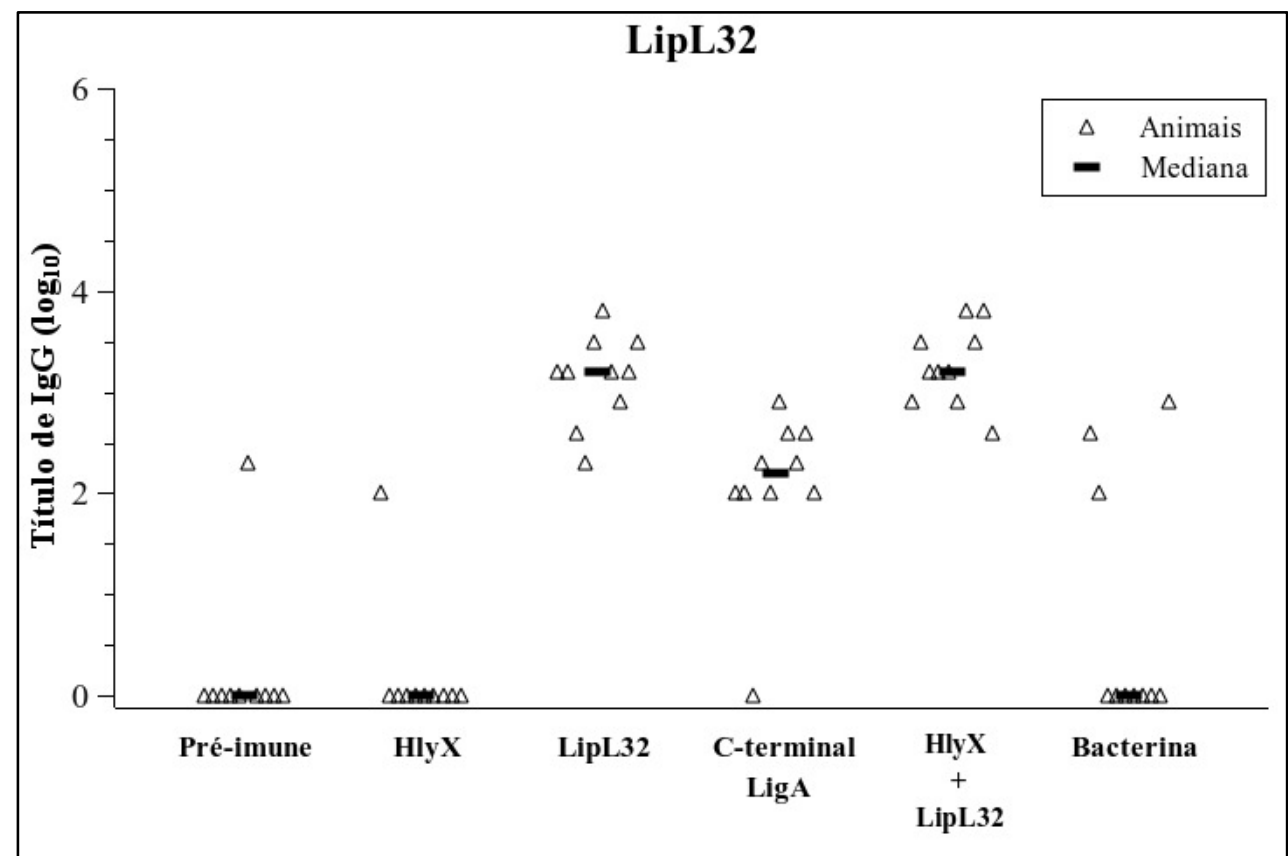

Figura 32 - Títulos de anticorpos IgG gerados contra a proteína LipL32, obtidos em um único experimento realizado. Neste gráfico os títulos de IgG anti-LipL32 observados nos animais individualmente estão representados pelos triângulos e a mediana destes valores estão indicadas pelos traços em negrito.

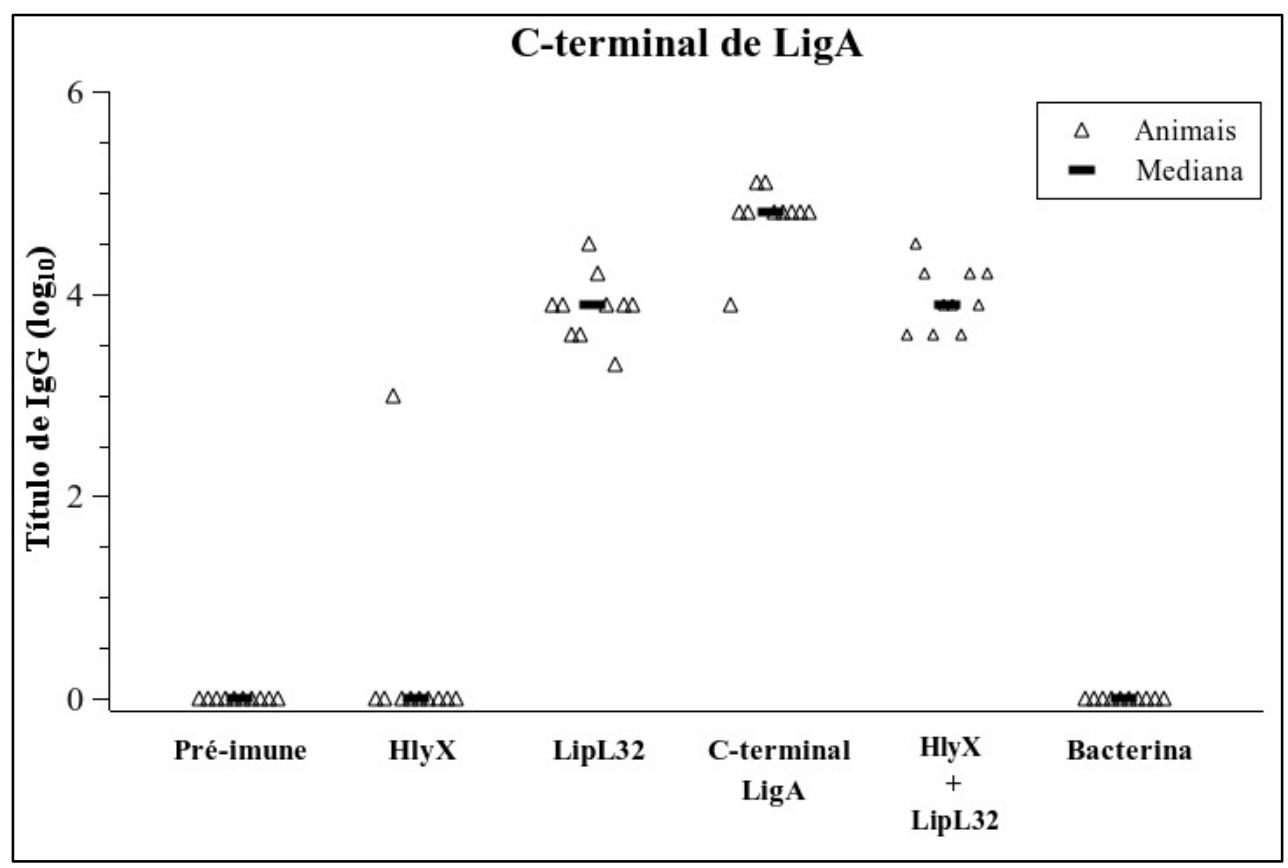

Figura 33 - Títulos de anticorpos IgG gerados contra o fragmento C-terminal de LigA, obtidos em um único experimento realizado. Neste gráfico os títulos de IgG anti-C-terminal de LigA observados nos animais individualmente estão representados pelos triângulos e a mediana destes valores estão indicadas pelos traços em negrito. 
Os títulos de IgG anti-HlyX induzidos nos animais imunizados com a proteína HlyX foram estatisticamente diferentes dos títulos encontrados com os soros pré-imunes de todos os grupos de animais estudados e dos soros dos animais inoculados com a bacterina, fragmento C-terminal de LigA ou com LipL32 ( $<<0.001)$. Não houve diferença de anticorpos entre os títulos encontrados nos animais inoculados com HlyX e HlyX em co-administração com LipL32 ( $\mathrm{p}>0.9681$ ). Os títulos de anticorpos encontrados no grupo bacterina e nos soros préimunes de todos os grupos vacinados foram menores que 1:1000 e muito inferiores aos encontrados para HlyX. Os animais imunizados com LipL32 e com o fragmento C-terminal de LigA não apresentaram títulos de IgG detectáveis contra a proteína HlyX.

Para LipL32 os títulos de IgG induzidos nos animais imunizados com esta proteína foram estatisticamente diferentes dos títulos encontrados nos soros pré-imunes de todos os grupos de animais estudados e dos soros dos animais inoculados com a bacterina, C-terminal de LigA ou com HlyX (p<0.05). Não houve diferença de anticorpos entre o grupo vacinado com LipL32 e HlyX em co-administração com LipL32 (p>0.05). Nos soros pré-imunes de todos os grupos vacinados os títulos de anticorpos encontrados foram menores que 1:100. Os animais imunizados com o fragmento C-terminal de LigA apresentaram títulos detectáveis de IgG contra a proteína LipL32, mostrando uma reatividade cruzada do C-terminal de LigA com LipL32. Porém, apesar desta reatividade cruzada os títulos observados nos animais imunizados com LipL32 e HlyX em co-administração com LipL32 foram estatisticamente diferentes dos títulos observados nos animais imunizados com o fragmento C-terminal de $\operatorname{LigA}(\mathrm{p}<0.05)$.

Os títulos de IgG anti-C-terminal de LigA nos animais imunizados com este fragmento da proteína LigA foram estatisticamente diferentes dos títulos encontrados nos animais imunizados com a proteína HlyX $(\mathrm{p}<0.001)$. Os títulos de anticorpos encontrados no grupo bacterina e nos soros pré-imunes de todos os grupos vacinados foram menores que 1:1000 e muito inferiores aos encontrados no grupo imunizado com a porção C-terminal de LigA. Interessantemente, os animais imunizados com LipL32 e HlyX em co-administração com LipL32 apresentaram títulos detectáveis de absorbância contra o fragmento C-terminal de LigA, mostrando o mesmo perfil de reatividade cruzada do fragmento C-terminal de LigA com LipL32. Porém, apesar desta reatividade cruzada os títulos de anticorpos nos animais imunizados com LipL32 e HlyX em co-administração com LipL32 foram estatisticamente diferentes dos títulos obtidos pela imunização dos animais com o fragmento C-terminal de $\operatorname{LigA}(\mathrm{p}<0.05)$. 
Quanto a proteção conferida pelas proteínas recombinantes utilizando hidróxido de alumínio como adjuvante, as proteínas HlyX e LipL32 administradas isoladamente demonstraram diferentes resultados. A imunização subcutânea com HlyX não foi capaz de conferir proteção em animais desafiados com leptospiras virulentas (20\% de proteção). Por outro lado, a imunização com LipL32 conferiu $80 \%$ de proteção (Figura 34). Já o grupo vacinado com HlyX em co-administração com LipL32 demonstrou a mesma capacidade protetora do controle positivo de vacina recombinante, o fragmento C-terminal de LigA e da bacterina, ou seja, $100 \%$ dos animais vacinados sobreviveram ao desafio homólogo com leptospiras virulentas (Figura 34). Os animais vacinados e desafiados que sobreviveram até o dia 58 foram sacrificados e tiveram seus fígados coletados para análise quanto a presença de leptospiras in vitro. Na tabela 5 pode-se verificar que todos os animais vacinados com as proteínas recombinantes sobreviventes possuíam leptospiras em seus fígados. Já todos os animais vacinados com a bacterina e desafiados sobreviveram (Figura 34). Os figados macerados e cultivados mostraram ser negativos quanto a presença de leptospiras (Tabela 5).

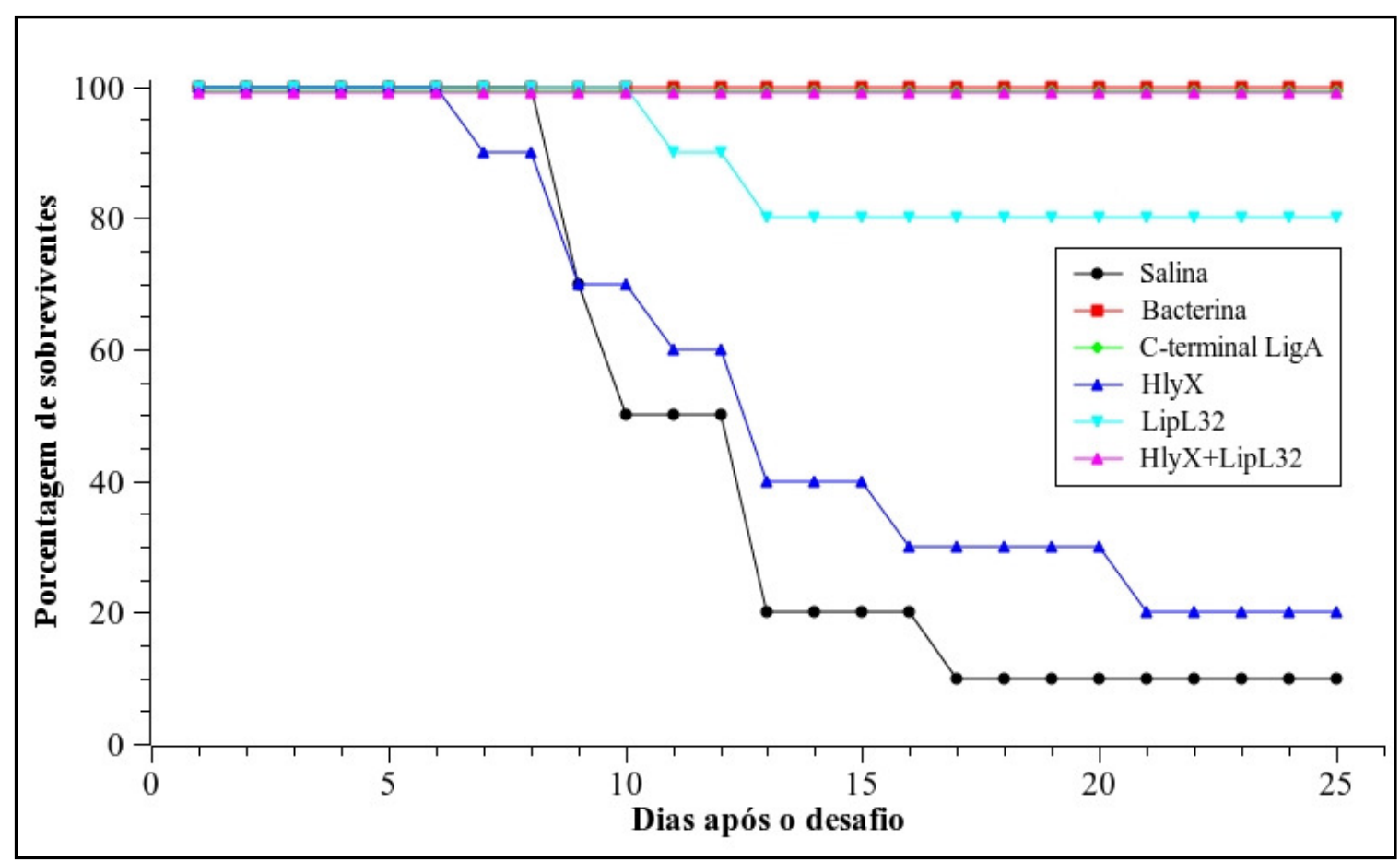

Figura 34 - Análise da porcentagem de sobrevivência dos grupos de animais vacinados: salina, bacterina, C-terminal LigA, HlyX, LipL32 e HlyX co-adminstrada com LipL32, realizada em um período de 28 dias, após desafio com $10^{5}$ Leptospira interrogans sorovar Copenhageni virulentas. 
Tabela 5 - Avaliação do desafio animal quanto ao número de animais sobreviventes e a presença de leptospiras no fígado dos animais vacinados (portadores).

\begin{tabular}{ccccc}
$\begin{array}{c}\text { Grupos } \\
\text { vacinados }\end{array}$ & $\begin{array}{c}\text { Porcentagem } \\
\text { de } \\
\text { sobrevivência }\end{array}$ & Vivos/Total & $\begin{array}{c}\text { Valor de P em } \\
\text { relação ao grupo } \\
\text { salina* }\end{array}$ & $\begin{array}{c}\text { Portadores/Total de } \\
\text { sobreviventes }\end{array}$ \\
\hline $\begin{array}{c}\text { Salina } \\
\text { C-terminal de }\end{array}$ & $10 \%$ & $1 / 10$ & ---- & $1 / 1$ \\
LigA & $100 \%$ & $10 / 10$ & $<0,001$ & $10 / 10$ \\
Bacterina & $100 \%$ & $10 / 10$ & $<0,001$ & $0 / 10$ \\
LipL32 & $80 \%$ & $8 / 10$ & $<0.01$ & $8 / 8$ \\
LipL32 + HlyX & $100 \%$ & $10 / 10$ & $<0,001$ & $10 / 10$ \\
HlyX & $20 \%$ & $2 / 10$ & $>0,05$ & $2 / 2$ \\
\hline
\end{tabular}

* Teste Exato de Fisher 


\section{DISCUSSÃO}

As vacinas existentes contra a leptospirose até o momento são preparadas a partir de suspensões de leptospiras atenuadas ou inativadas, o que pode levar a reações adversas. Além disso, são sorovar específicas, não oferecendo ampla cobertura e longo período de proteção.

Visando contribuir de forma efetiva para o combate à disseminação da leptospirose, escolhemos através do sequenciamento do genoma de L. interrogans sorovar Copenhageni (Nascimento, et al., 2004) e de estudos apresentados na literatura de referência, proteínas com potencial diagnóstico e vacinal. Foram objetos deste estudo as proteínas LipL32 e HlyX.

A proteína LipL32 foi identificada anteriormente ao sequenciamento dos genomas de Leptospira (Ren, et al., 2003; Nascimento, et al., 2004; Bulach, et al., 2006) por Haake e colaboradores (2000). LipL32 é uma lipoproteína de superfície (Cullen, et al.,2005), altamente expressa in vitro e in vivo e encontrada somente em espécies patogênicas de Leptospira (Haake, et al., 2000). O sequenciamento do genoma da espécie de vida livre, $L$. biflexa sorovar Patoc mostrou a ausência de gene ortólogo para LipL32 (Picardeau, et al., 2008), demonstrando desta forma que leptospiras patogênicas necessitam por algum motivo desta proteína. Por todos estes atributos, LipL32 se tornou um importante alvo para o desenvolvimento de testes diagnósticos e vacinais (Flannery, et al., 2001; Guerreiro, et al., 2001; Branger, et al., 2001; Branger, et al., 2005 e Seixas, et al., 2007).

Quanto ao gene que codifica a proteína HlyX identificado durante a anotação do genoma de L. interrogans sorovar Copenhageni, este codifica uma provável hemolisina. Porém, nossos dados (Hauk, et al., 2008) mostraram que a proteína não possui atividade hemolítica conforme relatado por Zhang e colaboradores (2005). HlyX também possui homologia com o gene identificado em L. interrogans sorovar Hardjo, que contém 5 domínios tetratricopeptídeos. Segundo a literatura, os domínios tetraticopeptídeos estão envolvidos em interações proteína-proteína (Lamb, et al., 1995). Desta forma, HlyX poderia ser uma possível adesina (fator de colonização) e, consequentemente, um potencial antígeno vacinal, pois a imunização com esta proteína poderia inibir a colonização do hospedeiro.

No presente estudo, todas as proteínas foram clonadas sem seus respectivos peptídeos sinais. Para os estudos com LipL32 foram utilizadas duas diferentes construções, uma sem e outra com a presença de uma cauda de histidina, respectivamente para estudos estruturais e funcionais. Com o intuito de mapear domínios imunodominantes e funcionais de LipL32, mais três construções obtidas através da clonagem de segmentos de LipL32 foram 
realizadas (N-terminal, intermediário e C-terminal). A amplicação do gene que codifica LipL32 foi realizada com o objetivo de se obter uma proteína compreendendo os aminoácidos dos resíduos 21 a 272. Desta forma, excluiu-se a região hidrofóbica da sequência sinal contendo o consenso lipobox definida por comparação entre sequências conhecidas de lipoproteínas (Haake, 2000). O fragmento N-terminal de LipL32 também foi expresso a partir dos resíduo 21 aa, sem a região hidrofóbica.

Para a realização de estudos com HlyX, grande parte da região de aminoácidos referida como provável sequência sinal (posição 1 a 25 aa) também foi excluída. A proteína resultante contém os aminoácidos compreendidos entre os resíduos 22 a 378.

A remoção da sequência sinal das proteínas LipL32 e HlyX foi realizada para evitar um possível mal direcionamento e/ou processamento das proteínas em E. coli, que poderia acarretar um prejuízo no metabolismo desta bactéria e ausência de expressão destas proteínas.

A expressão das proteínas recombinantes foram realizadas com a cepa de expressão, E. coli BL21 (SI) ou E. coli BL21(DE3) Star [plysS]. Na análise comparativa entre as cepas de expressão foram utilizados critérios como: capacidade de expressar a proteína recombinante, níveis de expressão, escape, solubilidade da proteína recombinante e ainda o agente indutor, no caso destas duas linhagens, $\mathrm{NaCl}$ ou IPTG. A maioria da proteínas recombinantes foram expressas na forma solúvel, excetuando-se HlyX e o fragmento $\mathrm{N}$ terminal de LipL32 que foram expressos em maiores quantidades na forma insolúvel, em corpúsculos de inclusão. Com relação a ausência da solubilidade do fragmento N-terminal de LipL32 esta pode ser explicada através de dados obtidos recentemente por Hoke e colaboradores (2008), que clonaram porções contendo diferentes extensões da LipL32. Os fragmentos expressos (posições 20-106 aa, 20-155 aa e 20-200 aa) por Hoke e colaboradores (2008) são todos solúveis e se sobrepõem parcialmente àqueles por nós estudados, fragmento intermediário (93-184 aa) e C-terminal (185-272 aa). É possível que os aminoácidos responsáveis pela solubilidade de LipL32 se localizem após a sequência N-terminal (posição 21-92 aa), presentes na sequência do fragmento intermediário e C-terminal de LipL32).

A expressão de LipL32 em meio mínimo (M9) sem sal (agente indutor na E. coli BL21 SI), realizada para a expressão de LipL32 Se-M devido à restrição de aminoácidos no meio de cultivo foi mais demorada. Somente $17 \mathrm{~h}$ após a inoculação obteve-se a densidade óptica ideal para a adição dos aminoácido e do agente indutor. A expressão de LipL32 contendo selênio-metionina (Se-M) baseia-se no bloqueio da biossíntese de metioninas pela 
inibição das aspartoquinases em presença de alta concentração de isoleucina, lisina e treonina (Berne, et al., 1999) e foi realizada para a obtenção de cristais que serviram à resolução da estrutura tridimensional da proteína (ver colaboração adiante com o prof. Dr. Shaker Chuck Farah do Departamento de Bioquímica do IQ/USP).

Com exceção da purificação de LipL32 sem a fusão das seis histidinas na porção Nterminal da molécula, que dificultou o processo de purificação desta proteína, as demais proteínas recombinantes foram purificadas eficientemente. Para a purificação da LipL32 para fins cristalográficos foram escolhidas três técnicas cromatográficas: aniônica, catiônica e hidrofóbica. É importante relatar que foi possível observar nas purificações de LipL32, uma massa molecular (baseada na mobilidade eletroforética) diferente da calculada teoricamente. Esta anomalia na mobilidade eletroforética de LipL32, já havia sido observada por Haake e colaboradores (2000). LipL32 possui uma discrepância de aproximadamente 4 kDa entre a massa molecular observada (32 kDa) e sua massa molecular calculada $(27,6 \mathrm{kDa})$ (Haake , et al.,2000). Uma provável explicação para esta anomalia seria a alta porcentagem de resíduos ácidos (34 de 253 aa; 13,4\%) que poderia reduzir a ligação SDS. A proteína de Leptospira LipL41 e a lipoproteína TpN34 de T. Pallidum são dois exemplos de lipoproteínas com altas porcentagens de resíduos ácidos apresentando essas discrepâncias (Shang, et al., 1996; Swancutt, et al., 1989). A explicação baseada na redução da ligação SDS pela alta porcentagem de resíduos ácidos pode ser confirmada através dos resultados obtidos com a purificação dos fragmentos de LipL32, N-terminal, intermediário e C-terminal. O fragmento intermediário foi o único que apresentou anormalidade na mobilidade eletroforética em gel SDS-PAGE. Os demais fragmentos mostraram mobilidade eletroforética compatível com suas massas moleculares teóricas. O fragmento intermediário se comportou da mesma forma que a LipL32 total, mostrando uma discrepância de aproximadamente 4 kDa entre a mobilidade eletroforética observada e sua massa molecular calculada. Ambos os fragmentos N-terminal e C-terminal possuem baixas porcentagens de resíduos ácidos quando comparados ao fragmento intermediário, que possui em sua sequência 7 aspartatos seguidos.

Experimentos de Western blot foram realizados utilizando-se anticorpos gerados contra todas as proteínas purificadas versus as próprias proteínas e também contra extratos de Leptospira. No caso da LipL32, a informação sobre a expressão desta proteína somente por cepas patogênicas, não sendo encontrada na espécie de vida livre (Haake, et al., 2000) já era amplamente conhecida. Porém após o recente sequenciamento do genoma da L. biflexa sabe- 
se que o gene lipL32 está ausente nos dois cromossomos e no plasmídeo desta cepa (Picardeau, et al., 2008). Esta informação aumenta ainda mais o interesse pelo estudo desta proteína, pois ela provavelmente deve ter algum papel na patogenicidade, mantendo-se altamente conservada entre as cepas patogênicas (Guerreiro, et al., 2001). Além disso, trata-se de uma proteína de superfície (Cullen, et al., 2005), ou seja, deve interagir com moléculas do hospedeiro e, ainda, é a proteína mais expressa durante a infecção (Haake, et al., 2000).

Quanto à proteína HlyX, os anticorpos gerados contra a molécula purificada permitiram verificar que ela é expressa somente nas espécies patogênicas. Porém, o fato da expressão de HlyX não ter sido detectada não significa que o gene que codifica esta proteína, esteja ausente do genoma de espécies saprofíticas. De fato, Picardeau e colaboradores, (2008) mostraram que hlyX está presente no genoma da L. biflexa (cepa saprofítica). Com estas informações, surgem questionamentos com relação à condição e mecanismos de modulação de expressão desta proteína pelas espécies patogênicas e a possibilidade de uma expressão em baixos níveis na cepa saprofítica, não detectadas nas condições experimentais adotadas para este estudo através da técnica de Western blot.

Além da confirmação da identidade das proteínas purificadas, foram realizados ensaios de dicroísmo circular para verificar o enovelamento destas para possíveis ensaios funcionais. A proteína LipL32 6xHis apresentou mais enovelamentos de estrutura secundária randômica quando comparada à LipL32 purificada para crescimento de cristais, que apresentou dobramentos $\alpha$-hélice e folha $\beta$-pregueada mais definidos. A pertubação na estrutura secundária de LipL32 6xHis demonstrada pela intensa presença de dobramentos randômicos deve-se provavelmente à sequência de $3,2 \mathrm{kDa}$ fusionada no $\mathrm{N}$-terminal da proteína resultante de uma sequência do vetor de expressão pDEST17 (Invitrogen), contendo as seis histidinas para purificação através de cromatografia de afinidade. Já a proteína HlyX purificada a partir da renaturação de corpúsculos de inclusão apresentou predominância de típicos dobramentos $\alpha$-hélice. O sucesso obtido no processo de renaturação desta proteína deve-se ao fato de $\alpha$-hélices serem mais estáveis que dobramentos folha $\beta$-pregueada.

Para a pesquisa de anticorpos anti-LipL32 e anti-HlyX em soros de pacientes com leptospirose foram utilizados primeiramente anticorpos anti-IgG, pois Flannery e colaboradores (2001) e Guerreiro e colaboradores (2001), detectaram apenas anticorpos IgG dirigidos contra LipL32. Nesses estudos, não foram detectados anticorpos IgM gerados contra 
LipL32 através de ensaios de ELISA (Flannery, et al., 2001) e nem através de immunobloting (Guerreiro, et al., 2001) utilizando-se soros de pacientes, na fase aguda e convalescente da doença.

No que se diz respeito à HlyX foram detectados anticorpos IgG dirigidos contra esta proteína, indicando que ela é apresentada ao sistema imune durante a infecção. Entretanto, não houve reatividade contra esta proteína com soros de pacientes coletados durante a primeira semana (fase aguda) de infecção. Em contraste, LipL32, a lipoproteína de Leptospira mais expressa durante a infecção em mamíferos (Haake, et al., 2000), foi reconhecida por soros de pacientes com leptospirose na fase aguda (primeira semana de infecção) e na fase convalescente (segunda semana de infecção) da doença. Uma resposta mais intensa e específica para IgM em comparação à IgG foi observada, o que contraria a resposta relatada por Flannery e colaboradores (2001) e Guerreiro e colaboradores (2001). Extratos totais de Leptospira foram utilizados nesses casos, o que poderia explicar as diferenças observadas. Com este resultado obtido com LipL32, pretendeu-se caracterizar o domínio imunodominante da proteína. Os resultados mostraram que a reatividade contra o fragmento C-terminal é detectada logo no início do curso da infecção, e que a reatividade contra o fragmento intermediário parece ser mais tardia. O fragmento $\mathrm{N}$-terminal não parece ser imunogênico, provavelmente pela sua localização próxima à membrana, acarretando um provável impedimento estérico de anticorpos nesta região. Nossos dados indicam que LipL32 pode ser usada como um antígeno diagnóstico tanto na fase aguda quanto na fase convalescente da leptospirose. Em adição a isto, nossos resultados identificaram o domínio C-terminal de LipL32 como um alvo imunológico primário, mostrando de forma inédita uma resposta IgM humoral em todos os pacientes testados.

Outro aspecto examinado nesta tese foi a capacidade das proteínas LipL32 e HlyX de interagir com componentes de matriz extracelular (CME). Os mecanismos pelos quais leptospiras patogênicas invadem e colonizam o hospedeiro ainda são pouco entendidos. Durante a invasão, leptospiras interagem com a matriz extracelular ou proteínas plasmáticas (Barbosa, et al., 2006; Choy, et al., 2007; Lin, et al., 2007; Meri, et al., 2005; Merien, et al., 2000; Stevenson, et al., 2007).

Em condições normais, CME não são expostos para bactérias. Patógenos podem ter acesso aos CME após trauma tecidual seguido de injúria mecânica ou química ou ainda como consequência de uma infecção bacteriana, através da atividade de toxinas e enzimas líticas 
(Fink, et al., 2002). Não seria surpreendente se LipL32, considerada a proteina mais expressa durante a infecção, pudesse estabelecer interações com moléculas do hospedeiro, como CME. Para HlyX considerou-se o fato desta proteína possuir domínios tetratricopeptídeos relacionados com interação proteína-proteína, como uma potencial característica para estabelecer interações com CME.

Os resultados obtidos comprovaram nossas suspeitas, pois foi possível verificar uma ligação específica dose-dependente de LipL32 e HlyX a colágeno tipo IV e fibronectina plamática. Ensaios de competição entre o fragmento C-terminal e intermediário de LipL32, mostraram que o fragmento intermediário não participa da ligação à fibronectina plasmática e colágeno tipo IV. Em contrapartida a competição do fragmento C-terminal com LipL32 não deixou dúvidas quanto ao fato de que mediação da ligação às moléculas testadas ocorre predominantemente via fragmento C-terminal. No caso da LipL32 a capacidade de ligação à fibronectina plasmática e colágeno tipo IV é mediada pelo domínio C-terminal da proteína. Concomitantemente à publicação de nossos dados (Hauk, et al., 2008), Hoke e colaboradores (2008) apresentaram dados atribuindo ao domínio C-terminal de LipL32 o papel de se ligar a componentes de matriz extracelular, concordantes, portanto, com nossos resultados. Foram realizados também ensaios para verificar se LipL32 era capaz de inibir a adesão de leptospiras aos componentes de matriz extracelular. Os resultados mostraram que LipL32 não apresentou efeito inibitório (dados não mostrados), e isto pode ser explicado pela provável existência de múltiplas adesinas em Leptosira.

Muitos patógenos ligam-se a domínios específicos de fibronectina, principalmente ao domínio de interação com heparina (Choy, et al., 2007; Fink, et al., 2002). A proteína LipL32 interagiu com os domínios de ligação a heparina (Fragmento de $30 \mathrm{kDa}$ - F30) e gelatina (Fragmento de $45 \mathrm{kDa}$ - F45). Os resultados obtidos com a proteína HlyX demonstraram que esta proteína interage com fibronectina plasmática (provavelmente via domínio F30), bem como com colágeno tipo IV. Para confirmar a ligação das proteínas via estes domínios de fibronectina foram realizados ensaios para verificar a especificidade destas ligações. Nós demonstramos que heparina e gelatina podem inibir a ligação de LipL32 à fibronectina de forma dose-dependente, indicando que os domínios de ligação a heparina (30 kDa) e gelatina (45 kDa) presentes na fibronectina plasmática estão envolvidos nesta interação. Como HlyX mostrou interagir somente com o domínio de ligação à heparina, os experimentos foram realizados de modo a verificar se heparina poderia inibir a ligação de HlyX à fibronectina de forma dose-dependente. Os resultados mostraram que para HlyX somente o domínio de 
ligação a heparina participa desta ligação. Os valores de $K d$ s aparentes encontrados para HlyX foram bem inferiores aos encontrados para LipL32, principalmente no caso da ligação ao colágeno tipo IV. A presença de 5 tetratricopeptídeos (TRPs) na sequência de HlyX pode, eventualmente, mediar a interação desta proteína com as macromoléculas testadas, já que TPRs estão associados a interações proteína-proteína (Lamb, et al., 1995).

Os valores de $K d$ s para a ligação de LipL32 em fibronectina e colágeno tipo IV indicam que esta proteína interage com $\mathrm{CME}$ com avidez de ligação comparáveis com às das adesinas conhecidas de Leptospira como as Ligs (A e B) (Choy, et al., 2007; Lin, et al., 2007). Entretando, o mesmo não pode ser afirmado para HlyX, pois esta proteína possui avidez de ligação a colágeno tipo IV e fibronectina superior às adesinas de Leptospira mencionadas. Como já mencionado, LipL32 não foi capaz de inibir a adesão de leptospiras à proteínas de matriz extracelular. Ensaios realizados in vitro indicaram que o soro anti-LipL32 falhou no bloqueio da adesão de leptospiras em CME (Hoke, et al., 2008). A ausência de um efeito inibitório observado em ambos os casos poderia ser explicado em parte pela existência de proteínas adicionais de L. interrogans que contribuem para a aderência das leptospiras em CME. Os experimentos de inibição da ligação de leptospiras em CME realizados com LipL32 ainda serão realizados com a proteína HlyX.

O significado biológico da ligação de LipL32 e HlyX à componentes de matriz extracelular ainda não está claro. Existem multiplas isoformas de fibronectina. Fibronectina plasmática, a isoforma que interage com LipL32 e HlyX, é solúvel e circula no sangue e em demais fluídos corporais, participando da formação de coágulos de sangue, cicatrização e na fagocitose. Recentemente, Cinco e colaboradores (2002) demonstraram que leptospiras são capazes de reconhecer e se ligar a integrinas CR3 (MAC-1) expressas em neutrófilos e em células CHO transfectadas com mac-1 (Cinco, et al., 2002). Esta interação parece ocorrer através do domínio I da integrina CR3, que é responsável pelo reconhecimento de iC3b (fragmento do complemento, que se liga às superfícies dos patógenos durante a resposta imune), ICAM-1 (molécula de adesão intercelular da superfamília das imunoglobulinas, expressa no endotélio), fibrinógeno e fibronectina.

De acordo com estes resultados, a adesão das células aumenta quando leptospiras ou as células são pré-tratadas com fibronectina, sugerindo que esta molécula possa facilitar e melhorar a interação entre microrganismos e o domínio I da integrina CR3 (Cinco, et al., 2002). Além das proteínas LipL32 e HlyX, poucas proteínas de Leptospira tem sido mostradas por ligar-se a fibronectina plasmática como por exemplo, uma proteína de $36 \mathrm{kDa}$ 
não caracterizada ligante de fibronectina (Merien, et al., 2000), as proteínas LigA e LigB (Choy, et al., 2007; Lin, et al., 2007), e proteínas de membrana externa tipo endostatina de Leptospira (Len) (Stevenson, et al., 2007). Diversas proteínas presentes em outros microrganismos patogênicos se ligam à fibronectina (Joh, et al., 1999). Glicoproteínas adesivas, assim como fibronectina ou laminina, tem sido definidas como domínios de ligação de células e bactérias, enquanto colágeno fornece múltiplos sítios de interação para células e patógenos ao longo da estrutura de tripla hélice, mostrando-se desta forma como uma importante molécula participa de forma dinâmica nestes tipos de interações (Preissner e Chhatwal, 2005). Além do mais, colágenos frequentemente formam agregados supramoleculares que variam na estrutura e na composição, dependendo da associação com outras moléculas da CME como fibronectina, vitronectina, fator de von Willebrand, laminina, nidogenio e proteoglicanos. Em muitos casos, as interações com bactérias não é determinada exclusivamente pelo componente colágeno (Preissner e Chhatwal., 2005).

LipL32 e HlyX exibiram uma ligação significante a colágeno tipo IV, que é o maior componente de membranas. Sobre a injúria tecidual, particularmente nos sítios de cicatrização ou degradação de CME, esta molécula vem a ser exposta e a interação com proteínas da superfície de bactérias pode ocorrer. A presença de multiplos sítios de ligação a CME em uma única proteína pode ser de grande importância (Cameron, et al., 2004). As proteínas de Leptospira LigA, LigB e Len mostraram a habilidade de se ligar em vários CMEs (Choy, et al., 2007; Stevenson, et al., 2007), assim como a proteína autotransportadora, Hap de Haemophilus influenzae (Fink, et al., 2002). Leptospiras circulantes ligadas a fibronectina plasmática poderiam atingir diferentes alvos teciduais. De fato, foi demonstrado que a fibronectina plasmática melhora a aderência de Streptococcus sanguis em gelatina (Lowrance, et al.,1988). É possível que fibronectina ligada a LipL32 ou HlyX também ajude nesta interação com colágeno tipo IV presente nos componentes de matriz do endotélio.

Portanto, os resultados relacionados a interação de LipL32 e HlyX à fibronectina plasmática e colágeno IV obtidos nesta tese, nos permite sugerir que as proteínas de Leptospira abordadas neste estudo participam da patogênese da leptospirose, apesar de não estar muito claro por qual mecanismo estas proteínas se associam à colágeno tipo IV e fibronectina plasmática para atuar no hospedeiro.

A maioria dos estudos realizados com proteínas de Leptospira têm como principal objetivo a descoberta de antígenos para diagnóstico ou vacinas. Baseados nos estudos de 
vacinologia reversa (Rappuoli e Covacci, 2003), genomas de diferentes sorovares e espécies de Leptospira foram sequenciados e vários genes identificados. Os esforços se concentram na busca por um antígeno que confira proteção contra todas as espécies e sorovares de Leptospira. Entre os antígenos testados que conferiram proteção parcial contra Leptospira interrogans em modelo de desafio animal encontram-se OmpL1 co-adminstrada com LipL41 (Haake, et al., 1999), o fragmento C-terminal da proteína LigA (Palaniappan, et al., 2006; Silva, et al., 2007), a proteína LipL32 em diferentes formas de apresentação: adenovírus (Branger, et al., 2001), vacina de DNA e LipL32 recombinante associada a hidróxido de alumínio (Branger, et al., 2005) e Mycobacterium bovis (BCG) (Seixas, et al., 2007). Ainda não existe um entendimento detalhado do mecanismo de imunidade do hospedeiro para Leptospira. É observado que a aquisição da imunidade que protege contra a re-infecção por Leptospira ocorre naturalmente e assume-se que esta imunidade seja humoral (Bharti, et al., 2003). Esta imunidade protetora pode ser atribuída pelo anticorpos gerados contra lipopolissacarídeos específicos de cada sorovar. Lipopolissacarídeos de Leptospira estimulam o sistema de resposta inata via um mecanismo dependente de TLR2, um mecanismo potencial adicional tanto de imunidade protetora como de imunopatogênese (Werts, et al., 2001).

O papel da imunidade celular em leptospirose está sendo explorado. Estudos realizados com gado imunizado com uma vacina composta por L. borgpetersenii mortas mostrou in vitro uma resposta de proliferação de células $\mathrm{T} C \mathrm{CD} 4+$ e células $\mathrm{T} \gamma \delta$ e ainda a produção de interferon $\gamma$ após estimulação realizada com uma preparação contendo Leptospira (Naimam, et al., 2001).

Nos nossos estudos de atividade vacinal (protetora), a proteína HlyX foi o principal objeto de pesquisa, pelo fato de ainda não ter sido estudada com este propósito. Portanto era importante explorar esta possível atividade, já que HlyX é reconhecida pelo sistema imune e ainda possui a habilidade de interagir com proteínas do hospedeiro. Portanto, para estes fins foram realizados estudos com HlyX, LipL32 e HlyX em co-administração com LipL32 em modelo de desafio animal (hamsters), utilizando-se hidróxido de alumínio como adjuvante.

O fragmento C-terminal de LigA foi incorporado ao experimento como um controle positivo de proteína recombinante que apresenta atividade protetora (Palaniappan, et al., 2006; Silva, et al., 2007). Entretanto, deve-se destacar que o fragmento de LigA (posição resíduos de aa 817-1224 aa) utilizado nos nossos ensaios de imunização não corresponde exatamente à sequência de aminoácidos dos fragmentos utilizados nos estudos de imunização e desafio animal realizados por Palaniappan e colaboradores (2006) e Silva e colaboradores 
(2007). Além do fragmento C-terminal de LigA, também utilizou-se uma bacterina preparada a partir de células da mesma cepa virulenta utilizada no desafio animal, como controle positivo.

$\mathrm{Na}$ avaliação da capacidade das proteínas recombinantes HlyX, LipL32 e fragmento C-terminal de LigA de induzir a produção de anticorpos IgG dirigidos contra as mesmas, através da imunização pela via subcutânea pode-se constatar que HlyX mostrou-se altamente imunogênica pelo alto título de anticorpos IgG apresentados (1:128.000), assim como o fragmento C-terminal de LigA (1:64.000). A proteína LipL32 mostrou também ser capaz de induzir a produção de anticorpos IgG, mas em quantidades menores (1:16.000) quando comparada com as duas outras proteínas recombinantes estudadas.

A alta imunogenicidade de HlyX, representada através dos altos títulos de anticorpos gerados pode se atribuida pela baixíssima similaridade que esta proteína tem com as proteínas do hospedeiro. Interessantemente, o fragmento $\mathrm{C}$-terminal de LigA mostrou reatividade cruzada contra os soros de animais imunizados com LipL32. O contrário também foi observado, a proteína LipL32 mostrou a mesma reatividade cruzada contra os soros de animais imunizados contra o fragmento C-terminal de LigA.

Com relação a estes resultados, poucas suposições podem ser levantadas já que seriam necessários mais experimentos para comprovar se este tipo de resposta é persistente com os dados observados. É possível que no processo de purificação tenha havido algum tipo de contaminação proveniente de E. coli e que esta houvesse se mantido em ambas as purificações de LipL32 e do fragmento C-terminal de LigA. Apesar do fato das expressões terem sido realizadas em diferentes cepas de expressão, e do fato das proteínas terem sido expressas em diferentes formas: LipL32 na forma solúvel e purificada a partir do sobrenadante do lisado bacteriano e o fragmento C-terminal de LigA expresso na forma insolúvel e purificado após renaturação, existe a possibilidade de alguma(s) proteína(s) presente em ambas as cepas de $E$. coli ter sido co-purificada com as proteínas recombinantes, e em baixas concentrações, a ponto de não ser visualizada em gel corado com Comassie blue. A possibilidade de LipL32 e o fragmento C-terminal de LigA possuírem algum tipo de similaridade na sequência de aminoácidos está descartada. Intrigantemente, não foram detectados títulos de anticorpos IgG dirigidos contra LipL32 nos soros de animais imunizados com bacterina. Sendo LipL32 a proteína de superfície mais expressa durante a infecção (Cullen, et al., 2005; Haake, et al., 2000), era esperada a detecção de títulos de anticorpos gerados contra esta proteína nos animais imunizados com esta preparação. Apesar dos altos títulos de anticorpos gerados pela 
proteína HlyX esta obteve praticamente o mesmo desempenho do controle negativo (salina) ou seja, não apresentou capacidadade protetora em modelo de desafio animal, no esquema de imunização utilizado. Os anticorpos $\operatorname{IgG}$ gerados contra HlyX utilizando hidróxido de alumínio como adjuvante não foram capazes de neutralizar o patógeno de forma eficiente. É portanto, possível que HlyX isoladamente não seja um bom candidato vacinal.

Apenas as preparações de LipL32, HlyX em co-administração com LipL32 e os controles positivos, fragmento C-terminal de LigA e bacterina conferiram proteção. No caso da proteção conferida pela co-administração de LipL32 e HlyX, pode-se atribuir a proteção principalmente à proteína LipL32 e não à proteína HlyX, pois LipL32 conferiu 80\% de proteção quando administrada individualmente. Entretanto esta proteção, não foi esterelizante já que todos os fígados dos animais sobreviventes apresentavam leptospiras. Uma proteção parcial $(50 \%)$ conferida por LipL32 recombinante utilizando hidróxido de alúminio e saponina como adjuvantes também foi observada por Branger e colaboradores (2005).

O fragmento C-terminal de LigA conferiu $100 \%$ de proteção, embora não tenha sido esterilizante, conforme os resultados descritos na literatura (Palaniappan, et al., 2006; Silva, et al., 2007) já que os animais continuavam sendo portadores de leptospiras. Entretanto, a comparação dos nossos resultados obtidos com animais imunizados com o fragmento Cterminal de LigA não podem ser comparados aos dados descritos na literatura, pois o fragmento de LigA de Palaniappan e colaboradores (2006) e de Silva e colaboradores (2007) diferem em número de aminoácidos do fragmento utilizado pelo nosso grupo na imunização dos animais.

A bacterina mostrou ser a preparação vacinal mais eficaz, pois além da proteção total apresentou atividade esterelizante, já que nenhum dos animais sobreviventes era portador de leptospiras. Apesar de eficaz, a bacterina é sorovar específica, portanto não oferece cobertura em relacão aos sorovares (mais de 200 sorovares) que não estão presentes na preparação vacinal. Além do mais, a proteção conferida por este tipo de preparação não é duradora, sendo necessária a vacinação frequente para a manutenção da imunidade humoral (Levett, 2001). Para imunizações em humanos, este tipo de medida profilática torna-se um problema ainda maior, pois existem muitas reações adversas neste tipo de preparação, provocadas pelos lisados celulares e pelo próprio meio de cultura. Portanto esta estratégia de vacinação com bacterina deve ser descartada e os esforços em busca de uma vacina contra a leptospirose continuada. 
Apesar dos resultados obtidos no modelo de desafio animal serem um indicativo da atividade vacinal de LipL32, serão necessários mais ensaios de desafio para a comprovação dos resultados.

Os resultados obtidos com as proteínas LipL32 e HlyX nos levam a concluir que estas proteínas podem ter realmente um papel relacionado com a patogênese da leptospirose. Com relação a HlyX, serão necessários mais estudos visando avaliar a função desta proteína que, além de ser expressa em cepas patogênicas, e ser reconhecida pelo sistema imune, possui a capacidade de interagir com proteínas do hospedeiro, e é altamente imunogênica.

A proteína LipL32 vem sendo mais estudada pelo fato de estar presente somente em cepas patogênicas de Leptospira e por ser altamente expressa tanto em cultura como no hospedeiro. Muitos trabalhos especulam o potencial diagnóstico e vacinal de LipL32, bem como seu papel na patogênese. Estudos mostraram que LipL32 é reconhecida pelo sistema imune do hospedeiro, apresentando-se desta forma como um potencial antígeno vacinal e diagnóstico e, ainda, foi demonstrado que ela interage com proteínas do hospedeiro. Por todos estes motivos, esta proteína desperta a curiosidade de toda a comunidade científica que trabalha na área.

Curiosamente, um estudo genético realizado por Murray e colaboradores (2008) mostrou que hamsters inoculados com leptospiras mutantes para LipL32 apresentaram manifestações clínicas (doença grave) exibidas pelo grupo controle (hamsters inoculados com leptospiras selvagens). Porém este resultado ainda não deve ser considerado definitivo para afirmar que LipL32 não possui relevância na patogênese. Aliás, este resultado parece ser tão antagônico quanto àqueles obtidos com a proteína LoA22 (OmpA) por Ristow e colaboradores (2007). O gene que codifica para esta proteína é encontrado tanto no genoma de leptospiras patogênicas como no de leptospiras de vida livre (Picardeau, et al., 2008). LoA22 parece ser uma proteína crucial para a virulência da Leptospira (Ristow, et al., 2007). Entretanto, se LoA22 é tão importante para a virulência da Leptospira, qual seria o motivo de L. biflexa, a cepa saprofítica, trazer em seu genoma o gene que codifica essa proteína e não possuir o gene que codifica a LipL32? Qual seria o papel biológico de uma proteína expressa em altos níveis por uma bactéria patogênica, sem que aquela tenha um papel fundamental para a sobrevivência desta bactéria?

Estudos relacionados à resolução da estrutura tridimensional de LipL32 podem ajudar a desvendar o verdadeiro papel desta proteína na patogênese da Leptospira. Embora não apresentada nesta tese, a estrutura tridimensional de LipL32 foi resolvida em colaboração com 
o Prof. Dr. Shaker Chuck Farah do Departamento de Bioquímica do Instituto de Química da USP. A estrutura de LipL32 (ver Anexo) número de depósito no PDB, Protein Data Bank : 3FRL) possui uma topologia jell-roll (rocambole) e mostrou que esta possui similaridades topológicas com duas outras proteínas que se ligam a cálcio, como calpaína-7 e colagenase. Estudos de dicroísmo circular e fluorescência realizados com LipL32 na presença e na ausência de cálcio, comprovaram os indícios da ligação a cálcio obtidos através da comparação realizada entre as topologias das proteínas presentes nos bancos de dados. Um artigo científico abordando os dados obtidos com a resolução da estrutura tridimensional de LipL32 e a ligação a cálcio foi recentemente submetido para a publicação (Anexo).

Sabe-se que o hospedeiro possui altas concentrações de cálcio e que microrganismos requerem este íon para muitas das suas funções biológicas como transdução de sinal, controle da divisão e ciclo celular, competência, patogênese, motilidade e quimiotaxia, interações patógeno-hospedeiro, estabilidade e manutenção da integridade da membrana externa lipopolissacarídica e da parede celular, atividade e estabilização de várias enzimas e proteínas, muitas delas localizadas extracelularmente e controladas por ligação a $\mathrm{Ca}^{2+}$ (Lin, et al., 2008).

Os estudos realizado por Johnson e Gary (1963) e Shenberg (1967) demostraram a importância dos íons cálcio para a sobrevivência e o crescimento de Leptospira sp. Recentemente, LigB, uma importante proteína da família de proteínas de Leptospira que possuem domínios tipo imunoglobulina bacteriano (BIg) também encontrado na LigA, mostrou se ligar a íons cálcio (Lin, et al., 2008). Assim como LipL32, LigA e LigB interagem com componentes de matriz extracelular, fibronectina, fibrinogenio, laminina e colágeno (Choy, et al., 2007; Lin, et al., 2007; Lin e Chang, 2008).

Conjuntamente todos os resultados obtidos demonstram uma alta complexidade de interações entre LipL32 e diversos ligantes como proteínas da matriz extracelular e íons cálcio. Desta forma, futuros estudos de mutação sítio dirigida e co-cristalização de LipL32 com possíveis receptores podem ajudar a desvendar o papel de LipL32 na patogênese. 


\section{CONCLUSÕES}

1- A proteína HlyX, bem como LipL32 6xHis e seus fragmentos, N-terminal, intermediários e C-terminal podem ser expressos utilizando E. coli, como sistema de expressão heterólogo.

2- A proteína HlyX, expressa em sua maior parte em forma de corpúsculos de inclusão, pode ser renaturada por diluição, sendo este resultado confirmado por dicroísmo circular.

3- HlyX, LipL32 6xHis e seus fragmentos foram purificadas eficientemente, utilizando-se cromatografia de afinidade $\mathrm{Ni}^{2+}$.

4- LipL32 obteve grau de pureza suficiente para ensaios de cristalização, através das cromatografias aniônica, catiônica e hidrofóbica.

5- HlyX mostrou ser uma proteína expressa somente em cepas de Leptospira patogênicas, embora a possibidade desta proteína ser expressa em baixos níveis na cepa saprofítica e não ser detectada devido as condições experimentais empregadas, não estar descartada.

6- LipL32 é uma proteína expressa somente em cepas de Leptospira patogênicas como ampalmente dilvulgado na literatura.

7- Foram encontrados em soros de pacientes com leptospirose confirmada, anticorpos IgG dirigidos contra HlyX somente na fase crônica da infecção por leptospiras, não havendo a produção de anticorpos IgM contra esta proteína em nenhuma dos soros dos pacientes com leptospirose que foram testados.

8- LipL32 mostrou induzir anticorpos $\operatorname{IgM}$ e $\operatorname{IgG}$ durante a infecção por leptospiras em pacientes com leptospirose confirmada.

9- O fragmento C-terminal (resíduos 185-272 aa) de LipL32 mostrou ser o domínio imunodominante, embora o fragmento intermediário (resíduos 93-184 aa) também seja reconhecido pelo sistema imune do hospedeiro em uma fase mais tardia da infecção, 
diferentemente do fragmento $\mathrm{N}$-terminal (resíduos 21-92 aa) que não mostrou nenhuma reatividade em qualquer fase da infecção.

10- Ambas as proteínas HlyX e LipL32 ligam-se a fibronectina plasmática e colágeno tipo IV, sendo a avidez da ligação de HlyX nestas proteínas maior do que a encontrada para LipL32. 11- A ligação de LipL32 e HlyX a fibronectina plasmática ocorrem ambas no domínio de ligação a heparina $(30 \mathrm{kDa})$. No caso de LipL32, a ligação a fibronectina plasmática também ocorre devido a interação ao domínio de ligação a gelatina (45kDa).

12- No caso de LipL32 a ligação desta às proteínas, fibronectina plasmática e colágeno tipo IV são mediadas pelo fragmento C-terminal (resíduos 185-272 aa), sendo que os outros dois domínios não participam destas interações.

13- A proteína HlyX não demonstrou atividade protetora segundo o ensaio de imunização e desafio animal utilizados neste estudo, mas em contrapartida apresentou-se altamente imunogênica pelos títulos de anticorpos IgG gerados em hamsters.

14- LipL32 e a co-administração HlyX com LipL32 mostraram atividade protetora, sendo LipL32 a proteína protetora na co-administração. 


\section{REFERÊNCIAS BIBLIOGRÁFICAS ${ }^{*}$}

Arean VM. The pathologic anatomy and pathogenesis of fatal human leptospirosis (Weil's Disease). American Journal of Pathology. 1962;40:393-415.

Bajani MD, Ashford DA, Bragg SL, Woods CW, Aye T, Spiegel RA, Plikaytis BD, Perkins, BA, Phelan M, Levett PN, Weyant RS. Evaluation of four comercially available rapid serologic tests for diagnosis of leptospirosis. Journal of Clinical Microbiology. 2003;41:80309

Barbosa AS, Abreu PAE, Neves FO, Atzingen MV, Watanabe MM, Vieira ML, Morais ZM, Vasconcellos AS, Nascimento, ALTO. A newly identified leptospiral adhesin mediates attachment to laminin. Infection and Immunity. 2006;74:6356-64.

Beuken E, Vink C, Bruggeman CA. One-step procedure for screening recombinant plasmids by size. Biotechniques. 1998;24(5):748-50.

Berne PF, Doublié S, Carter CWJ. Crystallization of nucleic acids and proteins: A practical approach. $2^{\text {nd }}$ ed. Oxford University Press; 1999.

Bhandari P, Gowrishankar J. An Escherichia coli host strain useful for efficient overproduction of cloned gene products with $\mathrm{NaCl}$ as the inducer. Journal of Bacteriology. 1997;179:4403-06.

Bharti AR, Nally JE, Ricaldi JN, Matthias MA, Diaz MM, Lovett MA, Levett PN, Gilman R H, Willig MR, Gotuzzo E, Vinetz JM. On behalf of the Peru-United States Leptospirosis Consortium. Leptospirosis: a zoonotic disease of global importance. Lancet Infection Diseases. 2003;3:757-71.

Branger C, Chatrenet B, Gauvrit A, Aviat F, Aubert A, Bach JM, Andre-Fontaine G. Protection against Leptospira interrogans sensu lato challenge by DNA immunization with the gene encoding hemolysin-associated protein 1. Infection and Immunity. 2005;73:4062-69.

Branger C, Sonrier C, Chatrenet B, Klonjkowski B, Ruvoen-Clouet N, Aubert A, Andre'Fontaine G, Eloit M. Identification of the hemolysis-associated protein 1 as a cross-protective immunogen of Leptospira interrogans by adenovirus-mediated vaccination, Infection and Immunity. 2001;69:6831-38.

Brenner DJ, Kaufmann AF, Sulzer KR, Steigerwalt AG, Rogers FC, Weyant RS, Further determination of DNA relatedness between serogroups and serovars in the family Leptospiraceae with a proposal for Leptospira alexanderi sp. nov. and four new Leptospira genomospecies. International Journal of Systematic Bacteriology. 1999;49:839-58.

\footnotetext{
*De acordo com:

International Committee of Medical Journal Editors. Uniform requirements for manuscripts submitted to Biomedical Journal: sample references. Available from: http://www.icmje.org [2007 May 22].
} 
Bulach DM, Zuerner RL, Wilson P, Seemann T, McGrath A, Cullen PA, Davis J, Johnson M, Kuczek E, Alt DP, Peterson-Burch B, Coppel RL, Rood JI, Davies JK, Adler B. Genome reduction in Leptospira borgpetersenii reflects limited transmission potential. Proceeding of National Academy Sciences of the United States of America. 2006;103:14560-65.

Burth P, Younes-Ibrahim M, Gonecalez FH, Costa ER, Faria MV, Purification and characterization of a Na+, $\mathrm{K}+$ ATPase inhibitor found in an endotoxin of Leptospira interrogans. Infection and Immunity. 1997;65:1557-60.

Caldas EM, Costa E, Sampaio MB, Leptospirosis in Salvador (Brazil). Clinical and laboratory aspects. Revista do Instituto de Medicina Tropical de São Paulo. 1978;20:164-76.

Cameron CE, Brown EL, Kuroiwa JM, Schnapp LM, Brouwer NL, Treponema pallidum fibronectin-binding proteins. Journal of Bacteriology. 2004;186:7019-22.

Cameron CE, Identification of a Treponema pallidum laminin-binding protein. Infection and Immunity. 2003;71:2525-33.

Charon WN, Goldestein FS, Genetics of Motility and Chemotaxis of a Fascinating Group of Bacteria: The Spirochetes. Annual Review of Genetics. 2002;36:47-73.

Choy HA, Kelley MM, Chen TL, Møller AK, Matsunaga J, Haake DA, Physiological osmotic induction of Leptospira interrogans adhesion: LigA and LigB bind extracellular matrix proteins and fibrinogen. Infection and Immunity. 2007;75:2441-50.

Cinco M, Cini B, Perticarari S, Presani G, Leptospira interrogans binds to CR3 receptor on mammalian cells. Microbial Pathogenesis. 2002;33:299-305.

Cullen PA, Xu X, Matsunaga J, Sanchez Y, Ko AI, Haake, DA, Adler B. Surfaceome of Leptospira spp. Infection and Immunity. 2005;73:4853-63.

Cullen PA, Haake DA, Bulach DM, Zuerner RL, Adler B. LipL21 is a novel surface-exposed lipoprotein of pathogenic Leptospira species. Infection and Immunity. 2003,71:2414-21.

Dahle UR, Tronstad L, Olsen I, 3-Hydroxy fatty acids in a lipopolysaccharide-like material from Treponema denticola strain FM. Endodontics \& dental traumatology. 1996;12:202-05.

Dey S, Mohan CM, Kumar TM, Ramadass P, Nainar AM, Nachimuthu K. Recombinant LipL32 antigen-based single serum dilution ELISA for detection of canine leptospirosis. Veterinary Microbiology. 2004;103:99-106.

Duong F, Eichler J, Price A, Leonard MR, Winckner W. Biogenisis of the gram-negative bacterial envelope. Cell. 1997;91:567-73.

Everard CO, Edwards CN, Everard JD, Carrington DG. A twelve-year study of leptospirosis on Barbados. European Journal of Epidemiology. 1995;11:311-20.

Faine S. Guidelines for the Control of Leptospirosis. Geneva: World Health Organization; 1982. 
Faine S, Adler B, Bolin C, Perolat P. Leptospira and Leptospirosis. $2^{\text {nd }}$ ed. Melbourne: MediSci; 1999.

Fink DL, Green BA, Geme III JW St. The Haemophilus influenza Hap autotransporter binds to fibronectin, laminin, and collagen IV. Infection and Immunity. 2002;70:4902-07.

Flannery B, Costa D, Carvalho FP, Guerreiro H, Matsunaga J, da Silva ED, Ferreira AG, Riley LW, Reis MG, Haake DA, Ko AI. Evaluation of recombinant Leptospira antigen-based enzyme-linked immunosorbent assays for the serodiagnosis of leptospirosis. Journal of Clinical Microbiology. 2001;39:3303-10.

Fraser CM, Casjens S, Huang WM, Sutton GG, Clayton R, Lathigra R, White 0, Ketchum KA, Dodson R, Hickey EK, Gwinn M, Dougherty B, Tomb JF, Fleischmann RD, Richardson D, Peterson J, Kerlavage AR, Quackenbush J, Salzberg S, Hanson M, van Vugt R, Palmer N, Adams MD, Gocayne J, Venter JC. Genomic sequence of a Lyme disease spirochaete, Borrelia burgdorferi. Nature. 1997;390:580-6.

Fraser CM, Norris SJ, Weinstock GM, White 0, Sutton GG, Dodson R, Gwinn M, Hickey EK, Clayton R, Ketchum KA, Sodergren E, Hardham JM, McLeod MP, Salzberg S, Peterson J, Khalak H, Richardson D, Howell JK, Chidambaram M, Utterback T, McDonald L, Artiach P, Bowman C, Cotton MD, Venter JC. Complete genome sequence of Treponema pallidum, the syphilis spirochete. Science. 1998;281:375-88.

Gamberini M, Gómez RM, Atzingen MV, Martins EAL, Vasconcellos SA, Romero EC, Leite LCC, Ho PL, Nascimento ALTO. Whole-genome analysis of Leptospira interrogans to identify potential vaccine candidates against leptospirosis. FEMS Microbiology Letters. 2005; 244:305-13.

Goldstein SF, Charon NW, Motility of the spirochete Leptospira. Cell. Motility and Cytoskeleton. 1988;9:101-10.

Guerreiro H, Croda J, Flannery B, Mazel M, Matsunaga J, Reis MG, Levett PN, Ko AI, Haake DA. Leptospiral proteins recognized during the humoral immune response to leptospirosis in humans. Infection and Immunity. 2001;69:4958-68.

Haake DA, Mazel MK, McCoy AM, Milward F, Chao G, Matsunaga J, Wagar EA. Leptospiral outer membrane proteins OmpL1 e LipL41 exhibit synergistic immunoprotection. Infection and Immunity. 1999;67:6572-82.

Haake DA. Spirochaetal lipoproteins and pathogenesis. Microbiology. 2000;146:1491-504.

Haake DA, Chao G, Zuerner RL, Barnett JK, Barnett D, Mazel M, Matsunaga J, Levett PN, Bolin CA. The leptospiral major outer membrane protein LipL32 is a lipoprotein expressed during mammalian infection. Infection and Immunity. 2000;68:2276-85.

Habicht GS, Beck G, Benach JL, Coleman JL, Borrelia burgdorferi lipopolysaccharide and its role in the pathogenesis of Lyme disease. Zentralblatt fuer Bakterlologie, Mikrobiologie und hygiene (reihe A). 1986;263:137-41.

Hauk P, Macedo Felipe, Romero EC, Vasconcellos AS, de Morais ZM, Barbosa AS, Ho P L. In LipL32, the Major Leptospiral Lipoprotein, the $\mathrm{C}$ Terminus Is the Primary 
Immunogenic Domain and Mediates Interaction with Collagen IV and Plasma Fibronectin. Infection and Immunity. 2008;76:2642-50.

Hauk P, Negrotto S, Romero CE, Vasconcellos SA, Genovez EC, Ward RJ, Schattner M, Gómez RM, Ho PL. Expression and characterization of hemolysin from Leptospira interrogans serovar Copenhageni: Potentiation of hemolytic activity by LipL32. Biochemical and Biophysical Research Communications. 2005;333:1341-47.

Hauk P, Negrotto S, Romero CE, Vasconcellos SA, Genovez EC, Ward RJ, Schattner M, Gómez RM, Ho PL. Expression and characterization of hemolysin from Leptospira interrogans serovar Copenhageni: Potentiation of hemolytic activity by LipL32. 2008;372:948. Corrigendum in: Hauk P, Negrotto S, Romero CE, Vasconcellos SA, Genovez EC, Ward RJ, Schattner M, Gómez RM, Ho PL. Biochemical and Biophysical Research Communications. 2005;333:1341-47.

Hayashi S, Wu HC. Lipoproteins in bacteria. Journal of Bioenergetics and Biomembranes. 1990;22:451-71.

Heinemann MB, Garcia JF, Nunes CM, Gregori F, Higa ZMM, Vasconcellos AS, Richtzenhain LJ. Detection and differentiation of Leptospira spp. serovars in bovine semen by polymerase chain reaction and restriction fragment length polymorphism. Veterinary Microbiology. 2000;73:261-7.

Hengge UR, Tannapfel A, Tyring SK, Erbel R, Arendt G, Ruzicka T. Lyme borreliosis. The Lancet Infectious Diseases. 2003,3:489-500.

Hoke DE, Egan S, Cullen PA, Adler B. LipL32 is an extracellular-matrix-interacting protein of Leptospira and Pseudoalteromonas tunicata. Infection and Immunity. 2008;76:2063-9.

Ikoev VN, Gorbunov MA, Vachaev BF, Iagovkin EA, Kondratenko VF, Anan'ina IuV, Ansimova TI, Kostina NI, Iur'eva IL, Nikitin MG. The evaluation of the reactogenicity and immunogenic activity of a new concentrated inactivated leptospirosis vaccine. Zhurnal Mikrobiologii, Epidemiologii I Immunobiologii. 1999;4:39-43.

Joh D, Wann ER. Kreikemeyer B, Speziale P, Höök, M. Role of fibronectin-binding MSCRAMMs in bacterial adherence and entry into mammalian cells. Matrix Biology. 1999;18:211-23.

Johnson CR. The Spirochetes. Annual Reviews Microbiology. 1977;31:89-106.

Johnson RC, Gary ND. Nutrition of Leptospira Pomona. Calcium, Magnesium, and Potassium Requirements. Journal of Bacteriology. 1963; 85: 983-5.

Ko AI, Galvão Reis M, Ribeirodourado CM, Johnson WD, Riley LW. Urban epidemic of severe leptospirosis in Brazil. Salvador Leptospirosis Study Group. Lancet. 1999;354:820-5.

Kuriakose M, Eapen CK, Paul R. Leptospirosis in Kolenchery, Kerala, India: epidemiology, prevalent local serogroups and serovars and a new serovar. European Journal of Epidemiology. 1997;13:691-7.

Laemmli UK. Cleavage of structural proteins during assembly of head of bacteriophage T4. Nature. 1970;227:680-5. 
Lamb JR, Tugendreich S, Hieter P. Tetratrico peptide repeat interactions: to TPR or not to TPR? Trends in Biochemical Sciences. 1995;20:257-9.

Lecour H, Miranda M, Magro C, Rocha A, Gonçalves V. Human leptospirosis- a review of 50 cases. Infection. 1989;17:8-12.

Levett PN. Leptospirosis. Clinical Microbiology Reviews. 2001;14:296-326.

Levett PN. Usefulness of serologic analysis as a predictor of the infecting serovar in patients with severe leptospirosis. Clinical Infectious Diseases. 2003;36:447-52.

Lin YP, Chang YF. A domain of the Leptospira LigB contributes to high affinity binding of fibronectin. Biochemical and Biophysical Research Communications. 2007;362:443-48.

Lin YP, Chang YF. The C-terminal variable domain of LigB from Leptospira mediates binding to fibronectin. Journal of Veterinary Science. 2008;9:133-44.

Lin YP, Raman R, Sharma Y, Chang YF. Calcium binds to leptospiral immunoglobulin-like protein, LigB, and modulates fibronectin binding. Journal of Biology Chemistry. 2008;283:25140-9.

Lowrance JH, Hasty DL, Simpson WA. Adherence of Streptococcus sanguis to conformationally specific determinants in fibronectin. Infection and Immunity. 1988;56:2279-85.

Martínez-Sánchez R, Obregón Fuentes AM, Pérez S, A. Baly Gil A, Díaz González M, Baró Suárez M, Menéndez Capote R, Ruiz Pérez A, Sierra Gónzalez G, López Chávez AU. The reactogenicity and immunogenicity of the first Cuban vaccine against human leptospirosis. Revista Cubana de Medicina Tropical. 1998;50(2):159-66.

McBride AJA, Athanazio DA, Reis MG, Ko AI. Leptospirosis. Current Opinion in Infectious Diseases. 2005; 18:376-86.

McClain JB, Ballou WR, Harrison SM, Steinweg DL. Doxycycline therapy for leptospirosis. Annals of Internal Medicine. 1984;100:696-8.

Meri T, Murgia R, Stefanel P, Meri S, Cinco M. Regulation of complement activation at the C3-level by serum resistant leptospires. Microbial Pathogenesis. 2005;39:139-47.

Merien F, Truccolo J, Baranton G, Perolat P. Identification of a 36-kDa fibronectin-binding protein expressed by a virulent variant of Leptospira interrogans serovar Icterohaemorrhagiae. FEMS Microbiology Letters. 2000;185:17-22.

Merien F, Truccolo J, Rougier Y, Baranton G, Perolat P. In vivo apoptosis of hepatocytes in guinea pigs infected with Leptospira interrogans serovar icterohaemorrhagiae. FEMS Microbiology Letters. 1998;169:95-102.

Miller NG, Wilson RB. Electron microscopy of the liver of the hamster during acute and chronic leptospirosis. American Journal of Veterinary Research. 1966;27:1071-81. 
Murphy PA. Leptospirosis. Clinical conferences at the Johns Hopkins Hospital, J. Hopkins. Medical Journal. 1980;147:65-9.

Murray GL, Srikram A, Hoke DE, Wunder EA Jr, Henry R, Lo M, Zhang K, Sermswan RW, Ko AI, Adler B. The major surface protein LipL32 is not required for either acute or chronic infection with Leptospira interrogans. Infection and Immunity. In press 2008.

Nahori MA, Fournie-Amazouz E, Que-Gewirth NS, Balloy V, Chignard M, Raetz CR, Saint Girons I, Werts C. Differential TLR recognition of leptospiral lipid A and lipopolysaccharide in murine and human cells. The Journal of Immunology. 2005;175:6022-31.

Naimam BM, Alt D, Bolin CA, Zuerner R, Baldwin CL. Protective killed Leptospira borgpetersenii vaccine induces potent Th1 immunity comprising responses by CD4 and gamma-delta T lymphocytes. Infection and Immunity. 2001;69:7550-8.

Nascimento ALTO, Ko AI, Martins EAL, Monteiro-Vitorello CB, Ho PL, Haake DA, Verjovski-Almeida S, Harstkeerl RA, Marques MV, Oliveira MC, Menck CFM, Leite LCC, Carrer H, Coutinho LL, Degrave WM, Dellagostin AO, El-Dorry H, Ferro ES, Ferro MIT, Furlan LR, Gamberini M, Giglioti EA, Góes-Neto A, Goldman GH, Goldman MHS, Harakava R, Jerônimo SMB, Junqueira-de-Azevedo ILM, Kimura ET, Kuramae EE, Lemos EGM, Lemos MVF, Marino CL, Nunes LR, de Oliveira RC, Pereira GG, Reis MS, Schriefer A, Siqueira WJ, Sommer P, Tsai SM, Simpson AJG, Ferro JA, Camargo LEA, Kitajima JP, Setubal JC, Van Sluys MA. Comparative genomics of two Leptospira interrogans serovars reveals novel insights into physiology and pathogenesis. Journal of Bacteriology. 2003; 186:2164-72.

Nascimento ALTO, Verjovski-Almeida S, Van Sluys MA, Monteiro-Vitorello CB, Camargo LEA, Digiampietri LA, Harstkeerl RA, Ho PL, Marques MV, Oliveira MC, Setubal JC, Haake DA, Martins EAL. Genoma features of Leptospira interrogans serovar Copenhageni. Brazilian Journal of Medical and Biological Research. 2004;37:459-78.

Norris SJ, Weinstock GM. The genome sequence of Treponema pallidum, the syphilis spirochete: will clinicians benefit? Current Opinion in Infectious Diseases. 2000;13:29-36.

Palaniappan RU, Ramanujam S, Chang YF. Leptospirosis: pathogenesis, immunity, and diagnosis. Current Opinion in Infectious Diseases. 2007;20:284-92.

Palaniappan RUM, McDonough SP, Divers TJ, Chen C-S, Pan M-J, Matsumoto M, Chang YF. Immunoprotection of Recombinant Leptospiral Immunoglobulin-Like Protein A against Leptospira interrogans Serovar Copenhageni. Infection and Immunity. 2006; 74: 1745-50.

Park SK, Lee SH, Rhee YK, Kang SK, Kim KJ, Kim MC, Kim KW, Chang WH. Leptospirosis in Chonbuk providence of Korea in 1987: a study of 93 patients. American Journal of Tropical Medicine and Hygiene. 1989;41:345-51.

Paster JB, Dewhirst EF. Journal of Molecular Microbiology and Biotechnology. 2000;2(4):341-4.

Picardeau M, Bulach DM, Bouchier C, Zuerner RL, Zidane N, Wilson PJ, Creno S, Kuczek ES, Bommezzadri S, Davis JC, McGrath A, Johnson MJ, Boursaux-Eude C, Seemann T, 
Rouy Z, Coppel RL, Rood JI, Lajus A, Davies JK, Me'digue C, Adler B. Genome sequence of the saprophyte Leptospira biflexa provides insights into the evolution of Leptospira and the pathogenesis of leptospirosis. PLoS ONE. 2008;3:e1607.

Pizza M, Scarlato V, Masignani V, Giuliani MM, Aricò B, Comanducci M, Jennings GT, Baldi L, Bartolini E, Capecchi B, Galeotti CL, Luzzi E, Manetti R, Marchetti E, Mora M, Nuti S, Ratti G, Santini L, Savino S, Scarselli M, Storni E, Zuo P, Broeker M, Hundt E, Knapp B, Blair E, Mason T, Tettelin H, Hood DW, Jeffries AC, Saunders NJ, Granoff DM, Venter JC, Moxon ER, Grandi G, Rappuoli R. Identification of vaccine candidates against serogroup B meningococcus by whole-genome sequencing. Science. 2000;287:1816-20.

Plank R, Dean D. Overview of the epidemiology, microbiology, and pathogenesis of Leptospira spp. in humans. Microbes and Infection. 2000;2:1265-76.

Preissner KT, Chhatwal GS. Extracellular matrix and host cell surfaces: potential sites of pathogen interaction. In: Cossart P, Boquet P, Normark S, Rappuoli R. Cellular Microbiology. $2^{\text {nd }}$ ed. Washington, DC: ASM Press; 2005. p. 87-103.

Pusgley AP. The complete general secretory pathway in gram-negative bacteria. Microbiology and Molecular Biology Reviews, 1993; 57: 50-108.

Que-Gewirth NL, Ribeiro AA, Kalb SR, Cotter RJ, Bulach DM, Adler B, Girons IS, Werts C, Raetz CR. A methylated phosphate group and four amidelinked acyl chains in Leptospira interrogans lipid A. The membrane anchor of an unusual lipopolysaccharide that activates TLR2. Journal of Biological Chemistry. 2004;279:25420-9.

Ramos CRR, Abreu PAE, Nascimento ALTO, Ho PL. A high-copy T7 Escherichia coli expression vector for the production of recombinant proteins with a minimal N-terminal Histagged fusion peptide. Brazilian Journal of Medical Biological Research. 2004;37:1103-9.

Rappuoli R, Covacci A. Reverse vaccinology and Genomics. Science. 2003;302:602.

Reed LJ, Muench H. "A simple method of estimating fifty percent endpoints". The American Journal of Hygiene. 1938;27:493-7.

Ren S-X, Fu Gang, Jiangk X-G, Zeng R., Miao Y-G, Xu H, Zhang Y-X, Xiong H, Lu G, Lu L-F, Jiang H-Q, Jia J, Tu Y-F, Jiang J-X, Gu W-Y, Zhang Y-Q, Cai Z, Sheng H-H, Yin H-F, Zhang Y, Zhu G-F, Wank M, Huangk H-L, Qian Z, Wang S-Y, Ma W, Yao Z-J, Shen Y, Qiang B-Q, Xia Q-C, Guo X-K, Danchinq A, Saint Girons I, Somerville RL, Wen Y-M, Shik M-H, Chen Z, Xuk J-G, Zhao G-P. Unique physiological and pathogenic features of Leptospira interrogans revealed by whole-genome sequencing. Nature. 2003;422:888-93.

Ristow P, Bourhy P, da Cruz McBride FW, Figueira CP, Huerre M, Ave P, Girons IS, Ko AI, Picardeau M. PLoS pathogen. 2007;e97,3:894-903.

Ristow P, Bourhy P, Kerneis S, Schmitt C, Prevost M-C, Lilenbaum W, Picardeau M. Biofilm formation by saprophytic and pathogenic leptospires Microbiology. 2008;154:1309-17.

Rodriguez-Gonzalez I, Fillonneau C, Blanchet B, Suard I, Catilina P, Andre-Fontaine G. Efficacy of Spirolept vaccine against human leptospirosis as estimated by passive protection of laboratory rodents. Medical Malpractice Infection. 2004;34(5):196-200. 
Sambrook J, Fritsch EF, Maniatis T. Molecular cloning: A Laboratory manual. $2^{\mathrm{a}}$ ed. New York: Cold Spring Harbor Laboratory Press; 1989.

Sanger F, Nicklen S, Coulson AR. DNA sequencing with chain-terminating inhibitors. Proceeding of National Academy Sciences of the United States of America. 1977;74:5463-7.

Shenberg E. Growth of pathogenic Leptospira in chemically defined media. Journal of Bacteriology. 1967;93:1598-606.

Schmid GP. Epidemiology and clinical similarities of human spirochetal diseases. Reviews of Infectious Diseases. 1989;11:1460-9.

Schröder NWJ, Eckert J, Stübs G, Schumann RR. Immune responses induced by spirochetal outer membrane lipoproteins and glycolipids. Immunobiology. 2008;213:329-40.

Seijo A, Coto H, San Juan J, Videla J, Deodato B, Cernigoi B, Messina OGO, de Bassadoni CD, R Schtirbu, Olenchuk A, de Mazzonelli GD, Parma A. Lethal leptospiral pulmonary hemorrhage: an emerging disease in Buenos Aires, Argentina. Emergin Infectious Diseases Journal. 2002;8:1004-5.

Seguro AC, Lomar AV, Rocha AS. Acute renal failure of leptospirosis: nonoliguric and hypokalemic forms. Nephron. 1990;55:146-51.

Sehgal SC, Murhekar MV, Sugunan AP. Outbreak of leptospirosis with pulmonary involvement in north Andaman. Indian Journal of Medical Research. 1995;102:9-12.

Seixas FK, da Silva EF, Hartwig DD, Cerqueira GM, Amaral M, Fagundes MQ, Dossa RG, Dellagostin AO. Recombinant Mycobacterium bovis BCG expressing the LipL32 antigen of Leptospira interrogans protects hamsters from challenge. Vaccine. 2007;26:88-95.

Seshadri R, Myers GS, Tettelin H, Eisen JA, Heidelberg JF, Dodson RJ, Davidsen TM, DeBoy R.T, Fouts DE, Haft DH, Selengut J, Ren Q, Brinkac LM, Madupu R, Kolonay J, Durkin, SA, Daugherty SC, Shetty J, Shvartsbeyn A, Gebregeorgis E, Geer K, Tsegaye G, Malek J, Ayodeji B, Shatsman S, McLeod MP, Smajs D, Howell JK, Pal S, Amin A, Vashisth P, McNeill TZ, Xiang Q, Sodergren E, Baca E, Weinstock GM, Norris SJ, Fraser CM, Paulsen IT. Comparison of the genome of the oral pathogen Treponema denticola with other spirochete genomes. Proceeding of National Academy Sciences of the United States of America. 2004;101:5646-51.

Setubal JC, Reis M, Matsunaga J, Haake D.A. Lipoprotein computational prediction in spirochaetal genomes. Microbiology. 2006;152:113-21.

Shang ES, Summers TA, Haake D.A. Molecular cloning and sequence analysis of the gene enconding LipL41, a surface-exposed lipoprotein of pathogenic Leptospira species. Infection and Immunity. 1996; 64: 2322-30.

Silva EF, Medeiros MA, McBride AJ, Matsunaga J, Esteves GS, Ramos JG, Santos CS, Croda J, Homma A, Dellagostin OA, Haake DA, Reis MG, Ko AI. The terminal portion of leptospiral immunoglobulin-like protein LigA confers protective immunity against lethal infection in the hamster model of leptospirosis. Vaccine. 2007;25(33):6277-86. 
Simpson FG, Green KA, Haug GJ, Brookes DL. Leptospirosis associated with severe pulmonary haemorrhage in Far North Queensland. The Medical Journal of Australia. 1998;169:151-3.

Stevenson B, Choy HA, Pinne M, Rotondi ML, Miller MC, Demoll E, Kraiczy P, Cooley AE, Creamer TP, Suchard MA, Brissette CA, Verma A, Haake DA. Leptospira interrogans endostatin-like outer membrane proteins bind host fibronectin, laminin and regulators of complement. PLoS ONE. 2007;2:e1188.

Swancutt MA, Riley BS, Radolf JD, Norgard MV. Molecular characterization of the pathogen-specific, 34-kilodalton membrane immunogen of Treponema pallidum. Infection and Immunity. 1989;57:3314-23.

Takayama K, Rothenberg RJ, Barbour AG. Absence of lipopolysaccharide in the Lyme disease spirochete, Borrelia burgdorferi. Infection and Immunity. 1987;55:2311-13.

Trevejo RT, Rigau-Pérez JG, Ashford DA, McClure EM, Jarquain-Gonzaalez C, Amador JJ, De Los Reyes JO, Gonzalez A, Zaki SR, Shieh WJ, McLean RG, Nasci RS, Weyant RS, Bolin CA, Braag SL, Perkins BA, Spiegel RA. Epidemic leptospirosis associated with pulmonary hemorrhage Nicaragua, 1995. The Journal of Infectious Diseases. 1998;178:145763.

Van Crevel R, Speelman P, Gravekamp C, Terpstra WJ. Leptospirosis in travelers. Clinical Infectious Diseases. 1994;19:132-14.

Vinetz JM. Leptospirosis. Current Opinion in Infectious Diseases. 2001;14:527-38.

Walker SG, Xu X, Altman E, Davis KJ, Ebersole JL, Holt SC. Isolation and chemical analysis of a lipopolysaccharide from the outer membrane of the oral anaerobic spirochete Treponema pectinovorum. Oral Microbiology Immunology. 1999;14:304-8.

Werts C, Tapping RI, Mathison JC, Chuang TH, Kravchenko V, Saint Girons I, Haake DA, Godowski PJ, Hayashi F, Ozinsky A, Underhill DM, Kirschning CJ, Wagner H, Aderem A, Tobias PS, Ulevitch RJ. Leptospiral lipopolysaccharide activates cells through a TLR2dependent mechanism. Nature Immunology. 2001;2:346-52.

Wizemann TM, Heinrichs JH, Adamou JE, Erwin AL, Kunsch C, Choi GH, Barash SC, Rosen CA, Masure HR, Tuomanen E, Gayle A, Brewah YA, Walsh W, Barren P, Lathigra R, Hanson M, Langermann S, Johnson S, Koenig S. Use of a whole genome approach to identify vaccine molecules affording protection against Streptococcus pneumoniae infection. Infection and Immunity. 2001;69:1593-8.

WHO, World Health Organization Human leptospirosis: guindance for diagnosis, surveillance and control, 2003. International Leptospirosis Society, 2003.

Wu HC. Biosynthesis of lipoproteins. In: Escherichia coli and Salmonella: Cellular and Molecular Biology. $2^{\text {nd }}$ ed. Washington, DC: American Society for Microbiology; 1996. p. 1005-1014. 
Yang CW, Wu MS, Pan MJ, Hsieh WJ, Vandewalle A, Huang CC. The Leptospira outer membrane protein LipL32 induces tubulointerstitial nephritis-mediated gene expression in mouse proximal tubule cells. Journal of American Society of Nephrology. 2002;8:2037-45.

Yan Y, Chen Y, Liou W, Ding J, Chen J, Zhang J, Zhang A, Zhou W, Gao Z, Ye X, Xiao Y. An evaluation of the serological and epidemiological effects of the outer envelope vaccine to leptospira. Journal of Chinese Medical Association. 2003;66(4):224-30.

Yang C-W, Hung C-C, Wu M-S, Tian Y-C, Chang C-T, Pan M-J, Vandewalle A. Toll-like receptor 2 mediates early inflammation by leptospiral outer membrane proteins in proximal tubule cells. Kidney international. 2006;69:815-822.

Yasuda PH, Steigerwalt AG, Sulzer KR, Kaufmann AF., Rogers F, Brenner DJ. Deoxyribonucleic acid relatedness between serogroups and serovars in the family Leptospiraceae with proposals for seven new Leptospira species. International Journal of Systematic Bacteriology. 1987;37:407-15.

Zhang YX, Geng Y, BI B, HE JY, Wu CF, Guo XK, Zhao GP. Identification and classification of all potential hemolysin encoding genes and their products from Leptospira interrogans serogroup Icterohae-morragiae serovar Lai. Acta Pharmacologia Sinica. $2005 ; 4: 453-61$. 


\section{ANEXOS \\ ANEXO A - Trabalhos publicados em revistas científicas}

Hauk P, Negrotto S, Romero EC, Vasconcellos AS, Genovez M E, Ward, R J, Schattner M, Gómez R M, Ho PL. Expression and characterization of hemolysin from Leptospira interrogans serovar Copenhageni: Potentiation of hemolytic activity by LipL32. Biochemical and Biophysical Research Communications. 2005;333:1341-7.

Hauk P, Negrotto S, Romero EC, Vasconcellos AS, Genovez M E, Ward, R J, Schattner M, Gómez R M, Ho PL. Expression and characterization of hemolysin from Leptospira interrogans serovar Copenhageni: Potentiation of hemolytic activity by LipL32. 2008;372:948. Corrigendum in: Hauk P, Negrotto S, Romero CE, Vasconcellos SA, Genovez EC, Ward RJ, Schattner M, Gómez RM, Ho PL. Biochemical and Biophysical Research Communications. 2005;333:1341-7.

Hauk P, Macedo F, Romero CE, Vasconcellos SA, de Morais ZM, Barbosa AS, Ho PL. In LipL32, the Major Leptospiral Lipoprotein, the C Terminus Is the Primary Immunogenic Domain and Mediates Interaction with Collagen IV and Plasma Fibronectin. Infection and Immunity. 2008;76:2642-50.

\section{ANEXO B - Trabalhos submetidos para publicação em revistas científicas}

Hauk P, Guzzo CR, Ho PL, Farah CS. Crystallization and preliminary X-ray analysis of LipL32 from Leptospira interrogans sorovar Copenhageni.

Hauk P, Guzzo RC, Roman- Ramos H, Ho PL, Farah CS. Structure and calcium binding activity of LipL32, the major surface antigen of pathogenic Leptospira sp. 


\title{
Expression and characterization of HlyX hemolysin from Leptospira interrogans serovar Copenhageni: Potentiation of hemolytic activity by LipL32
}

\author{
Pricila Hauk ${ }^{\mathrm{a}, \mathrm{b}}$, Soledad Negrotto ${ }^{\mathrm{c}}$, Eliete Caló Romero ${ }^{\mathrm{d}}$, Sílvio Arruda Vasconcellos ${ }^{\mathrm{e}}$, \\ Margareth Élide Genovez ${ }^{\mathrm{f}}$, Richard John Ward ${ }^{\mathrm{g}}$, Mirta Schattner ${ }^{\mathrm{c}}$, \\ Ricardo Martín Goméz ${ }^{\mathrm{h}, *}$, Paulo Lee Ho ${ }^{\mathrm{a}, \mathrm{b}, \mathrm{i}, *}$ \\ ${ }^{a}$ Centro de Biotecnologia, Instituto Butantan, São Paulo, Brazil \\ ${ }^{\mathrm{b}}$ Interunidades em Biotecnologia, Instituto de Ciências Biomédicas da USP, São Paulo, Brazil \\ ${ }^{\mathrm{c}}$ Department of Thrombosis and Haemostasis, Hematological Research Institute, National Academy of Medicine, \\ National Research Council (CONICET), Buenos Aires, Argentina \\ ${ }^{\mathrm{d}}$ Departamento de Biologia Médica, Instituto Adolfo Lutz, São Paulo, Brazil \\ e Departamento de Medicina Veterinária Preventiva e Saúde Animal, Faculdade de Medicina Veterinária e Zootecnia da USP, São Paulo, Brazil \\ ${ }^{\mathrm{f}}$ Centro de Pesquisa e Desenvolvimento de Sanidade Animal, Instituto Biológico, São Paulo, Brazil \\ g Departamento de Química, Faculdade de Filosofia, Ciências e Letras de Ribeirão Preto da USP, São Paulo, Brazil \\ ${ }^{\mathrm{h}}$ Biochemistry and Molecular Biology Institute, Department of Biological Sciences, Faculty of Exact Sciences, National University of La Plata, \\ CONICET, La Plata, Argentina \\ ${ }^{\mathrm{i}}$ Instituto de Biociências e Instituto de Química da USP, São Paulo, Brazil
}

Received 3 June 2005

Available online 20 June 2005

\begin{abstract}
The HlyX, a putative hemolysin identified from the Leptospira genomes, was cloned, expressed in Escherichia coli, purified, and its hemolytic activity was confirmed. Mouse polyclonal antiserum against the recombinant HlyX recognized HlyX-related antigens in a panel of Leptospira species extracts and it was also able to abolish the hemolytic activity of HlyX. A mixture of HlyX and LipL32, a known hemolysin from Leptospira, induced hemolysis in a synergistic way that was fully inhibited by antiserum against either protein. Moreover, sera from patients with leptospirosis also recognized the recombinant HlyX, showing that it is presented to the host immune system during Leptospira infection.
\end{abstract}

(C) 2005 Elsevier Inc. All rights reserved.

Keywords: HlyX; Hemolysin; LipL32; Leptospira interrogans serovar Copenhageni; Leptospirosis

Leptospirosis is a widespread antropozoonosis caused by pathogenic spirochetes belonging to the genus Leptospira which in recent years has emerged as an important global and veterinary health problem. The genus Leptospira presents more than 200 pathogenic ser-

\footnotetext{
${ }^{*}$ Corresponding authors. Fax: +55 1137261505 (P.L. Ho).

E-mail addresses: rmg@biol.unlp.edu.ar (R.M. Goméz), hoplee@ (P.L. HO) butantan.gov.br (P.L. Ho).
}

ovars, which are classified by their agglutination after cross-adsorption with homologous antigen, related to the variations in the carbohydrate side chains of the lipopolysaccharide (LPS) [1,2]. The diseases caused by pathogenic Leptospira include subclinical infection, self-limited anicteric febrile illness (both with and without meningitis), and the severe and potentially lethal Weil's syndrome that is characterized by hemorrhage, renal failure, and jaundice. The primary lesions to small 
Corrigendum

\title{
Corrigendum to "Expression and characterization of HlyX hemolysin from Leptospira interrogans serovar Copenhageni: Potentiation of hemolytic activity by LipL32” [Biochem. Biophys. Res. Commun. 333 (2005) 1341-1347]
}

\author{
Pricila Hauk a,b ${ }^{\mathrm{a}}$, Soledad Negrotto ${ }^{\mathrm{c}}$, Eliete Caló Romero ${ }^{\mathrm{d}}$, Sílvio Arruda Vasconcellos ${ }^{\mathrm{e}}$, \\ Margareth Élide Genovez ${ }^{\mathrm{f}}$, Richard John Ward ${ }^{\mathrm{g}}$, Mirta Schattner ${ }^{\mathrm{c}}$, Ricardo Martín Gómez ${ }^{\mathrm{h}, *}$, \\ Paulo Lee $\mathrm{Ho}^{\mathrm{a}, \mathrm{b}, \mathrm{i}, *}$ \\ ${ }^{a}$ Centro de Biotecnologia, Instituto Butantan, São Paulo, Brazil \\ ${ }^{\mathrm{b}}$ Interunidades em Biotecnologia, Instituto de Ciências Biomédicas da USP, São Paulo, Brazil \\ ${ }^{\mathrm{c}}$ Department of Thrombosis and Haemostasis, Hematological Research Institute, National Academy of Medicine, National Research Council (CONICET), Buenos Aires, Argentina \\ ${ }^{\mathrm{d}}$ Departamento de Biologia Médica, Instituto Adolfo Lutz, São Paulo, Brazil \\ ${ }^{\text {e }}$ Departamento de Medicina Veterinária Preventiva e Saúde Animal, Faculdade de Medicina Veterinária e Zootecnia da USP, São Paulo, Brazil \\ ${ }^{\mathrm{f}}$ Centro de Pesquisa e Desenvolvimento de Sanidade Animal, Instituto Biológico, São Paulo, Brazil \\ ${ }^{\mathrm{g}}$ Departamento de Química, Faculdade de Filosofia, Ciências e Letras de Ribeirão Preto da USP, São Paulo, Brazil \\ ${ }^{\mathrm{h}}$ Biochemistry and Molecular Biology Institute, Department of Biological Sciences, Faculty of Exact Sciences, National University of La Plata, CONICET, La Plata, Argentina \\ ${ }^{\mathrm{i}}$ Instituto de Biociências e Instituto de Química da USP, São Paulo, Brazil
}

We reported the detection of hemolytic activity by HlyX and LipL32 of Leptospira interrogans serovar Copenhageni. However, this activity was not confirmed and the hemolysis observed was due to traces of the detergent Triton X-114 used to remove endotoxins. The negative controls composed only of the specific sera against the recombinant proteins were able to abolish the hemolytic activity, probably due to the presence of plasma albumin, which binds the detergent [1,2]. All the other results described in the article were confirmed.

\section{References}

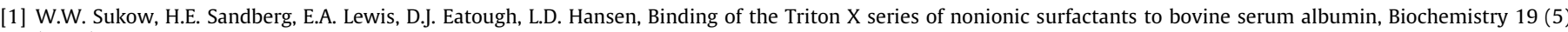
(1980) 912-917.

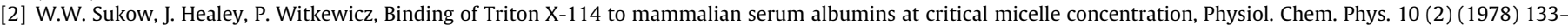
138. 


\title{
In LipL32, the Major Leptospiral Lipoprotein, the C Terminus Is the Primary Immunogenic Domain and Mediates Interaction with Collagen IV and Plasma Fibronectin ${ }^{\nabla}$
}

\author{
Pricila Hauk, ${ }^{1,2}$ Felipe Macedo, ${ }^{1}$ Eliete Caló Romero, ${ }^{3}$ Sílvio Arruda Vasconcellos, ${ }^{4}$ \\ Zenaide Maria de Morais, ${ }^{4}$ Angela Silva Barbosa, ${ }^{1,5 *}$ and Paulo Lee Ho ${ }^{1,2 *}$ \\ Centro de Biotecnologia, Instituto Butantan, 05503-900 São Paulo, SP, Brazil'1 Programa de Pós-Graduação Interunidades em \\ Biotecnologia USP/IPT/Instituto Butantan, Instituto de Ciências Biomédicas da USP, 05508-900 São Paulo, SP, Brazil²; \\ Seção de Bacteriologia, Instituto Adolfo Lutz, 01246-902 São Paulo, SP, Brazil ${ }^{3}$; Faculdade de \\ Medicina Veterinária e Zootecnia, Universidade de São Paulo, 05508-270 São Paulo, \\ SP, Brazil ${ }^{4}$; and Laboratório de Bacteriologia, Instituto Butantan, \\ 05503-900 São Paulo, SP, Brazil ${ }^{5}$
}

Received 10 December 2007/Returned for modification 27 January 2008/Accepted 26 March 2008

\begin{abstract}
LipL32 is the major leptospiral outer membrane lipoprotein expressed during infection and is the immunodominant antigen recognized during the humoral immune response to leptospirosis in humans. In this study, we investigated novel aspects of LipL32. In order to define the immunodominant domains(s) of the molecule, subfragments corresponding to the N-terminal, intermediate, and C-terminal portions of the LipL32 gene were cloned and the proteins were expressed and purified by metal affinity chromatography. Our immunoblot results indicate that the C-terminal and intermediate domains of LipL32 are recognized by sera of patients with laboratory-confirmed leptospirosis. An immunoglobulin $M$ response was detected exclusively against the LipL32 C-terminal fragment in both the acute and convalescent phases of illness. We also evaluated the capacity of LipL32 to interact with extracellular matrix (ECM) components. Dose-dependent, specific binding of LipL32 to collagen type IV and plasma fibronectin was observed, and the binding capacity could be attributed to the $\mathrm{C}$-terminal portion of this molecule. Both heparin and gelatin could inhibit LipL32 binding to fibronectin in a concentration-dependent manner, indicating that the 30-kDa heparin-binding and 45-kDa gelatin-binding domains of fibronectin are involved in this interaction. Taken together, our results provide evidence that the LipL32 $\mathrm{C}$ terminus is recognized early in the course of infection and is the domain responsible for mediating interaction with ECM proteins.
\end{abstract}

Leptospirosis, caused by spirochetes of the genus Leptospira, is a widespread zoonosis that remains a public health concern, notably in tropical and subtropical regions. Humans become infected through contact with water, food, or soil containing urine from infected animals. Clinical manifestations range from mild (subclinical infection) to severe and potentially lethal forms characterized by high fever, intense jaundice, bleeding, renal and pulmonary dysfunction, neurologic alterations, and cardiovascular collapse. Pulmonary hemorrhage has been reported to be increasing in recent years, affecting up to $70 \%$ of the patients, and has been considered a serious life-threatening concern, becoming the main cause of death due to leptospirosis in some countries $(3,17,26,35)$.

Within the last few years, considerable research has been conducted on outer membrane proteins expressed by Leptospira spp. during infection, prompted by the necessity of developing subunit vaccines or characterizing antigens suitable for early immunodiagnosis of the disease. In this context, pu-

\footnotetext{
* Corresponding author. Mailing address for Angela Silva Barbosa: Centro de Biotecnologia/Laboratório de Bacteriologia, Instituto Butantan, 05503-900 São Paulo, SP, Brazil. Phone: 55-11-3726-7222, ext. 2261. Fax: 55-11-3726-1505. E-mail: angelabarbosa@butantan.gov.br. Mailing address for Paulo Lee Ho: Centro de Biotecnologia, Instituto Butantan, 05503-900 São Paulo, SP, Brazil. Phone: 55-11-3726-7222, ext. 2244. Fax: 55-11-3726-1505. E-mail: hoplee@butantan.gov.br.

${ }^{\nabla}$ Published ahead of print on 7 April 2008.
}

tative virulence factors presumed to have a role in adhesion to host tissues, such as the Lig proteins (11) and the leptospiral endostatin-like (Len) outer membrane proteins $(1,37)$, as well as in complement evasion (LenA/LenB) $(37,38)$, constitute attractive vaccine candidates.

The most abundant antigen found in the leptospiral total protein profile is LipL32 (40), a lipoprotein displaying a calculated molecular mass of $26.7 \mathrm{kDa}$ but an observed electrophoretic mobility of approximately $32 \mathrm{kDa}(22)$. LipL32 is highly conserved among pathogenic Leptospira species (22) but has no orthologs in the saprophyte Leptospira biflexa (32). It has been shown to enhance hemolysis mediated by sphingomyelinase $\mathrm{SphH}$, and for this reason, the protein was also identified as hemolysis-associated protein Hap-1 (25). Expressed at high levels both during cultivation and during natural infection, LipL32 was shown to be surface exposed and highly immunogenic $(14,15,21,22)$. It has been evaluated as an antigen for immunodiagnosis $(4,16,19)$ and as a vaccine antigen, showing protection against Leptospira interrogans challenge in animals immunized with recombinant adenovirus (6), DNA vaccine (7), or recombinant Mycobacterium bovis BCG (36).

In this work, we investigated novel aspects of LipL32. First, we aimed to define the immunogenic portions of the molecule. Our data indicate that both the $\mathrm{C}$ terminus and the intermediate portion of LipL32 are recognized by human sera, with the 


\title{
Crystallization and preliminary X-ray analysis of LipL32 from Leptospira interrogans sorovar Copenhageni
}

\author{
* To whom correspondence should be addressed \\ P.L.H.: hoplee@ butantan.gov.br \\ C.S.F.: chsfarah@iq.usp.br
}

Pricila Hauk ${ }^{\mathrm{a}, \mathrm{b}}$, Cristiane R. Guzzo ${ }^{\mathrm{c}}$, Paulo L. Ho $\mathrm{H}^{\mathrm{a}, \mathrm{b}, \mathrm{c}^{*}}$ and Chuck S. Farah ${ }^{\mathrm{c}^{*}}$

${ }^{a}$ Centro de Biotecnologia, Instituto Butantan, CEP 05503-900, São Paulo, SP, Brazil; ' Programa de Pós-Graduação Interunidades em Biotecnologia USP/IPT/Instituto Butantan, Instituto de Ciências Biomédicas da USP, CEP 05508-900, São Paulo, SP, Brazil and ' Departamento de Bioquímica, Instituto de Química, Universidade de São Paulo, CEP 05508-000, SP, Brazil.

\begin{abstract}
LipL32 is a major surface protein expressed during infection by pathogenic Leptospira. Here, the crystallization of the 253-residue (27.68 kDa) LipL32 protein is described. Recombinant LipL32 containing selenomethionine was crystallized in space group $\mathrm{P}_{2} 21$ and crystals diffracted to $2.25 \AA$ resolution at a synchrotron source. The unit-cell parameters are $a=b=126.725 \AA$ and $c=$ $95.996 \AA$. The calculated Mathews coefficient suggests the presence of two LipL32 molecules in the asymmetric unit.
\end{abstract}


Structure and calcium binding activity of LipL32, the major surface antigen of pathogenic Leptospira sp.

Pricila Hauk ${ }^{1,2 \#}$, Cristiane Rodrigues Guzzo ${ }^{3 \#}$, Henrique Roman Ramos ${ }^{1,3}$, Paulo Lee $\mathrm{Ho}^{1,2,3^{*}}$ and Chuck Shaker Farah ${ }^{3^{*}}$

${ }^{1}$ Centro de Biotecnologia, Instituto Butantan, CEP 05503-900, São Paulo, SP, Brazil; ${ }^{2}$ Programa de Pós-Graduação Interunidades em Biotecnologia USP/IPT/Instituto Butantan, Instituto de Ciências Biomédicas da USP, CEP 05508-900, São Paulo, SP, Brazil and ${ }^{3}$ Departamento de Bioquímica, Instituto de Química, Universidade de São Paulo, CEP 05508-000, SP, Brazil.

\# These authors equally contributed to this work

* Correspondence: chsfarah@iq.usp.br and hoplee@butantan.gov.br

Running title: Structure and calcium binding activity of LipL32

Keywords: Leptospira, LipL32, jelly-roll fold, calcium-binding. 


\section{SUMMARY}

Leptospirosis, a spirochaetal zoonotic disease caused by Leptospira, has been recognized as an important emerging infectious disease. LipL32 is the major exposed outer membrane protein (OMP) found exclusively in pathogenic leptospires, where it accounts for up to $75 \%$ of the total OMPs. It is highly immunogenic, and recent studies have implicated LipL32 as an extracellular matrix (ECM) binding protein, interacting with collagens, fibronectin and laminin. In order to better understand the biological role and the structural requirements for the function of this important lipoprotein, we have determined the $2.25 \AA$ resolution structure of recombinant LipL32 protein corresponding to residues 21-272 of the wild-type protein (LipL32 21-272). The LipL32 21-272 monomer is made of a jelly-roll fold core from which protrude several peripheral secondary structures. LipL32 $21-272$ is structurally similar to several other jelly-roll proteins, some of which bind calcium ions and extracellular matrix proteins. Indeed, spectroscopic data (circular dichroism, intrinsic tryptophan fluorescence and extrinsic 1-amino-2-naphthol-4-sulfonic acid fluorescence) confirmed the calcium binding properties of LipL32 $21-272 . \mathrm{Ca}^{2+}$-binding resulted in a significant increase in the thermal stability of the protein and binding was specific for $\mathrm{Ca}^{2+}$ as no structural or stability perturbations were observed for $\mathrm{Mg}^{2+}, \mathrm{Zn}^{2+}$ or $\mathrm{Cu}^{2+}$. Careful examination of the crystallographic structure suggests the locations of putative regions that could mediate $\mathrm{Ca}^{2+}$ binding as well as binding to other interacting host proteins, such as collagens, fibronectin and laminin. 


\section{INTRODUCTION}

A significant increase in the knowledge of Leptospira interrogans biology has been obtained in recent years ${ }^{1 ; 2}$. However, many fundamental aspects of virulence and pathogenicity of this worldwide and disseminated zoonotic spirochete remain unknown. Bacterial outer membranes mediate the principal interactions between the pathogen and its host. For this reason, a great deal of effort is being invested in understanding the properties of the leptospiral outer membrane components. The most abundant antigen found in the leptospiral total protein profile is LipL32 ${ }^{3}$. This lipoprotein is highly conserved among pathogenic Leptospira species ${ }^{4}$ but not observed in the non-pathogenic saprophytic $L$. biflex ${ }^{4 ; 5}$, though an ortholog protein was identified in the marine bacterium Pseudoalteromonas tunicata genome ${ }^{6}$. Expressed at high levels both during cultivation and natural infection, LipL32 was shown to be the most abundant outer membrane surface-exposed antigen and to be highly immunogenic. LipL32 is anchored to the outer membrane via removal of an $\mathrm{N}$ terminal signal peptide and covalent modification of the amino-terminal cysteine residue by a fatty acid at the nitrogen atom and a diacylglyceryl at the sidechain sulfur $4 ; 7 ; 8 ; 9 ; 10$. This protein was also considered a promising target for vaccine development ${ }^{11 ; 12 ; 13}$ and diagnosis ${ }^{9 ; 14 ; 15 ; 16}$ of leptospirosis. Immunoblot studies indicated that the C-terminal and intermediate domains of LipL32 are recognized by sera of patients and an IgM response was detected exclusively against the LipL32 C-terminus in both the acute and convalescent phases of illness ${ }^{17}$. LipL32 has also been shown to interact with extra-cellular matrix 
(ECM) proteins. Specific binding of LipL32 to collagen I, collagen $\mathrm{V}$, laminin ${ }^{6}$, collagen IV and plasma fibronectin ${ }^{17}$ has been observed. Furthermore, dosedependent binding to collagen IV and fibronectin could be attributed to the Cterminal portion of this molecule (amino acids 185-272) in a manner comparable to that observed for the fragment corresponding to the full-length mature protein minus the N-terminal cysteine (LipL32 $21-272)^{17}$. Recently, studies using a lipL32 mutant obtained by transposon mutagenesis in Leptospira interrogans showed that LipL32 does not play a essential role in either acute or chronic models of animal infection ${ }^{18}$. While these data did not identify an indispensible role in pathogenesis, it does not exclude an important function for LipL32 in mediating the host-pathogen interaction. In the present study, we have solved the tertiary structure of LipL32 $21-272$ as a fundamental step towards understanding of its structure-function relationships. The resolved tertiary structure showed a jelly roll fold similar to those presented by some calcium-binding and ECM-binding proteins. Additional biochemical characterizations confirmed the capacity of LipL32 to bind calcium ions. 


\section{RESULTS AND DISCUSSION}

\section{LipL32 Structure}

Recombinant LipL32 $21-272$ containing selenometionine was crystallized in space group $\mathrm{P} 3{ }_{2} 21^{19}$. This fragment corresponds to the full-length protein minus the $\mathrm{N}$-terminal lipid-anchored cysteine residue. The datasets from two crystals ${ }^{19}$ were used to resolve the structure. Initial phases were estimated by multiwavelength anomalous dispersion (MAD) phasing using a dataset that diffracted to $2.93 \AA$. These phases were subsequently extended to higher resolution using a dataset that contained reflections to $2.25 \AA^{19}$. While the initial Matthews coefficient analysis suggested 3 or 4 molecules in the asymmetric unit, the final model contained only two monomers (Mathews coefficient $=4.03$ ) and $69.5 \%$ solvent. The refined structure converged to $R_{\text {work }}$ and $R_{\text {free }}$ values of 0.184 and 0.227, respectively. Refinement data statistics are shown in Table 1. The two monomers in the asymmetric unit are related by a non-crystallographic two-fold axis and are very similar in structure, with a RMSD of $0.6 \AA$ for all atoms. Residues 21-23, 40-45, 160-163, 265-272 from chain A and residues 21-24, 159-164, 263-272 from chain B could not be modeled due to absence of electron density. 295 water molecules were modeled, as well as one chloride ion, one triethanolamine and two oxalate ions (see below).

The monomer has approximate dimensions of $36 \AA$ x $46 \AA$ x $42 \AA$ (not including the $\beta 1-\beta 2$ hairpin) and is built around a central jelly-fold $\beta$-sandwich topology of $8 \beta$-strands (strands $3,5,6,8,9,10,11,12$ ) from which protrude loops that carry the other secondary structure elements (Fig. 1a,b). Some of these peripheral structures are $\beta$-strands $(\beta 4, \beta 7$ and $\beta 13)$ that associate with 
the edges of the central $\beta$-sandwich. Four alpha helices and two $3_{10}$ helices are also found in these loops (Fig. 1a,b). The two $3_{10}$ helices are both found in a stretch between $\beta 10$ and $\beta 11.3_{10} 1$ is two turns in length (residues 193-198) while $3_{10} 2$ is made up of only one turn (residues 201-203). The loop between $\alpha 3$ and $\beta 9$ (residues 154-169), contains a large proportion of acidic amino acids (AKPVQKLDDDDDGDD) of which those underlined are disordered with no significant electron density in both monomers).

One conspicuous feature of the LipL32 $21-272$ structure is an N-terminal $\beta$ hairpin $(\beta 1-\beta 2)$ that protrudes from the more compact portion of the molecule. This hairpin has a $\beta$-bulge at its base in which the T49 carboxyl group forms hydrogen bonds with the backbone amides of L35 and S36. The hairpin is preceded by an $\mathrm{N}$-terminal linker that adopts a non-repetitive, extended and highly solvent-exposed conformation (Fig. 1a). This linker interacts with the external face of one of the $\beta$-sandwich layers via a small set of hydrophobic and polar interactions.

\section{Monomer contacts in the crystal and possible quarternary structure}

Size exclusion chromatography analysis shows that LipL32 $21-272$ migrates with an apparent molecular mass of $34 \mathrm{kDa}$ in Superdex 75 size exclusion chromatography in $150 \mathrm{mM}$ TrisHCl $(\mathrm{pH} 8), 50 \mathrm{mM} \mathrm{KCl}$, +/- $2 \mathrm{mM}$ $\mathrm{CaCl}_{2}$ (data not shown). This value is slightly greater than the calculated molecular mass of $28 \mathrm{kDa}$. Analysis of the contacts between monomers in the crystal revealed two monomer-monomer interactions that bury a significant amount of surface area. The greatest amount of buried surface is found at the 
dimer interface observed between the two monomers in the asymmetric unit dimer (PISA server Complexation Significance Score $=0.967 ;{ }^{20}$ (Fig. 1c). This interface (interface 1 ) buries a total of $1156 \AA^{2}$ per monomer and can be divided into two regions: i) Contacts between equivalent surfaces of the $\mathrm{N}$-terminal $\beta 1$ $\beta 2$ hairpins (Fig. 1c,d) that involves the side-chains of some hydrophobic as well as several hydrophilic residues (L35, S36, D38, I40, P41, V47, T49, L50, L51, P52). The electron density for some of these side-chains are not well defined in the electron density map, so specific hydrogen bond contacts could not be identified with confidence. ii) Contacts mediated by residues in the following loops from each monomer: $\beta 6-\beta 7, \alpha 2-\beta 8, \quad \beta 9-\beta 10, \beta 11-\beta 12$. Here all hydrophobic and hydrogen bonding contacts are well defined in the electron density maps.

A second dimer interface (interface 2) identified by the PISA server involves $A$ and $B$ chains from asymmetric units related by a crystallographic two-fold axis (symmetry operation $x-y,-y+1,-z+1 / 3)(F i g .1 e)$. This interface has a less significant Complexation Significance Score of 0.455 , buries $832 \AA^{2}$ per monomer and involves the following loops from each monomer $\beta 5-\beta 6, \beta 8-\alpha 3$, $\alpha 3-\beta 9$ (acidic loop), the loop between $\beta 10$ and $\beta 11$ containing the two $3_{10}$ helices, $\beta 12-\beta 13$ and the C-terminus of $\alpha 4$. Combining these two interfaces produces a linear zig-zag polymer that runs parallel to the crystallographic aaxis (Supplementary information Figure S1). 


\section{Comparison of LipL32 $21-272$ with other protein structures}

LipL32 $21-272$ has no significant sequence similarity with proteins of known structure. We therefore used the Dali program ${ }^{21}$ to search for protein structures with topologies similar to that of LipL32 $21-272$. This analysis found a small group of proteins with Z-scores above 5.0 (Table 2). They can be arranged into the following groups: mammalian calpains, a bacterial collagenase, bacterial toxins, viral coat proteins and the kexin2 peptidase and representative examples are shown in Fig. 1f. All these proteins share a common jelly-roll fold topology at their core (shown in blue in Figs 1a and 1f) but all differ in the nature and number of secondary structure elements inserted in the loops between these strands.

The structure with the highest Dali z-score (8.8) was that of the isolated domain III from human calpain 7 (pdb 2qfe; unpublished) which is distinguished from the others by the presence of a C-terminal $\beta$-strand that is topologically analogous to $\beta 13$ of LipL32 $21-272$ (Fig. 1a and 1f). Van Itallie et al. ${ }^{22}$ recognized a structural relationship between the receptor binding domains of several bacterial toxins including Clostrifium perfringens enterotoxin (pdb 2quo), C. histolyticum class I collagenase ColG C-terminus (1nqd) and the large Cry family of toxins (Figure 1f). The first two are significantly similar to the LipL32 21 272 structure (Table 2 ) but differ due the presence of an $\mathrm{N}$-terminal $\beta$-strand that runs anti-parallel to $\beta 13$ in LipL32 $21-272$ (Fig. 1a, and 1f). An interesting feature of these proteins is that residues in their C-terminal regions are involved in binding to their protein targets ${ }^{23 ; 24}$. 


\section{Possible calcium-binding sites in LipL32}

The protein structure-function relationships between these jelly-roll fold domains are not clear but many listed in Table 2 have been shown to bind calcium ions. For example, domain III from calpain, collagen-binding domain (CBD) from ColG, and many icosahedral RNA coat proteins, undergo significant structural rearrangements upon binding calcium ${ }^{24 ; 25 ; 26 ; 27 . ~ I n ~ t h e ~ c a s e ~ o f ~ C o l G, ~}$ the $\mathrm{Ca}^{2+}$-bound structure of the collagen-binding domain adopts a jelly-roll fold with two extra N-terminal $\beta$-strands ${ }^{24}$ (Fig. 1f). This domain binds two $\mathrm{Ca}^{2+}$ ions in a single site made up of two loops, each of which is bounded by a pair of $\beta$ strands. One pair of $\beta$-strands comes from one edge of the jelly-roll $\beta$-sandwich while the other pair is derived from the $\mathrm{N}$-terminal extension ${ }^{24}$ (Fig. 2a). The $\mathrm{Ca}^{2+}$ ions are both surrounded by seven oxygen ligands (Fig. 2a) derived from side-chain and main-chain functional groups from residues E899, E901, N903, D904, S922, D927, R929, and D930. Interestingly, in the absence of $\mathrm{Ca}^{2+}$, the $\mathrm{N}$-terminal $\beta$-strand and its associated loop (containing the first four of the above residues) rotates almost $180^{\circ}$ and adopts an $\alpha$-helical conformation in the crystal structure of the isolated domain ${ }^{24}$. Though the structure of full-length ColG has not been determined, these observations suggest that $\mathrm{Ca}^{2+}$ binding to ColG may be associated with a significant structural rearrangement ${ }^{24}$.

We therefore analyzed the superposition of the LipL32 $21-272$ and ColG collagen binding domain structures to determine if LipL32 $21-272$ could present a similar $\mathrm{Ca}^{2+}$ binding site. Figure $2 \mathrm{a}$ shows that the loop between $\beta 3$ and $\beta 5$ (that contains the short $\beta 4$ strand) in LipL32 $21-272$ corresponds well with one of the ColG $\mathrm{Ca}^{2+}$-binding loops. LipL32 $21-272$ also has a $\beta$-strand $(\beta 7)$ that superposes 
well with the $\mathrm{N}$-terminal $\beta$-strand of ColG, though these strands are not topologically equivalent. However, after $\beta 7$, the LipL32 $21-272$ polypeptide chain veers in a direction opposite to that observed in ColG, the result being that LipL32 $21-272$ does not present a structure that completely superposes with the Nterminal $\mathrm{Ca}^{2+}$-binding loop of ColG (Fig. 2).

We then analyzed this region of the LipL32 $21-272$ surface to see if it could present functional groups which could be poised to bind a divalent cation. Figure $2 \mathrm{~b}$ shows that LipL32 $21-272$ residues Y59, Y62, Q67, A68, D70, Y81, S114, and S247 all present side chain or main chain oxygens that line a cavity that superposes with the ColG $\mathrm{Ca}^{2+}$-binding site. This cavity has an approximate diameter of $8 \AA$ however, significantly greater than the $5 \AA$ oxygenoxygen distances observed in $\mathrm{Ca}^{2+}$-ColG structure. Small adjustments in side chain and main chain torsion angles could bring these oxygen atoms in closer proximity. We note that only one of the residues in this putative $\mathrm{Ca}^{2+}$-binding site is negatively charged, suggesting that it would be able to accommodate only one $\mathrm{Ca}^{2+}$ ion. Another curious feature of this cavity is the presence of a region of significant electron density which extended from the S114 side chains of both monomers (Fig 2c). This density could not be satisfactorily modeled as water molecules nor as a spherically symmetric $\mathrm{Ca}^{2+}$ ion $\left(\mathrm{Ca}^{2+}\right.$ was not included in the crystallization solution). The most satisfactory interpretation of the electron density was achieved by the insertion of an oxalate ion. After refinement, this oxalate positioned as to make clear hydrogen-bond contacts with Y59, Y62, Q67 and S114 (Fig. 2c). If this oxalate ion in fact co-purified with LipL32, it could contribute to the $\mathrm{Ca}^{2+}$-binding site by providing not only two oxygen ligands but also a second neutralizing negative charge. Another 
possibility is that this electron density is due to an immobilized portion of a citrate ion, present at $1.4 \mathrm{M}$ in the crystal mother liquor. Coincidentally or not, leptospires colonizes the free surfaces of renal proximal tubular epithelial cells from the kidney, locally and potentially enriched in oxalic acid and calcium ions $^{28}$. Physiologically, oxalate is removed from the body almost exclusively by filtration at the renal glomerulus and by secretion in the early portions of the proximal tubules. Kidney is well known for the production of oxalate and its level can exceed those of blood. Decreased renal clearance, local oxalate overproduction or accumulation may cause supersaturation, leading to the formation of local calcium oxalate crystals ${ }^{29}$.

\section{LipL32 $21-272$ specifically binds calcium ions.}

The above observations led us to test whether LipL32 $21-272$ is capable of interacting with calcium ions. We therefore used circular dichroism and fluorescence spectroscopy to detect structural changes in LipL32 $21-272$ induced by the addition of calcium ions. Circular dichroism spectra of LipL32 $21-272$ clearly demonstrate a change in secondary structure content upon the addition of $\mathrm{Ca}^{2+}$ but not upon the addition of $\mathrm{Mg}^{2+}$ (Fig. 3a). Consistent with this interpretation, in fluorescence spectroscopy experiments, a significant blue-shift in the LipL32 21 272 tryptophan emission was observed upon the addition of $1 \mathrm{mM} \mathrm{CaCl} 2$ but not upon addition of $1 \mathrm{mM} \mathrm{MgCl}$ (Fig. 3b). LipL3221-272 possesses three tryptophan residues, Trp85, Trp130 and Trp134 all of which are significantly buried within the LipL32 $21-272$ structure. Furthermore, the fluorescence of 1-amino-2-naphthol4-sulfonic acid (ANS) was observed to increase upon the addition of $\mathrm{Ca}^{2+}$ (Fig. $3 c$ ), indicating an overall structural change with an increase in the surface 
hydrophobicity of the LipL32 $21-272$ molecule. We also tested the ability of LipL32 $21-272$ to bind $\mathrm{Zn}^{2+}$ and $\mathrm{Cu}^{2+}$ ions but we did not observe any significant changes in the $C D$ or intrinsic fluorescence spectra (data not shown).

\section{Calcium binding by LipL32 $21-272$ increases protein stability.}

We then tested whether the addition of $\mathrm{Ca}^{2+}$ affected the conformational stability of LipL32 21-272. CD and ANS fluorescence were monitored during thermal denaturation of the protein in the presence or absence of $\mathrm{Ca}^{2+}$ (Fig. 3d and e respectively). In the $\mathrm{CD}$ experiments, the midpoint of the conformational transition $(\mathrm{Tm})$ was observed to increase from $50^{\circ} \mathrm{C}$ in the absence of $\mathrm{Ca}^{2+}$ to $56^{\circ} \mathrm{C}$ in the presence of $\mathrm{Ca}^{2+}$ while only a very small change in the $\operatorname{Tm}\left(+1^{\circ} \mathrm{C}\right)$ was observed upon addition of $\mathrm{MgCl}_{2}$ (Fig. 3d). A similar result was obtained by monitoring ANS fluorescence: in the presence or absence of $\mathrm{Mg}^{2+}$ the $\mathrm{Tm}$ was $51^{\circ} \mathrm{C}$ while in the presence of $\mathrm{Ca}^{2+}$ it increased to $58^{\circ} \mathrm{C}$ (Fig. $3 \mathrm{e}$ and data not shown). Finally, we did not observe any change in CD spectra, fluorescence spectra or thermal stability in the presence of $1 \mathrm{mM} \mathrm{ZnCl}_{2}$ or $\mathrm{CuCl}_{2}$ (data not shown).

One putative $\mathrm{Ca}^{2+}$-binding sites in LipL32 has been discussed above (Fig. 2a,b,c). Another possible site corresponds to the loop between $\alpha 3$ and $\beta 9$ that contains seven aspartate residues within an eight amino acid stretch (residues 161-168) (Fig. 2d). A portion of this loop containing the first three aspartates (residues 161-168) are absent in our crystal structure due to lack of electron density. Two more acidic residues within $\beta 9, \mathrm{E} 172$ and E173, are also near this loop (Fig. 2d). This region of the molecule is therefore also a potential 
$\mathrm{Ca}^{2+}$-binding site which could adopt a more ordered structure upon ligand binding.

\section{A putative polypeptide binding groove on the LipL32 $21-272$ surface}

The first of the two putative $\mathrm{Ca}^{2+}$-binding sites described above (Fig. 2a,b) lies above a hydrophobic pocket lined by the side-chains of residues V63, Y80, F214 and F226. This hydrophobic pocket is found in the middle of a deep groove that extends over half the circumference of the monomer surface (Fig 4a). While the bottom of the groove to one side of the hydrophobic pocket is also lined with hydrophobic side chains (Y59, W85, P97, P243, L244, I245), the other branch of the groove is lined with hydrophilic side chains (Y81, R136, E138, Y170, E172, R211, S213). Furthermore, both branches of this groove are exposed to solvent in the possible dimeric and polymeric structures that are suggested by the observed contacts in the LipL32 $21-272$ crystal (Supplementary Information Figure S1a).

These grooves have features that could indicate their involvement in binding to polypeptides. LipL32 $21-272$ has been shown to bind to extracellular matrix proteins such as collagen, fibronectin and laminin ${ }^{6 ; 17}$ and ColG of course binds collagen. While the collagen-binding domain of ColG has not been crystallized bound to its substrate, mutational analysis and computational docking studies have identified seven ColG residues that may mediate its interactions with collagen and are in the vicinity of the ColG $\mathrm{Ca}^{2+}$-binding site ${ }^{24}$. These residues are highlighted in Fig. $4 \mathrm{~b}$ and lie on the same face of the $\beta$ sandwich as do the LipL32 $21-272$ residues that contribute to the hydrophilic branch of the putative polypeptide-binding groove mentioned above (compare 
Fig. 4b with the right-most LipL32 $21-272$ structure in Fig 4a). As already mentioned, these grooves are all highly exposed in the possible dimeric and oligomeric structures that are suggested by the observed contacts in the LipL32 $21-272$ crystal (Fig. S1a). Therefore, if these grooves meditate LipL32 $21-272$ binding to collagens or to other extracellular matrix proteins, its dimerization or oligomerization on the bacterial surface would not impede these interactions and could instead provide a mechanism by which it increases the local concentration of ECM protein binding sites.

\section{Other possible polypeptide interacting sites on the LipL32 $21-272$ surface}

Besides the presence of the putative polypeptide binding groove on the LipL32 $21-272$ surface, it is also possible the presence of other domains in the LipL32 $21-272$ structure that could mediate interactions with other polypeptides. For instance, the presence of the acidic loop between $\alpha 3$ and $\beta 9$ (residues 154169, AKPVQKLDDDDDGDD, Figs. 1b, 2d and 5a) could mediate the binding to positively-charged ligand domains. Although in principle this region could be involved in the binding to laminin ${ }^{6}$ or plasma fibronectin ${ }^{17}$ (both proteins present positively charged domains that binds to negatively charged molecules like heparin/heparan sulfate), experimental data suggest that this is not the case and that the binding to these ligands instead involves the C-terminal segment of LipL32 molecule. Recombinant LipL32 $201-272$, corresponding to the last 72 LipL32 residues was shown to be able to interact to laminin $^{6}$ whereas recombinant LipL32 ${ }_{185-272}$ was shown to interact to plasma fibronectin and collagen $\mathrm{IV}^{17}$. These results imply that a putative interaction site resides in the segment between amino acids $185 / 201$ and 272 of LipL32. Of this region of the 
protein, residues 263-272 seem to be disordered since no corresponding electron density was observed in the electron density map. Also, the region comprising residues $185-243$ correspond to secondary structure elements $3_{10} 1$, $3_{10} 2, \beta 11$ and $\beta 12$. As $\beta 11$ and $\beta 12$ do not interact with each other within the $\beta$ sandwich, it is difficult to imagine how these sections of the molecule could fold correctly in the context of a C-terminal LipL32 fragment. However, residues 244-262 make up the $\alpha 4$ and $\beta 13$ motifs that interact with each other within the LipL32 structure and could possible remain folded in a Lipl32 C-terminal fragment. This motif is highly exposed in the LipL32 $21-272$ structure and is located contiguous to the putative polypeptide binding groove (the exposed surface immediately below the colored sections in the middle of Fig 2a).

\section{Conserved residues in LipL32 homologs points to functionally important regions of the protein.}

LipL32 proteins from Leptospira species are highly similar ( $\geq 95 \%$ identity, results not shown). The only significant variability that can be observed in LipL32 sequences from several dozen species is the length of the C-terminal extensions beyond the last helix $(\alpha 4)$. We can therefore propose that this unstructured region is not required for LipL32 function. A Blast search on the sequence databanks revealed that only three other bacterial proteins present significant similarity to LipL32: gi|88860771| from Pseudoalteromonas tunicata D2, originally isolated from the marine tunicate Ciona intestinalis (43\% identical), gi|149911212| from Moritella sp. PE36, a deep-sea piezophile heterotroph, adapted to high pressure (34\% identical), and gi|149370508| from an unidentified eubactérium SCB49 (35\% identical). Though all have been 
named LipL32, only that from $P$. tunicata has been shown to be functionally similar to its Leptospira orthologs ${ }^{6}$. An alignment of these sequences is shown in Fig. 5a. A few observations may be made from this alignment. Firstly, the acidic nature of the loop between $\alpha 3$ and $\beta 9$ in the Leptospira protein is maintained in the Pseudoalteromonas tunicata protein but is significantly reduced in LipL32 from other species (Fig 5a). This suggests that the role this loop plays in LipL32 function may differ across species. Secondly, some of these absolutely conserved residues cluster to form two extensive patches on the LipL32 $21-272$ surface (Fig $5 \mathrm{~b}$ ). One of these patches includes residues that lie at the interface between LipL32 $21-272$ monomers in the asymmetric unit (P52, S99, P100, F131, Y178, N179 and F226). This may indicate a possible physiological role for monomer-monomer interactions across this interface. The other surface patch of conserved residues corresponds very well to the central portion of the putative polypeptide binding groove described above (Figs. 5b). This same patch also includes four of the residues putatively involved in $\mathrm{Ca}^{2+}$ binding (Y59, Y62, D70, Y81).

\section{Final Considerations}

The importance of calcium as a key regulator in several fundamental aspects of eukaryote biology is well established. An increasing importance for a role for calcium in prokaryotes is also being implicated in several processes, including signal transduction ${ }^{30}$, cell cycle and division control ${ }^{31}$, competence ${ }^{32}$, pathogenesis ${ }^{33}$, motility and chemotaxis ${ }^{34 ; 35}$, host-pathogen interactions ${ }^{36 ; 37}$, stability and integrity of the outer lipopolysaccharide layer and bacterial cell wall $^{38}$ and specific enzyme activity ${ }^{39 ; 40 ; 41}$ (for review see ${ }^{42 ; 43 ; 44 ; 45}$ ). Calcium 
ions are absolutely required for Leptospira spp to grow and survive ${ }^{46 ; 47}$. Interestingly, calcium chloride, zinc chloride, or copper chloride have been described as necessary to enhance the stability of LipL32 during its extraction from the outer membrane ${ }^{3 ; 4}$.

Our data strongly indicate that LipL32 binds $\mathrm{Ca}^{2+}$. The data also suggest that LipL32 does not bind $\mathrm{Mg}^{2+}, \mathrm{Zn}^{2+}$ or $\mathrm{Cu}^{2+}$ ions, at least not in a manner similar to that observed for $\mathrm{Ca}^{2+}$, since no significant structural changes or increases in thermal stability were observed in these cases. Several calciumbinding motifs in bacterial proteins have already been identified, such as EFhand domains ${ }^{42}$, leukotoxin ${ }^{48}$, RTX-toxin domains ${ }^{49 ;}$ 50, Greek key motif observed in $\beta y$ crystallins ${ }^{51}$, and some jelly roll fold proteins ${ }^{24}$ and putative orphan motifs rich in oxygen atoms provided by negatively charged glutamate or aspartate ${ }^{42}$. Two putative $\mathrm{Ca}^{2+}$-binding sites in LipL32 have been discussed above (Fig. 2). One is located above the central part of the putative polypeptidebinding groove and superposes with the $\mathrm{Ca}^{2+}$-binding site of ColG (Fig. 2a). The other corresponds to the loop between $\alpha 3$ and $\beta 9$ that contains seven aspartate residues within an eight amino acid stretch (residues 161-168) as well as two glutamate residues within $\beta 9$ (Fig. 2 d). A large part of this loop is either poorly defined or absent in our crystal structure. However, this loop is located precisely at the end of the hydrophilic branch of the putative polypeptide-binding groove, suggesting that it may be involved in this function. Recently, LigB, a member of an important family of leptospiral proteins possessing bacterial immunoglobulinlike (Blg) domains (also found in LigA), was also shown to bind calcium ions ${ }^{52}$. Both LigA and LigB present the Blg domains consisting of 90 amino acid tandem repeats. These proteins have identical $\mathrm{N}$-terminal sequences but the $\mathrm{C}$ - 
termini are variable ${ }^{53 ; 54 ; 55}$, LigB presenting a C-terminal extension. Like LipL32, LigA and LigB interact with extracellular matrix components fibronectin, fibrinogen, laminin and collagen ${ }^{56 ; 57 ; 58}$. Although, the calcium binding motif was not absolutely identified in LigB, it has been suggested that it may adopt a $\mathrm{Ca}^{2+}{ }_{-}$ binding Greek key motif observed in $\beta y$ crystallins ${ }^{52}$ and seems to be distinct from those possible calcium binding sites for LipL32 described here.

Hoke et al ${ }^{6}$ and Hauk et al ${ }^{17}$ showed that the C-terminal portion of the LipL32 molecule (amino acids 185/201 to 272 ) is sufficient to mediate binding to different ECM proteins. Of these residues, only those corresponding to $\beta 13$ and $\alpha 4$ form secondary structures that could be expected to associate with one another in a native-like manner. Besides this region, we have also described other possible polypeptide interacting regions, one involving a clusters of acidic residues between $\alpha 3$ and $\beta 9$ and the other, a groove that crosses one face of the LipL32 surface and contains several absolutely conserved residues in LipL32 homologs. These observations suggest that LipL32 may possess more than one site that mediates its interactions with several different host proteins (collagens, plasma fibronectin, and laminin) ${ }^{6 ; 17}$. The crystal structure of this important leptospiral protein has provided a wealth of information from which to raise hypothesis regarding the molecular mechanisms by which LipL32 interacts with $\mathrm{Ca}^{2+}$ and with ECM proteins. These hypotheses will be addressed in future experimental studies using site-directed LipL32 mutants. 


\section{MATERIALS AND METHODS}

\section{LipL32 expression and purification}

The following primers were used to amplify a $L$. interrogans sorovar Copenhageni fragment coding for residues 21-272, preceeded by an initiation methionine: 5'-CTCGAGCATATGGGTGCTTTCGGTGGTCTG-3' and 5'AAGCTTACTTAGTCGCGTCACCTAATCCTCCA-3'. The amplified product was cloned into pGEM-T Easy vector (Promega) and then into the pAE expression vector ${ }^{59}$ as described ${ }^{60}$. Selenomethionine-containing LipL32 $21-272$ was expressed in E. coli strain BL21 SI (Gibco/BRL, ${ }^{61}$ ) as described ${ }^{60}$. Cells from 1 I culture were collected by centrifugation, resuspended in $100 \mathrm{ml}$ of $20 \mathrm{mM}$ triethalolamine $\mathrm{pH}$ 7.8 and lysed in a French press (Thermo Spectronic). The soluble and insoluble fractions were isolated by centrifugation at $8,400 \times \mathrm{g}$ for $10 \mathrm{~min}$. Purification of Selenomethionine LipL32 $21-272$ proceeded in three steps as follows. The soluble fraction was applied onto a column (1-cm diameter) containing $5 \mathrm{ml}$ of QSepharose Fast Flow resin (GE HealthCare) equilibrated with $20 \mathrm{mM}$ triethanolamine $\mathrm{pH}$ 7.8. The unbound fraction containing LipL32 $21-272$ was then applied to a column of similar dimensions containing SP-Sepharose Fast Flow resin (GE HealthCare). The resin was washed with 10 column volumes of $20 \mathrm{mM}$ triethanolamine $\mathrm{pH} 7.8$ containing $0.1,0.3,0.5,0.7$ and $1 \mathrm{M} \mathrm{NaCl}$. Fractions containing LipL32 $21-272$ were pooled, $\mathrm{NaCl}$ was added to a final concentration of $3 \mathrm{M}$ and this mixture was then added to a Phenyl-Sepharose Fast Flow column (GE HealthCare) previously equilibrated with $20 \mathrm{mM}$ triethanolamine $\mathrm{pH} 7.8$ and 3 $\mathrm{M} \mathrm{NaCl}$. LipL32 $21-272$ was eluted using a decreasing $2.5-0 \mathrm{M} \mathrm{NaCl}$ gradient in 20 
$\mathrm{mM}$ trietanolamine $\mathrm{pH}$ 7.8. Fractions containing LipL32 $21-272$ were dialyzed in three steps with 2 liters of $20 \mathrm{mM}$ trietanolamine $\mathrm{pH} 7.8$ and concentrated using an Amicon ultrafiltration system with a $10 \mathrm{kDa}$ cut-off membrane.

\section{Protein decalcification}

For calcium binding studies, proteins were decalcified as previously described ${ }^{52}$. Briefly, proteins were incubated for 60 minutes at $25^{\circ} \mathrm{C}$ in $3 \mathrm{mM}$ EDTA followed by buffer exchange with Chelating Sepharose-treated Tris buffer. All buffer solutions used for calcium binding studies were passed through Chelating Sepharose resin and stored in plasticwares.

\section{Spectroscopic and protein stability studies}

CD measurements were carried out on a J-810 Circular Dichroism Spectropolarimeter (Jasco Inc.) coupled to a Peltier Jasco PFD-425S system for temperature control. Far-UV spectra were recorded in the spectral range $195-260 \mathrm{~nm}$ and averaged over ten scans at $20^{\circ} \mathrm{C}$, using a $1 \mathrm{~mm}$ path length quartz cell, $0.5 \mathrm{~nm}$ step resolution, $50 \mathrm{~nm} / \mathrm{min}$ speed, $8 \mathrm{~s}$ response time, and 1 $\mathrm{nm}$ bandwidth. Protein concentration was $10 \mu \mathrm{M}$ in $10 \mathrm{mM}$ Tris- $\mathrm{Cl}, \mathrm{pH} 8.0,50$ $\mathrm{mM} \mathrm{KCl}$ and either $1 \mathrm{mM} \mathrm{MgCl}_{2}, 1 \mathrm{mM} \mathrm{CaCl}_{2}, 1 \mathrm{mM} \mathrm{ZnSO}_{4}$ or $1 \mathrm{mM} \mathrm{CuCl}_{2}$. Spectral correction was performed by subtracting the blank. The measured ellipticity, $\theta$ (mdegree), was converted to molar ellipticity, [ $\theta]$ (degree $\mathrm{cm}^{2} \mathrm{dmol}^{-}$ $\left.{ }^{1}\right)$. For thermal unfolding studies, change in the secondary structure was followed by measuring [ $\theta$ ] at $216 \mathrm{~nm}$ at temperatures between $30{ }^{\circ} \mathrm{C}$ and $70{ }^{\circ} \mathrm{C}$ at $2{ }^{\circ} \mathrm{C}$ steps. Fluorescence spectroscopy studies were carried out on an Aviv ATF105 Fluorimeter using a $1 \mathrm{~mm}$ path length quartz cell, $1 \mathrm{~nm}$ excitation 
bandwidth and $10 \mathrm{~nm}$ emission bandwidth. Protein concentration was $2 \mu \mathrm{M}$ in $10 \mathrm{mM}$ Tris- $\mathrm{Cl}, \mathrm{pH} 8.0,50 \mathrm{mM} \mathrm{KCl}$ and either $1 \mathrm{mM} \mathrm{MgCl}, 1 \mathrm{mM} \mathrm{CaCl}, 1 \mathrm{mM}$ $\mathrm{ZnSO}_{4}$ or $1 \mathrm{mM} \mathrm{CuCl}_{2}$. Intrinsic tryptophan fluorescence was measured with an excitation wavelength set at $285 \mathrm{~nm}$ and emission spectra were recorded in the spectral range $310-400 \mathrm{~nm}{ }^{62}$. Alternatively, thermal unfolding studies were carried out in the presence of $8 \mu \mathrm{M}$ 1-amino-2-naphthol-4-sulfonic acid (ANS). The temperature range tested was between $20^{\circ} \mathrm{C}$ and $70^{\circ} \mathrm{C}$. The change in the secondary structure was followed by measuring ANS fluorescence at $470 \mathrm{~nm}$ with an excitation wavelength of $380 \mathrm{~nm}^{52}$. In both circular dichroism and fluorescence thermal denaturation experiments the fraction of folded protein was calculated by using the pre-transition and post-transition baselines to calculate the fractional change in signal at each temperature point and assuming that the $C D$ and fluorescence signals of the folded and unfolded states are linear functions of temperature in the transition region ${ }^{63}$.

\section{LipL32 $21-272$ structure determination}

LipL32 $21-272$ containing selenomethionione was crystallized as described elsewhere and datasets from two crystals were collected ${ }^{60}$. A multiple wavelength anomalous dispersion (MAD) data set was collected using one crystal at two wavelengths, 0.97814 and $0.978308 \AA$, corresponding to the peak and infection points of the fluorescence spectrum, respectively. This crystal diffracted to $2.93 \AA$, though data collected up to $2.6 \AA$ was used for phase determination and for initial LipL32 initial model building. The program SHELXD ${ }^{64}$ was used to find 12 selenium sites in the asymmetric unit. Se positions were subsequently refined and phases were calculated up to $2.6 \AA$ 
resolution using the program SHARP ${ }^{65}$. Phases were refined by density modification using the programs SOLOMON ${ }^{66}$ and $\mathrm{DM}^{67 ; 68}$. The resulting electron-density map was used to construct a preliminary polyalanine model using the program ARP/WARP ${ }^{69}$ that contained 303 residues distributed over 27 peptide segments. Interpretation of electron-density maps and construction of missing residues was performed using the program COOT ${ }^{70}$. Subsequently, a second dataset was collected from a new crystal (crystal 2 in Hauk et a ${ }^{60}$ ) that diffracted at $2.25 \AA$ resolution using $1.459 \AA$ radiation ${ }^{60}$. The initial model was used to calculate phases for the $2.25 \AA$ resolution dataset using the Phaser program $^{67 ;} 71$. Structural refinement of the LipL32 model was done using ARP/WARP ${ }^{69}$, REFMAC $^{72}, \mathrm{CNS}^{73}$, and $\mathrm{COOT}^{70}$. TLS was used in the final cycles of refinement with each chain in the asymmetric unit divided into 15 independent group segments ${ }^{74}$. Water molecules were added with ARP/WARP, REFMAC, and directly by COOT. The final Rwork, Rfree and FOM values are $0.184,0.227$ and 0.839 , respectively. $91.5 \%$ of the residues are in the most favored regions and $8.5 \%$ are in additionally allowed regions in the Ramachandran plot. The refinement data statistics are shown in Table 2. The coordinates of final LipL32 $21-272$ model have been deposited in the Protein database with accession code 3FRL. 


\section{TABLES}

Table 1: Refinement statistics for $\mathbf{P} 3_{2} 21$ LipL32 ${ }_{21-272}$ crystal structure.

\begin{tabular}{lc}
\hline Refinement $(\mathbf{3 5 . 0}-\mathbf{2 . 2 5} \AA$ ) & \\
\hline No. of molecules/A.U. & 2 \\
$\quad$ residues/chain & 254 \\
$\quad$ waters & 295 \\
$\mathrm{R}_{\text {factor }}{ }^{\top}$ & 0.184 \\
$\mathrm{R}_{\text {free }}{ }^{\top}$ & 0.227 \\
R.m.s.d. $^{\text {bond lengths }(\AA)}$ & \\
$\quad$ bond angles $\left({ }^{\circ}\right)$ & 0.017 \\
$\%$ of residues in Ramachandran regions: & 1.582 \\
most favored & \\
additional allowed & 91.5 \\
generously allowed & 8.5 \\
disallowed & 0.0 \\
\hline
\end{tabular}

${ }^{\top} \mathbf{R}_{\text {factor }}=\Sigma\left|F_{O}-F_{C}\right| / \Sigma F_{O}$

$5 \%$ of the data were excluded for $R_{\text {free }}$ calculation. 
Table 2. Proteins structurally similar to LipL32 $21-272$ identified using the Dali server ${ }^{21}$.

\begin{tabular}{|c|c|c|c|c|}
\hline Z-score & RMSD (Å) & PDB & Protein & Organism \\
\hline $8.8-6.7$ & $3.2-4.9$ & $\begin{array}{c}\text { 2QFE, 1KFU, 1QXP, 1U5I, 1DF0, } \\
\text { 1KFX, 3BOW, 3DFO, 1KFX, }\end{array}$ & calpain-7, calpain-2 & Homo sapiens, Rattus norvegicus \\
\hline 6.3 & 3.1 & 1PM4 & Y.p.-derived mitogen a & Yersinia pseudotuberculosis \\
\hline 5.4 & 2.4 & 2QUO & C. perfringens enterotoxin & Clostridium perfringens \\
\hline $6.3-5.8$ & 2.4 & 1NQJ, 1NQD, $2 \mathrm{O} 8 \mathrm{O}$ & class 1 collagenase & Clostridium histolyticum \\
\hline $5.9-5.0$ & $3.2-4.0$ & 1F15, 1LAJ, 1ZA7, 1GFF, 1WCD & $\begin{array}{lll}\text { lcosahedral } & \text { RNA } & \text { virus } \\
\text { coat proteins } & & \end{array}$ & $\begin{array}{l}\text { Cucumber mosaic vírus, Tomato asp. virus, } \\
\text { Cowpea c. m. virus, Bacteriophage g4, } \\
\text { Avian inf. B. d. virus }\end{array}$ \\
\hline $5.3-5.2$ & 4.2 & 2ID4, 1R64, 1OT5 & kexin2 peptidase & Saccharomyces cerevisiae \\
\hline
\end{tabular}

* All Dali server hits with Z-score > 5.0 are listed. 


\section{FIGURE LEGENDS}

Figure 1. LipL32 21-272 structure and crystal contacts. (a) Cartoon model of the LipL32 $21-272$ monomer. The $\mathrm{N}$ - and C-termini are indicated. $\beta$-strands, $\alpha$ helices and $3_{10}$ helicies are numbered in the order in which they appear in the sequence. Helices are colored red, the eight $\beta$-strands that form the core jellyroll topology are shown in blue, while the other $\beta$-strands are show in yellow. (b) Topology diagram for LipL32 $21-272$ in which helices are represented as red rectangles and $\beta$-strands as arrows. (c) Cartoon model of the LipL32 $21-272$ dimer within the asymmetric unit. Monomers are related by a non-crystallographic twofold axis (vertical). Residues at the dimer interface (interface 1 in the text) are shown as sticks and are colored in yellow for the monomer at the left and cyan for the monomer at the right. (d) Interface between the $\mathrm{N}$-terminal $\beta$-hairpin structures observed between the two monomers in the asymmetric unit. This interface involves the side-chains of some hydrophobic as well as several hydrophilic residues (L35, S36, D38, 140, P41, V47, T49, L50, L51, P52). These residues are shown as stick models (only some are labeled with their residue number). Coloring is as in (c). (e) Cartoon model of a LipL32 $21-272$ dimer by a crystallographic two-fold axis (vertical). Residues at the dimer interface (interface 2 in the text) are shown as sticks and are colored in yellow for the monomer at the left and cyan for the monomer at the right. (f) Representative structures in the protein data bank that present significant structural similiarity to LipL32 21-272. All structures are colored as in (a) and are oriented so as to superpose with the LipL32 $21-272$ structure as shown in (a). 2QFE (Calpain-7, chain A) ${ }^{75}$, 1PM4 (YPMa toxin, chain $\left.A\right)^{76}, 2 \mathrm{QUO}$ (Heat-labile toxin, chain $\left.A\right)^{22}$, 1NQD (Class 1 collagenase, chain $A)^{24}, 1 \mathrm{ZA7}$ (Coat Protein, chain $\left.A\right)^{26}$ and 1R64 (Kexin2, residues 460-601, chain $A)^{77}$. Parts (a) and (c) to (f) of this figure were generated using $\mathrm{PyMOL}^{78}$. 
Figure 2. Possible $\mathrm{Ca}^{2+}$-binding sites in LipL32 21-272. (a) Superposition of LipL32 $21-272$ with the structure of the collagen binding domain of ColG (1nqd; ${ }^{24}$ ) at the ColG Ca ${ }^{2+}$-binding site. The two $\mathrm{Ca}^{2+}$-binding loops of $\mathrm{ColG}$ are shown as a dark blue cartoon with $\mathrm{Ca}^{2+}$-coordinating residues depicted with dark blue lines except for oxygen atoms which are red. The two $\mathrm{Ca}^{2+}$ ions are shown as two small green spheres. The LipL32 $21-272$ backbone is depicted as a green ribbon. Putative LipL32 21-272 $\mathrm{Ca}^{2+}$-binding residues are colored yellow, except for oxygen and nitrogen atoms which are colored red and blue respectively. (b) Depiction of the putative LipL32 $21-272 \mathrm{Ca}^{2+}$-binding cavity in which the solventexposed surfaces of candidate $\mathrm{Ca}^{2+}$-binding residues are depicted. An oxalate ion, modeled in the same position within the cavity of both monomers of the asymmetric unit is also shown. The LipL32 $21-272$ orientation is very similar to that in (a) and the coloring is the same. (c) 2Fo-Fc electron density map of a portion of the putative $\mathrm{Ca}^{2+}$-binding cavity contoured at $1.5 \sigma$. Distances compatible with hydrogen bonds involving the modeled oxalate ion are shown. (d) Cartoon depiction of the LipL3221-272 structure near the loop between $\alpha 3$ and $\beta 9$. The acidic sequence DDGDD (residues 164-168) is shown as orange sticks orange while the rest of the loop (residues 154-159 and residue 169) is shown as a blue ribbon. The gap in the loop corresponds to acidic residues 160-163 (LDDD) which are omitted from the model due to a lack of electron density. Nearby residues E172 and E173 within $\beta 9$ are depicted as red sticks. Parts (a), (b) and (d) were produced using PyMOL ${ }^{78}$; part (c) was produced using $\operatorname{Coot}^{70}$.

Figure 3. $\mathrm{Ca}^{2+}$-induced conformational and stability changes in LipL32 21 272. (a) Circular dichroism (CD) spectra of LipL3221-272 in the absence or presence of $\mathrm{Ca}^{2+}$ or $\mathrm{Mg}^{2+}$. $\mathrm{CD}$ experiments were performed with $10 \mu \mathrm{M}$ protein in $10 \mathrm{mM}$ Tris- $\mathrm{Cl} \mathrm{pH} 8.0,50 \mathrm{mM} \mathrm{KCl}$ in the presence or absence of either $1 \mathrm{mM}$ $\mathrm{CaCl}_{2}$ or $1 \mathrm{mM} \mathrm{MgCl}$. (b) LipL32 $21-272$ tryptophan fluorescence in the absence of divalent metals or in the presence of $\mathrm{Ca}^{2+}$ or $\mathrm{Mg}^{2+}$. A blue-shift in Trp emission is observed in the presence of $\mathrm{Ca}^{2+}$. Intrinsic fluorescence experiments were performed with $2 \mu \mathrm{M}$ protein in $10 \mathrm{mM}$ Tris-Cl pH 8.0, $50 \mathrm{mM}$ $\mathrm{KCl}$ in the presence or absence of either $1 \mathrm{mM} \mathrm{CaCl} 2$ or $1 \mathrm{mM} \mathrm{MgCl}$. Excitation 
wavelength was $285 \mathrm{~nm}$. (c) $\mathrm{Ca}^{2+}$-binding to LipL32 $21-272$ induces a change in ANS fluorescence. For these experiments, $8 \mu \mathrm{M}$ ANS was added to $2 \mu \mathrm{M}$ protein in $10 \mathrm{mM}$ Tris- $\mathrm{Cl} \mathrm{pH} \mathrm{8.0,50mM} \mathrm{KCl}$ in the presence or absence of $1 \mathrm{mM}$ $\mathrm{CaCl}_{2}$. Excitation wavelength was set at $380 \mathrm{~nm}$ and emission wavelength set at $470 \mathrm{~nm}$. (d) Thermal stability of LipL32 $21-272$ in different conditions. Circular dichroism was used to detect temperature-induced changes in LipL32 $21-272$ secondary structure (see Materials and Methods). Conditions were the same as in part (a). (e) The thermal stability of LipL32 $21-272$ in the presence of $\mathrm{Ca}^{2+}$ and $\mathrm{Mg}^{2+}$ was measured by monitoring changes in ANS fluorescence (see Materials and Methods). For this experiment, $8 \mathrm{mM}$ ANS were added to $2 \mu \mathrm{M}$ protein in $10 \mathrm{mM}$ Tris- $\mathrm{Cl} \mathrm{pH} \mathrm{8.0,50mM} \mathrm{KCl}$, in the presence of either $1 \mathrm{mM} \mathrm{MgCl} 2$ or $1 \mathrm{mM}$ $\mathrm{CaCl}_{2}$. When this experiment was performed in the absence of divalent metal ions, the thermal denaturation curve was essentially identical to that observed for LipL32 $21-272$ in the presence of $\mathrm{Mg}^{2+}$ (data not shown).

Figure 4. A putative polypeptide-binding groove in LipL32 21-272. (a) Surface depictions of LipL32 $21-272$ in which residues Y59, W85, P97, P243, L244, I245 are shown in blue, V63, Y80, F214 and F226 are shown in yellow, Y81, R136, E138, Y170, E172, R211, and S213 are shown in red and the rest is shown in green. The indicated residues line the bottom of a deep and continuous groove that runs along half the circumference of the LipL32 $21-272$ structure. The groove can be divided into a hydrophilic branch (red) and a hydrophobic branch (blue and yellow). The putative $\mathrm{Ca}^{2+}$-binding site depicted in Fig. 3 lies above the cavity depicted in yellow. The three views depicted are related by rotations of about $70^{\circ}$ each about a vertical axis. (b) Surface depiction of the collagenbinding domain of ColG in which seven residues that may mediate its interactions with collagen, identified by mutational analysis and computational docking ${ }^{24}$ are depicted in red. Of these, six occupy positions that correspond to residues in the hydrophilic branch of the groove depicted in part (a). The ColG structure is oriented as to be aligned with the LipL32 $21-272$ structure shown to the right in (a). The two bound $\mathrm{Ca}^{2+}$ ions are depicted as dark spheres in the top left corner of the ColG structure (arrow). Figures were produced using $\mathrm{PyMOL}^{78}$. 
Figure 5. Conserved residues in the LipL32 family map to the LipL32 $21-272$ asymmetric unit dimer interface and to the putative polypeptide groove and $\mathrm{Ca}^{2+}$-binding sites. (a) Sequence alignment of LipL32 proteins from Leptospira interrogans (gi|45657230|), Pseudoalteromonas tunicata (gi|88860771|), Moritella sp. (gi|149911212|) and unidentified eubacterium SCB49 (gi|149370508|). Secondary structure elements are indicated above the L. interrogans sequence. Absolutely conserved $\left({ }^{*}\right)$, highly similar $(:)$ and similar (.) residues are indicated below the alignment. The lipobox containing $\mathrm{C} 20$, the fatty acid acceptor, as well as the highly acidic stretch of amino acids between $\alpha 3$ and $\beta 9$ are boxed. The sequence of recombinant LipL32 $21-272$ begins at G21 and is preceded by an initiation methionine. Aligments were performed using the ClustalW program ${ }^{79}$ followed by manual adjustment. (b) Solvent-exposed surface of the LipL32 $21-272$ monomer in which residues absolutely conserved in LipL32 homologs are colored yellow (F214 and F226), red (Y81 and R211), blue (Y59, W85 and P87) or cyan (P52, S99, P100, F131, Y178, N179 and F226) All other absolutely conserved residues are shown in orange. Two views of the molecule are shown, related by an approximately $180^{\circ}$ rotation about the vertical axis, in order to depict the two largest solvent exposed surface patches of conserved residues. On the left, the orientation is similar to that shown in the middle of Fig. 4a and the largest patch of conserved residues corresponds to the putative polypeptide binding groove (colored blue, yellow or red as in Fig. 4a). On the right, some of conserved residues (cyan) are buried at the dimer interface in the asymmetric unit (interface 1, Fig 1c). Non-conserved surface residues are shown in green. Figures were produced using $\mathrm{PyMOL}^{78}$. 


\section{REFERENCES}

1. McBride, A. J., Athanazio, D. A., Reis, M. G. \& Ko, A. I. (2005). Leptospirosis. Curr Opin Infect Dis 18, 376-86.

2. Palaniappan, R. U., Ramanujam, S. \& Chang, Y. F. (2007). Leptospirosis: pathogenesis, immunity, and diagnosis. Curr Opin Infect Dis 20, 284-92.

3. Zuerner, R. L., Knudtson, W., Bolin, C. A. \& Trueba, G. (1991). Characterization of outer membrane and secreted proteins of Leptospira interrogans serovar pomona. Microb Pathog 10, 311-22.

4. Haake, D. A., Chao, G., Zuerner, R. L., Barnett, J. K., Barnett, D., Mazel, M., Matsunaga, J., Levett, P. N. \& Bolin, C. A. (2000). The leptospiral major outer membrane protein LipL32 is a lipoprotein expressed during mammalian infection. Infect Immun 68, 2276-85.

5. Picardeau, M., Bulach, D. M., Bouchier, C., Zuerner, R. L., Zidane, N., Wilson, P. J., Creno, S., Kuczek, E. S., Bommezzadri, S., Davis, J. C., McGrath, A., Johnson, M. J., Boursaux-Eude, C., Seemann, T., Rouy, Z., Coppel, R. L., Rood, J. I., Lajus, A., Davies, J. K., Medigue, C. \& Adler, B. (2008). Genome sequence of the saprophyte Leptospira biflexa provides insights into the evolution of Leptospira and the pathogenesis of leptospirosis. PLoS ONE 3, e1607.

6. Hoke, D. E., Egan, S., Cullen, P. A. \& Adler, B. (2008). LipL32 is an extracellular matrix-interacting protein of Leptospira spp. and Pseudoalteromonas tunicata. Infect Immun 76, 2063-9.

7. Cullen, P. A., Cordwell, S. J., Bulach, D. M., Haake, D. A. \& Adler, B. (2002). Global analysis of outer membrane proteins from Leptospira interrogans serovar Lai. Infect Immun 70, 2311-8.

8. Cullen, P. A., Xu, X., Matsunaga, J., Sanchez, Y., Ko, A. I., Haake, D. A. \& Adler, B. (2005). Surfaceome of Leptospira spp. Infect Immun 73, 4853-63.

9. Guerreiro, H., Croda, J., Flannery, B., Mazel, M., Matsunaga, J., Galvao Reis, M., Levett, P. N., Ko, A. I. \& Haake, D. A. (2001). Leptospiral proteins recognized during the humoral immune response to leptospirosis in humans. Infect Immun 69, 4958-68.

10. Haake, D. A. (2000). Spirochaetal lipoproteins and pathogenesis. Microbiology 146 ( Pt 7), 1491-504.

11. Branger, C., Chatrenet, B., Gauvrit, A., Aviat, F., Aubert, A., Bach, J. M. \& Andre-Fontaine, G. (2005). Protection against Leptospira interrogans sensu lato challenge by DNA immunization with the gene encoding hemolysin-associated protein 1. Infect Immun 73, 4062-9.

12. Branger, C., Sonrier, C., Chatrenet, B., Klonjkowski, B., Ruvoen-Clouet, N., Aubert, A., Andre-Fontaine, G. \& Eloit, M. (2001). Identification of the hemolysis-associated protein 1 as a cross-protective immunogen of Leptospira interrogans by adenovirus-mediated vaccination. Infect Immun 69, 6831-8.

13. Seixas, F. K., da Silva, E. F., Hartwig, D. D., Cerqueira, G. M., Amaral, M., Fagundes, M. Q., Dossa, R. G. \& Dellagostin, O. A. (2007).

Recombinant Mycobacterium bovis BCG expressing the LipL32 antigen 
of Leptospira interrogans protects hamsters from challenge. Vaccine 26, 88-95.

14. Flannery, B., Costa, D., Carvalho, F. P., Guerreiro, H., Matsunaga, J., Da Silva, E. D., Ferreira, A. G., Riley, L. W., Reis, M. G., Haake, D. A. \& Ko, A. I. (2001). Evaluation of recombinant Leptospira antigen-based enzyme-linked immunosorbent assays for the serodiagnosis of leptospirosis. J Clin Microbiol 39, 3303-10.

15. Bomfim, M. R., Ko, A. \& Koury, M. C. (2005). Evaluation of the recombinant LipL32 in enzyme-linked immunosorbent assay for the serodiagnosis of bovine leptospirosis. Vet Microbiol 109, 89-94.

16. Dey, S., Mohan, C. M., Kumar, T. M., Ramadass, P., Nainar, A. M. \& Nachimuthu, K. (2004). Recombinant LipL32 antigen-based single serum dilution ELISA for detection of canine leptospirosis. Vet Microbiol 103, 99-106.

17. Hauk, P., Macedo, F., Romero, E. C., Vasconcellos, S. A., de Morais, Z. M., Barbosa, A. S. \& Ho, P. L. (2008). In LipL32, the major leptospiral lipoprotein, the $\mathrm{C}$ terminus is the primary immunogenic domain and mediates interaction with collagen IV and plasma fibronectin. Infect Immun 76, 2642-50.

18. Murray, G. L., Srikram, A., Hoke, D. E., Wunder, E. A., Jr., Henry, R., Lo, M., Zhang, K., Sermswan, R. W., Ko, A. I. \& Adler, B. (2008). The major surface protein LipL32 is not required for either acute or chronic infection with Leptospira interrogans. Infect Immun.

19. Hauk, P., Guzzo, C.R., Ho, P.L., Farah, C.S. (2009). Crystallization and preliminary X-ray analysis of LipL32 from Leptospira interrogans sorovar Copenhageni. submitted.

20. Krissinel, E. \& Henrick, K. (2007). Inference of macromolecular assemblies from crystalline state. J Mol Biol 372, 774-97.

21. Holm, L., Kaariainen, S., Rosenstrom, P. \& Schenkel, A. (2008). Searching protein structure databases with DaliLite v.3. Bioinformatics 24, 2780-1.

22. Van Itallie, C. M., Betts, L., Smedley, J. G., 3rd, McClane, B. A. \& Anderson, J. M. (2008). Structure of the claudin-binding domain of Clostridium perfringens enterotoxin. J Biol Chem 283, 268-74.

23. Hanna, P. C., Mietzner, T. A., Schoolnik, G. K. \& McClane, B. A. (1991). Localization of the receptor-binding region of Clostridium perfringens enterotoxin utilizing cloned toxin fragments and synthetic peptides. The $30 \mathrm{C}$-terminal amino acids define a functional binding region. $\mathrm{J}$ Biol Chem 266, 11037-43.

24. Wilson, J. J., Matsushita, O., Okabe, A. \& Sakon, J. (2003). A bacterial collagen-binding domain with novel calcium-binding motif controls domain orientation. EMBO J 22, 1743-52.

25. Johnson, J. E. (2003). Virus particle dynamics. Adv Protein Chem 64, 197-218.

26. Speir, J. A., Bothner, B., Qu, C., Willits, D. A., Young, M. J. \& Johnson, J. E. (2006). Enhanced local symmetry interactions globally stabilize a mutant virus capsid that maintains infectivity and capsid dynamics. $J$ Virol 80, 3582-91. 
27. Tompa, P., Emori, Y., Sorimachi, H., Suzuki, K. \& Friedrich, P. (2001). Domain III of calpain is a ca2+-regulated phospholipid-binding domain. Biochem Biophys Res Commun 280, 1333-9.

28. Faine, S., Adler, B., Bolin, C., Perolat, P. (1999). Leptospira and Leptospirosis. Second Edition edit, MedSci., Melbourne.

29. Worcester, E. M., Nakagawa, Y., Bushinsky, D. A. \& Coe, F. L. (1986). Evidence that serum calcium oxalate supersaturation is a consequence of oxalate retention in patients with chronic renal failure. J Clin Invest 77, 1888-96.

30. Dominguez, D. C. (2004). Calcium signalling in bacteria. Mol Microbiol 54, 291-7.

31. Yu, X. C. \& Margolin, W. (1997). Ca2+-mediated GTP-dependent dynamic assembly of bacterial cell division protein FtsZ into asters and polymer networks in vitro. EMBO J 16, 5455-63.

32. Trombe, M. C., Rieux, V. \& Baille, F. (1994). Mutations which alter the kinetics of calcium transport alter the regulation of competence in Streptococcus pneumoniae. J Bacteriol 176, 1992-6.

33. Straley, S. C., Plano, G. V., Skrzypek, E., Haddix, P. L. \& Fields, K. A. (1993). Regulation by Ca2+ in the Yersinia low-Ca2+ response. Mol Microbiol 8, 1005-10.

34. Tisa, L. S. \& Adler, J. (1992). Calcium ions are involved in Escherichia coli chemotaxis. Proc Natl Acad Sci U S A 89, 11804-8.

35. Tisa, L. S. \& Adler, J. (1995). Cytoplasmic free-Ca2+ level rises with repellents and falls with attractants in Escherichia coli chemotaxis. Proc Natl Acad Sci U S A 92, 10777-81.

36. Dardanelli, M., Angelini, J. \& Fabra, A. (2003). A calcium-dependent bacterial surface protein is involved in the attachment of rhizobia to peanut roots. Can J Microbiol 49, 399-405.

37. Izutsu, K. T., Belton, C. M., Chan, A., Fatherazi, S., Kanter, J. P., Park, Y. \& Lamont, R. J. (1996). Involvement of calcium in interactions between gingival epithelial cells and Porphyromonas gingivalis. FEMS Microbiol Lett 144, 145-50.

38. Smith, R. J. (1995). Calcium and bacteria. Adv Microb Physiol 37, 83133.

39. Nardini, M., Lang, D. A., Liebeton, K., Jaeger, K. E. \& Dijkstra, B. W. (2000). Crystal structure of pseudomonas aeruginosa lipase in the open conformation. The prototype for family I.1 of bacterial lipases. $J$ Biol Chem 275, 31219-25.

40. Smith, C. A., Toogood, H. S., Baker, H. M., Daniel, R. M. \& Baker, E. N. (1999). Calcium-mediated thermostability in the subtilisin superfamily: the crystal structure of Bacillus Ak.1 protease at $1.8 \mathrm{~A}$ resolution. $\mathrm{J} \mathrm{Mol} \mathrm{Biol}$ 294, 1027-40.

41. Zakharov, S. D., Li, X., Red'ko, T. P. \& Dilley, R. A. (1996). Calcium binding to the subunit $c$ of $E$. coli ATP-synthase and possible functional implications in energy coupling. J Bioenerg Biomembr 28, 483-94.

42. Michiels, J., Xi, C., Verhaert, J. \& Vanderleyden, J. (2002). The functions of $\mathrm{Ca}(2+)$ in bacteria: a role for EF-hand proteins? Trends Microbiol 10, 87-93. 
43. Norris, V., Chen, M., Goldberg, M., Voskuil, J., McGurk, G. \& Holland, I. B. (1991). Calcium in bacteria: a solution to which problem? Mol Microbiol 5, 775-8.

44. Norris, V., Grant, S., Freestone, P., Canvin, J., Sheikh, F. N., Toth, I., Trinei, M., Modha, K. \& Norman, R. I. (1996). Calcium signalling in bacteria. J Bacteriol 178, 3677-82.

45. Onek, L. A. \& Smith, R. J. (1992). Calmodulin and calcium mediated regulation in prokaryotes. J Gen Microbiol 138, 1039-49.

46. Johnson, R. C. \& Gary, N. D. (1963). Nutrition of Leptospira Pomona. lii. Calcium, Magnesium, and Potassium Requirements. J Bacteriol 85, 9835.

47. Shenberg, E. (1967). Growth of pathogenic Leptospira in chemically defined media. J Bacteriol 93, 1598-606.

48. Cruz, W. T., Young, R., Chang, Y. F. \& Struck, D. K. (1990). Deletion analysis resolves cell-binding and lytic domains of the Pasteurella leukotoxin. Mol Microbiol 4, 1933-9.

49. Chang, Y. F., Shi, J., Ma, D. P., Shin, S. J. \& Lein, D. H. (1993). Molecular analysis of the Actinobacillus pleuropneumoniae RTX toxin-III gene cluster. DNA Cell Biol 12, 351-62.

50. Chenal, A., Guijarro, J. I., Raynal, B., Delepierre, M. \& Ladant, D. (2009). RTX Calcium Binding Motifs Are Intrinsically Disordered in the Absence of Calcium: IMPLICATION FOR PROTEIN SECRETION. J Biol Chem 284, 1781-9.

51. Jobby, M. K. \& Sharma, Y. (2005). Calcium-binding crystallins from Yersinia pestis. Characterization of two single betagamma-crystallin domains of a putative exported protein. J Biol Chem 280, 1209-16.

52. Lin, Y. P., Raman, R., Sharma, Y. \& Chang, Y. F. (2008). Calcium binds to leptospiral immunoglobulin-like protein, LigB, and modulates fibronectin binding. J Biol Chem 283, 25140-9.

53. Matsunaga, J., Barocchi, M. A., Croda, J., Young, T. A., Sanchez, Y., Siqueira, I., Bolin, C. A., Reis, M. G., Riley, L. W., Haake, D. A. \& Ko, A. I. (2003). Pathogenic Leptospira species express surface-exposed proteins belonging to the bacterial immunoglobulin superfamily. Mol Microbiol 49, 929-45.

54. Palaniappan, R. U., Chang, Y. F., Hassan, F., McDonough, S. P., Pough, M., Barr, S. C., Simpson, K. W., Mohammed, H. O., Shin, S., McDonough, P., Zuerner, R. L., Qu, J. \& Roe, B. (2004). Expression of leptospiral immunoglobulin-like protein by Leptospira interrogans and evaluation of its diagnostic potential in a kinetic ELISA. J Med Microbiol 53, 975-84.

55. Palaniappan, R. U., Chang, Y. F., Jusuf, S. S., Artiushin, S., Timoney, J. F., McDonough, S. P., Barr, S. C., Divers, T. J., Simpson, K. W., McDonough, P. L. \& Mohammed, H. O. (2002). Cloning and molecular characterization of an immunogenic LigA protein of Leptospira interrogans. Infect Immun 70, 5924-30.

56. Choy, H. A., Kelley, M. M., Chen, T. L., Moller, A. K., Matsunaga, J. \& Haake, D. A. (2007). Physiological osmotic induction of Leptospira interrogans adhesion: LigA and LigB bind extracellular matrix proteins and fibrinogen. Infect Immun 75, 2441-50. 
57. Lin, Y. P. \& Chang, Y. F. (2007). A domain of the Leptospira LigB contributes to high affinity binding of fibronectin. Biochem Biophys Res Commun 362, 443-8.

58. Lin, Y. P. \& Chang, Y. F. (2008). The C-terminal variable domain of LigB from Leptospira mediates binding to fibronectin. J Vet Sci 9, 133-44.

59. Ramos, C. R., Abreu, P. A., Nascimento, A. L. \& Ho, P. L. (2004). A highcopy T7 Escherichia coli expression vector for the production of recombinant proteins with a minimal N-terminal His-tagged fusion peptide. Braz J Med Biol Res 37, 1103-9.

60. Hauk, P., Guzzo, C.R., Ho, P.L., Farah, C.S. (2009). Crystallization and preliminary X-ray analysis of LipL32 from Leptospira interrogans sorovar Copenhageni. in press.

61. Bhandari, P. \& Gowrishankar, J. (1997). An Escherichia coli host strain useful for efficient overproduction of cloned gene products with $\mathrm{NaCl}$ as the inducer. J Bacteriol 179, 4403-6.

62. Ramos, C. R., Spisni, A., Oyama, S., Sforça, M.L., Roman-Ramos, H., Vilar, M.M., Alves, A.C., Figueredo, R.C.R., Tendler, M., Zanchin, N.I.T., Pertinhez, T.A., Ho, P.L. (2009). Stability improvement of the fatty acid binding protein Sm14 from S. mansoni by Cys replacement: Structural and functional characterization of a vaccine candidate. . Biochim. Biophys. Acta in press.

63. Pace, C. N., Scholtz, M. (1997). Measuring the conformational stability of a protein. In Protein Structure: A practical approach. (Creighton, T. E., ed.), pp. 299-321. IRL Press, New York.

64. Schneider, T. R. \& Sheldrick, G. M. (2002). Substructure solution with SHELXD. Acta Crystallogr D Biol Crystallogr 58, 1772-9.

65. La Fortelle, E. d., Bricogne, G. (1997). Maximum-likelihood heavy-atom parameter refinement for multiple isomorphous replacement and multiwavelength anomalous diffraction methods. Methods Enzymol. 276, 472-494.

66. Abrahams, J. P. \& Leslie, A. G. (1996). Methods used in the structure determination of bovine mitochondrial F1 ATPase. Acta Crystallogr D Biol Crystallogr 52, 30-42.

67. (1994). The CCP4 suite: programs for protein crystallography. Acta Crystallogr D Biol Crystallogr 50, 760-3.

68. Cowtan, K. (1994). An automated procedure for phase improvement by density modification. Joint CCP4 and ESF-EACBM Newsletter on Protein Crystallography 31, 34-38.

69. Perrakis, A., Morris, R. \& Lamzin, V. S. (1999). Automated protein model building combined with iterative structure refinement. Nat Struct Biol 6, 458-63.

70. Emsley, P. \& Cowtan, K. (2004). Coot: model-building tools for molecular graphics. Acta Crystallogr D Biol Crystallogr 60, 2126-32.

71. McCoy, A. J., Grosse-Kunstleve, R. W., Adams, P. D., Winn, M. D., Storoni, L. C., Read, R. J. (2007). Phaser crystallographic software. J. Appl. Cryst. 40, 658-674.

72. Murshudov, G. N., Vagin, A. A. \& Dodson, E. J. (1997). Refinement of macromolecular structures by the maximum-likelihood method. Acta Crystallogr D Biol Crystallogr 53, 240-55. 
73. Brunger, A. T., Adams, P. D., Clore, G. M., Delano, W. L., Gros, P., Grosse-Kunstleve, R. W., Jiang, J. S., Kuszewski, J., Nilges, M., Pannu, N. S., Read, R. J., Rice, L. M., Simonson, T. \& Warren, G. L. (1998). Crystallography \& NMR system: A new software suite for macromolecular structure determination. Acta Crystallogr D Biol Crystallogr 54, 905-21.

74. Painter, J. \& Merritt, E. A. (2006). Optimal description of a protein structure in terms of multiple groups undergoing TLS motion. Acta Crystallogr D Biol Crystallogr 62, 439-50.

75. Walker, J. R., Cuerrier, D., Ravulapalli, R., Weigelt, J., Arrowsmith, C.H., Edwards, A.M., Bochkarev, A., Dhe-Paganon, S. . (To be Published ). Structure of the C2 Domain of Human Calpain-7.

76. Donadini, R., Liew, C. W., Kwan, A. H., Mackay, J. P. \& Fields, B. A. (2004). Crystal and solution structures of a superantigen from Yersinia pseudotuberculosis reveal a jelly-roll fold. Structure 12, 145-56.

77. Holyoak, T., Kettner, C. A., Petsko, G. A., Fuller, R. S. \& Ringe, D. (2004). Structural basis for differences in substrate selectivity in Kex2 and furin protein convertases. Biochemistry 43, 2412-21.

78. DeLano, W. L. (2002). The PyMOL molecular graphics system. http://www.pymol.org.

79. Larkin, M. A., Blackshields, G., Brown, N. P., Chenna, R., McGettigan, P. A., McWilliam, H., Valentin, F., Wallace, I. M., Wilm, A., Lopez, R., Thompson, J. D., Gibson, T. J. \& Higgins, D. G. (2007). Clustal W and Clustal X version 2.0. Bioinformatics 23, 2947-8. 


\section{TABLES}

Table 1: Refinement statistics for $\mathrm{P} \mathbf{3}_{2} 21$ LipL32 ${ }_{21-272}$ crystal structure.

\begin{tabular}{|c|c|}
\hline Refinement $(35.0-2.25 \AA)$ & \\
\hline $\begin{array}{l}\text { No. of molecules/A.U. } \\
\text { residues/chain } \\
\text { waters }\end{array}$ & $\begin{array}{c}2 \\
254 \\
295\end{array}$ \\
\hline $\mathrm{R}_{\text {factor }}^{\top}$ & 0.184 \\
\hline$R_{\text {free }}{ }^{\top}$ & 0.227 \\
\hline $\begin{array}{l}\text { R.m.s.d. } \\
\text { bond lengths }(\AA) \\
\text { bond angles }\left({ }^{\circ}\right)\end{array}$ & $\begin{array}{l}0.017 \\
1.582\end{array}$ \\
\hline $\begin{array}{l}\% \text { of residues in Ramachandran regions: } \\
\text { most favored } \\
\text { additional allowed } \\
\text { generously allowed } \\
\text { disallowed }\end{array}$ & $\begin{array}{l}91.5 \\
8.5 \\
0.0 \\
0.0\end{array}$ \\
\hline
\end{tabular}

${ }^{\top} \mathbf{R}_{\text {factor }}=\Sigma\left|F_{O}-F_{C}\right| / \Sigma F_{O}$

$5 \%$ of the data were excluded for $\mathrm{R}_{\text {free }}$ calculation. 
Table 2. Proteins structurally similar to LipL32 $21-272$ identified using the Dali server ${ }^{21}$.

\begin{tabular}{|c|c|c|c|c|}
\hline Z-score & RMSD (A) & PDB & Protein & Organism \\
\hline $8.8-6.7$ & $3.2-4.9$ & $\begin{array}{l}\text { 2QFE, 1KFU, 1QXP, 1U5I, 1DF0, } \\
\text { 1KFX, 3BOW, 3DFO, 1KFX, }\end{array}$ & calpain-7, calpain-2 & Homo sapiens, Rattus norvegicus \\
\hline 6.3 & 3.1 & 1PM4 & Y.p.-derived mitogen a & Yersinia pseudotuberculosis \\
\hline 5.4 & 2.4 & 2QUO & C. perfringens enterotoxin & Clostridium perfringens \\
\hline $6.3-5.8$ & 2.4 & 1NQJ, 1NQD, $2 \mathrm{O} 8 \mathrm{O}$ & class 1 collagenase & Clostridium histolyticum \\
\hline $5.9-5.0$ & $3.2-4.0$ & 1F15, 1LAJ, 1ZA7, 1GFF, 1WCD & $\begin{array}{l}\text { Icosahedral } \\
\text { coat proteins }\end{array}$ & $\begin{array}{l}\text { Cucumber mosaic vírus, Tomato asp. virus, } \\
\text { Cowpea c. m. virus, Bacteriophage g4, } \\
\text { Avian inf. B. d. virus }\end{array}$ \\
\hline $5.3-5.2$ & 4.2 & 2ID4, 1R64, 10T5 & kexin2 peptidase & Saccharomyces cerevisiae \\
\hline
\end{tabular}

* All Dali server hits with Z-score > 5.0 are listed. 
Figure 1a

Click here to download high resolution image

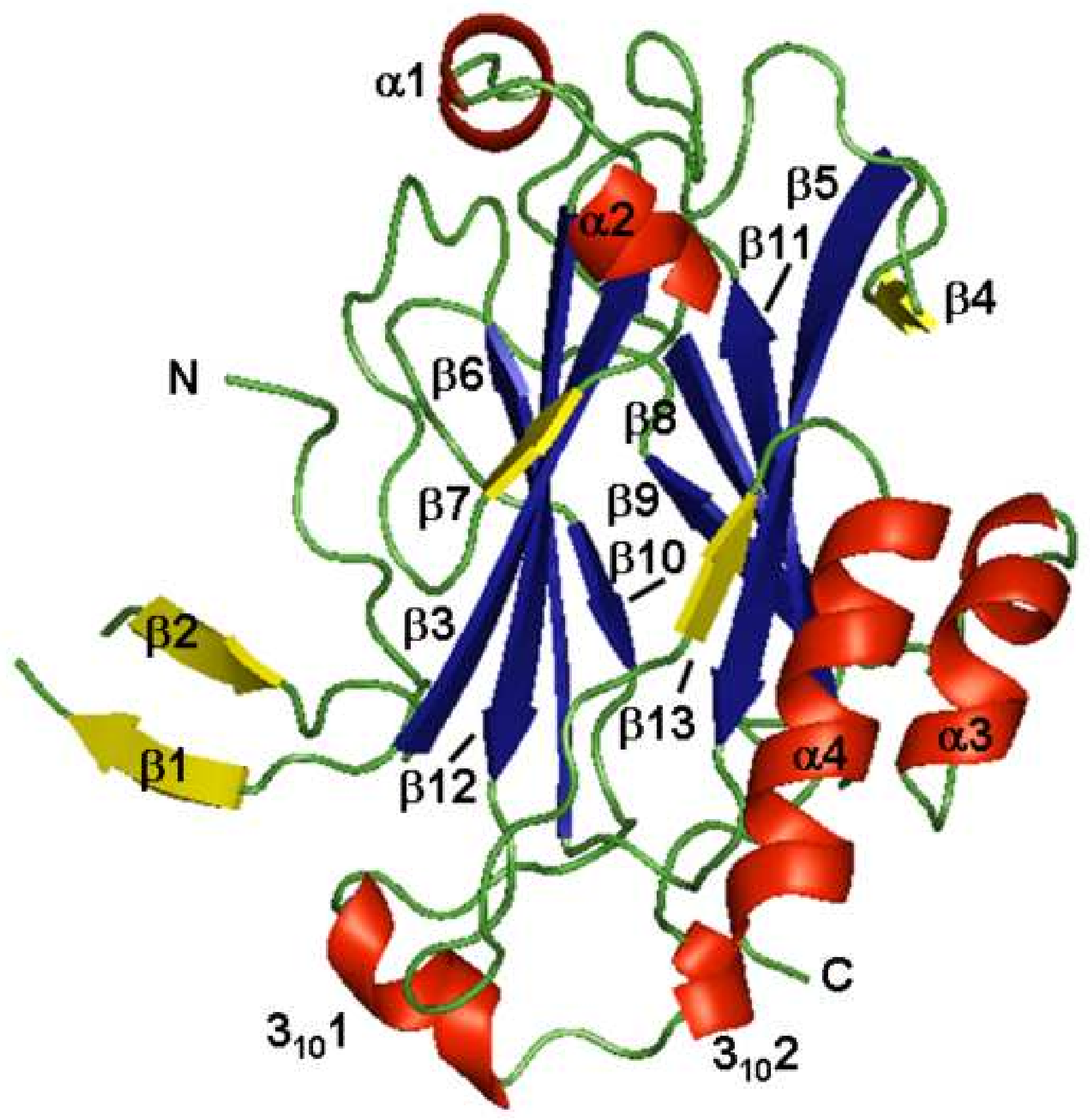




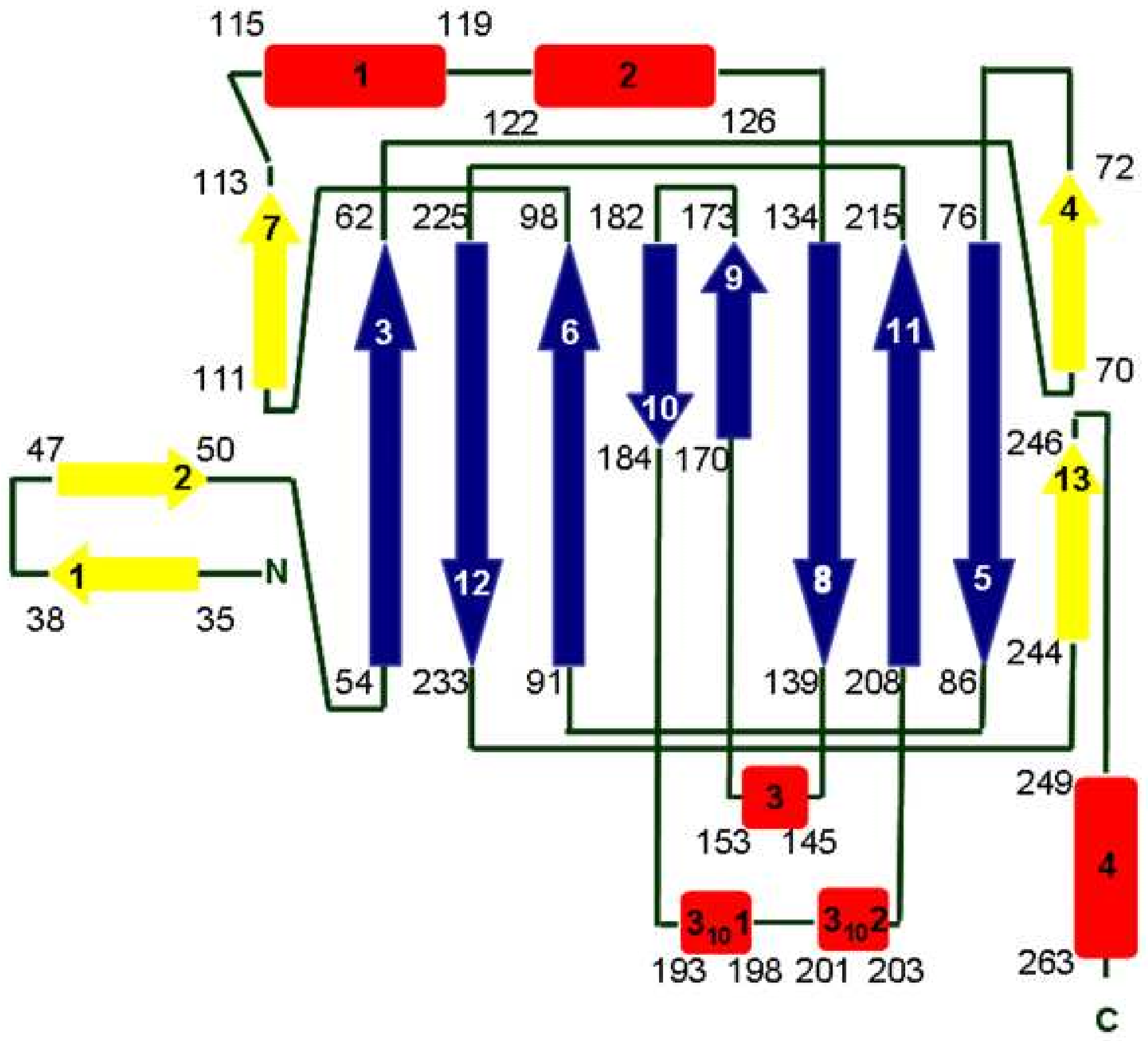


Click here to download high resolution image
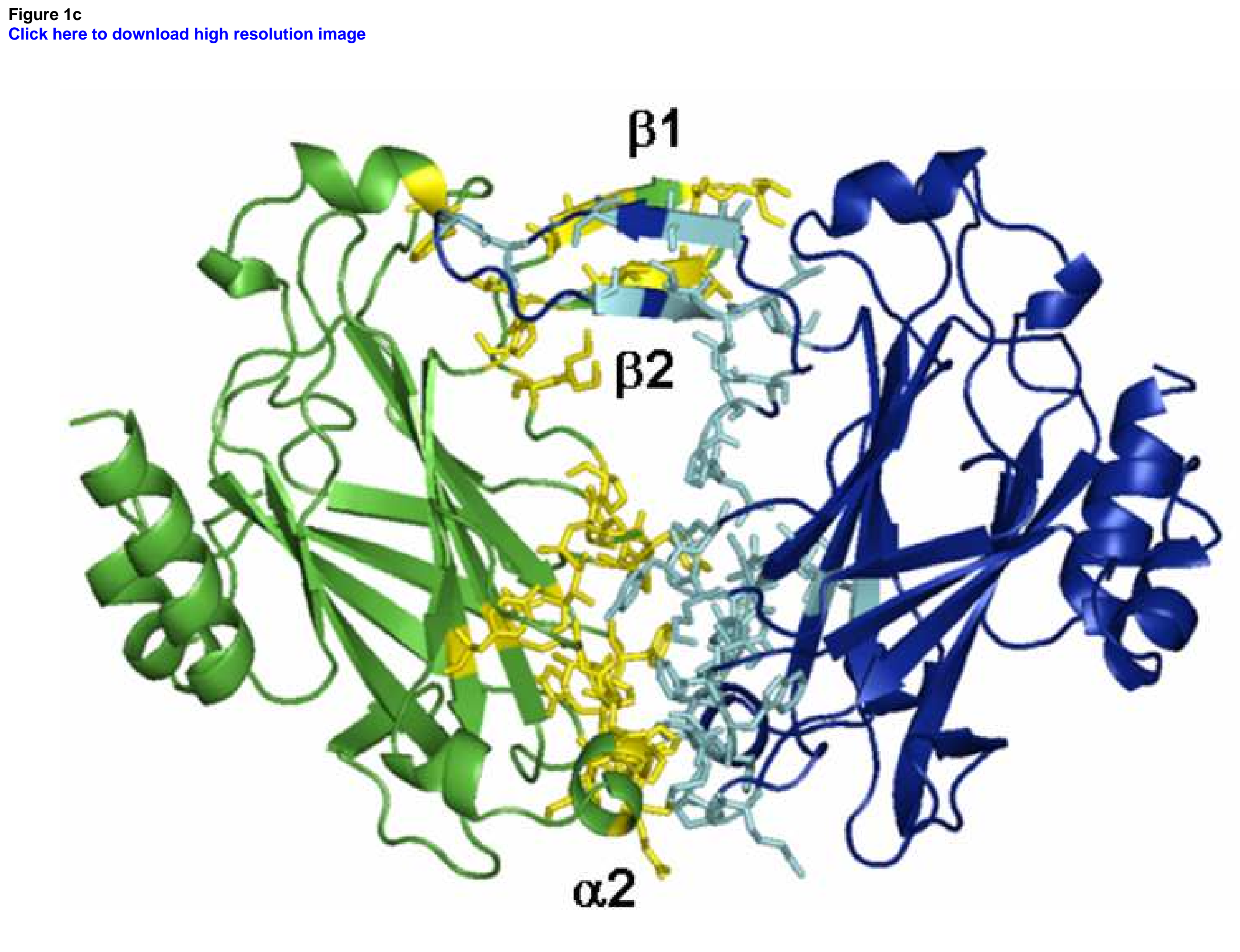

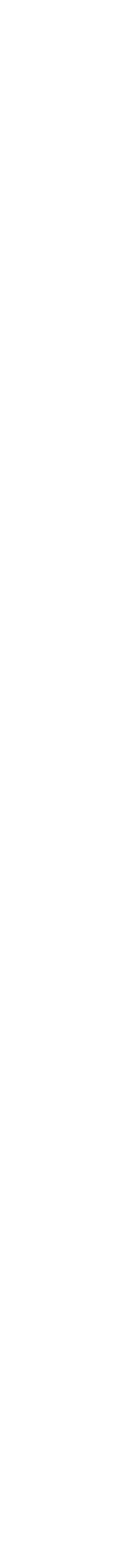
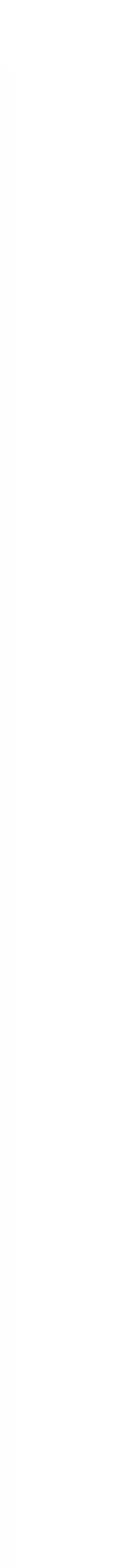

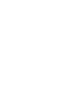


Click here to download high resolution image

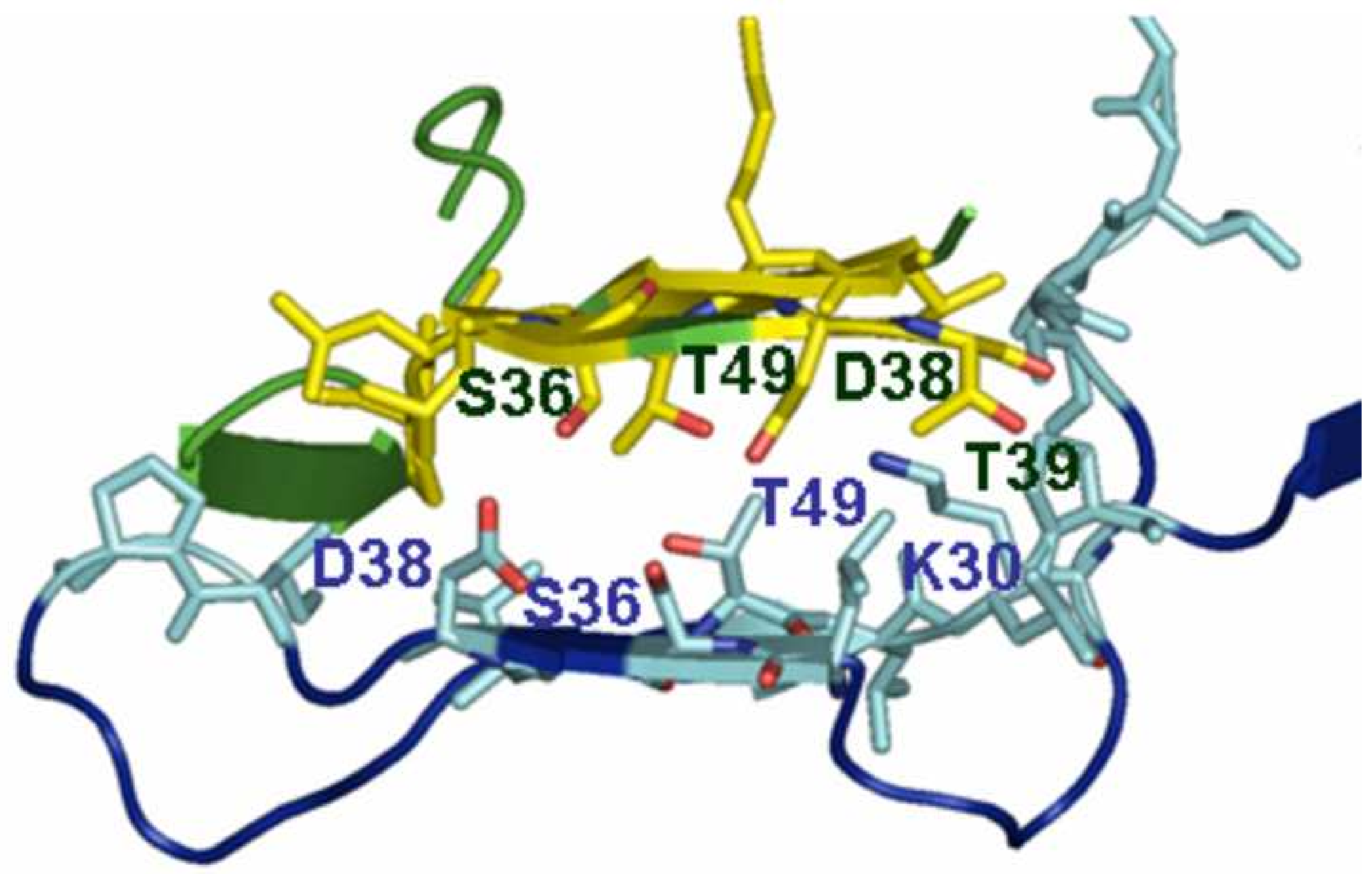


Click here to download high resolution image

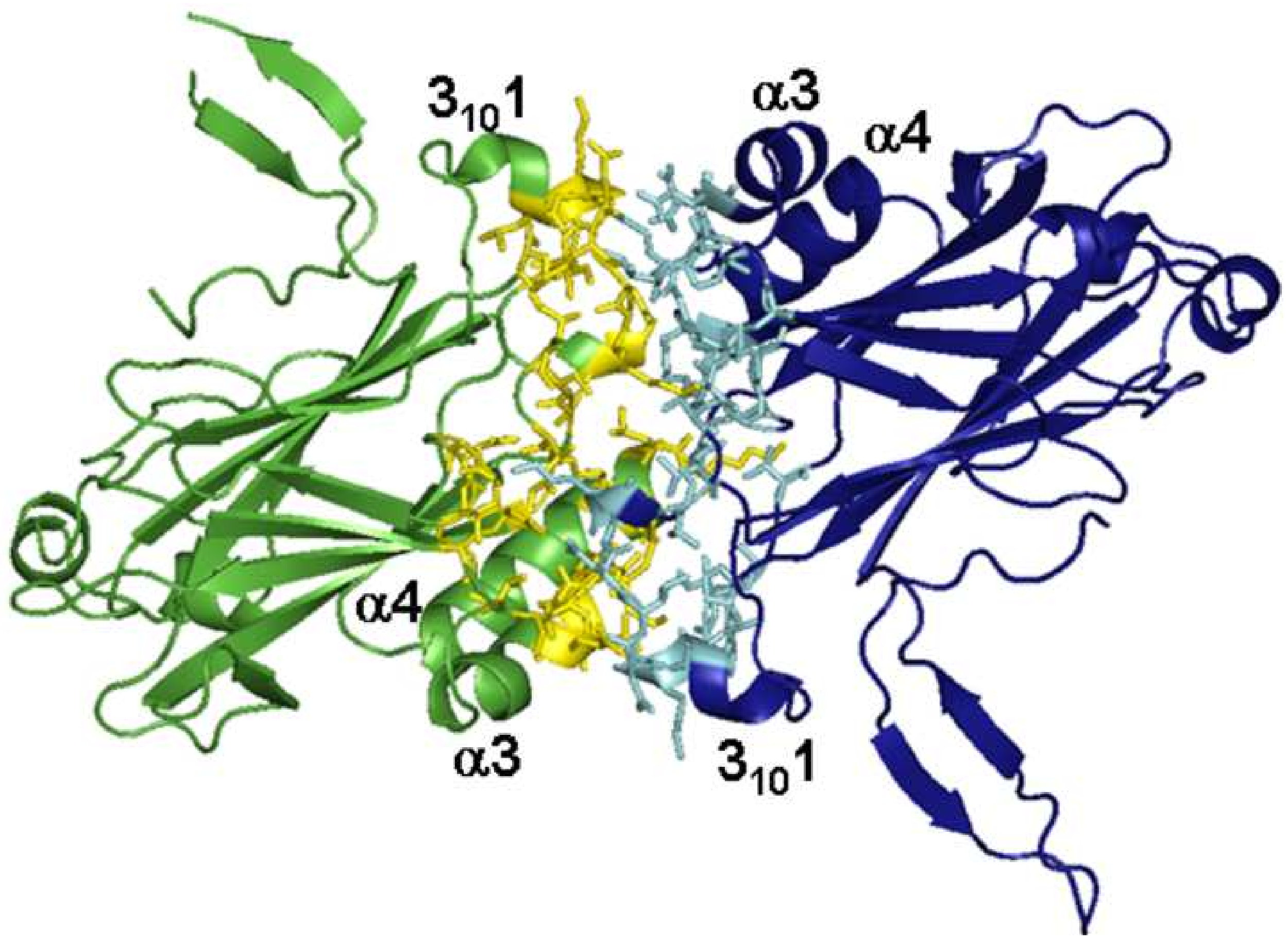


Click here to download high resolution image

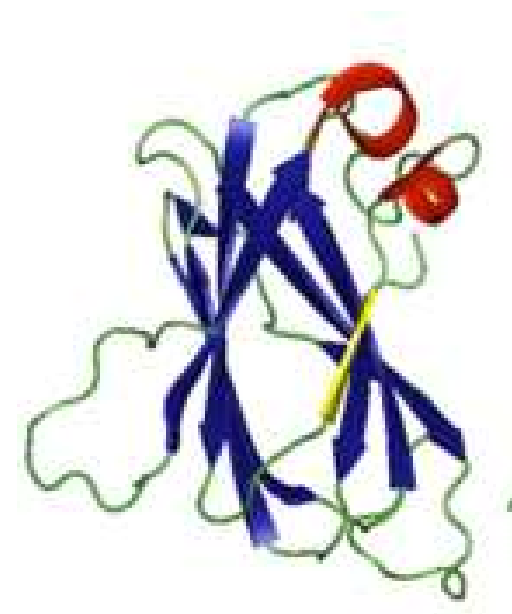

2QFE

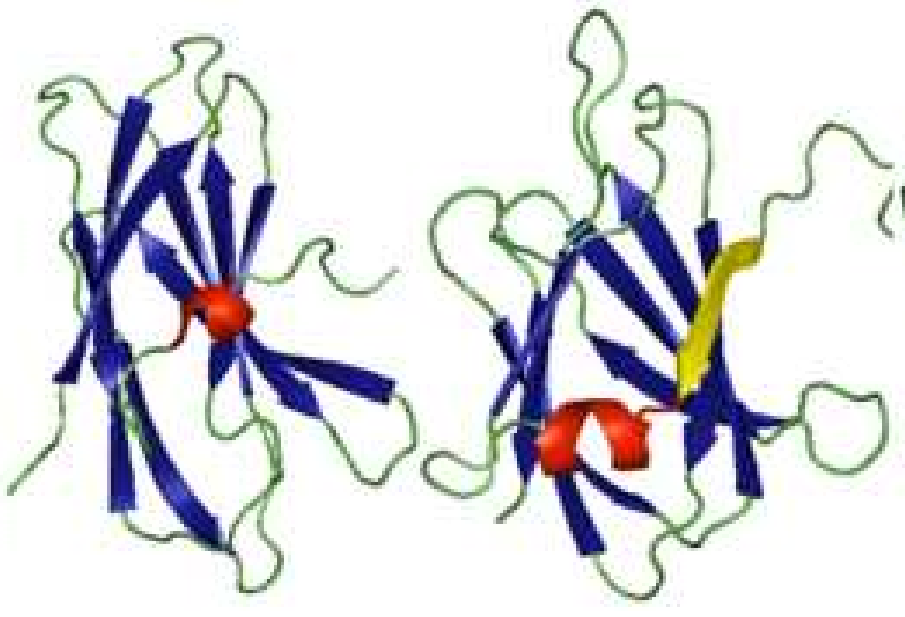

1PM4

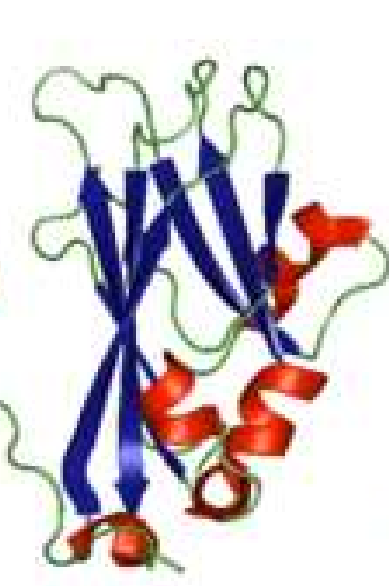

1ZA7

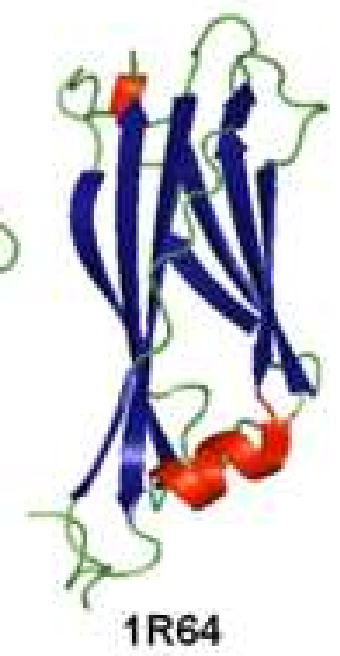


Figure 2

Click here to download high resolution image

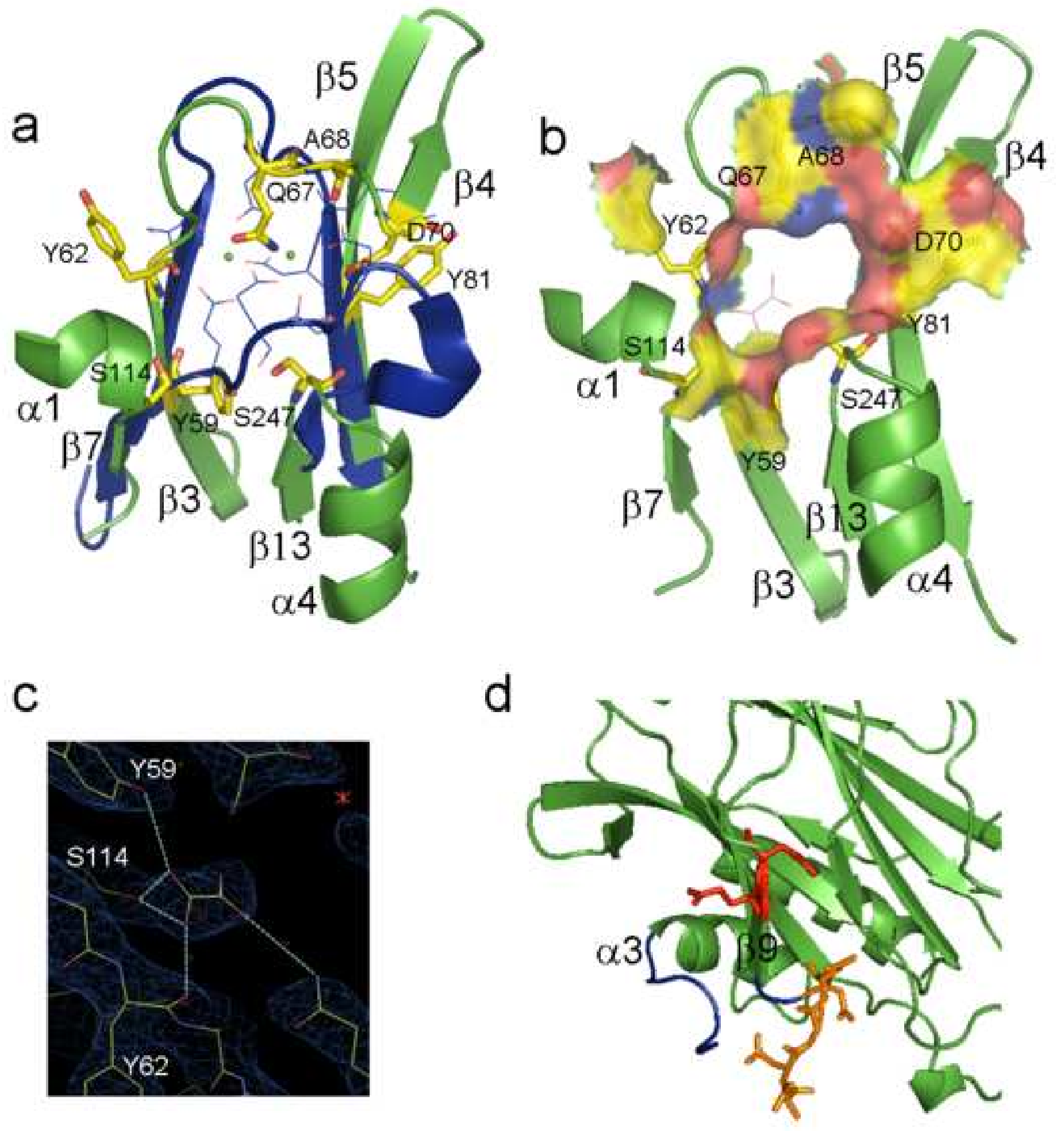




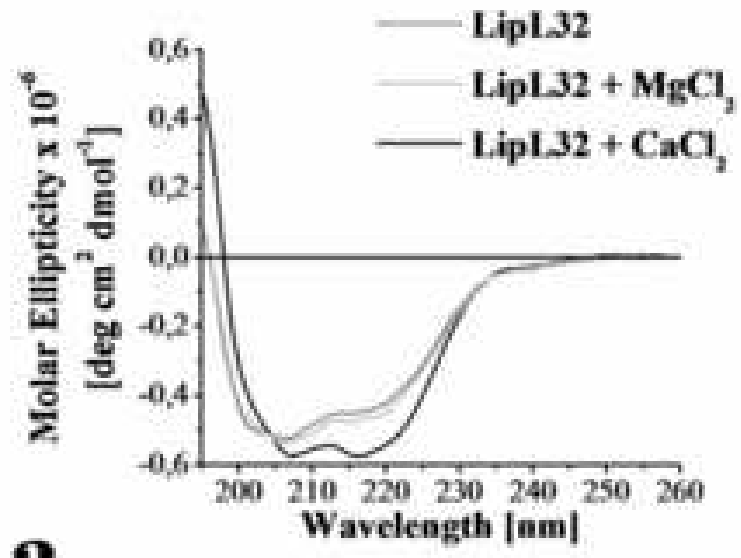

a
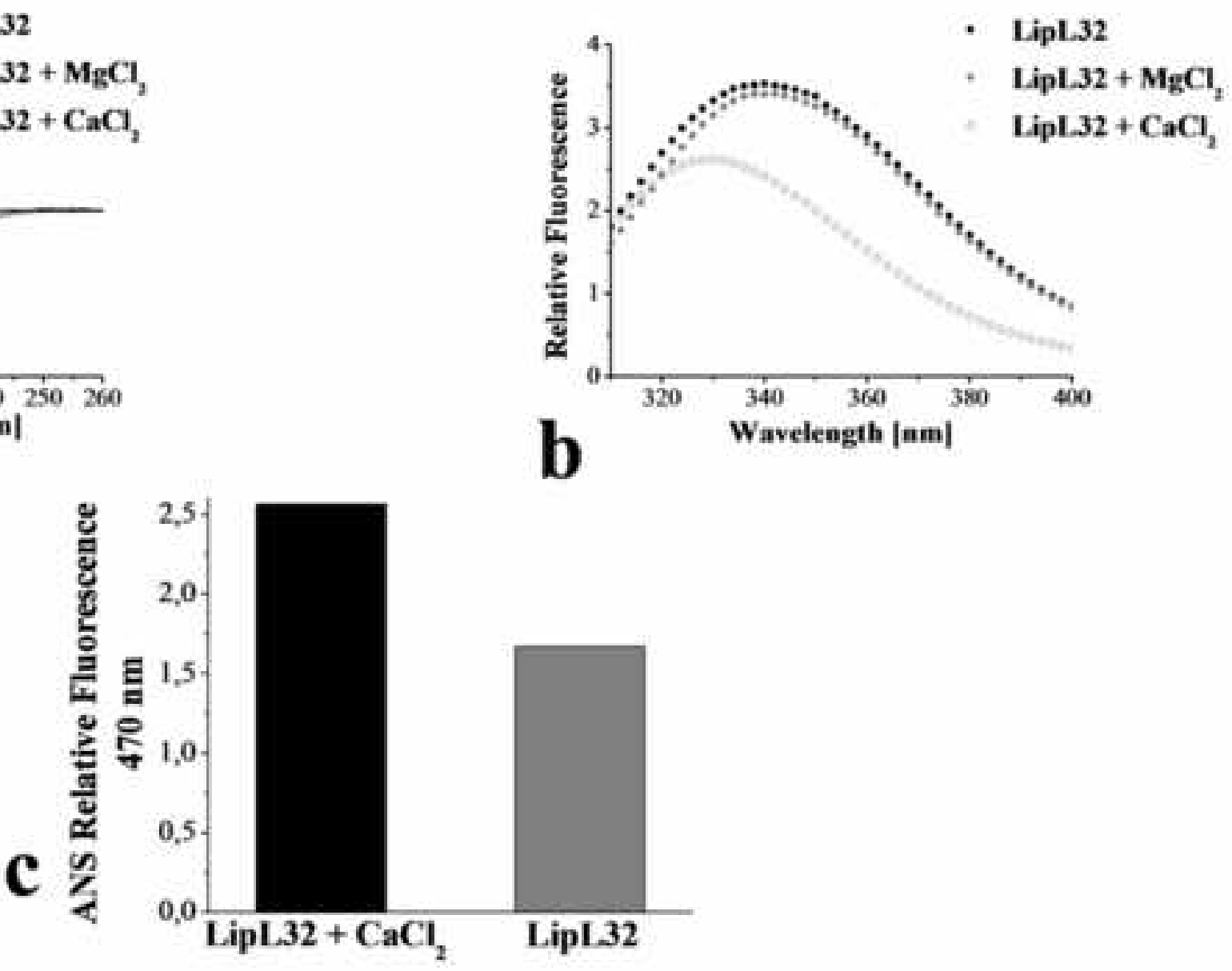

LipL.32

Lipl.32 $+\mathrm{MgCl}_{2}$ Lipl.32 + $\mathrm{CaCl}_{2}$

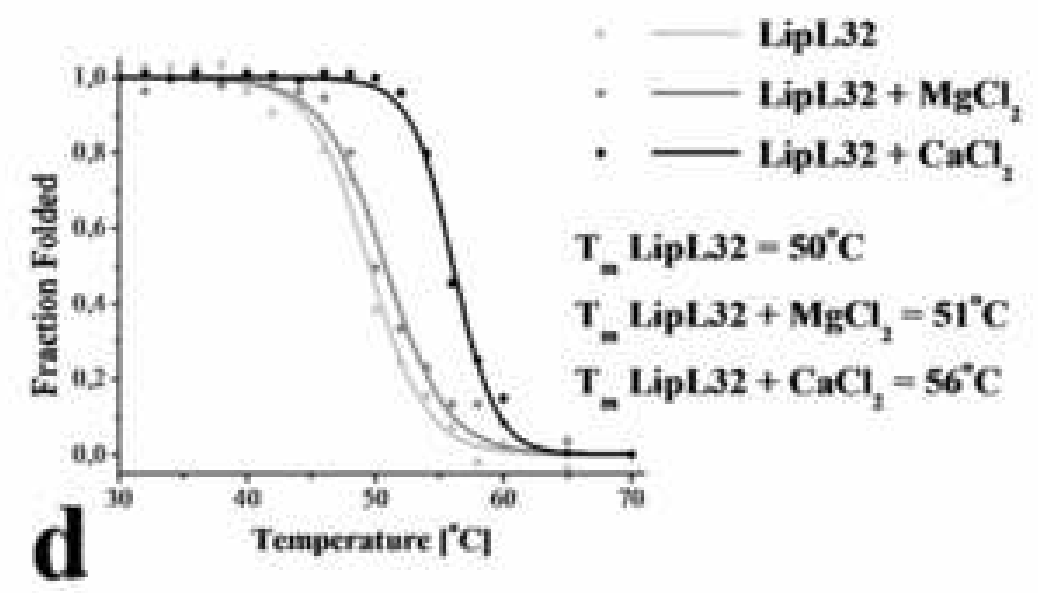

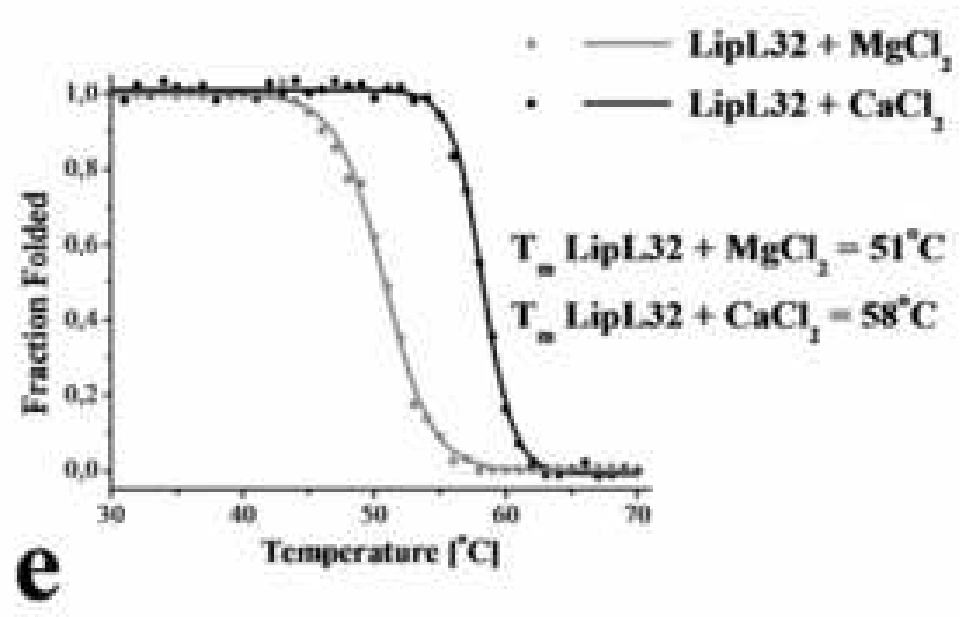




\section{Figure 4}

Click here to download high resolution image
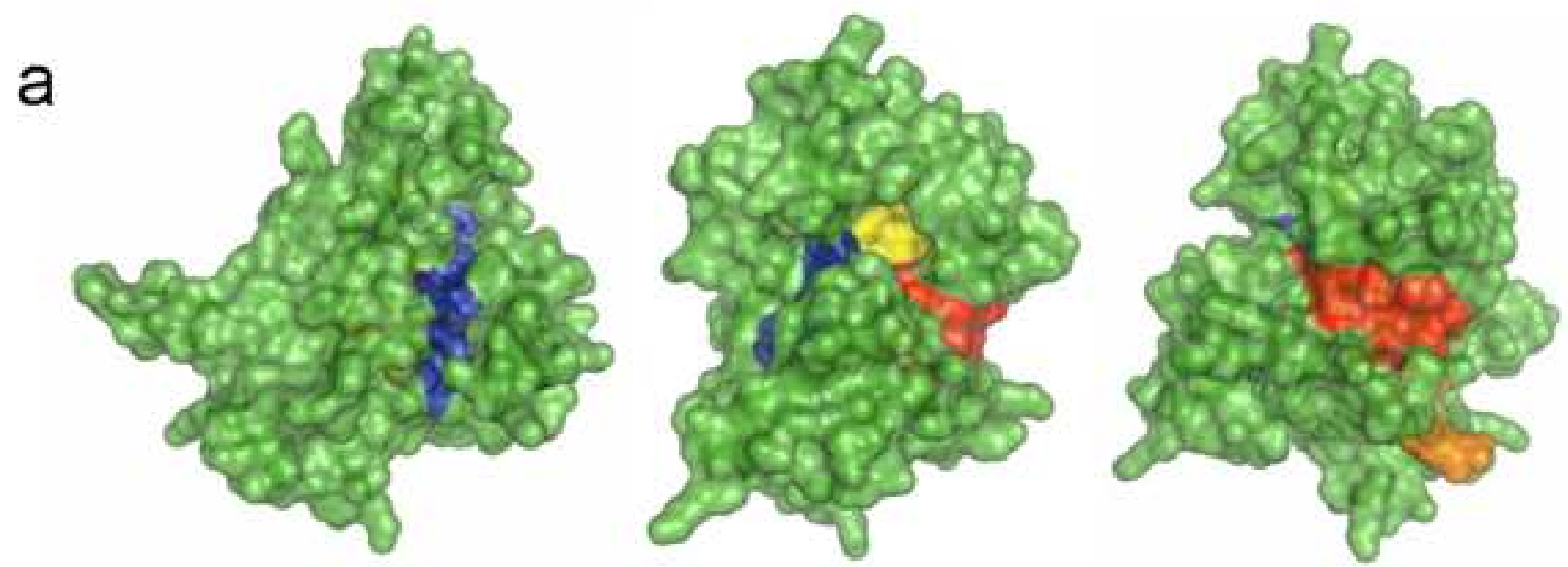

b

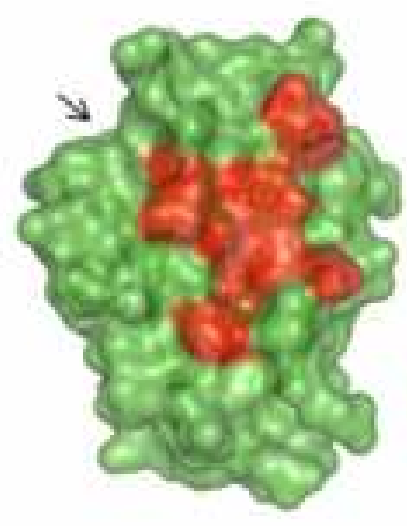




\section{Click here to download high resolution image}

Leptospira intertogans Fseudoaltercecass tunicata Moritella

eubacteriun 9049

Leptoapira Interrogans Pseudoaleercacnas tunicata Moritella

eubacteriun acb49

Leptoapira interrogatia Preudoaltercoconas tunicata Motitella

eubacteriun sc84?

Leptospira interrogans Paeudoaltercencnas tunicata Moritella

eubacteriun sca49

Leptospira intertogani Pseudoaltetonchas tunicata Moritella

eubacteriun scte49

Leptospite interrogans Pseudoaltercacnas tunicata Woritella

eubacterfun $\operatorname{scb} 49$

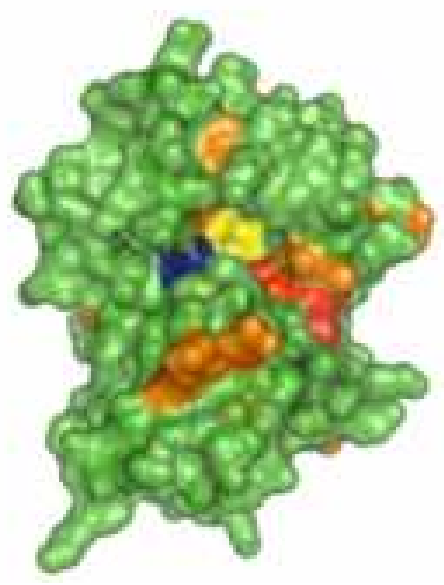

B1

102

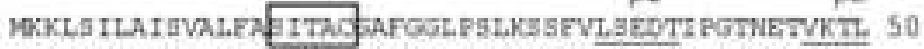

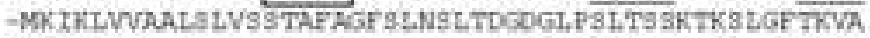
MKKGLATKLLFLLATVTLAGC-.......-MSTGPHLKS SNKES IAGMEVR

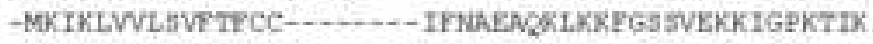
+ $1 .+2 .+$ p3 B4 is ק6 LPYGUVINYYGVK PGQAEDGLVDGHKKAYYLYVWIEAVIAESGVFAIJE 100

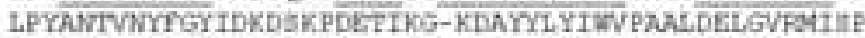

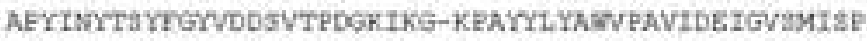
VFYTDVIIYLGYATGNE-DAVVDG-KKFIYIYIWVPAVATELGVFLSE

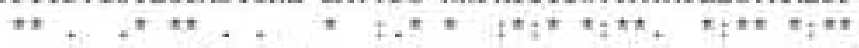

TGEIGEEGDGDLVDAFKAUTPEEKIVEHEDTWIRVEFMUAMPDOIAK 150 VGDLAKPEKSDEVQRGEADKLKADK-CKKEDTVIFVEFMDVISPEKIHD

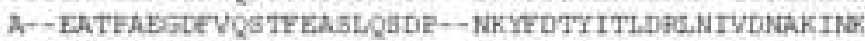

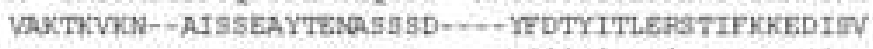

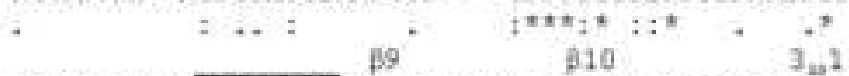

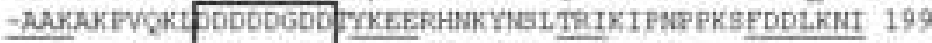

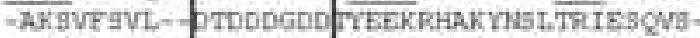

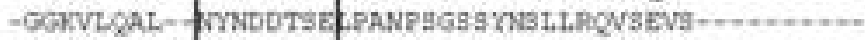

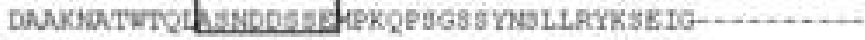

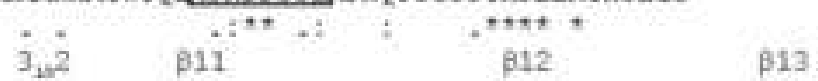

DTKKLLVFSLYRISFTTK PGEVKGSFVASVGLIY PEGIPGVSELIHSME 249

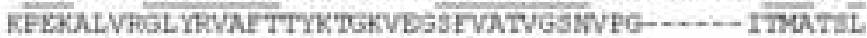

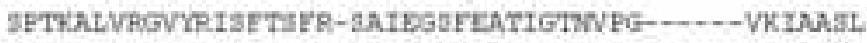
BETKALTAGLYRIGPTYKTGEVKGTYLAEVMRPVKLEG-..-VVMAKTI

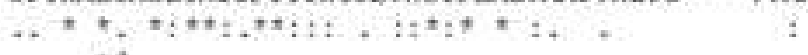
$\alpha 4$

ELCKCAIAREมLKKAMSDATK 272

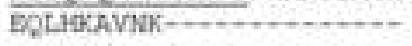

EET HELVNWKEG …...........

EtLkKEL_.................

$* * * ; *$

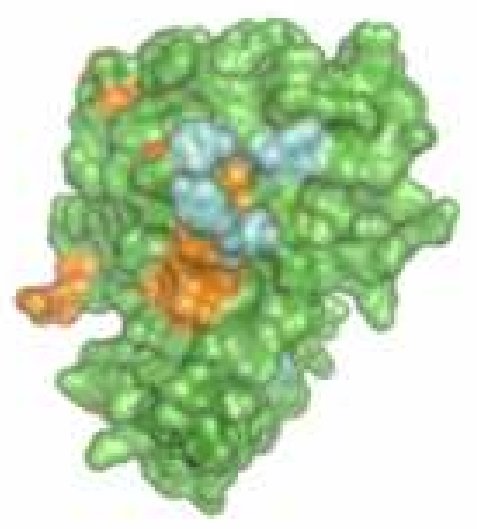

